\title{
Religiøst medborgerskap
}

Funksjonshemming, likeverd og menneskesyn

Inger Marie Lid og Anna Rebecca Solevåg (red.)

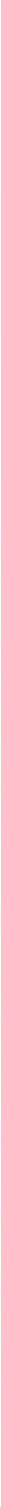


Religiøst medborgerskap 

Inger Marie Lid og Anna Rebecca Solevåg (red.)

\section{Religiøst \\ medborgerskap}

FUNKSJONSHEMMING, LIKEVERD OG MENNESKESYN 
(C) Inger Marie Lid, Anna Rebecca Solevåg, Knut Alfsvåg, Leonora Onarheim Bergsjø, Therese M. I. Bjørnaas, Anita Gjermestad, Gyrid Gunnes, Hans Morten Haugen, Gunnar Heiene, Kari Jordheim, Dmitry Lukash, Terese Bue Kessel og Nora Simonhjell 2020.

Dette verket omfattes av bestemmelsene i Lov om opphavsretten til åndsverk m.v. av 1961. Verket utgis Open Access under betingelsene i Creative Commons-lisensen CC BY-NC-ND 4.o. Denne lisensen lar andre kopiere, distribuere og spre verket i hvilket som helst medium eller format, under forutsetning av at det oppgis korrekt kreditering og lenke til lisens. Dette kan gjøres på enhver rimelig måte, men uten at det kan forstås slik at lisensgiver bifaller deg eller din bruk av verket. Materialet kan ikke benyttes til kommersielle formål. Dersom du remixer, bearbeider eller bygger på materialet, kan du ikke distribuere det endrede materialet. Lisensvilkår: https://creativecommons.org/ licenses/by-nc-nd/4.o/deed.no

Boka er utviklet med støtte fra Størst av alt - trosopplæring i Den norske kirke.

ISBN Trykt bok: 978-82-02-68108-1

ISBN PDF: 978-82-02-63053-9

ISBN EPUB: 978-82-02-68105-0

ISBN HTML: 978-82-02-68106-7

ISBN XML: $978-82-02-68107-4$

DOI: https://doi.org/10.23865/noasp.10o

Dette er en fagfellevurdert antologi.

Omslagsdesign: Cappelen Damm AS

Omslagsillustrasjon: Gry Segerblad

Cappelen Damm Akademisk/NOASP

noasp@cappelendamm.no 


\section{Innhold}

Innledning: Religiøst medborgerskap.............................................................. 7

Kapittel 1 Utviklingshemmedes rett til religionsutøvelse i Norge .................29 Dmitry Lukash

Kapittel 2 Inkludering og tilrettelegging i Den norske kirkes trosopplæring .49 Inger Marie Lid

Kapittel 3 Når det å være til er nok: Et profesjonsetisk blikk på menneskeverd og sårbarhet. .69 Anita Gjermestad

Kapittel 4 Taktil teologi: Om kirkerom og mangfoldige estetiske uttrykk .....89 Leonora Onarheim Bergsjø

Kapittel 5 Diakoni i et funksjonshemmingsperspektiv: Tilværelsens gave og Liv i mangfoldig fellesskap. 107 Kari Jordheim

Kapittel 6 Sårbarhet, mangfold og menneskerettigheter 129 Hans Morten Haugen

Kapittel 7 Funksjonshemming, bioteknologi og menneskesyn: Utfordringer for kristen etikk. 153 Gunnar Heiene

Kapittel $8 \AA$ A fortelje eller bli fortalt: Ein analyse av Olaug Nilssens Tung tids tale (2017) 175 Nora Simonhjell

Kapittel 9 Infertilitet som sosial og kulturell funksjonshemming: Et perspektiv fra Kamerun 193 Terese Bue Kessel 
Kapittel 10 Døve, blinde og lamme i Guds rike? Helse og frelse i

Det nye testamentet.

Anna Rebecca Solevåg

Kapittel 11 Helbredelsesforkynnelse og kristen tro

Knut Alfsvåg

Kapittel 12 Den desentrerte kirke: Et bidrag til disability-ekklesiologien .....249

Gyrid Gunnes

Kapittel 13 Imago Dei og kroppsliggjort væren:

En funksjonshemmingsteologi i lys av Thomas Aquinas 269

Therese Marie Ignacio Bjørnaas

Om forfatterne 


\title{
Innledning: Religiøst medborgerskap
}

\author{
Inger Marie Lid og Anna Rebecca Solevåg \\ VID vitenskapelige høgskole
}

\begin{abstract}
The introductory chapter gives an introduction to various aspects of religious citizenship. Drawing on an understanding of citizenship based on human rights, we present the UN documents and conventions that promote rights for persons with disabilities. We also present the most basic models of disability theorized within Disability Studies. Turning to the religious aspects of citizenship, we discuss important contributions from disability theology such as diversity as a gift given by God in creation, and images of God as a vulnerable, even disabled God through Christ's incarnation. The World Council of Churches has contributed to a rights-based theological understanding of disability through the documents A Church of All and for All and The Gift of Being. These documents are introduced. The chapter also discusses diaconal perspectives on disability. We argue that the former diaconal practice of segregation, and the distinction between 'able-bodied' helper and disabled recipients of diakonia is gradually being replaced. Instead we see the emergence of a disability diakonia where vulnerability is reconfigured as something that affects all of humanity, and where communities of mutual support and generosity become the norm. Finally we discuss the ethical aspects of religious citizenship, arguing that the various professions involved in securing religious citizenship for all (e.g. health workers, social workers, ministers, deacons and religious educators), need to reflect on their professional praxis in order to have a human rights based approach that secures equality.
\end{abstract}

Keywords: religious citizenship, CRPD, models of disability, World Council of Churches, disability theology, diakonia, professional praxis

\section{Innledning}

Denne antologien tar som utgangspunkt at funksjonsnedsettelse og funksjonshemming er meningsfulle menneskelige erfaringer som det er viktig å tenke kritisk gjennom også i en norsk kontekst. Medborgerskap - det at alle borgere skal ha like vilkår og muligheter for deltakelse i et samfunn er relevant også for religion, teologi og diakoni. Religiøst medborgerskap

Sitering av denne artikkelen: Lid, I. M. \& Solevåg, A. R. (2020). Innledning: Religiøst medborgerskap. I I. M. Lid \& A. R. Solevåg (Red.), Religiøst medborgerskap: Funksjonshemming, likeverd og menneskesyn (s. 7-27). Oslo: Cappelen Damm Akademisk. https://doi.org/10.23865/noasp.10o.cho

Lisens: CC BY-NC-ND 4.0. 
innbefatter blant annet muligheter til å kunne velge religiøs deltakelse og være religiøst aktiv, for eksempel gjennom tilknytning og sosial deltakelse, yrkesutøvelse og frivillig aktivitet.

Siden 2014 har VID vitenskapelige høgskole hatt søkelys på tverrfaglig utvikling av feltet funksjonshemming og religion, blant annet gjennom å etablere et nettverk for teologi og funksjonshemming som arrangerer årlige seminarer med bidrag fra både forskning og praksis. Som et resultat av denne faglige og strategiske satsingen kommer de fleste kapitlene i denne antologien fra forskere ved VID vitenskapelige høgskole. Artikkelforfatterne representerer ulike fagtradisjoner, som teologi, diakoni, vernepleie, religionssosiologi, litteraturvitenskap og statsvitenskap. I tillegg har antologien kapitler skrevet av forfattere fra Universitetet i Agder, MF vitenskapelig høyskole, Dronning Mauds Minne Høgskole og Universitetet i Oslo. Bidragene belyser sammenhenger mellom menneskesyn, etikk, deltakelse og rettigheter.

Temaet er relevant for både forskning, undervisning og praksis. Målgrupper for antologien er derfor studenter, forskere og ansatte som arbeider i helse- og velferd og i religiøse, kirkelige eller diakonale kontekster. Vi tenker at den faglige samtalen om religiøst medborgerskap ikke bare må gå på tvers av de ulike fagdisiplinene, men også minske gapet mellom akademia og praksisfeltet.

\section{Menneskerettigheter og medborgerskap}

Bokens ulike kapitler fortolker variasjoner i funksjonsevne og funksjonshemming i lys av et menneskerettsperspektiv. Menneskerettighetsperspektivet handler om at den enkelte skal kunne delta på like vilkår som borger i et samfunn. Dette kan også kalles «å være medborger» og «å praktisere medborgerskap». Det å kunne ha likeverdige muligheter til å delta som borger på ulike samfunnsarenaer er relatert til de sosiale, samfunnsmessige og relasjonelle aspektene ved variasjoner i funksjonsevne. Medborgerskap handler derfor om å være og kunne bidra som en borger i et samfunn. Det er med andre ord en praktisk handlingsorientert dimensjon ved medborgerskapet (Isin \& Nielsen, 2008). 
I denne boken er vi særlig opptatt av å skape bevissthet om religiøst medborgerskap og dermed av muligheten til å ha et trosliv og kunne delta i trosopplæring og religiøse fellesskap. Det å kunne være et religiøst subjekt og delta i religiøse fellesskap har å gjøre med tilrettelegging for deltakelse, både på konkret nivå og på et overordnet politisk nivå. På dette området er det, som vi skal se i bokens kapitler, noen ganger et gap mellom de intensjoner og handlingsplaner som finnes, og det som foregår i praksis.

FN har i lang tid behandlet variasjoner i funksjonsevne og funksjonshemming som et menneskerettighetstema. 1981 var FNs år for funksjonshemmede. Dette året ble etterfulgt av FNs tiår for funksjonshemmede. FNs standardregler for like muligheter for mennesker med funksjonshemming har religiøs deltakelse med i regel nummer 12 (Sosial- og helsedepartementet, 2001). Standardreglene er blitt brukt i Norge for å utforme et grunnlag for en inkluderende praksis. Imidlertid står disse standardreglene svakere politisk enn en konvensjon. I 2008 trådte FNs Konvensjon om rettighetene til personer med nedsatt funksjonsevne (CRPD) i kraft (Barne-, likestillings- og inkluderingsdepartementet, 2013). I 2020 har 177 land ratifisert konvensjonen. Norge signerte konvensjonen i 2007 og ratifiserte den i 2013. Gjennom ratifikasjonen er Norge part til konvensjonen og forpliktet på å følge de regler og retningslinjer konvensjonen gir. I denne antologien vil vi bruke den engelske forkortelsen CRPD eller omtale den som «(FN-)konvensjonen».

Religiøs deltakelse er ikke nevnt i konvensjonen, men innbefattes i FNs konvensjon om sivile og politiske rettigheter. Artikkel 18 i denne konvensjonen fastslår retten til religionsfrihet (Justis- og beredskapsdepartementet, 2014). Retten til religiøs deltakelse dekkes også implisitt av artikler i CRPD. Artikkel 24, som handler om opplæring, og artikkel 30, som handler om kultur og fritid, er begge relevante for å sikre det vi omtaler som religiøst medborgerskap. Trosopplæring er for eksempel en form for opplæring, og religiøse deltakelse faller inn under kultur- og fritidsaktiviteter. CRPD er også relevant for kirkelige og andre religiøse fellesskap som aktører i offentligheten.

De statene som har ratifisert konvensjonen, plikter å sikre at personer med funksjonsnedsettelse har samme muligheter som alle landets 
borgere. Likeverd, likestilling og tilgjengelighet er gjennomgående temaer. FN-konvensjonen gir ikke nye rettigheter, men slår fast at de menneskerettighetene som gjelder, også gjelder for personer med funksjonsnedsettelse. Likeverdig tilgjengelighet er konvensjonens nøkkelbegrep. Det er for eksempel ikke tilstrekkelig å ha rett til skolegang, en har også rett til å komme til, og til å kunne bruke skolen, både som elev, som lærer og som foresatt. Tilgjengelighet blir dermed en forutsetning for at den enkelte skal kunne benytte seg av sine rettigheter (Lid, 2020; Barne-, likestillings- og inkluderingsdepartementet, 2013, art. 3 og 9). Konvensjonen er et omfattende dokument som berører alle viktige samfunnsarenaer som utdanning, kultur, arbeid, helse, familie og lokalsamfunn. Den er en milepæl for anerkjennelsen av funksjonshemming som et menneskerettslig tema.

CRPD setter diskriminering på grunnlag av funksjonsevne tydelig inn i et menneskerettighetsperspektiv og klargjør at funksjonshemming handler om menneskerettigheter. Konvensjonens formål er å fremme respekten for personer med funksjonsnedsettelse og å fremme likeverd i praksis. Ifølge konvensjonen oppstår funksjonshemming i konkrete situasjoner i samspill mellom menneske og miljø. Funksjonsnedsettelse tilhører det menneskelig mangfold og omfatter fysiske, mentale, intellektuelle og sansemessige forhold. Konvensjonen fremmer dermed et anerkjennende syn på variasjoner i funksjonsevne som del av menneskelig mangfold, og den etablerer en internasjonal diskurs som anerkjenner funksjonsevne som diskrimineringsgrunnlag på linje med for eksempel kjønn, kultur, etnisitet og seksuell orientering (Barne-, likestillings- og inkluderingsdepartementet, 2013; Bickenbach, 2012; Lid, 2014). Denne forståelsen vil også prege bokens kapitler.

\section{Tverrfaglig funksjonshemmingsforskning}

Det er flere måter å forstå funksjonshemming på, og vi vil her gi en kortfattet redegjørelse for de viktigste teoretiske forståelsesmodellene. Variasjoner i funksjonsevne og funksjonsnedsettelse settes ofte i forbindelse med sykdom. Dette stemmer i noen sammenhenger; en person kan få en sykdomsdiagnose som fører til funksjonsnedsettelse - og til 
funksjonshemming - i en konkret sammenheng. Funksjonshemming og kronisk sykdom er derfor et aspekt ved funksjonsevnevariasjoner, men begrepene tilhører ulike faglige tradisjoner (Thomas, 2007). Man trenger ikke å være syk for å ha en funksjonsnedsettelse eller for å bruke et hjelpemiddel, som for eksempel rullestol, og man er heller ikke nødvendigvis syk dersom man har en kronisk sykdomsdiagnose, som for eksempel multippel sklerose. Et «sykdomsblikk» på funksjonshemming er et perspektiv som retter søkelyset mer mot den personlige og individuelle situasjonen enn på samfunnsperspektivet.

Sentralt for det tverrfaglige feltet «disability studies», altså funksjonshemmingsforskning, er det man kan kalle en «vending mot omgivelsene». Et funksjonshemmingsperspektiv retter søkelyset mot sosiale og relasjonelle aspekter og har oppmerksomheten på samfunnsnivået, altså på det politiske og på diskriminering. Dette innebærer en kritikk av sykdomsblikket - eller den medisinske modellen - der man tenker på funksjonshemming som et «problem» som ligger hos den enkelte, og der søkelyset er på diagnose og behandling (Shakespeare, 2014, s. 15).

Tverrfaglig funksjonshemmingsforskning vender blikket mot samfunnet og spør hvordan samfunnet kan legge til rette for et mangfold av kropper gjennom å fjerne sosiale, kulturelle og fysiske barrierer og ved å gjøre offentlige rom tilgjengelige for alle. Hvordan kan vi bli kvitt ekskluderende og diskriminerende praksiser som hindrer personer med funksjonsnedsettelse i å ta utdanning, få jobb eller delta i samfunnslivet på andre måter? Vendingen mot omgivelsene kan vektlegge ulike aspekter. I britisk tradisjon oppsto det som kalles for den sosiale modellen (Shakespeare, 2014, s. 19-22). I denne modellen forstås funksjonshemming som noe samfunnet påfører enkeltpersoner gjennom utilgjengelige bygg og offentlige rom og gjennom segregerende praksiser, som spesialskoler og institusjoner. Søkelyset har i forskningen vært rettet mot de sosiale, økonomiske, politiske, kulturelle og psykologiske grunnene for utestengingen av funksjonshemmede - og mot systemisk endring.

Personer med funksjonsnedsettelse kan også forstås som en minoritet som blir diskriminert, og som har rettigheter som må beskyttes. Det er særlig innen en amerikansk kontekst en slik minoritetsmodell har utviklet seg. Her har en knyttet an til den afroamerikanske borgerrettsbevegelsen 
fra 6o-tallet og pekt på likhetstrekk mellom marginalisering på grunn av etnisitet og funksjonsevne. Forskere innen denne retningen har utviklet begrepet «ableism», som vi i mangel på et norsk uttrykk kaller for «ableisme» i denne boken. Med ableisme/ableistisk menes fordommer mot mennesker med kropper som anses å avvike fra normalen, noe som resulterer i diskriminering (Goodley, 2011, s. 12).

Vendingen mot omgivelsene kan også handle om å utforske kulturen og se på hvordan ulike kulturer og samfunn konstruerer «det normale», og om hvordan funksjonshemming inkorporeres i eller ekskluderes fra forståelser av kroppslig normalitet og normativitet. Innenfor den kulturelle modellen har man utforsket litteratur, film og andre kulturelle uttrykk i ulike historiske epoker (Mitchell \& Snyder, 2001; Thomson, 1997). Forskere innen denne retningen drar veksler på feministisk teori, skeiv teori og kritisk kulturteori, og de viser hvordan synet på funksjonshemming gjennomsyrer alle aspekter ved kulturen, blant annet gjennom metaforbruk og resirkulering av klisjeer om annerledes kropper (Thomson, 1996).

I nordisk kontekst har forskere vært særlig opptatt av det relasjonelle aspektet, der samspillet mellom det enkelte individet og samfunnet står sentralt. En relasjonell modell forstår funksjonshemming som noe situasjonsbestemt, heller enn som tilhørende en persons essens (Tøssebro, 2004; Lid, 2020). I den norske velferdsstaten bidrar relasjonelle forståelser til å tydeliggjøre hvordan funksjonshemming, forstått som deltakelsesbegrensning, kan motvirkes.

Variasjoner i funksjonsevne tilhører menneskelivets grunnvilkår og menneskelig mangfold. Funksjonsnedsettelse som gir funksjonshemming er vanskelig å måle, fordi dette er kontekstuelt og avhenger av både personens omgivelser, tilgang til ressurser og individuelle forhold. Basert på landenes rapportering regner en med at omtrent 15 prosent av verdens befolkning lever med en form for funksjonsnedsettelse (World Health Organization [WHO], 2011, s. 29). Dette betyr at de fleste familier er berørt av temaet, enten direkte eller indirekte. Med tanke på religiøst medborgerskap betyr denne statistikken også at alle menigheter har ansatte og medlemmer i alle aldre som har variasjoner i funksjonsevne. Dermed er dette et allment og ikke et marginalt tema som handler om både enkeltpersoner og religiøse, kulturelle og sosiale fellesskap. 


\section{Variasjoner i funksjonsevne som utgangspunkt for teologisk refleksjon}

Funksjonshemming og variasjoner i funksjonsevne tilhører altså menneskelivets erfaringsmangfold. Dermed er det også av teologisk interesse. Funksjonshemmingsteologi har etter hvert blitt etablert som et fagfelt der en er opptatt av å forsøke å forstå kristen tro og praksis på bakgrunn av historiske og samtidige erfaringer til personer med funksjonsnedsettelse (Swinton, 2016, s. 172). Likevel har dette temaet ofte vært resultat av enkeltforskeres personlige engasjement eller interesse, og det har i liten grad vært gjort til gjenstand for bred teologisk refleksjon og samtale. De senere års teologisk fagkritiske arbeid knyttet til temaene kjønn, seksuell orientering, klasse og kultur har i skandinavisk kontekst i liten grad inkludert funksjonshemming. Samtidig møter vi eksplisitte og implisitte forestillinger om funksjonsevne og funksjonshemming, både i bibelske tekster og i kirkens tradisjon og praksis.

Funksjonshemming og funksjonsnedsettelse er et tema som kommer til uttrykk i ulike tekster i Bibelen. Fordi det i mindre grad har vært arbeidet tekstfortolkende og tradisjonskritisk med disse tekstene og de teologiske tradisjonene, har forestillinger til en viss grad blitt videreført i dagens kontekst, for eksempel i form av ureflekterte ideer om religiøs helbredelse og verdsetting av noen kropper mer enn andre, i forståelser av normativitet og annerledeshet samt i utformingen av kirkerom og i planer og strategier. Disse forestillingene trenger å gjennomtenkes teologisk med utgangspunkt i de nye menneskerettslige og samfunnsmessige perspektivene på funksjonshemming, som vi har skissert over.

Kirkenes Verdensråd (KV) har vært en pådriver for å styrke kirken som et inkluderende fellesskap. Fra det fjerde møtet i KV i 1968 - og i tiden etter - har alle generalforsamlinger i KV hatt hensynet til personer med funksjonsnedsettelse på agendaen. I 1998 ble Ecumenical Disability Advocates Network (EDAN) etablert på generalforsamlingen i Harare, med norske Toril Edøy som et av medlemmene. Den teologiske gjennomtenkingen av temaet ble formulert samlet i dokumentet A Church of All and for All i 2003 (KV, 2003). Deretter ble The Gift of Being vedtatt på generalforsamlingen til KV i Trondheim i 2016 (KV, 2016). Begge disse 
dokumentene er skrevet av EDAN og kan leses som teologiske og ekklesiologiske (det som handler om kirkens lære og praksis) fortolkninger av variasjoner i funksjonsevne som menneskelig vilkår.

A Church of All and for All ble vedtatt mindre enn ti år etter FNs standardregler. I 2016 ble så dokumentet The Gift of Being vedtatt, mindre enn ti år etter at FN-konvensjonen trådte i kraft. Gjennom disse to dokumentene følger Kirkenes Verdensråd opp FNs arbeid med funksjonshemming som menneskerettslig tema.

A Church of All and for All er uttrykk for en økumenisk (det vil si felleskirkelig) utforsking av temaet funksjonshemming i et menneskerettsperspektiv. Teksten tar et oppgjør med kirkelige barrierer og ekskluderende teologi og kaller kirken til å være et inkluderende fellesskap. Funksjonshemming forstås som alle menneskers grunnvilkår, heller enn som straff, tap eller mangel $(\mathrm{KV}, 2003, \$ 1-21)$. Flere av denne bokens kapitler trekker inn og diskuterer The Gift of Being, eller Tilvorelsens gave som den heter på norsk. Dokumentet, som er oversatt og utgitt på norsk av Norges Kristne Råd, består av fem deler og omhandler temaene «verdsetting av menneskelig mangfold», «skapelse som uttrykk for kjærlighet», «livet som gave», «sårbarhet, grenser og helbredelse» og «kallet til å være en kirke for alle og med alle» (Norges Kristne Råd [NKR], 2017). Også dette dokumentet er, i likhet med CRPD, preget av en verdsetting av variasjoner i funksjonsevne som en del av menneskelig mangfold - og dermed av en viss skepsis til religiøs helbredelse. Teksten løfter frem alle menneskers gudbilledlikhet og bruker Paulus sitt bilde av menigheten som Kristi kropp for å fremheve alle medlemmenes betydning. På spørsmålet om helbredelse tar teksten et oppgjør med ableistiske antakelser om at alle som har en funksjonsnedsettelse, ønsker å bli helbredet:

Når vi vitner om mennesker med funksjonsnedsettelser som gaver til Kristi kropp, hvorfor er da helbredelse et tema? Hvordan skal vi forholde oss til det faktum at mange av disse menneskene selv sier at de hverken vil eller trenger å helbredes fra sin funksjonsnedsettelse? (NKR, 2017, §107)

De internasjonale dokumentene CRPD og Tilvarelsens gave er uttrykk for at funksjonshemming er et komplekst tema som det er viktig å ha 
kunnskap om, innen både teologi, pedagogikk og helse- og velferdsfag. I norsk sammenheng har den lutherske kirken vektlagt troens kognitive sider. Historisk har dette ført til at den som ikke kunne lære seg troens læreinnhold (katekismen) og dermed gjøre rede for innholdet i den kristne tro, ikke kunne bli konfirmert. Frem til 1912 var konfirmasjon obligatorisk i Norge, og den som ikke var konfirmert, kunne ikke gå til nattverd og heller ikke gifte seg eller få arbeid. Både døve og utviklingshemmede var blant dem som ble utestengt fra konfirmasjonen av denne grunn. Bruk av tegnspråk og prester som kunne kommunisere med døve på tegnspråk, ble utover i det 20. århundre avgjørende for at døve kunne få trosopplæring og bli konfirmert (Lid, 2018). Personer med kognitiv funksjonsnedsettelse har opplevd ekskludering fra religiøse fellesskap helt opp til vår tid.

Nettopp på denne bakgrunnen er dokumentene fra Kirkenes Verdensråd så viktige. Det første, A Church of All and for All fra 2003, ble aldri oversatt til norsk, og det er ikke brukt i særlig omfang ved de teologiske utdanningene (Lid, 2017). Det nyeste dokumentet, Tilvorelsens gave (NKR, 2017) bør derfor gjøres bedre kjent, slik at det kan bli brukt både i utdanningene, i forskning og i kirkelig praksis.

\section{Funksjonshemmingsteologi}

Som nevnt over har noen teologer trukket veksler på den tverrfaglige funksjonshemmingsforskningen og teoriutviklingen innen feltet for å utvikle en funksjonshemmingsteologi. Arbeidet innen funksjonshemmingsteologi trekker på innsikter fra andre disipliner, som for eksempel samfunnsfag, kjønnsforskning og filosofi. USA var tidlig ute, og Nancy Eieslands bok The Disabled God fra 1994 regnes som banebrytende. Denne boken står i en frigjøringsteologisk tradisjon og bidrar til nytenkning, både teoretisk og praktisk. Eiesland kritiserer den langvarige kristne tradisjonen som knytter funksjonshemming til synd ved blant annet å bruke evangelienes helbredelsesfortellinger som bilder på moralsk imperfeksjon eller guddommelig straff. Hun er opptatt av at funksjonshemmedes erfaringer må rommes i teologien. Dette viser hun blant annet ved å peke på Kristi kropp som en kropp som rommer erfaringen av funksjonsnedsettelse. 
Hvem er det vi minnes i nattverden, spør hun. Det er den korsfestede og oppstandne Kristus, som hun kaller den «funksjonshemmede Gud» («the disabled God»). Om oppstandelsen sier hun at den slett ikke er en utvisking av levd liv eller perfeksjonering av kropper. Kristi oppstandelse gir håp om at også ukonvensjonelle kropper deltar fullt i imago Dei, gudbilledlikheten, og at Gud har latt seg berøre av erfaringen med å være en funksjonshemmet kropp (Eiesland, 1994, s. 107).

Deborah Creamer har en litt annen innfallsvinkel. Hun forsøker å ta et oppgjør med en «dem og oss»-tenkning som skiller skarpt mellom «ikke-funksjonshemmede» og «funksjonshemmede» (Creamer, 2009). Denne dikotomien har ifølge Creamer ikke rot i virkeligheten, den er altså empirisk feil. Kategoriene er mer flytende. For eksempel får mange en kronisk sykdom eller funksjonsnedsettelse i løpet av livet. Noen mennesker har dager der form og funksjonsevne er bedre enn andre dager. Dessuten handler det også om grader av funksjonsnedsettelse, for eksempel fra det å trenge briller for å kunne lese til å være blind. Creamers poeng er at det å være kroppslig er en begrensning i seg selv, og at dette er et utgangspunkt alle mennesker har. Hun har derfor utviklet en modell for å forstå funksjonshemming som hun kaller «begrensningsmodellen» («the limits model»). Om denne modellen som teoretisk innramming sier hun:

[Modellen] understreker det faktum at vi alle erfarer begrensninger, at disse begrensningene varierer, og at disse begrensningene blir akseptert, avvist, fremhevet, vanskeliggjort, fornedret og levd på mange forskjellige måter. [Begrensningsmodellen] gir oss muligheten til å tenke på begrensning som en naturlig og god del av det å være menneske, som samtidig er grunnleggende vanskelig og utfordrende. (Creamer, 2009, s. 33, vår oversettelse)

Creamers modell kan bryte opp det fiktive skillet mellom et «oss» og et «dem». Vi er alle begrenset av den kroppen vi er gitt, og som livet kontinuerlig gir oss, og ingen kan projisere «begrensning» til å være noe bare «de funksjonshemmede» har. Gjennom livsløpet erfarer vi alle også endringer i kroppens begrensninger og muligheter.

Det å tenke fellesskap fra et mangfoldsperspektiv er etter hvert blitt utforsket av flere innenfor religionsfaget og teologien. Dette gjelder ikke 
minst for fellesskap med personer med kognitiv funksjonsnedsettelse (Young, 2007, 2011; Reynolds, 2008; Reinders, 2008; Hauerwas, 2005; Swinton, 2016; Dahle \& Torgauten, 2015). Bioetiske utfordringer knyttet til diagnostisering av potensiell funksjonsnedsettelse på fosterstadiet, såkalt prenatal diagnostisering, er også et tema som er belyst og diskutert teologisk (Swinton \& Brock, 2007; Lid, 2012b). Både menneskesyn og forståelser av helse og det gode liv samt den teologiske innrammingen av funksjonsnedsettelse er viktig. En entydig negativ forståelse av funksjonsnedsettelse, hvor for eksempel dette menneskelige vilkåret forstås som en konsekvens av synd, kan gjøre personer med funksjonsnedsettelse mer sårbare i religiøse fellesskap. Derfor er det viktig å synliggjøre at funksjonsevnevariasjoner ikke er til hinder for å leve et liv med god livskvalitet og mulighet for livsutfoldelse (Reinders, 2010; Bickenbach, Felder \& Schmitz, 2013; Nussbaum, 2007).

Samtidig er det slik at funksjonsnedsettelse og sykdom kan gjøre den enkelte ekstra sårbar og utsatt. Covid-19, som spredde seg som en global pandemi i 2019 og 2020, synliggjør denne sårbarheten. Personer med funksjonsnedsettelse trenger kanskje helse- og omsorgstjenester for å kunne leve et godt liv, og kan ha smerter og medisinske tilstander som krever behandling også under en pandemi. Det er derfor en oppgave for en ansvarlig velferdsstat både å forsøke å begrense negative konsekvenser av funksjonsnedsettelse og samtidig legge til rette for at det er mulig å leve et godt og meningsfullt liv med funksjonsnedsettelse og kronisk sykdom. Et funksjonshemmingsperspektiv betyr derfor ikke at en ikke er klar over at et liv med funksjonsnedsettelse kan være vanskelig og annerledes, også når det gjelder smerter og behov for omsorg.

For religiøs praksis og teologisk teori kan variasjoner i funksjonsevne og helse være en utfordring innen sjelesorg, med tanke på eksistensielle spørsmål knyttet til livets mening og i forhold til gudsforståelse. I sjelesørgeriske samtaler skal det være rom for det som er vanskelig, og som kjennes ekstra sårbart og smertefullt. Samtidig skal sjelesørgere unngå å representere stigmatiserende holdninger til hva et liv med funksjonsnedsettelse innebærer. Det kalles noen ganger et paradoks at funksjonsnedsettelse ikke er til hinder for å kunne leve et godt liv (Bickenbach et al., 
2013; Hanisch, 2013). I en velferdsstat som den norske bør ikke dette være et paradoks, fordi vi må kunne forvente at tilretteleggingen er god nok til at alle kan leve gode liv. Derfor er det også viktig at sjelesørgere unngår å entydiggjøre de vanskelige aspektene ved dette livsvilkåret. De tidligere nevnte omforente dokumentene fra Kirkenes Verdensråd er, sammen med CRPD, kilder til å forstå og motvirke forhold i samfunnet som gjør livet med funksjonsnedsettelse entydig negativt og vanskelig.

\section{Den nordiske teologiske konteksten}

Nordisk teologi har, med få unntak, ikke viet mye oppmerksomhet til temaet variasjoner i funksjonsevne og funksjonshemming. Det som kjennetegner en norsk kontekst innen systematisk teologi, er vekten på skapelsesteologi med viktige bidrag fra Knud E. Løgstrup og Gustav Wingren (Wingren, 2004; Løgstrup, 1995). Skapelsesteologien er en fruktbar innramming for forståelse av funksjonsevnevariasjoner fordi den gir mulighet for å se skapelsen som en mangfoldig helhet og mennesket som en del av denne helheten (Lid, 2012b; NKR, 2017).

Den teologiske refleksjonen har i særlig grad en kritisk brodd mot et kapitalistisk menneskesyn som forstår mennesket som aktivt produserende, ytende og forbrukende gjennom hele livet. Mot dette fremholdes et menneskesyn som ser mennesket primært som mottakende og deltakende i mottakende fellesskap. Teologisk er gudbilledlikheten en kilde til å forstå mennesket som skapt, mottakende og i relasjon til Gud. Livet er gitt, i et mangfold, og dette mangfoldet er både en gave og en oppgave for det borgerlige samfunnet (Lid, 2017). I dette ser vi også et grunnlag for kritikk av begrepet «funksjonshemmet» og «funksjonsnedsettelse», fordi det ikke er menneskets evner til å fungere og prestere som definerer mennesket, men de relasjonelle dimensjoner i mennesket som gjør at mennesket alltid, direkte eller indirekte, står i relasjon til andre.

Funksjonshemmingsteologi handler også om menneskesyn. For eksempel er spørsmålet om hvem som skal kunne være prest og inneha lederposisjoner i kirken, relevant. Slik sett er det her også likhetstrekk med temaene kjønn og seksuell orientering. Forestillingen om at prestene skal være «lytefrie», med røtter i Det gamle testamentets renhetsforskrifter, 
kan forstås både moralsk og kroppslig, og har fått konsekvenser for hvem som anses som egnet til å virke som prest og religiøs leder.

At Gud også er en sårbar Gud, er i denne sammenhengen mindre artikulert, men desto viktigere å løfte frem. Sårbarhet og variasjoner i funksjonsevne som grunnleggende vilkår for menneskelivet har imidlertid teologiske konsekvenser også når det gjelder gudsbilde, noe Eiesland poengterte nettopp gjennom tittelen på sin bok The Disabled God (Eiesland, 1994). Dette pedagogiske og teologiske poenget er blitt verdsatt og brukt av mange for å understreke at en funksjonshemmet Gud er alles Gud (Young, 2016). Et gudsbilde som inkluderer funksjonshemming, oppleves slik som et inkluderende gudsbilde. Gud deler menneskers vilkår (Lid, 2012b, s. 16).

Variasjoner i funksjonsevne, funksjonsnedsettelse og kronisk sykdom forbindes ofte, både teologisk og allment, med lidelse og vansker. Dette er ikke urimelig, siden det for mange er lidelse knyttet til å leve med enten funksjonsnedsettelse eller kronisk sykdom. På denne bakgrunnen har det vært relativt sterke teologiske tradisjoner som har forstått sykdom og funksjonsnedsettelse som konsekvens av syndefallet og derfor ikke i samsvar med Guds plan eller vilje. Dette er et utfordrende tema, fordi det på den ene siden kan oppleves problematisk å hevde at det er Guds vilje at en person skal ha denne type livsvilkår. På den andre siden er det også teologisk problematisk å si til en person at vedkommendes liv ikke er i samsvar med Guds vilje, men en konsekvens av syndefallet. Mange funksjonshemmingsteologer har tatt et oppgjør med denne typen teologiske tradisjoner. En måte å forsøke å komme til rette med dette på er å unngå å sette likhetstegn mellom funksjonsnedsettelse og lidelse. Det er ikke i strid med muligheter for et godt liv å ha funksjonsnedsettelse og kronisk sykdom (Bickenbach et al., 2013; Hanisch, 2013). Vi vet også at forhold i omgivelsene, som diskriminering og mangel på muligheter til å ta utdanning, få jobb, finne bolig og så videre, ofte er medvirkende til at dette livsvilkåret oppleves vanskelig.

Et annet viktig perspektiv handler om å utforske mangfold i skaperverket og blant mennesker som en kilde til innsikt om både Gud og det skapte. Skaperverket er preget av mangfold på alle måter og for alle arter. Ikke to snøfnugg er like, heller ikke to mennesker. Variasjon og 
mangfold er derfor en innebygd kvalitet i det skapte. Dette er et godt teologisk grunnlag for å si noe om likeverd og likestilling, og dermed også om religiøst medborgerskap. Skaperverkets gudgitte mangfold gir en teologisk begrunnet verdsetting av variasjoner i funksjonsevne som noe som tilhører menneskelig mangfold. Innenfor tverrfaglig funksjonshemmingsforskning kalles dette for en anerkjennende fortolkning av funksjonsevnevariasjoner («affirmativ model of disability») (Swain \& French, 200o; Solvang, 2019). En slik fortolkning innebærer en verdsetting av ulike former for annerledeshet som preger menneskelivet. I stedet for å betrakte visse former for menneskelig mangfold som feil som skal korrigeres, kan vi si at intet menneskelig er teologien fremmed, og at nettopp mangfoldet skal verdsettes. Dette er en fortolkning som knytter an til en skandinavisk skapelses- og sårbarhetsteologi.

\section{Perspektiver fra diakoni}

Finnes det et diakonalt perspektiv på funksjonsnedsettelse og funksjonshemming? I den norske kirke er diakoni tradisjonelt forstått som kirkens omsorgstjeneste (Kirkerådet, u.å.). I en slik begrepsforståelse ligger det implisitt en antakelse om at noen gjør en omsorgstjeneste for noen andre. Dermed har diakonien bidratt til å fastholde et skille mellom dem som trenger hjelp, og dem som gir hjelp (Lid, 2018). Men denne tradisjonelle måten å tenke diakoni på er blitt utfordret av internasjonale strømninger innen det diakonale fagfeltet som er orientert mot menneskerettigheter og rettferdighet. Vi ser muligheter for at nye teologiske og politiske dokumenter som Tilvorelsens gave og CRPD kan være rike kilder til å utvikle en funksjonshemmingsdiakoni som preges av likeverd og medborgerskap. Diakoni i denne nye forståelsen handler om å ha og gi rom for sårbarhet. Funksjonshemmingsperspektivet kan hjelpe oss å forstå at sårbarheten er universell og noe vi alle er berørt av, om enn på ulike måter. En diakoni som gir rom for sårbarhet i fellesskap, kan bidra til å fjerne dikotomier mellom dem som gir og dem som får, og til å tydeliggjøre at alle fellesskap er preget av mottakelse og sjenerøsitet, men også av begrensninger. Noen av bokens kapitler er diakonifaglige bidrag som 
utforsker variasjoner i funksjonsevne og funksjonshemming i diakonale kontekster.

\section{Etikk og profesjonell praksis}

Forståelser av funksjonshemming er også etisk relevant. Dersom funksjonsnedsettelse forstås som entydig negativt, blir det vanskelig for en person med funksjonsnedsettelse å finne en plass som likeverdig deltaker og medarbeider i et religiøst fellesskap. Det har i lengre tid vært oppmerksomhet på hva slags kunnskap menigheter og religiøse fellesskap må ha for å kunne tilrettelegge godt for mangfold innen kjønn og seksuell orientering. I denne antologien ønsker vi å bidra til å øke kunnskapen om mangfold i funksjonsevne. Slik kunnskap er viktig for å kunne legge til rette for både deltakelse, medvirkning og dermed religiøst medborgerskap.

For noen personer vil likeverdig mulighet for religiøs deltakelse avhenge av individuell tilrettelegging og tjenester. Derfor er det også profesjonsetisk relevant for helse- og velferdsprofesjonene å ha kunnskap om religiøst medborgerskap. Profesjonsetikken omfatter også prester, diakoner, kateketer, kirkemusikere og trosopplærere, som alle er viktige for at religiøs deltakelse skal være mulig for alle som ønsker det. Profesjonell praksis bygger på menneskerettighetene og skal fremme likeverd og likestilling. CRPD er den nyeste av menneskerettighetskonvensjonene og derfor også den som er minst kjent. Samtidig er ikke rettighetene til religiøs deltakelse for personer med funksjonsnedsettelse godt nok ivaretatt i dag. Dette er en utfordring til både teologi og diakoni som er nødvendig å ta på alvor.

\section{Bokens kapitler}

Kapitlene i denne boken er delt i tre deler. Første del tar for seg ulike aspekter ved religiøst medborgerskap i en norsk kontekst. I bokens første kapittel drøfter Dmitry Lukash hvordan det legges til rette for religiøst medborgerskap for mennesker med utviklingshemming i normative dokumenter fra den norske stat og Den norske kirke. Han påpeker at selv om lovgivningen og også profesjonsutdanningene er blitt stadig mer rettighetsbasert, er retten til religionsutøvelse ofte glemt eller underordnet 
«fritidssysler.» Her har Den norske kirke en viktig rolle som korrektiv, fordi den omtaler mennesker med utviklingshemming som handlende subjekter også på det religiøse plan.

Kapittelet som følger, skrevet av Inger Marie Lid, presenterer en studie av inkludering og tilrettelegging i Den norske kirkes konfirmasjonsundervisning. Dette er den delen av Den norske kirke sin trosopplæring som flest barn og unge deltar i, og studien undersøker i hvilken grad trosopplæringen er tilrettelagt slik at barn og unge med nedsatt funksjonsevne har likeverdig mulighet for deltakelse. Studien diskuteres i lys av teoretiske perspektiver på sårbarhet, mangfold og medborgerskap.

Det økumeniske dokumentet Tilvorelsens gave er utgangspunkt for Anita Gjermestads profesjonsetiske drøfting av hvordan profesjonelle omsorgsutøvere møter barn, unge og voksne med alvorlig utviklingshemming. Hun presenterer to tenåringsjenter, Nora og Maria, og drøfter deres aktørskap og medborgerskap. I kapittelet viser hun hvordan dokumentet fra Kirkenes Verdensråd kan bidra til å utvikle et profesjonsetisk språk som synliggjør menneskeverdet og aktørskapet til denne gruppen. Hun fremholder at de sentrale verdiene i Tilvorelsens gave åpner for nye forståelser av menneskesyn og medborgerskap for mennesker med alvorlig utviklingshemming.

Det siste kapittelet i denne delen er en casestudie av Tomaskirken i Andebu, som er en «sansekirke» spesielt tilrettelagt for døve, hørselshemmede og døvblinde. Leonora Onarheim Bergsjø analyserer kirkens estetikk og peker på betydningen det taktile har i denne kirken. Hun bruker perspektiver fra funksjonshemmingskunst («disability art») for å belyse den taktile estetikken i Tomaskirken.

I del to drøfter kapitlene ulike aspekter ved sårbarhet som menneskelig grunnvilkår. Kari Jordheims kapittel gir et diakonifaglig perspektiv på sårbarhet og religiøst medborgerskap. Hun analyserer dokumentene Tilvorelsens gave og Liv $i$ mangfoldig fellesskap fra Det lutherske verdensforbund, og hun drøfter hvordan kirken kan etablere felleskap hvor bidragene fra mennesker som lever med funksjonsnedsettelse, settes pris på og inkluderes. Det å leve sammen i slike mangfoldige fellesskap forutsetter at man er nødt til å krysse grenser og lære seg å overkomme redsel og usikkerhet i møte med forskjeller og annerledeshet. 
Hans Morten Haugen går i sitt kapittel gjennom de endringene som har skjedd i Den norske kirke de seneste årene når det gjelder forståelsen av menneskelig mangfold og inkludering. Han tar utgangspunkt i menneskerettighetene og presenter først en oversikt over viktige FNdokumenter som har hatt innflytelse på norsk lovgivning og politikk, deriblant CRPD. Han drøfter så hvorvidt denne menneskerettstenkningen har kommet til utrykk i sentrale dokumenter fra Den norske kirke siden 1990-tallet. Resultatet av undersøkelsen er tvetydig. Mens det er tydelig at religiøst medborgerskap vektlegges mer nå enn før, blant annet gjennom oppmerksomhet på inkludering og mangfold, er spørsmålet om dette ennå er blitt synlig i lokale praksiser.

Utviklingen innenfor bioteknologi de senere årene reiser nye etiske problemstillinger. For eksempel kan man nå få detaljert informasjon om fosteret tidlig i svangerskapet gjennom ikke-invasive tester (NIPT). Gunnar Heiene drøfter i sitt kapittel hvordan denne utviklingen utfordrer kristen etikk. Han peker på at feministisk etikk kan gi et viktig bidrag til nytenkning. Feministisk etisk teori bryter nemlig med en tradisjonell oppfatning av det fullstendig autonome subjektet og vektlegger «connectivity», altså det at mennesker er forbundet med hverandre.

Det neste kapitlet drøfter hvordan en samtidsroman kan bidra til refleksjon rund temaer som sårbarhet, funksjonsvariasjoner og likeverd. Nora Simonhjell løfter frem de sårbare situasjonene som karakterene i Olaug Nilsens kritikerroste roman Tung tids tale befinner seg i. En sliten mor forteller om sin kamp for sin autistiske sønn, og begge to er på ulikt vis sårbare. Slik kan en roman vise at sårbarhet er fundamentalt menneskelig, ikke noe som kan knyttes til enkeltmennesker eller grupper. Simonhjell beskriver boken som et laboratorium som gjennom estetiske virkemidler forstørrer og tydeliggjør menneskelige erfaringer og dermed ansporer til etisk refleksjon.

I Terese Bue Kessels kapittel som er det siste bidraget i denne delen, blir vi kjent med den sårbare situasjonen til infertile kvinner i Kamerun. Globalt opplever mange kvinner negative holdninger fra samfunnet dersom de ikke kan få barn, og infertilitet kan dermed forstås som en sosial eller kulturell funksjonsnedsettelse. Kessels studie av kvinner som er engasjert i den kristne kvinnebevegelsen «Kvinner for Kristus» viser at 
dette diakonale fellesskapet fungerer som en motsats til de patriarkalske ekskluderingspraksisene de ellers møter, både i kirken og i samfunnet generelt. Dette kvinnefellesskapet bidrar til religiøst medborgerskap for kvinner som er svært sårbare, ikke bare på grunn av infertilitet, men også på grunn av andre faktorer som kjønn, fattigdom og lav utdanning.

Den tredje delen av boken er viet teologiske refleksjoner. Som nevnt tidligere i denne innledningen har bibelfortellinger om helbredelse preget den vestlige kulturs forståelser av funksjonshemming, blant annet ved å knytte sammen sykdom og synd på den ene siden og helse og frelse på den andre. Anna Rebecca Solevåg viser i sitt kapittel at Det nye testamentet gir et mer mangfoldig bilde enn den tradisjonelle teologien skulle tilsi. Hun viser også hvordan perspektiver fra tverrfaglige funksjonshemmingsstudier kan brukes som en ressurs for bibeltolkning.

Knut Alfsvågs kapittel drøfter en teologisk retning som har vært spesielt orientert mot helbredelse fra sykdom, nemlig den helbredelsesforkynnelse som blant annet fins innen den pinsekarismatiske vekkelsen. Alfsvåg viser hvordan denne forkynnelsespraksisen vokste frem fra andre halvdel av 180o-tallet, og han vurderer den i lys av funksjonshemmingsteologi. Han påpeker at menneskesynet innenfor denne tradisjonen har ableistiske trekk - det er det kompetente, sterke og friske mennesket som er ideal.

Hva vil det si å være kirke? Og hvilke livserfaringer skal danne grunnlag for vår forståelse av hva kirken er? Dette er utgangspunktet for Gyrid Gunnes sitt kapittel, som drøfter nettopp ekklesiologi, læren om kirken. Hun bruker skuespiller Marte Wexelsen Goksøyr sin scenekunst til å utforske hvordan et funksjonshemmingsperspektiv kan bidra til å integrere andre livserfaringer i kirkeforståelsen. Gunnes sitt kapittel er et konstruktivt teologisk bidrag til tenkningen rundt religiøst medborgerskap. Som hun påpeker, handler det ikke bare om å integrere mennesker med nedsatte funksjonsevner i kirken. Vi må også tenke nytt om hvilke livserfaringer og praksiser som regnes som relevante for det «kirkelige».

Bokens siste bidrag tar opp igjen en tematikk som har gått som en rød tråd gjennom mange av kapitlene nemlig den tradisjonelle vestlige vekten på autonomi og rasjonalitet når menneskeverd og normalitet 
skal vurderes. Therese Marie Ignacio Bjørnaas viser hvordan tenkerne Augustin, Tomas Aquinas og Immanuel Kant har formet den moderne forståelsen av mennesket. Gjennom en nylesning av Thomas Aquinas argumenterer hun for at hans kroppsliggjorte teologi og forståelse av gudbilledlikheten (imago Dei) kan danne grunnlag for et menneskesyn som utfordrer den rasjonalistiske tradisjonen og heller retter søkelyset mot det relasjonelle aspektet ved menneskets gudsrelasjon.

\section{Referanser}

Barne-, likestillings- og inkluderingsdepartementet. (2013). Konvensjon om rettighetene til mennesker med nedsatt funksjonsevne (CRPD).

Bickenbach, J. (2012). Ethics, law, and policy. Los Angeles: SAGE.

Bickenbach, J., Felder, F. \& Schmitz, B. (2013). Disability and the good human life. New York: Cambridge University Press.

Creamer, D. B. (2009). Disability and Christian theology. Embodied limits and constructive possibilities. Oxford: Oxford University Press.

Dahle, S. \& Torgauten, T. I. (2015). Helt med! I samme fellesskap uavhengig av funksjonsevne. Oslo: Gyldendal Akademisk.

Eiesland, N. L. (1994). The disabled God. Toward a liberatory theology of disability. Nashville, TN: Abingdon Press.

Eiesland, N. L. \& Don, E. S. (Red.) (1998). Human disability and the service of God: Reassessing religious practice (s. 105-122). Nashville: Abingdon Press.

Hanisch, H. (2013). Recognizing disability. I J. Bickenbach, F. Felder \& B. Schmitz (Red.), Disability and the good human life. New York: Cambridge University Press.

Hauerwas, S. (2005). Chapter 1. Timeful friends. Journal of Religion, Disability and Health, 8(3), 11-25.

Isin, E. F. \& Nielsen, G. M. (2008). Acts of citizenship. London, England: ZED Books.

Justis- og beredskapsdepartementet (2014). Lov om styrking av menneskerettighetens stilling i norsk rett.

Kirkenes Verdensråd (KV). (2003). A church of all and for all: An interim statement. Geneva: World Council of Churches.

Kirkenes Verdensråd (KV). (2016). The gift of being: Called to be a church of all and for all. Bossey Ecumenical Institute.

Kirkerådet. (u.å.). Plan for diakoni. Hentet 25.02.20 fra https://kirken.no/ globalassets/kirken.no/om-kirken/slik-styres-kirken/planer-visjonsdokumentog-strategier/plan_diakoni_2010_bokmaal2.pdf 
Lid, I. M. (2012a). Disability as a human condition discussed in a theological perspective. Diaconia, 3, 158-171.

Lid, I. M. (2012b). Likeverdig tilgjengelighet? En drøfting av menneskesyn og funksjonshemming med vekt på etiske problemstillinger knyttet til universell utforming, mangfold og deltakelse (nr. 43). Oslo: Unipub.

Lid, I. M. (2014). Universal design and disability: An interdisciplinary perspective. Disability and Rehabilitation, 36(16), 1344-1349.

Lid, I. M. (2017). Challenges from the UN Convention on the Rights of Persons with Disabilities: Equal access to theology and church practice in the Church of Norway. Journal of Religion, Disability \& Health.

Lid, I. M. (2018). Diakoni og velferdsstat: Utvikling av en diakonal praksis i samspill med myndigheter, sivilsamfunn og borgere. Oslo: Gyldendal Akademisk.

Lid, I. M. (2020). Universell utforming og samfunnsdeltakelse. Oslo: Cappelen Damm Akademisk.

Løgstrup, K. E. (1995). Ophav og omgivelse: betragtninger over historie og natur. København: Gyldendal.

Mitchell, D. T. \& Snyder, S. L. (2001). Narrative prosthesis. Disability and the dependencies of discourse. Ann Arbor, MI: University of Michigan Press.

Norges Kristne Råd [NKR]. (2017). Tilvorelsens gave. Kalt til å vore kirke av alle og for alle. Norges Kristne Råds skriftserie, nr. 20. Oslo: Norges Kristne Råd.

Nussbaum, M. C. (2007). Frontiers of justice: Disability, nationality, species membership. Cambridge, MA: Belknap Press of Harvard University Press.

Reinders, H. S. (2008). Receiving the gift of friendship: Profound disability, theological anthropology and ethics. Grand Rapids, MI: Eerdmans.

Reynolds, T. E. (2008). Vulnerable communion. A theology of disability and hospitality. Grand Rapids: Brazos Press.

Shakespeare, T. (2014). Disability rights and wrongs revisited (2. utg.). London: Routledge.

Solevåg, A. R. (2018). Negotiating the disabled body: Representations of disability in early Christian texts. Atlanta, GA: SBL Press.

Solvang, P. K. (2019). (Re)habilitering: Terapi, tilrettelegging, verdsetting (1. utg. red.). Bergen: Fagbokforlaget.

Sosial- og helsedepartementet. (2001). FNs standardregler for like muligheter for mennesker med funksjonshemming.

Swain, J. \& French, S. (2000). Towards an affirmation model of disability. Disability \& Society, 15(4), 569-582. https://doi.org/10.1080/09687590050058189

Swinton, J. \& Brock, B. (2007). Theology, disability and the new genetics: Why science needs the church. London: T\&T Clark.

Swinton, J. (2016). From inclusion to belonging: Why 'disabled' bodies are necessary for the faithfulness of the church. I A. Picard \& M. Habets (Red.), Theology and 
the experience of disability. Interdisciplinary perspectives from voices down under (s. 171-181). New York: Routledge.

Thomas, C. (2007). Sociologies of disability and illness: Contested ideas in disability studies and medical sociology. Houndmills, England: Palgrave Macmillan.

Thomson, R. G. (1996). Freakery. Cultural spectacles of the extraordinary body. New York: New York University Press.

Thomson, R. G. (1997). Extraordinary bodies. Figuring physical disability in American culture and literature. New York: Columbia University Press.

Tøssebro, J. (2004). Introduction to the special issue of SJDR: Understanding disability. Scandinavian Journal of Disability Research, 6(1), 3-7.

Wingren, G. (2004). Menneske og kristen: en bog om Irenæus og Grundtvig. Herning: Poul Kristensens Forlag.

World Health Organisation (WHO). (2011). World report on disability. Genève: World Health Organization.

Yong, A. (2007). Theology and down syndrome. Reimagining disability in late modernity. Waco, TX: Baylor University Press.

Yong, A. (2011). The Bible, disability, and the Church: A new vision of the people of God. Grand Rapids, MI: William B. Eerdmans Publishing.

Young, A. (2016). Disability and the renewal of theological education: Beyond ableism. I A. Picard \& M. Habets (Red.), Theology and the experience of disability. Interdisciplinary perspectives from voices down under (s. 250-263). New York: Routledge. 



\title{
KAPITTEL 1
}

\section{Utviklingshemmedes rett til religionsutøvelse i Norge}

\author{
Dmitry Lukash \\ VID vitenskapelige høgskole
}

\begin{abstract}
This chapter attempts to give a brief overview of how the key legal acts and policies of the Norwegian state and the Church of Norway address religiosity and religious needs of people with intellectual disabilities. The main focus is on how those issues are connected to universal human rights and civil and political freedoms, as well as to national policy for combating all forms of discrimination, and on the extent to which people with intellectual disabilities are represented in such policy as religious subjects, and not merely objects of welfare. In discussing Norwegian public policy, I review international conventions such as the Convention on the Rights of Persons with Disabilities (CRPD), Norwegian laws and regulations such as the Human Rights Act (1999) and Norwegian Official Report NOU 2016: 17 "På lik linje", relevant regulations and curricula for professional education and training. I also show how main policy documents of the Church of Norway address these issues. In this chapter I attempt to show that in contrast to the rather modest attention paid to the religiosity of people with intellectual disabilities by the official policy texts, the Church of Norway's official policy appears to be one of significant engagement in advocacy for these people's religious rights.
\end{abstract}

Keywords: people with intellectual disabilities, religious subjects, human rights, Church of Norway, normative documents

\section{Innledning}

I dette kapitlet gir jeg en oversikt over i hvilken grad religiøsitet, religiøse behov og praksis hos mennesker med utviklingshemming blir behandlet 
i normative dokumenter fra den norske stat og Den norske kirke, og i hvilken grad disse kan fremme utviklingshemmedes aktive rolle som religiøse subjekter. Psykisk utviklingshemming er på den ene siden en diagnose i henhold til ICD-10 som betegner en betydelig svekkelse av evnenivå, sosial modenhet og evner til å klare seg i det daglige liv, og som ikke har oppstått i voksen alder (Ellingsen \& Sandvin, 2014, s. 22).

På den andre siden er det åpenbart at denne definisjonen rommer et mangfold av ikke bare funksjonsnivåer, men også av mennesker med høyst ulike psykiske, mentale, verbale og sosiale evner samt et mangfold av ulike kulturelle, etniske, religiøse og sosiale bakgrunner. Det som kjennetegner dem alle, er at de blir definert og kategorisert som utviklingshemmede av stats-, velferds- og omsorgsinstitusjoner. Utviklingshemming representerer derfor en institusjonell identitet, en identitet som er etablert og opprettholdt av varige handlingsmønstre, normer og tenkemåter rundt hva det er å være utviklingshemmet (Järvinen \& Mik-Meyer, 2003; Sandvin 2014, s. 98). Denne kategoriseringen av en gruppe mennesker som utviklingshemmede har tradisjonelt vært tett knyttet til definisjonen av dem som annerledes, «de andre», og den har vært forbundet med behovet for omsorg, enten omsorgen gis gjennom fysisk plassering på institusjoner, slik det var tilfellet i Norge før HVPU-reformen, eller på andre måter (Sandvin, 2016, s. 101; Gustavsson \& Nyberg, 2014, s. 120).

Det er riktignok ingenting spesielt med dette. Mekanismer for identitetsdannelse og kategorisering av mennesker med utviklingshemming bygger på generelle metoder for dannelse av sosiale identiteter, og de er ikke helt ulike for eksempel kategorisering av mennesker på grunnlag av etnisitet eller tilhørighet til minoritetsgrupper (Jenkins, 2008; Gustavsson \& Nyberg, 2016, s. 120). Disse mekanismene bidrar også til forståelsen av utviklingshemmede som religiøse subjekter, det vil si som mennesker som ikke bare har visse religiøse eller åndelige behov som «er der» for å tilfredsstilles av velferdstjenester, men som gjennom aktiv praksis definerer seg selv og sin identitet. ${ }^{1}$

1 Det er viktig å legge merke til at jeg ikke mener at alle mennesker nødvendigvis er religiøse. Man skal ikke tilskrive religiøsitet til dem som ikke ønsker å bli kategorisert som religiøse. Det er ikke uproblematisk å gå fra det ene ytterpunktet, der man kategoriserer mennesker med 
Dette kapitlet er skrevet i sammenheng med mitt pågående forskningsprosjekt om helse- og omsorgspersonell som arbeider ved omsorgsboliger og dagsentra for mennesker med utviklingshemming, og om deres holdninger til og oppfatninger om brukernes religiøsitet og religiøse praksis. Mens selve prosjektet er en empirisk studie, vil dette kapitlet bidra til å sette resultatene inn i en bredere institusjonell og normativ sammenheng.

\section{Kan mennesker med utviklingshemming være religiøse subjekter?}

Selv om det de siste tiårene har vært en betydelig teologisk refleksjon rundt utviklingshemming (se Swinton, 2011), har religion, religiøs praksis og behovene hos denne gruppen mennesker ikke vært gjenstand for særlig mye empirisk forskning (Swinton, 2002; Shogren \& Rye, 2005). Det har i enda mindre grad blitt forsket på dette området i et nordisk perspektiv.

Det finnes likevel forskning som tydelig viser at mennesker med kognitive funksjonsnedsettelser har åndelige og religiøse behov, og at disse er blant de mest sentrale for dem. I en studie av 41 amerikanere med mild til moderat utviklingshemming fant Shogren og Rye (2005) for eksempel at deres respondenter skåret høyt på integrert religiøsitet, det vil si religiøsitet som stammer fra egne holdninger og overbevisninger, og som setter preg på hele livet. De brukte også religion aktivt som en kilde til trøst og støtte. I en britisk studie av 29 mennesker med utviklingshemming fant Turner med flere (2004) at mange av dem definerte seg selv som religiøse og hadde en bevisst religiøs tilhørighet (Turner et al., 2004; Sango \& Forrester-Jones, 2017). I en annen britisk studie viste Swinton (2002) at mange av hans informanter hadde en dyp åndelighet og ofte søkte etter mening, trygghet og kjærlighet hos Gud eller andre høyere makter (Swinton, 2002; Sango \& Forrester-Jones, 2017).

Med andre ord bekrefter forskningen det som ofte blir glemt og skjøvet bort, nemlig at den religiøse, åndelige siden ved livet til utviklingshemmede ikke bare finnes, men bør vies oppmerksomhet. Selv om deres

utviklingshemming som fullstendig irreligiøse, til det motsatte ytterpunktet, der alle blir tilskrevet religiøs subjektivitet. 
menneskerettigheter blir stadig mer stadfestet internasjonalt, og deres egen stemme blir stadig mer hørt, bør vi også anerkjenne deres subjektivitet, selvbestemmelse og handlingsevne på det området som handler om livets store spørsmål.

\section{Norge: det sekulære og det religiøse}

For en bedre og mer kontekstuell forståelse av den rollen utviklingshemmedes religionsfrihet spiller i norske statlige og kirkelige styringsdokumenter, er det viktig å kaste et blikk på religionens stilling i dagens norske samfunn.

Man tenker gjerne på Norge som et ganske sekulært samfunn. I lys av variabler som kirkegang og tro på etablerte religiøse forestillinger kan man plassere Norge, sammen med de andre nordiske landene, blant de mest sekulariserte regionene i Europa (Davie, 2002; Zuckerman, 2009; Schmidt, 2010b). For eksempel var det færre som gikk til gudstjeneste i Den norske kirke i 2008 enn i 1991, samtidig som andelen av befolkningen som ikke regner seg som troende, har vokst i løpet av den samme perioden (Botvar, 2010). Samtidig er det viktig å påpeke at selve begrepet sekularisering er langt fra entydig og uproblematisk.

Det har lenge vært vanlig, også blant religionssosiologer, å tro at i takt med modernisering, rasjonalisering og livssynsdifferensiering blir religionen gradvis svekket og forvist til den private sfæren (se f.eks. Berger, 1967). Denne forståelsen har imidlertid kommet under kritikk, særlig siden slutten av 1990-tallet (Berger, 1999; Gorski \& Altinordu, 2008). Statistiske data som viser nedgang i organisert religiøsitet, gjelder først og fremst Europa, og de er langt fra entydige når det gjelder resten av verden. Forskere er heller ikke enige om innholdet i selve sekulariseringsbegrepet (Gorski \& Altinordu, 2008, s. 59; Davie, 1999).

Som en løsning kan man betrakte dette fenomenet, slik blant andre den belgiske sosiologen Karel Dobbelaere har gjort, som bestående av tre nivåer: det samfunnsmessige (religionen mister sin stilling som en overordnet ramme for samfunn og stat), det organisatoriske (religiøse institusjoner og organisasjoner sekulariseres i sin egen interne struktur og virksomhet) og det individuelle (menneskene blir mindre religiøse) 
(Dobbelaere, 1981, 2002). Sekulariseringsprosesser kan dermed arte seg ulikt på forskjellige nivåer. Slike tredimensjonale modeller er nyttige fordi de kan skille mellom prosesser på makro-, meso- og mikronivå, og vise at disse prosessene kan foregå på forskjellige måter (jf. Casanova, 1994). Her skal jeg rette oppmerksomheten mot religionens stilling på det overordnede politiske og samfunnsmessige nivået, noe som kan kaste lys over religionens rolle og plass i de overordnede politiske rammene og målsettingene som gjelder funksjonshemming.

På makronivå har Norge tradisjonelt vært dominert av én trosretning, nemlig den lutherske kristendommen, og ett trossamfunn, nemlig Den norske kirke (DNK), som til helt nylig har hatt offisiell status som statskirke (Schmidt, 2010). Selv om denne institusjonens stilling vis-a-vis staten har gjennomgått en forandring (basert på en politisk avtale inngått 10. april 2008 og implementert i en grunnlovsendring $i$ 2012) og per i dag er formelt atskilt fra den norske stat, beholder den fortsatt en privilegert stilling som folkekirke, og den spiller dermed fortsatt en sentral rolle i majoritetens religiøse tilhørighet (Kultur- og kirkedepartementet, 2008; Schmidt 2010a; Botvar, 2010). Mens Norges grunnlov i paragraf 2 tidligere slo fast at «Den evangelisk-lutherske Religion forbliver Statens offentlige Religion», angir den nye versjonen at «Den norske kirke, en evangelisk-luthersk kirke, forblir Norges folkekirke og understøttes som sådan av staten», mens «[n]ærmere bestemmelser om Kirkens ordning fastsettes ved Lov». (Grunnloven, 2018, $\$ 16$ ). Slik har det flertydige begrepet «folkekirke» blitt en del av den norske Grunnloven.

Det er hensiktsmessig å rette blikket mot dette begrepet. I dokumentet Den norske kirkes identitet og oppdrag, vedtatt av Kirkemøtet i 2004, heter det at Kirkens identitet skal forbli «en bekjennende, misjonerende, tjenende og åpen folkekirke» og være et felleskap av alle døpte medlemmer (Kirkemøtet, 2004, s. 4, 7). Samtidig presiseres det at Kirken er en åpen kirke som «skal gi rom for menneskelivets mangfold i hverdag og fest [samt] lytte til menneskers livserfaringer og spørsmål, og tilby fellesskap som gir forankring og tilhørighet» (Kirkemøtet 2004, s. 6). I denne sammenheng kan DNKs folkekirkelighet også tolkes som at den ikke stiller noen krav til sine medlemmer ut over dåpen, og at dens tjenester er «allment tilgjengelige og gratis» (Kultur- og kirkedepartementet, 2008, s. 32). 
Selv om kirkens atskillelse fra staten ble fulgt av en nedgang i medlemstallet (fra 81 prosent i 2009 til 75 prosent i 2014), er Den norske kirke fortsatt det største trossamfunnet i Norge. Som jeg videre skal vise, har den med sin institusjonelle vekt og fortsatte forankring blant flertallet av befolkningen stor betydning når det gjelder å være en stemme i den offentlige samtalen og politikken med tanke på religiøse behov og rett til religionsutøvelse blant mennesker med utviklingshemming.

Når det er sagt, må det ikke glemmes at Norge er og lenge har vært et religiøst og livssynsmessig mangfoldig samfunn som omfatter mennesker som tilhører alle verdens store religioner så vel som livssynshumanister (Schmidt, 2010b). Det ligger imidlertid utenfor dette kapitlets hensikt å undersøke disse religiøse- og livssynsorganisasjoner sitt offisielle ståsted eller vedtatte politikk. Som jeg skal gjøre rede for videre, har flere tros- og livssynssamfunn samarbeidet med DNK i utarbeidelsen av veiledningsmaterialet med sikte på å fremme utviklingshemmedes rett til fri religionsutøvelse.

\section{Norsk politikk om religionsutøvelse blant mennesker med utviklingshemming}

Det normative grunnlaget for Norges offentlige politikk når det gjelder rett til religionsutøvelse blant mennesker med utviklingshemming, er de internasjonale menneskerettighetene og det nasjonale lovverket som blant annet sikrer nasjonal implementering av dem. De fleste lover, regler og policydokumenter tar ikke spesifikt for seg de utviklingshemmedes religionsutøvelse, men er basert på den allmenne retten til fri religionsut$ø$ velse og forbud mot enhver form for diskriminering. Her skal jeg nevne de mest sentrale av disse dokumentene. Først vil jeg omtale den nasjonale menneskerettslovgivningen for deretter å gå over til de viktigste policydokumentene.

Norsk menneskerettslovgivning er bygget på Norges grunnlov og menneskerettsloven fra 1999 sammen med en rekke internasjonale konvensjoner, som FN-konvensjonen om sivile og politiske rettigheter (SP), FN-konvensjonen om økonomiske, sosiale og kulturelle rettigheter (ØSK), FN-konvensjonen om barnets rettigheter (BK), 
FN-konvensjonen om avskaffelse av alle former for diskriminering av kvinner (CEDAW) samt Den europeiske menneskerettskonvensjonen (EMK), som er inkorporert i menneskerettsloven (menneskerettsloven 1999).

Sammen med tanke-, ytrings- og samvittighetsfrihet står retten til fri religionsutøvelse sentralt blant menneskerettighetene. For eksempel slår EMK i artikkel 9.1 fast at «[e]nhver har rett til tankefrihet, samvittighetsfrihet og religionsfrihet; denne rett omfatter frihet til å skifte sin religion eller overbevisning, og frihet til ... å gi uttrykk for sin religion eller overbevisning, ved tilbedelse, undervisning, praksis og etterlevelse» (menneskerettsloven 1999, art. 9,1).

En sentral stilling har også lov om likestilling og forbud mot diskriminering (likestillings- og diskrimineringsloven), som ble vedtatt i 2017 og erstattet den tidligere diskriminerings- og tilgjengelighetsloven fra 2009. Mens den tidligere loven var rettet spesifikt mot diskriminering av mennesker med funksjonsnedsettelser, omhandler den nåværende loven også andre områder, som kjønn, etnisitet, religion, livssyn og funksjonsnedsettelse, der diskriminering skal bekjempes (likestillings- og diskrimineringsloven, 2017, $\$ 1$ ). Loven henviser imidlertid spesifikt til denne gruppen mennesker bare i kapittel 3, som handler om universell utforming og individuell tilrettelegging.

Normgivende dokumenter som spesifikt tar for seg mennesker med funksjonsnedsettelser, og som gjelder for Norge, er FNs standardregler for like muligheter for mennesker med funksjonshemming («standardreglene») og FN-konvensjonen om rettighetene til mennesker med nedsatt funksjonsevne (CRPD).

Standardreglene ble vedtatt av FNs generalforsamling 20. november 1993 (FN, 2001). Dette ikke er et bindende dokument, men reglene gir likevel en moralsk rettesnor og veiledning til retningslinjer for medlemsstater, og de er blitt anerkjent som viktige av flere norske regjeringer (Torgauten, 2010a, s. 55). Dokumentets regel nummer 12 omhandler eksplisitt religion og stadfester at medlemsstater, i samarbeid med religiøse ledere, bør bekjempe diskriminering og fremme deltakelse av mennesker med funksjonsnedsettelser i deres samfunns religiøse liv (FN, 2001). 
Neste skritt i kodifiseringsprosessen av rettighetene til mennesker med funksjonsnedsettelser på internasjonalt plan finnes i FN-konvensjonen om rettighetene til mennesker med nedsatt funksjonsevne (CRPD), vedtatt av FNs generalforsamling i 2006 (Barne-, likestillings- og inkluderingsdepartementet, 2013). Den ble ratifisert av Norge i 2013 og ble erklært som en rettesnor for landets offisielle politikk overfor mennesker med utviklingshemming (NOU 2016: 17).

I motsetning til standardreglene nevner ikke CRPD retten til fri religionsutøvelse, heller ikke religion som sådan (Barne-, likestillings- og inkluderingsdepartementet, 2013). I artikkel 30 stadfester imidlertid konvensjonen retten til både tilgang til kultur og utvikling av eget kreativt potensial på lik linje med andre (Barne-, likestillings- og inkluderingsdepartementet art.30). I sin fortale bygger dessuten konvensjonen eksplisitt på internasjonale menneskerettighetskonvensjoner som ØSK og SP (Barne-, likestillings- og inkluderingsdepartementet 2013, fortale b, d.), og anerkjenner menneskerettighetenes udelelige karakter (Barne-, likestillings- og inkluderingsdepartementet, fortale c.). Selv om konvensjonen ikke nevner religion eksplisitt, gir den dermed likevel rom for å fremme rett til religionsutøvelse.

I stortingsmelding nr. 25, Mestring, muligheter og mening, tar helse- og omsorgskomiteen opp fremtidens sentrale omsorgsutfordringer (Helseog omsorgskomiteen, 2007). I denne sammenheng understreker komiteens flertall at:

[...] mennesker med psykisk utviklingshemning må sikres å kunne utøve sin tro eller sitt livssyn. Dette området kan lett bli oversett av personalet som yter omsorgstjenester. Mennesker med psykisk utviklingshemning eller som har nedsatt kommunikasjonsevne, har ikke samme mulighet til å formidle sine behov for tros- og livssynsutøvelse eller til å praktisere sin tro/sitt livssyn som andre uten bistand fra omsorgspersonell. (s. 46)

Komiteens flertall har med dette plassert ansvaret for sikring av retten til religionsutøvelse («tros- og livssynsutøvelse») hos tjenesteyterne i samarbeid med tjenestemottakere og deres pårørende (s. 46), og det er presisert at de enkelte tjenestemottakernes religiøse behov skal nedfelles i en individuell plan (s. 46). 
I rundskriv I-6/2009 Retten til tros- og livssynsutøvelse fra Helse- og omsorgsdepartementet blir landets kommuner pålagt å sikre at alle som er avhengig av kommunale helse- og omsorgstjenester, skal få ivaretatt sine religiøse og åndelige behov «i tråd med grunnlovfestede bestemmelser om religionsfrihet og ytringsfrihet» (Helse- og omsorgsdepartementet, 2009).

I 2016 avga Barne- og likestillingsdepartementet utredningen $P a ̊ l i k$ linje: Åtte løft for å realisere grunnleggende rettigheter for personer med utviklingshemming. Dette dokumentet er ment å være det sentrale styringsprogrammet for den norske statens politikk overfor mennesker med utviklingshemming. Utredningen tar utgangspunkt i de rettighetene som er nedfelt i CRPD, og den undersøker status for hvordan disse rettighetene blir realisert, samt drøfter tiltak for oppfyllelse av konvensjonen.

På samme måte som i CRPD er ikke religion tatt med i utredningen. Dokumentets kapittel 15 heter «Fritid» og omhandler status for og utfordringer forbundet med fritidstilbud for mennesker med utviklingshemming samt deres deltakelse i dem (NOU 2016: 17, s. 152). Utredningens forfattere definerer fritidsaktiviteter som «alt fra kulturopplevelser, idrettsaktiviteter eller hobbyvirksomheter, og kan være organisert elle uorganisert» (s. 152).

Ved å fremme mulighetene for diverse fritidsaktiviteter blant utviklingshemmede understreker utredningen disse aktivitetenes potensial for utvikling av sosiale ferdigheter og tilfredstillelse av sosiale behov (s. 152). I denne sammenhengen kan det nevnes at en del forskning om utviklingshemmedes religionspraksis kan tyde på at organisert religiøs aktivitet, slik som kirkebesøk, kan ha stor betydning nettopp som dekning av behov for sosialt samvær (se f.eks. Minton \& Dodder, 2003). Andre aspekter ved utviklingshemmedes religiøse og åndelige behov er derimot utelatt fra utredningen.

Som jeg har vist, tar ikke de sentrale norske normgivende dokumentene som legger føringer for politikk overfor mennesker med utviklingshemming, opp religion som et særskilt område der det utøves et generelt vern av retten til religionsutøvelse. Dette er en åpenbar mangel. De behandler likevel et bredt og sammensatt spekter av livsområder, inkludert områder 
hvor man i det minste kan plassere religionsutøvelse rent funksjonelt, for eksempel innenfor kultur og fritid. Det er også viktig å anerkjenne at dokumentenes oppmerksomhet på styrking av de utviklingshemmedes medborgerskap og selvbestemmelse representerer et viktig skritt i retning av å styrke disse menneskenes aktørskap og myndighet, også på det religiøse plan.

\section{Den norske kirkes offisielle ståsted overfor utviklingshemmedes religiøse behov}

I senere år har Den norske kirke vedtatt en rekke dokumenter som markerer Kirkens offisielle ståsted overfor mennesker med utviklingshemming og deres religiøsitet. Siden dette trossamfunnet fortsatt beholder både en særskilt status i Grunnloven og en bred forankring blant befolkningen, er det etter min mening viktig å ta opp Kirkens offisielt vedtatt politikk overfor utviklingshemmede.

I møtet med disse menneskene har DNK engasjert også andre trosog livssynssamfunn. Etter initiativ fra Kirkerådet ble det i 2007 nedsatt en arbeidsgruppe med representanter fra noen av disse, det vil si Norsk Forbund for Utviklingshemmede, Borg bispedømme, Den katolske kirke og Frikirkelig studieforbund. Gruppen fikk i oppdrag å utarbeide veiledningsstoff med sikte på å fremme inkludering og deltakelse av utviklingshemmede i tros- og livssynssamfunn. På denne bakgrunn utga Kirkerådet, Norges Kristne Råd og Samarbeidsrådet for tros- og livssynssamfunn et veiledningshefte med tittelen Deltakelse og tilhørighet. Inkludering av mennesker med utviklingshemning i tros- og livssynssamfunn (Kirkerådet, Norges Kristne Råd \& Samarbeidsrådet for trosog livssynssamfunn, 2009).

Med utgangspunkt $i$ at menneskeretten til fri religionsutøvelse er nedfelt i Grunnlovens paragraf 2 og i artikkel 18 i FNs konvensjon om sivile og politiske rettigheter, og $\mathrm{i}$ at diskriminering på grunn av nedsatt funksjonsevne er forbudt etter norsk lovgivning ${ }^{2}$ og FNs standardregler, slår

2 På det tidspunktet da brosjyren ble publisert (2009), var lov om forbud mot diskriminering på grunn av nedsatt funksjonsevne (diskriminerings- og tilgjengelighetsloven) fortsatt i kraft. 
heftets forfattere fast at alle tros- og livssynssamfunn er forpliktet til å sikre deltakelse og tilhørighet for mennesker med utviklingshemming i sine rekker (Kirkerådet et al., 2009). Forfatterne understreker at selv om det er bred enighet om likt menneskeverd for alle blant forskjellige religiøse samfunn, «viser erfaringene at det er behov for å se om praksisen samsvarer med læren» (Kirkerådet et al., 2009). De understreker at det er avgjørende å gi mennesker med utviklingshemming muligheter til å realisere sine rettigheter.

Ved å understreke alle menneskers likeverd uansett funksjonsnivå tar heftets forfattere tydelig avstand fra enhver form for paternalisme: «Vi må heller ikke bare være 'snille' med mennesker med utviklingshemming, men også stille krav til dem - som til alle andre. ... Vi er alle medmennesker. Ingen er et 'veldedighetsobjekt' som vi skal gjøre noe for» [min utheving] (Kirkerådet et al., 2009).

Materialet tydeliggjør også at mennesker med utviklingshemming har autonomi i religiøse spørsmål på lik linje med alle andre:

Ikke alle mennesker med utviklingshemning ønsker å være aktive i tros- eller livssynssamfunn. ... [De] har ikke bare rett til å bli invitert med i ulike fellesskap og aktiviteter. De har også rett til selv å velge hvordan de skal delta. (Kirkerådet et al., 2009)

Heftets forfattere understreker at for å sikre tjenestemottakernes rettigheter er det nødvendig med samhandling mellom tjenestemottakerne, tjenesteyterne og pårørende. I flere sammenhenger vil pårørende kunne være de enkeltes talspersoner. Samtidig stiller forfatterne også en rekke krav til dem, blant annet ved å advare mot å overse - eller til og med benekte - utviklingshemmedes evner til å være religiøse subjekter: «En diskusjon om hvorvidt den enkelte selv er i stand til å ha en oppfatning [om sine religiøse behov] og om det i så fall skal tas hensyn til den, bør unngås» (Kirkerådet et al., 2009).

I november samme år kom Kirkerådet med uttalelsen «Likeverd, inkludering, tilrettelegging. Den norske kirkes betjening av mennesker med utviklingshemning» (Kirkerådet, 2009). På bakgrunn av DNKs selvforståelse som «en bekjennende, misjonerende, tjenende og åpen folkekirke» slår rådet $\mathrm{i}$ dette dokumentet fast at siden kirken representerer 
et felleskap av de døpte med Gud og hverandre og er bygget på tanken om de døptes likeverd, har «[m]ennesker med utviklingshemming ... samme mulighet til å delta i kirkens felleskap som alle andre» (Kirkerådet, 2009).

Dokumentet tar utgangspunkt $i$ at troen er en gave fra Gud, gitt uavhengig av intellektuelle evner eller kommunikasjonsferdigheter. Denne påstanden er helt sentral for den kristne trosforståelsen. Ved å vedkjenne seg den tar kirken likevel avstand fra den tenkemåten som i lengre tid har preget det lutherske religiøse liv, nemlig at det legges vekt på betydningen av en forståelse av og kunnskap om troens innhold. Historisk har dette gitt seg utslag i blant annet eksklusjon av utviklingshemmede fra konfirmasjonen, siden denne har vært knyttet til tilegnelse av grunnleggende kristendomskunnskaper (Dahle, 2010, s. 34).

Et interessant poeng i Kirkerådets uttalelse er den spesielle rollen som tilkjennes kirken i forsvaret av ikke bare de egne medlemmenes, men alle utviklingshemmede borgeres rett til fri religiøs og livssynsorientert tilknytning:

Den norske kirke har her en dobbel forpliktelse, å forsvare retten til fri religionsutøvelse for mennesker med utviklingshemning i andre religioner og trossamfunn, og å samtidig sikre at sine egne medlemmer med utviklingshemning får reell mulighet til trosutøvelse alene og i fellesskap med andre. (Kirkerådet, 2009)

Med denne dobbelte rollen som både et inkluderende fellesskap for alle døpte og en tydelig stemme som forsvarer retten til religionsutøvelse for alle mennesker med utviklingshemming, har kirken tatt tydelig stilling til dem som aktører, også på området religion og livssyn.

I et vedtak som fulgte i 2012, tok Kirkemøtet utgangspunkt i tesene i Kirkerådets uttalelse fra 2009, men spesifiserte dem i mer praktisk retning. Ved å ta utgangspunkt i premisset at det er kirkens oppgave å «inkludere mennesker med utviklingshemming ut fra deres egne forutsetninger og på en likeverdig måte», pålegger Kirkemøtet kirkens organer å sikre denne muligheten (vedtak 4) (Kirkjemøtet, 2012, s. 2). Blant annet ber Kirkemøtet bispedømmerådene sørge for at menighetene har tilgang til personer med nødvendig kompetanse «for å sikre tros- og livssynsutøvelse for mennesker med utviklingshemming» (vedtak 5) (s. 2). Kirkemøtet presiserer også at dette må skje i samarbeid med kommunene 
og involvere pårørende, verger og alle andre som er med på å fremme utviklingshemmedes interesser (vedtak 5) (s. 2). Kirkemøtet fremhever også viktigheten av å heve kunnskaps- og kompetansenivået på alle områder i kirken (vedtak 4) (s. 2) samt legger ansvar på menighetene for å gjennomføre holdningsskapende arbeid (vedtak 7) (s. 2).

Som jeg har forsøkt å vise, har Den norske kirke i sine policydokumenter tatt et klart standpunkt for å anerkjenne ikke bare religiøse behov hos mennesker med utviklingshemming, men også deres aktørskap som religiøse subjekter, deres menneskeverd og likeverd som medborgere. Med dette har kirken foretatt et klart brudd med den paternalistiske veldedighetstankegangen som betrakter mennesker med utviklingshemming som omsorgsobjekter. Kirkens offisielle standpunkt utgjør med dette et viktig supplement til den juridiske og politiske diskursen om mennesker med utviklingshemming, der den religiøse siden til en viss grad blir neglisjert.

Samtidig er det viktig å understreke at jeg her kun har drøftet kirkens stilling slik den gjenspeiles i offisielt vedtatte dokumenter. Det at disse policydokumentene er vedtatt, betyr ikke at selve politikken er implementert. Selv om kirkens aktuelle praksis overfor mennesker med utviklingshemming er lite utforsket, er det tydelig at en del utfordringer består. For eksempel stiller kirken fortsatt krav til kandidater til prestetjeneste som kan ekskludere personer med fysiske og psykiske funksjonsnedsettelser (Lid, 2017, s. 34).

\section{Religionens plass i retningslinjene for utdanning av tjenesteytere}

Som det fremgår av de retningslinjene som er drøftet ovenfor, er en stor del av ansvaret for tilretteleggingen av religions- og livssynsutøvelse for mennesker med utviklingshemming plassert på tjenesteytere, inkludert faglærte utøvere av omsorgsyrker. Deres kompetanse om religion, livssyn og rettigheten til religionsutøvelse samt kunnskap om utviklingshemmedes religiøse behov blir dermed sentral.

Det er derfor viktig å kaste et blikk på de retningsgivende dokumentene som fastsetter utdanningsstandarder for helse- og omsorgsyrker 
rettet mot arbeid med mennesker med utviklingshemming, for å se hvilken plass de nevnte kompetanseområdene har. Dette gjelder først og fremst rammeplanen for vernepleierutdanning, fordi dette yrket står sentralt innenfor nettopp denne formen for omsorgsarbeid.

Rammeplanen for vernepleierutdanning, fastsatt av Utdannings- og forskningsdepartementet i 2005, inneholder en del som er felles for alle utdanningene innen helse- og sosialfag, samt en spesifikk del for vernepleierutdanning (Utdannings- og forskningsdepartementet, 2005, s. 3).

Religion er ikke nevnt, verken i fellesdelen eller i den delen som er spesifikk for vernepleierutdanningen. Ett av utdanningsmålene i fellesdelen sier imidlertid at studentene skal kunne vise «et helhetlig syn på mennesket, vise respekt for menneskets integritet og rettigheter og ivareta brukernes autonomi og rett til selvbestemmelse» (Utdanningsog forskningsdepartementet 2005, s. 3). Studentene skal også «kunne kommunisere med mennesker med ulik etnisk, religiøs og kulturell bakgrunn» (s. 4). I den utdanningsspesifikke delen presiseres det at «vernepleiere skal ... møte brukere med empati og respekt ut fra perspektivet om likeverd, uavhengig av alder, kjønn, kultur, livssyn og virkelighetsoppfatning» (s. 5).

Når det gjelder rammeplanens faglige innhold, forekommer det heller ingen fag som tilbyr fordypning i religions-, livssyns- eller åndelighetsproblematikk. Det angis imidlertid at vernepleierstudenter skal gjennomgå studier i sosiologi og sosialantropologi, noe som er ment å gi kunnskap om blant annet «kulturelle verdier, normer, levevilkår og menneskerettigheter» (s. 7).

Fra og med studieåret 2020-2021 avløses imidlertid denne rammeplanen av et nytt system av retningslinjer for helse- og sosialfaglige utdanninger, styrt av forskrift om felles rammeplan for helse- og sosialfagutdanninger, kunngjort av Kunnskapsdepartementet 6. september 2017 (forskrift om felles rammeplan for helse- og sosialfagutdanninger, 2017; Kunnskapsdepartementet, 2017) ${ }^{3}$

3 Ifølge forskriftens paragraf 1 og 5 kan utdanningsinstitusjoner følge denne fra høsten 2019. Fra studieåret 2020-2021 blir forskriften obligatorisk for alle institusjoner. Den gamle rammeplanen oppheves fullstendig i 2026. 
Sammenliknet med rammeplanen for vernepleierutdanning fra 2005 er de nye såkalte retningslinjer i det nye systemet for styring i helse- og sosialfagutdanninger - vernepleierutdanningen («retningslinjer») (Kunnskapsdepartementet, 2017) tydeligere når det gjelder kompetanse i religions-, tros- og livssynstematikk. Ifølge dem skal den fremtidige yrkesutøveren ha

bred kunnskap om inkludering, likestilling og ikke-diskriminering, uavhengig av kjønn, etnisitet, religion og livssyn, funksjonsnedsettelse, seksuell orientering, kjønnsidentitet, kjønnsuttrykk og alder, slik at kandidaten bidrar til å sikre likeverdige tjenester for alle grupper i samfunnet ... [samt] har bred kunnskap om konvensjoner, lover, regler og for å sikre funksjonshemmedes rettigheter. (s. 3)

I tillegg til dette understreker retningslinjenes kapittel VI («Vernepleiefaglig arbeid og profesjonens arbeidsprosesser») at en yrkesutøver av vernepleiefaget skal ha god kommunikasjons-, relasjons- og kulturkompetanse og kunne bruke den ved planlegging og gjennomføring av samhandling med blant annet brukere og pårørende (s. 7). Dokumentet fremhever også tydelig at målet med profesjonsutdanningen er å fremme «selvbestemmelse, deltakelse, mestring, helse og livskvalitet» (s. 1).

Selv om retningslinjene inkluderer religion, skiller de ikke ut denne tematikken som et eget kunnskapsområde, men knytter den til likestilling og ikke-diskriminering på den ene siden (kapittel III) og kulturkompetanse på den andre (kapittel VI). Det fremgår også klart at sammenlignet med rammeplanen legger dette dokumentet mer vekt på likestilling og integrering.

Både rammeplanen og retningslinjene er tydelige i sin vektlegging av et helhetlig menneskesyn og fremheving av brukernes autonomi og medbestemmelse. De legger også opp til at fremtidige yrkesutøvere skal kunne vise kulturkompetanse og etiske holdninger når det gjelder inkludering, ikke-diskriminering og deltakelse. Ved å unnlate å presisere spesielle kompetanser innen denne tematikken er styringsdokumentene samtidig ganske fleksible når det gjelder hvor stor vekt det skal legges på den. Slik blir dette tydeligvis opp til de enkelte utdanningsinstitusjonene. 


\section{Oppsummering}

Rettighetene til mennesker med utviklingshemming har de senere årene blitt både anerkjent og nedfelt i konvensjoner og lovgivning, både på internasjonalt og nasjonalt plan. Det sentrale styrende dokumentet på dette planet internasjonalt, CRPD, ble ratifisert av Norge i 2013 og har dermed blitt tatt i norsk lovgiving. Selv om denne konvensjonen ikke tar opp religion per se, er den godt forankret i en menneskerettslig kontekst, hvor retten til fri religionsutøvelse og forbud mot alle former for diskriminering står helt sentralt.

I de av statens mer underordnede policydokumenter som er vedtatt for å realisere utviklingshemmedes rettigheter, blir dette området viet relativt ubetydelig oppmerksomhet. Spesielt gjelder dette det mest sentrale av disse dokumentene, NOU 2016: 17 På lik linje. I tillegg til at verken religion, tro eller livssyn er nevnt $i$ utredningen, er det mest nærliggende begrepet - kulturlivet - omtalt tilnærmet i forbifarten i tilknytning til temaområdet «fritid». Til tross for sitt progressive preg kan utredningen dermed kritiseres for å neglisjere et viktig aspekt ved menneskets tilværelse som ikke kan reduseres til fritidssysler.

Denne mangelen gjelder på flere måter også de offisielle retningslinjene for profesjonsutdanningen, men på grunn av deres vektlegging av et holistisk menneskesyn og kulturell og menneskerettslig kompetanse kan man ikke si at de overser det religiøse og livssynsrelaterte aspektet fullstendig.

Til tross for denne unnlatelsen ser imidlertid den offisielt vedtatte norske politikken, som er basert på et solid grunnlag av internasjonale menneskerettigheter og de uttalte forpliktelse til rett til fri religionsutøvelse og ikke-diskriminering, ut til å ha gjort betydelige fremskritt også når det gjelder utviklingshemmedes religiøsitet.

På bakgrunn av dette representerer DNKs vedtatte politikk, i det minste slik den er uttrykt i offisielle dokumenter, et viktig supplement og korrektiv til denne mangelen. Selv om den ikke lenger er Norges statskirke, har dette trossamfunnet, som de fleste nordmenn fortsatt føler tilhørighet til, på mange måter gått i spissen for å fremme ikke bare formelle rettigheter, men også reelle muligheter til fri religionsutøvelse for mennesker med utviklingshemming. I dette baserer kirken seg på et syn der personer i denne gruppen ikke betraktes som passive objekter for veldedighet, men som aktivt handlende subjekter - også på det religiøse planet. 


\section{Referanser}

Barne-, likestillings og inkluderingsdepartementet. (2013). Konvensjon om rettighetene til mennesker med nedsatt funksjonsevne. Hentet fra https://www. regjeringen.no/globalassets/upload/bld/sla/funk/konvensjon_web.pdf

Berger, P. L. (1967). The sacred canopy. Elements of a sociological theory of religion. Garden City, New York: Doubleday \& Company, Inc.

Berger, P. L. (1999). The desecularization of the world: A global overview. I P. L. Berger (Red.), The desecularization of the world. Resurgent religion and world politics (s. 1-18). Grand Rapids: William B. Eerdmans Publishing.

Botvar, P. K. (2010). Endringer i nordmenns religiøse liv. I P. K. Botvar \& U. Schmidt (Red.), Religion i dagens Norge. Mellom sekularisering og sakralisering (s. 11-24). Oslo: Universitetsforlaget.

Casanova, J. (1994). Public religions in the modern world. Chicago, IL: University of Chicago Press.

Dahle, S. (2010). Et historisk riss. I S. Dahle \& T. I. Torgauten (Red.), Utviklingshemming og tros- og livssynsutøvelse. Rettigheter og tilrettelegging (s. 33-40). Oslo:

Universitetsforlaget.

Davie, G. (2002). Europe: The exceptional case. Parameters of faith in the modern world. London, England: Darton, Longman and Todd.

Davie, G. (1999). Europe: The exception that proves the rule? I P. L. Berger (Red.), The desecularization of the world. Resurgent religion and world politics (s. 65-83). Grand Rapids, MI: William B. Eerdmans Publishing.

Dobbelaere, K. (1981). Secularization: A multi-dimensional concept. Trend rapport. Current Sociology, 29(2). https://doi.org/10.1177\%2Foo1139218102900203

Dobbelaere, K. (2002). Secularization. An analysis at three levels. Brussel: Peter Lang. Ellingsen, K. E. \& Sandvin, J. T. (2014). Utviklingshemming: funksjonsnedsettelse, miljøkrav og samfunnsreformer. I K. E. Ellingsen (Red.), Utviklingshemming og deltakelse (s. 11-31). Oslo: Universitetsforlaget.

FN (2001). Standardregler for like muligheter for mennesker med funksjonshemming. Oslo: Sosial- og helsedepartementet.

Gorski, P. S. \& Altinordu, A. (2008). After secularization? Annual Review of Sociology 34, 55-85. https://doi.org/10.1146/annurev.soc.34.040507.134740

Grunnloven. (2018). Kongeriket Norges Grunnlov (LOV-1814-05-17) Hentet fra https://lovdata.no/dokument/NL/lov/1814-05-17-nn?q=Grunnlov

Gustavsson, A. \& Nyberg, C. (2014). Den levde deltakelsen. I K. E. Ellingsen (Red.), Utviklingshemming og deltakelse (s. 91-119). Oslo: Universitetsforlaget.

Helse- og omsorgsdepartementet. (2009). Rett til egen tros- og livssynsutøvelse (Rundskriv I-6/2009). Hentet fra https://www.regjeringen.no/no/dokumenter/i62009-rett-til-egen-tros--og-livssynsu/id587577/ 
Helse- og omsorgskomiteen. (2007). Mestring, muligheter og mening (Innst. S. nr.150 [2006-2007]). Hentet fra https://www.stortinget.no/no/Saker-og-publikasjoner/ Publikasjoner/Innstillinger/Stortinget/2006-2007/inns-200607-150/?lvl=0

Järvinen, M. \& Mik-Meyer, N. (2003). At skabe en klient (s. 9-29). København: Hans Reitzels Forlag.

Jenkins, R. (2008). Social identity (3. utg.). London: Routledge.

Kirkerådet. (2009). Likeverd, inkludering, tilrettelegging. Uttalelse fra Kirkerådet 15. november 2009. Hentet fra https://kirken.no/globalassets/bispedommer/ borg/dokumenter/tema/inkludering/heftet-likeverd-inkluderingtilrettelegging.pdf

Kirkerådet, Norges Kristne Råd \& Samarbeidsrådet for tros- og livssynssamfunn. (2009). Deltakelse og tilhørighet. Inkludering av mennesker med utviklingshemning i tros- og livssynsamfunn. Hentet fra http://www.deltakelse.no/file.php?fid=95

Kirkemøtet. (2004) Den norske kirkes identitet og oppdrag. Uttalelse fra Kirkemøtet 2004. Hentet fra https://kirken.no/globalassets/kirken.no/om-kirken/slik-styreskirken/planer-visjonsdokument-og-strategier/identitet_oppdrag_2004_bokmaal.pdf

Kirkjemøtet. (2012). Likeverd, inkludering og tilrettelegging. Mennesker med utviklingshemming i Den norske kirke. Vedtak av Kirkemøtet 2012. Hentet fra https://kirken.no/globalassets/kirken.no/migrering/km_9_12_likeverd_ merknad_vedtak.pdf

Kultur- og kirkedepartementet. (2008). Staten og Den norske kirke (St.meld. nr. 17 [2007-2008]) Oslo: Kultur- og kirkedepartementet. Hentet fra https://www. regjeringen.no/no/dokumenter/stmeld-nr-17-2007-2008-/id507168/

Kunnskapsdepartementet. (2017). Forskrift om felles rammeplan for helse- og n sosialfagutdanninger (FOR-2017-09-06-1353). Hentet fra https://lovdata.no/ dokument/SF/forskrift/2017-09-06-1353

Kunnskapsdepartementet. (2017). Retningslinjer i et nytt system for styring av læringsutbytte i helse- og sosialfagutdanninger - vernepleierutdanningen. Hentet fra https://www.regjeringen.no/contentassets/874ef4e2da2e401a8eo6de7da1c83e65/ utkast-til-retningslinje-for-vernepleierutdanningen.pdf

Lid, I. M. (2017). Challenges from the UN Convention on the Rights of Persons with Disabilities: Access to theology and church practice in the Church of Norway. Journal of Disability \& Religion 21(1), 30-42. https://doi.org/10.1080/23312521.2016. 1270176

Likestillings- og diskrimineringsloven. (2017). Lov om likestilling og forbud mot diskriminering (LOV-2017-12-19-115). Hentet fra https://lovdata.no/dokument/ NL/lov/2017-06-16-51?q=Likestillings-\%20og\%2odiskrimineringsloven

Menneskerettsloven. (1999). Lov om styrking av menneskerettighetenes stilling i norsk rett (LOV-2014-05-09-14). Hentet fra https://lovdata.no/dokument/NL/ lov/1999-05-21-30?q=Menneskerettighetsloven 
Minton, C. A. \& Dodder, R. A. (2003). Participation in religiouss by people with developmental disabilities. Mental Retardation, 41(6), 430-9.

NOU 2016: 17. (2016). På lik linje. Åtte løft for å realisere grunnleggende rettigheter for personer med utviklingshemming. Hentet fra https://www. regjeringen.no/contentassets/bobaf226586543ada7c530b4482678b8/no/pdfs/ nou2016201600170oodddpdfs.pdf

Torgauten, T. I. (2010a). Lovverk og offentlige føringer. I S. Dahle \& T. I. Torgauten (Red.), Utviklingshemming og tros- og livssynsutøvelse. Rettigheter og tilrettelegging (s. 47-57). Oslo: Universitetsforlaget.

Turner, S., Hatton, C., Shah, R., Stansfield, J. \& Rahim, N. (2004). Religious expression amongst adults with intellectual disabilities. Journal of Applied Research in Intellectual Disabilities, 17, 161-171.

Sandvin, J. T. (2014). Utviklingshemmet av hvem? I K. E. Ellingsen (Red.), Utviklingshemming og deltakelse (s. 91-119). Oslo: Universitetsforlaget.

Sango, P. N. \& Forrester-Jones, R. (2017). Intellectual and developmental disabilities, spirituality and religion: A systematic review 1990-2015. Journal of Disability \& Religion, 21(3), 280-295, https://doi.org/10.108o/23312521.2017.1317224

Schmidt, U. (2010a). Religion i dagens Norge: Sekularisert? Privatisert? Pluralisert? I P. K. Botvar \& U. Schmidt (Red.), Religion i dagens Norge. Mellom sekularisering og sakralisering. Oslo: Universitetsforlaget.

Schmidt, U. (2010b). Norge: et religiøst pluralistisk samfunn? I P. K. Botvar \& U. Schmidt (Red.). Religion i dagens Norge. Mellom sekularisering og sakralisering (s. 25-43). Oslo: Universitetsforlaget.

Shogren, K. A. \& Rye, M. S. (2005). Religion and individuals with intellectual disabilities. Journal of Religion, Disability \& Health, 9(1), 29-53. https://doi. org/10.1300/Jo95vo9no1_03

Swinton, J. (2002). Spirituality and the lives of people with learning disabilities. Tizard Learning Disability Review, 7(4), 29-35. https://doi.org/10.1108/13595474200200037

Swinton, J. (2011). Who is the God we worship? Theologies of disability; Challenges and new possibilities. International Journal of Practical Theology, 14, 273-307. https://doi.org/10.1515/ijpt.2011.020

Utdannings- og forskningsdepartementet. (2005). Rammeplan for vernepleierutdanning. Hentet fra https://www.regjeringen.no/globalassets/ upload/kilde/kd/pla/2006/ooo2/ddd/pdfv/269377-rammeplan_for_ vernepleierutdanning_05.pdf

Zuckerman, P. (2009). Why are Danes and Swedes so irreligious? Nordic Journal of Religion and Society, 22(1), 55-69. Hentet fra https://www.idunn.no/file/ ci/66930069/Why_Are_Danes_And_Swedes_So_Irreligious.pdf 



\title{
Inkludering og tilrettelegging i Den norske kirkes trosopplæring
}

\author{
Inger Marie Lid
}

VID vitenskapelige høgskole

\begin{abstract}
This article presents results from a project that studies inclusion and accommodation in Norwegian faith education as organized under the Plan for Faith Education by the Church of Norway. Norwegian faith education aims at educating children and young persons from 0 to 18 years. All children and young persons who wish to take part in this should be included and accommodated. However, there are barriers experienced by persons with disabilities hampering participation on an equal basis. Based on qualitative interviews in four congregations, the article discusses how inclusion and accommodation is practiced in the confirmation program, and what barriers hamper participation. The results indicate that the congregations wish to include all, but need more knowledge on how to reach the aim of inclusion and accommodation. The barriers are conceptual, attitudinal and material. The practice in faith education thus is to some extent segregational.
\end{abstract}

Keywords: inclusion, accommodation, confirmation, disability, Martha Nussbaum

\section{Innledning}

Plan for trosopplaring, Gud gir - vi deler ble vedtatt på Kirkemøtet i 2009. Selve planen ble publisert i januar 2010 og vektlegger inkludering og tilrettelegging (Kirkerådet, 2010). Forarbeidet startet allerede i 2003, da reformen av kirkens trosopplæring ble vedtatt av Stortinget. I perioden 2004-2008 ble det gjort forsøk lokalt med å etablere en systematisk opplæring i kirkens tro for døpte mellom o og 18 år. Barn og unge med

Sitering av denne artikkelen: Lid, I. M. (2020). Inkludering og tilrettelegging i Den norske kirkes trosopplæring. I I. M. Lid \& A. R. Solevåg (Red.), Religiøst medborgerskap: Funksjonshemming, likeverd og menneskesyn (Kap. 2, s. 49-68). Oslo: Cappelen Damm Akademisk. https://doi.org/10.23865/ noasp.10o.ch2

Lisens: CC BY-NC-ND 4.0. 
nedsatt funksjonsevne skal kunne oppleve tilhørighet og ha mulighet til deltakelse i fellesskapet (Kirkerådet, 2010, s. 18).

Dette kapitlet, som handler om likeverd og tilgjengelighet, undersøker i hvilken grad trosopplæringen er tilrettelagt slik at barn og unge med nedsatt funksjonsevne har likeverdig mulighet for deltakelse. Jeg vil trekke inn teoretiske perspektiver på sårbarhet og medborgerskap, representert ved Martha Nussbaum. Nussbaum tar som utgangspunkt at variasjoner i funksjonsevne er en del av menneskelig mangfold, som samfunnet må tilrettelegge for slik at alle får mulighet til å leve i samsvar med den verdigheten mennesket har (Nussbaum, 2007; Lid, 2012).

Dette kapitlet bygger på et prosjekt finansiert av trosopplæringsreformen, med tittelen «Inkludering og tilrettelegging i trosopplæringen, hva er praksis?» og ble gjennomført i 2014-2017. Hensikten med prosjektet var å undersøke hvordan inkludering og tilrettelegging ivaretas i den delen av trosopplæringen som flest deltar i, nemlig konfirmasjonen. Konfirmasjonsundervisningen gjennomføres når konfirmanten går i niende klasse.

Kapitlet begynner med en kort presentasjon av prosjektet. Deretter utdypes barrierer, som hindrer deltakelse, medborgerskap og teoretiske perspektiver på likeverd og tilrettelegging. Studiens materiale presenteres, og i siste del diskuterer jeg tre temaer som fremsto som viktige, og drøfter disse i lys av målsettingen om at Den norske kirke skal være en raus og inkluderende folkekirke.

\section{Presentasjon av trosopplæringsprosjektet}

Inkludering og tilrettelegging er blant trosopplæringsplanens sentrale dimensjoner (Kirkerådet, 2010, s. 28). Det å ivareta inkludering og tilrettelegging på en slik måte at barn og unge opplever likeverdige muligheter for deltakelse, krever kunnskap. I dette prosjektet har jeg undersøkt hvor kirken henter kunnskap om inkludering og tilrettelegging fra, og i hvilken grad konfirmanter og ansatte ivaretar, erfarer og praktiserer inkludering og tilrettelegging. Prosjektet er kvalitativt, og materialet er intervjusamtaler med ansatte som har ansvar for inkludering og tilrettelegging i trosopplæringen i fire menigheter. Menighetene er ulike men 
tilhører alle Den norske kirke. Tre av menighetene er bymenigheter, mens en av menighetene ligger i distriktet. Jeg har intervjuet de i menigheten med lederansvar (som oftest sogneprest og daglig leder) og ansatte i menigheten med ansvar for konfirmantundervisningen (i to av menighetene var dette en prest, og i to av menighetene var det en trosopplærer). Disse intervjuene er en form for ekspertintervjuer fordi intervjupersonene ble valgt ut fra en strategisk inkludering basert på deres ansvarsoppgaver (Bogner, Littig \& Menz, 2009).

Det ble gjort intervjuer med elleve ansatte fordelt på fire menigheter i og utenfor Oslo. Intervjuene ble tatt opp på diktafon og transkribert i etterkant. Alle intervjuene ble gjennomført som individuelle kvalitative intervjuer (Kvale, 2007). I tillegg gjennomførte jeg et gruppeintervju med konfirmanter i to av menighetene. Ett av disse intervjuene er transkribert. Barn og unge regnes som sårbare i forskningssammenheng, og jeg registrerte derfor ingen personopplysninger (Lund, 2011). Trosopplæringsplanen og enkelte lokale planer ble analysert som tilleggsdata. Resultatene fra intervjusamtalene og planene ble analysert basert på en tematisk analyse av innholdet (Tjora, 2017). Temaene inkludering og tilrettelegging har vært styrende og har også vært ledemotiv for lesing av plandokumentene.

\section{Deltakelseshemmende barrierer}

Mange av konfirmantene konfirmeres i sin lokale kirke og kjenner derfor hverandre fra skole og nabolag. Alle de fire menighetene hadde konfirmasjonsundervisning som omfattet ettermiddagsmøter og leir. Noen hadde møtene i hjemmene, mens de fleste møttes i kirkerommet eller i et annet av kirkens rom.

Barrierene som hindrer deltakelse kan handle om holdninger, om sosiale og materielle forhold og om teologi. Jeg vil rette søkelyset mot den materielle og romlige dimensjonen fordi personer med funksjonsnedsettelse ofte opplever fysiske og materielle barrierer for deltakelse, som beskrevet tidligere. I dette prosjektet ble derfor romlige forhold som for eksempel kirkerom og steder for sosiale møter og leir vektlagt på linje med teologiske temaer knyttet til for eksempel språk og gudsbilder. 
Romlige forhold omfatter sosiale praksiser, mens sted er fysiske arenaer der praksisene foregår. Som kroppslige individer er mennesker alltid et sted. Det er selve kroppsligheten som gjør at vi er på steder - vi kan ikke være på et sted uten å være kroppslige (Casey, 1997).

Universell utforming vektlegges i trosopplæringen. Ifølge Plan for trosopploering (Kirkerådet, 2010, s. 29) er universell utforming kirkens generelle ansvar. Det enkelte kirkelige fellesrådet har ansvar for at kirkebygg og lokaler kan benyttes av flest mulig. Slik situasjonen er i dag, er svært mange kirkebygg og bygg som brukes til leir, ikke universelt utformet. Det betyr at de kan mangle tilgang til toalett, soverom og fellesrom og rom for uteaktiviteter. Jo dårligere tilgjengeligheten er, desto større er behovet for oppfølging og individuell tilrettelegging.

Både leirsteder og kirkebygg er fysiske og arkitektoniske steder som gir rom for noen menneskers kropper, og som ekskluderer andre. Disse stedene kan representere hindringer for noen av konfirmantene. Kirkebyggene er bygd under andre plan- og byggeforskrifter enn dagens, og de har ofte både en utforming og en innredning som danner barrierer. Leirstedene er gjerne mindre arkitektonisk gjennomarbeidet, og de kan også representere barrierer i form av utilgjengelig plassering i terrenget eller utilgjengelige rom. Leirstedene som brukes, er ofte bygd ut fra tidligere tiders byggeforskrifter og $i$ en tid da samfunnet var mer segregert enn i dag.

\section{Betydningen av deltakelse}

Plan for trosopploring regulerer menighetenes trosopplæring som tilbys barn og unge i alderen o-18 år. Opplæringen i kristen tro knyttes til barns og unges livserfaring og livstolking og skal slik være gjenkjennelig for barna og ungdommene (Kirkerådet, 2010, s. 5).

Det å kunne være til stede sammen med andre og delta i en offentlig aktivitet som for eksempel trosopplæring, har i seg selv en politisk dimensjon. Når menneskers kropper samles, utøver de som samles, en pluralistisk performativ rett til å tre frem som mennesker og personer i nettopp denne konkrete sammenhengen (Butler, 2015, s. 11). Dette betyr at rommene som brukes til samlinger, må ta høyde for at de personene 
som samles, er kroppslige og forskjellige; vi mennesker skal kunne tre frem i fellesskap som kroppslig forskjellige personer. Overført til trosopplæringen kan vi si at hvis det ikke legges til rette for at alle barn og unge - med ulike sanse- og funksjonsevner - kan ta del i aktivitetene, ekskluderes noen fra disse sammenhengene. Dersom det ikke er mulighet for at for eksempel en konfirmant med syns- eller bevegelseshemming deltar i konfirmantundervisningen, blir vedkommende ekskludert.

Jan Grue, professor og forfatter, utga i 2018 en bok som omhandler hans eget liv som rullestolbruker fra han var barn. Boken er en intellektuell levnetsbeskrivelse. I boken gjennomtenker han de sosiale aspektene ved barrierer som hindret ham som barn i å delta på lik linje med sine venner. Ekskluderingen han beskriver, er sosiomateriell. Det følgende sitatet er fra en situasjon hvor Grue og vennene er ute og leker på en plass som er omkranset av en gressbakke:

Nede på den flate støvete midten av Eventyrplassen kjører jeg rundt, mens de andre guttene er oppe på de grønne gresskantene. ... De er der oppe og kan komme ned til meg, men de vil ikke, og jeg kan ikke komme opp til dem, uansett hvor sterkt jeg vil det. (Grue, 2018, s. 64)

Grue viser i denne barndomserindringen hvordan han opplevde ekskludering på mikronivå, ved at han helt konkret ikke hadde tilgang til høyden med «de grønne gresskantene» der vennene var. Opplevelsen uttrykker en form for sårbarhet som kan være vanskelig å dele med andre. Slike erfaringer er det flere som har, og derfor er det viktig å sette ord på erfaringen og slik gjøre dem språklige og mulig å dele med andre. Gjennom boken bidrar Grue til at sårbarheten som erfares, kan skrives inn i en felles sårbarhet som vi deler, og som samtidig er individuelt erfart.

I skildringen beskriver Grue erfaringen gjennom klangfarger av «skam og raseri og forurettelse» (Grue, 2018, s. 64). Slik viser han kompleksiteten i inkludering og ekskludering. Sitatet er produktivt for å forstå hvordan det kan oppleves for en ungdom som ser vennene gå til konfirmantundervisning i den lokale menigheten, men som selv må bli hjemme eller gå til en annen kirke fordi den lokale menigheten ikke er tilrettelagt. Ungdommen som ikke kan delta i aktiviteter som ikke er tilrettelagt, hindres i å tre frem som en av fellesskapet innenfor rammen av for eksempel 
konfirmantopplæringen. At erfaringen av et slikt hinder kan bidra til skamfølelse, raseri og forurettelse, indikerer at inkludering og ekskludering også har en etisk dimensjon.

I sin teori om rettferdighet fremhever Nussbaum to forhold som er av betydning. Det første er at selvrespekt har en sosial dimensjon, og det andre er at den enkelte skal ha mulighet til å påvirke sine omgivelser materielt (Nussbaum, 2007). Dette er to av flere muligheter et samfunn som ønsker å være rettferdig, skylder å yte for borgerne. Begge er viktige i en analyse av inkludering og tilrettelegging i trosopplæringen.

\section{Plan for trosopplæring lest i lys av inkludering og tilgjengelighet}

I dette prosjektet ble deltakelse forstått i et flerdimensjonalt perspektiv. Et flerdimensjonalt perspektiv omfatter både sosiale, romlige, etiske og teologiske forhold. Den norske kirke skal være en kirke for alle. Trosopplæringsplanen viser i kapittel fire til betydningen av at barn og unge skal kunne finne rollemodeller de kan identifisere seg med, og til at lederne i kirkens trosopplæring derfor må tilhøre begge kjønn. I planen mangler det en liknende refleksjon over ansettelse av personer med funksjonsnedsettelse. Kirken har få ansatte med funksjonsnedsettelse og har ikke arbeidet strategisk for å rekruttere søkere med nedsatt funksjonsevne (Lid, 2017).

Plan for trosopploering ble vedtatt i 2010. Ny gudstjenesteordning for Den norske kirke ble vedtatt på Kirkemøtet i 2011. ${ }^{1}$ Det betyr at planen for trosopplæring forholder seg til ordningen for gudstjenesten i Den norske kirke som var gjeldende i 2010. Planen vektlegger i sitt formål at den skal bidra til «kristen livstolkning og livsmestring», og at den skal «utfordre til engasjement og deltakelse i kirke og samfunnsliv» (Kirkerådet, 2010, s. 4). Imidlertid er det i trosopplæringsplanens innhold og oppbygging mange aktiviteter som kommer i tillegg til gudstjenestedeltakelse, slik at planen står i fare for å etablere en forventning til aktivitet som i seg selv kan være

1 https://kirken.no/nb-NO/om-kirken/slik-styres-kirken/kirkemotet/dokumenter_vedtak/kirkemotet-05.04.2011---10.04.2011-tonsberg/ 
ekskluderende på grunn av omfanget. Planen legger opp til timebasert aktivitet på de ulike alderstrinnene, med 50 timer $\mathrm{i}$ aldersgruppen $0-5$ år, 145 timer i barndomsårene (6-12 år) og 120 timer i ungdomsårene (13-18 år). 60 av disse 120 timene er knyttet til konfirmasjonstiden (Kirkerådet, 2010, s. 19-21). I alle disse periodene er det foreslått kjerneaktiviteter, som kan være for eksempel bibelkurs, overnatting i kirken og leir (Kirkerådet, 2010, s. 21). Trosopplæringsplanen er blitt evaluert uten at menighetenes oppøølging av inkludering er studert spesifikt (Botvar, Haakedal \& Kinserdal, 2013).

Planens høye aktivitetsnivå legger opp til en forståelse av deltakelse som aktiv deltakelse. En slik forståelse av deltakelse innebærer at man risikerer å legge listen for hvem som kan delta, så høyt at det enten blir behov for mange ledere, eller at flere av barna kan oppleve at deltakelsen ikke passer for dem. Et eksempel her er overnatting i kirken, som for noen barn er veldig spennende, men som andre barn kan oppleve som krevende. I konfirmasjonsopplegget er det særlig leiren som kan være utfordrende. Dette gjelder både for menighetene, dersom de vektlegger å finne et leirsted med universell utforming, og for konfirmantene, som ofte må reise et stykke og være i fremmede og svært sosiale omgivelser over flere dager.

Siden trosopplæringsplanen ble tatt i bruk, har det skjedd politiske og juridiske endringer innen likestilling og diskriminering (Likestillings- og diskrimineringsloven, 2018). Likestillings- og diskrimineringsloven fra 2018 trådte i kraft i 2009 under navnet diskriminerings- og tilgjengelighetsloven og er inkludert i planen (Kirkerådet, 2010, s. 29). FNs konvensjon om rettighetene til personer med nedsatt funksjonsevne ble signert i 2007 og ratifisert av Norge i 2013 (Barne- og likestillingsdepartementet, 2013). Kirkenes Verdensråd har vedtatt to dokumenter om inkludering og likeverd. Disse er A Church of All and for All (Kirkenes Verdensråd, 2004) og The Gift of Being / Tilvorelsens gave (Kirkenes verdensråd, 2016 / Norges Kristne Råd [NKR], 2017). Ingen av disse internasjonale politiske og teologiske dokumentene er nevnt i planen for trosopplæring. Planen er tydelig på at universell utforming er kirkens generelle ansvar. Imidlertid følges ikke dette opp med en konkretisering av hvordan ansvaret skal tolkes. Betyr det for eksempel at menigheten ikke skal bruke arenaer som har dårlig tilgjengelighet? 
Det presiseres i planen for trosopplæring at menigheten skal innhente kunnskap om barn og unge i lokalmiljøet med behov for individuell tilrettelegging (Kirkerådet, 2010, s. 29). Imidlertid fremhever ikke planen at menighetene bør kartlegge de fysiske rommene som brukes i trosopplæringen for eksempel kirkebygg, klubblokaler og leirsteder, med henblikk på universell utforming. Sett i lys av en relasjonell forståelse av funksjonshemming, hvor funksjonshemming oppstår i menneskers interaksjon med de sosiomaterielle omgivelsene, blir registrering av barns og unges behov for tilrettelegging feil. Når trosopplæringsplanen oppfordrer menighetene til å samle inn kunnskap om barn og unge med behov for tilrettelegging, uttrykker planen en medisinsk og individualisert forståelse av funksjonshemming. Det kan også være juridisk problematisk og i strid med personvernet å oppfordre menigheter til å samle inn kunnskap om enkeltpersoner i lokalmiljøet.

\section{Kan alle delta i kirkens tilbud om konfirmasjon?}

I dette avsnittet presenterer jeg funn fra intervju- og dokumentstudiene. Fordi konfirmasjonen er det største breddetiltaket i trosopplæringen, var jeg interessert i å undersøke hvordan inkludering og tilrettelegging ble ivaretatt her. Flere deltar i konfirmasjonsundervisningen enn i andre av trosopplæringens aktiviteter, og derfor vil unge som ellers ikke har hatt et forhold til kirken, komme til kirken for å få trosopplæring og bli konfirmert.

Alle barn og unge skal ha et reelt tilbud om trosopplæring (Kirkerådet, 2010, s. 28). Dette er å forstå som en forpliktelse for kirken som er forankret i likestillings- og diskrimineringsloven (likestillings- og diskrimineringsloven, 2018; Engedal, Fagermoen \& Sandsmark, 2015, s. 6). Frem til 1912 var det tvungen konfirmasjon i Norge (Lid, 2018). Fremdeles er det vanlig blant lutherske kristne ungdommer i Norge å gjennomføre konfirmasjonen, og dette forbindes med en form for normalitet (Engerdal et al., 2015). Unge deltar i konfirmasjonsopplegget sammen med sine jevnaldrende, og 57, 9 prosent av femtenåringene ble konfirmert i 2017 (Statistisk Sentralbyrå, 2017). 
Som vi har sett, er det satt av 60 timer til konfirmasjonstiden i planen for trosopplæring. Disse timene skal brukes til opplæring og sosiale aktiviteter. Hvis konfirmanten ikke tidligere har vært engasjert i trosopplæringen, gir de 60 timene svært liten tid til å bli kjent med konfirmanten og få innsikt i vedkommendes behov for tilrettelegging. Ikke minst gjelder dette med tanke på den tilliten som er nødvendig å etablere mellom konfirmanten, dennes familie og kirkens ansatte (Lid, 2015). Menighetene har et relativt likt opplegg for konfirmasjon, som omfatter undervisning, aktiviteter i kirkerommet og leir. Ordet «aktivitet» omfatter både mer kontemplative aktiviteter, som bønn og meditasjon, og aktive aktiviteter som for eksempel lek og konkurranse på leir. Jeg kommer her ikke til å gå spesifikt inn på deler av opplegget, bortsett fra der det er direkte relevant for kapitlets tematikk.

Menighetene gikk bredt ut og inviterte ungdommene i soknene til å bli konfirmert. Det var imidlertid mindre kunnskap og bevissthet om hva som kreves for at alle skulle kunne delta i konfirmantopplegget. Dette gjaldt både romlige og bygningsmessige forhold og personlig oppfølging i form av støttekontakt og behov for individuell assistanse. De ansatte i menighetene ga uttrykk for en avklart forståelse av at noen hadde ansvar for inkludering og tilrettelegging i trosopplæringen og i konfirmasjonsopplegget, men det kunne være mindre klart hvor omfattende dette ansvaret var. Det var for eksempel ikke tydelig hvor ansvaret lå for at arenaer som ble brukt til aktiviteter, var universelt utformet. Det var også uklart om det var menighetens eller konfirmantens ansvar å sørge for oppfølging på aktivitetene i de tilfellene der dette var nødvendig.

Fordi konfirmantopplegget ikke varer lenger enn et knapt år, er det ofte ikke nok tid til å avklare behov på forhånd. Dermed hender det at konfirmant og menighet får overraskelser underveis fordi den individuelle og universelle tilretteleggingen ikke er god nok. Menigheten på sin side er ofte inviterende og understreker at alle er velkomne til å delta i konfirmantopplegget, men kanskje uten å vite sikkert at opplegget det inviteres inn til, er kvalitetssikret med tanke på universell utforming og individuell tilrettelegging.

For eksempel var det uavklart hvem som skulle dekke utgifter til støttekontakt der dette var nødvendig for deltakelse. Kommunene mente, 
ifølge intervjupersoner, at menigheten måtte dekke utgifter til støttekontakt, mens menigheten anså dette for å være et kommunalt ansvar. For den enkelte konfirmant blir det uforutsigbart og vanskelig dersom en relativt kortvarig aktivitet som konfirmasjonsopplæringen skal begrense muligheten til å delta på andre aktiviteter, som for eksempel idrett. Dette vil være konsekvensen dersom tildelte støttekontakttimer skal gå til konfirmasjonsopplæring. Et mulig løsning kunne være å øke timer til støttekontakt i konfirmasjonstiden.

Ifølge Verdens helseorganisasjon lever omkring 15 prosent av befolkningen med funksjonsnedsettelse (WHO og Verdensbanken, 2011). Derfor vil det i de fleste konfirmantkull være konfirmanter med kognitiv, fysisk, psykisk, sensorisk eller sosial funksjonsnedsettelse. Noen av konfirmantene vil kunne ha behov for generell eller individuell tilrettelegging for å kunne delta i konfirmasjonsopplegget. Et eksempel på generell tilrettelegging er at man ivaretar at byggene som brukes til konfirmantopplæringens aktiviteter, så som kirkerom og leirsted, er universelt utformet. Det betyr at det må være toalettfasiliteter tilgjengelig for rullestolbrukere, og at de lett kan komme seg til og fra og bruke hele bygningene som brukes til leir. Alle menighetene i mitt materiale hadde opplevd problemer på disse områdene, uten at det var gjort noen strategiske valg for å sikre at universell utforming ble tatt med i vurderingen da leirsteder ble valgt.

Det var stor variasjon mellom kirkebyggene til de fire menighetene. Noen var relativt nye eller nyrenovert og hadde prioritert universell utforming, mens andre kirkebygg hadde svært dårlig tilgjengelighet. Det var overraskende å se at flere år etter at CRPD ble ratifisert og likestillings- og diskrimineringsloven trådte i kraft, var det likevel forholdsvis lite oppmerksomhet på disse temaene. Det var akseptert at leirstedene som ble brukt, ikke var universelt utformet.

Ingen av intervjupersonene uttrykte uenighet med målsettingen om inkludering og tilrettelegging for deltakelse. Flere hadde imidlertid erfaring med ikke å få dette til i praksis. Når man ikke lykkes helt med å skape inkludering og tilrettelegging, erfares dette som en form for konflikt mellom ideal og virkelighet. De fleste jeg intervjuet, hadde erfaring med prosesser hvor man ikke hadde lyktes. Men det var også flere som 
hadde opplevd å få til gode mellomløsninger. Dette kunne for eksempel være en kombinasjon av individuell og universell tilrettelegging hvor en konfirmant deltok på deler av opplegget, men ikke på alt.

Jeg har fortolket intervjupersonene i lys av det menigheten ønsket å oppnå, og jeg har forsøkt å forstå hva de har erfart som inkludering og hva som hindret inkludering og tilrettelegging. Jeg vil i det følgende presentere tre temaer som trådte fram som viktige. Disse er forståelsesmodeller for funksjonshemming, betydningen av strukturelle og organisatoriske forhold og inkludering som sosiomateriell praksis.

\section{Medisinske forståelsesmodeller har forrang}

De ansatte i menighetene beskrev i hovedsak en forståelse av funksjonshemming som var i tråd med medisinske modeller, og brukte medisinske ord og begreper. Unntaket var ansatte i Døvekirken, som primært forholdt seg til døve og hørselshemmede. Enkelte var opptatt av bruk av og muligheten til å kunne administrere medisiner, mens andre var opptatt av problemer knyttet til samhandling med andre aktører, for eksempel offentlig forvaltning.

Flere utrykte en følelse av maktesløshet fordi det var vanskelig å vite hvordan man best mulig, innenfor gitte rammer og ressurser, faktisk hadde mulighet til å legge til rette for likeverdig deltakelse. Dette handlet også om at de hadde kort tid til å bli kjent og bygge tillit. Både konfirmanter med funksjonsnedsettelse og deres foreldre har kanskje også gjort seg dårlige erfaringer i andre sammenhenger, noe som får betydning for deres åpenhet og tillit i møte med kirken.

Et eksempel på at medisinske forståelser av funksjonshemming har forrang, er at menighetene oppfordres til å innhente informasjon om barn og unge i nærmiljøet som har behov for tilrettelegging. Når trosopplæringsplanen oppfordrer menighetene til en slik registrering, indikerer det at det er personens medisinske og helsemessige tilstand som er viktigst å ha informasjon om for å kunne praktisere en inkluderende trosopplæring. En slik informasjonsinnhenting er imidlertid mindre nødvendig dersom man tar som utgangspunkt at det alltid er personer med ulike former for funksjonsnedsettelser blant menighetens barn og unge 
og deres familier og venner. På en slik bakgrunn - og med utgangspunkt i offisielle juridiske og politiske forståelser av funksjonshemming som noe som oppstår i en relasjon mellom mennesker og deres omgivelser - kan menighetene nøye seg med å be konfirmanter, foreldre og foresatte om å ta kontakt dersom det er behov for individuell tilrettelegging ut over universell utforming.

Norsk politikk og offentlighet har siden tidlig på 200o-tallet vært preget av det som kalles relasjonelle forståelser av funksjonshemming. Funksjonshemming oppstår da som resultat av et komplekst samspill mellom mennesket og de sosiale, kulturelle og materielle omgivelsene (Lid, 2020). Slike relasjonelle forståelser fant jeg få spor av i materialet. Det var også i mindre grad laget systematiske oversikter over tilgjengelighet og barrierer i de rom og bygg som menighetene brukte til konfirmasjonsopplegget og til trosopplæring generelt. Det virker som om dette området ikke er høyt prioritert.

Medisinsk forståelse av funksjonshemming innebærer en individualisering på bekostning av samfunnsperspektivet. Det er riktig at funksjonsnedsettelse kan henge sammen med personens helsetilstand. Men for å kunne redusere barrierer som skaper funksjonshemming i konkrete situasjoner, er det nødvendig å ha kunnskap om mangfoldet blant personers funksjonsevner, både generelt og konkret. Menighetene bør også i større grad prioritere å etablere systematisk kunnskap om tilgjengelighet og universell utforming i de byggene som brukes, og om det pedagogiske opplegget. Da er det mulig å gi konfirmanter og deres foresatte en presis beskrivelse av tilbudet og dermed blir det også lettere for konfirmanter og foresatte å vurdere hvorvidt det er mulig å delta i det opplegget menigheten tilbyr.

\section{Strukturelle og organisatoriske forhold}

Hvem som inkluderes i trosopplæringen, sier noe om hvem som hører til. Både kjønn og seksuell orientering er temaer som har fått gjennomslag som allment viktige temaer i trosopplæringen. Funksjonsevne og funksjonsnedsettelse ser ut til å være regnet som noe mer marginalt. Alle har funksjonsevne, og det er svært mange ulike måter å ha nedsatt 
funksjonsevne på. I CRPD artikkel 1 konkretiseres kognitiv, fysisk, sensorisk og mental funksjonsevne. Menighetene så på inkludering som sitt ansvar, men flere pekte på at de ønsket et bedre samarbeid med kommunen. Dette kunne være om både økonomiske og pedagogiske forhold.

I trosopplæringsplanen gis det en struktur og organisering av opplegget (Kirkerådet, 2010). Hver enkelt menighet organiserer sitt opplegg med utgangspunkt i de føringene på tidsbruk og innhold som ligger i planen. Det innebærer samarbeid internt i staben og med frivillige om å gjennomføre opplegget og eksternt med konfirmanten og hans eller hennes foreldre eller foresatte. Tidsrammen er anslått til 60 timer, og søkelyset er rettet mot troens innhold, praksis- og fellesskapsdimensjoner i dialog med konfirmantens livsspørsmål. Konfirmantens livsspørsmål kan handle om temaer som er av eksistensiell betydning. Erfaringer med funksjonsnedsettelse og funksjonshemming på egne vegne eller blant familie og venner hører inn under slike livsspørsmål som er av betydning for konfirmanter. Slike temaer er imidlertid sårbare og kan være vanskelige å komme inn på hvis man ikke kjenner hverandre fra før.

Trosopplæringen er preget av et læringssyn som vektlegger barns og unges aktørskap (Reite, 2015, s. 26). Planen verdsetter ungdoms medvirkning i den grad at «[a]lle aktiviteter som er rettet mot ungdom, bør involvere ungdom i planleggingen» (Kirkerådet, 2010, s. 22). Ungdommene jeg fikk intervjue, opplevde at de i liten grad hadde innflytelse på konfirmantopplegget, og på spørsmålet svarte de «ingenting» (intervju 4, 2016).

Samarbeid er viktig både internt blant menighetens ansatte og med konfirmanten og dennes foreldre eller foresatte. Et aspekt ved samarbeidet er kunnskap om hvilke velferdsstatlige ordninger som finnes, for eksempel finansiell støtte til å sikre universell utforming i bygg og uteområder samt til støttekontakt. Flere menigheter pekte på at det var en risiko for å love for mye i møtet med konfirmanten og dennes foreldre eller foresatte. Menigheten går ut og sier at alle skal være velkomne, og så viser det seg konkret at det ikke er økonomiske eller menneskelige ressurser til å gi konfirmantene god nok oppfølging gjennom konfirmantopplegget, og det er uklart hvem som har ansvar for å dekke de utgiftene som kan komme til å oppstå, for eksempel i tilknytning til personressurser. 
Ingen av menighetene fortalte om samarbeid med kommunene om dette. Dette er kanskje heller ikke naturlig på et mikronivå knyttet til enkeltpersoner, men på et system- og organisatorisk nivå ville kanskje et samarbeid med kommunene om ressurser kunne være nyttig.

\section{Inkludering og medborgerskap som praksis}

Konfirmantopplæring og konfirmasjon foregår på steder som sjelden er bygd for formålet. Tilgjengeligheten til kirkebygg og leirsteder er i liten grad kartlagt. Dette kan utgjøre barrierer som hindrer deltakelse for konfirmanter, ledere og familiemedlemmer. Leirstedene ligger ofte usentralt til, er bygd før ny plan- og bygningslov trådte i kraft i 2010 og ofte av ideelle aktører med begrensede midler. Konfirmantene og lederne forventes å kunne delta på leir i flere dager. Konfirmantleiren er en del av det pedagogiske og sosiale opplegget. Konfirmanter som hindres fra å delta på leir, går dermed glipp av en viktig del av konfirmasjonstiden. Flere av konfirmantene trakk frem samholdet på leiren som viktig. Dette betyr at når konfirmantene møtes igjen etter leiren, vil de som ikke har vært med på leir, til en viss grad også stå utenfor fellesskapet.

Menighetene hadde begrenset kunnskap om hvordan funksjonshemming oppstår i konkrete situasjoner. Det var også mindre kunnskap om hvilke behov personer med fysiske, psykiske, kognitive og sosiale funksjonsnedsettelser har for å kunne delta i konfirmasjonsopplegget. Flere hadde bibelutgaver tilpasset bruk av konfirmanter med kognitiv funksjonsnedsettelse, men færre hadde innsikt i kompleksiteten i personomgivelse interaksjonen. Dermed var sjelden de beste forutsetningene til stede for å kunne ivareta likeverdige muligheter for deltakelse. Flere menigheter erkjente at de stedene som ble brukt, ikke hadde god tilgjengelighet eller universell utforming.

En del hadde erfaringer med individuell tilrettelegging, gjerne i form av individuelle opplegg for enkeltkonfirmanter. Noen nevnte også et ønske om å kunne samle konfirmanter med funksjonsnedsettelse i egne grupper. Men, hvis for eksempel menighetene i en by samarbeidet om et opplegg for konfirmanter med Downs syndrom, ville dette være en segregerende praksis og ikke inkludering. Ideologien som ligger til grunn 
for inkludering og medborgerskap, er at mangfoldet blant oss mennesker verdsettes og skal ha rom. Vi lærer og erfarer verden sammen. Hvis barn og unge erfarer at de som er sammen på skolen, ikke kan være en del av samme fellesskap i konfirmantopplæringen, har kirken, som en åpen og inkluderende folkekirke, et problem.

\section{Etiske dimensjoner ved inkludering og tilrettelegging}

Både konfirmasjonsopplegget og trosopplæringsplanen gir lite rom for fleksibilitet. Aktivitetene som forventes gjennomført, beskrives på konkrete måter, og den som ikke kan delta på aktivitetene, tilbys gjerne et individuelt tilrettelagt opplegg segregert fra resten av konfirmantgruppen.

Når en menighet velger å bruke steder og rom og gjennomføre aktiviteter som ikke er tilgjengelige for konfirmanter med funksjonsnedsettelse, signaliserer man at denne formen for diskriminering ikke er så alvorlig. Konfirmantene i studien tok det for gitt at alle ikke kunne delta på alt, og at det for eksempel var vanskelig for en konfirmant med funksjonsnedsettelse å delta på konfirmantleir. Denne etiske dimensjonen ved tilgjengelighet og utilgjengelighet er viktig å være klar over, fordi konfirmantene som er deltakere i konfirmantundervisningen, til daglig lever i et samfunn og går på en skole som vektlegger inkludering og medbestemmelse.

Variasjoner i funksjonsevne handler om kroppslig sårbarhet. Kirken har på helt grunnleggende vis et forhold til menneskers sårbarhet, først ved at den møter mennesker i sårbare livssituasjoner som fødsel, død og kjærlighet, og dernest gjennom gudsrelasjonen, Gud som skaper, som menneske og som fellesskap. Menighetspraksis rommer rike kilder til refleksjon over sårbarhet og til å praktisere fellesskap som gir rom for sårbarhet. Trosopplæringen er ikke en isolert del av menighetens praksis, men inngår i menighetens arbeid og kan bidra til utvikling i menigheten (Leganger-Krogstad, 2017; Birkedal \& Austnaberg, 2017). I trosopplæringen og konfirmasjonen er det et ubrukt potensial for å utvikle det som gjerne kalles anerkjennende forståelser av variasjoner i funksjonsevne. I Bibelens tekster og i kirkens historie finnes det kildemateriale som 
utfordrer samtidens medisinske fortolkninger av funksjonsevnevariasjoner (Solevåg, 2018; Reynolds, 2008). Slike ressurser brukes i liten grad eksplisitt i trosopplæringen.

Konfirmasjonens teologiske betydning ligger blant annet $\mathrm{i}$ at unge mennesker, ved å delta i konfirmasjonsopplegget og la seg konfirmere i kirken de er døpt i, får en erfaring av hva det kan bety å være skapt i Guds bilde. Nettopp av denne grunn er det viktig at alle skal kunne ta del i trosopplæring og konfirmasjon, noe også menighetene la vekt på. Samtidig har konfirmantopplegget en avgrenset tidsramme - det varer i mindre enn ett år. For en person som ikke har deltatt i trosopplæringen tidligere, er dette kort tid å bli kjent og trygg nok til å dele sin erfaring med funksjonshemming for å få universell eller individuell tilrettelegging. Denne tilliten må bygges opp og forvaltes over en kort periode. Det kan se ut til at dette kan være vanskelig for både ansatte og konfirmanten og dennes familie.

Det var i varierende grad kunnskap om tilgjengelighet og tilrettelegging i menighetene. En av menighetene skilte seg ut ved at den hadde et nyere kirkebygg med god universell utforming, men denne menigheten brukte i stor grad også andre arenaer for samlinger.

Den amerikanske filosofen Martha Nussbaum hevder at det er nødvendig å ta utgangspunkt $\mathrm{i}$ et menneskesyn som rommer forståelser av mennesker som kroppslig sårbare og med ulike funksjonsevner. På dette grunnlaget må man da også ta utgangspunkt i at kognitive, fysiske og sosiale funksjonsevner varierer. Det å forvente et mangfold innen funksjonsevner blir da en normalitet som bør prege institusjonenes praksis, for eksempel kirkens trosopplæring, tydeligere.

Når inkludering og tilrettelegging er sentrale dimensjoner i trosopplæringsplanen, kunne man kanskje forvente at arenaer som ikke har god tilgjengelighet, for eksempel for hørselshemmede, bevegelseshemmede eller synshemmede, ikke ville bli brukt. Slik er det ikke, og det er grunn til å undre seg over at menighetene ikke ser ut til å ha endret praksis på dette området, til tross for endringer i politikk og lovgivning.

Tilgjengelighet handler om de sosiomaterielle omgivelsene (GarlandThomson, 2016). For trosopplæringen betyr dette at både de fysiske forholdene som er knyttet til stedene som brukes - og deres materielle og 
tekniske tilgjengelighet - og det sosiale samspillet mellom konfirmanter og ansatte eller frivillige samt det teologiske innholdet er viktig. Som vi har sett, er det ifølge Plan for trosopploering forventet at unge deltar i planlegging og gjennomføring av aktiviteter som de skal delta i (Kirkerådet, 2010, s. 22). I denne studiens materiale var det relativt liten grad av involvering av unge i konfirmantopplegget. Her er det imidlertid også et potensial for å styrke inkluderingen ved at konfirmantene deltar i planlegging. Det kan tenkes at konfirmantene selv ville ha unngått å bruke arenaer som ville være utilgjengelige for noen av dem.

Som det er nå, signaliseres det til konfirmantene at diskriminering på grunnlag av funksjonsevne kanskje ikke er så alvorlig. Dermed minskes muligheten for å praktisere mestring i åpne og inkluderende fellesskap samt for å vise kirken som en åpen og inkluderende folkekirke forankret i folket som et mangfoldig fellesskap.

Ved å involvere konfirmanter i planlegging og gjennomføring av konfirmantopplegget er det også muligheter for sammen å utvikle og bruke et språk som fremmer deltakelse (Gustavsson, 2004). En faktor som kan vanskeliggjøre dette, er igjen tidsfaktoren. Her er det imidlertid også gode muligheter for å tenke integrerende med utgangspunkt i læring gjennom deltakelse (Reite, 2015). Da er det mulig å se på samhandling med konfirmantene som en del av det totale konfirmantopplegget, noe som kan styrke konfirmantenes mulighet for å kunne påvirke opplegget.

\section{Oppsummering}

Trosopplæringen slik den organiseres av kirkens trosopplæringsplan, har mange og krevende aktiviteter. De forventes for eksempel at alle elleveåringer skal opp i kirketårnet, og at alle niåringer skal overnatte i kirken. Denne konkrete måten å forstå aktivitet på ekskluderer elleveåringer som ikke klatrer opp i et tårn, og niåringer som ikke ønsker å overnatte i kirken.

Studien som her er presentert, indikerer at det kan være behov for revisjon av trosopplæringsplanen i lys av inkludering og tilrettelegging, som er blant planens sentrale dimensjoner. Inkludering og tilrettelegging krever større grad av åpenhet i møte med mangfoldet av barn og unge 
og deres familier. Menighetenes kunnskap om inkludering og tilrettelegging bør styrkes, og det gjelder også menighetenes kunnskap om barrierer i bygningsmassen som brukes i trosopplæringen.

Den forståelsen av tilgjengelighet og funksjonshemming som preger planen, ser ut til å være tettere på medisinske forståelsesmodeller enn sosialrelasjonelle. På bakgrunn av en analyse av funksjonshemming som relasjonell, har jeg etterlyst en kartlegging av arenaer som brukes til trosopplæringens aktiviteter, og en tydeligere verdibevisst holdning til ikke å legge aktiviteter til arenaer som er utilgjengelige for konfirmanter med funksjonsnedsettelse. En slik tydelig holdning fra menighetenes side ville kunne legge opp til at konfirmantene får erfaringer av deltakelse og mestring i fellesskap som preges av at alle barn og unge er forskjellige, også når det gjelder funksjonsevner.

Det er behov for mer forskning på hvordan trosopplæringsplanen gir rom for deltakelse og inkludering i praksis. Kanskje er det slik at bruken av begrepet «tilrettelegging» fører til at man for raskt legger opp til et individuelt tilrettelagt opplegg for barn og unge med funksjonsnedsettelser, i stedet for å arbeide for å få til bedre universelle løsninger. I tillegg er det nødvendig å evaluere trosopplæringens innhold i et sårbarhets- og funksjonshemmingsperspektiv.

\section{Referanser}

Barne-, likestillings- og inkluderingsdepartementet. (2013). Konvensjon om rettighetene til mennesker med nedsatt funksjonsevne (CRPD). Oslo: Barne-, likestillings- og inkluderingsdepartementet.

Birkedal, E. \& Austnaberg, H. (2017). Planarbeid i trosopplæring som ressurs for menigheten? Prismet, 68(3), 189-209.

Bogner, A., Littig, B. \& Menz, W. (2009). Interviewing experts. Basingstoke, England: Palgrave Macmillan.

Botvar, P. K., Haakedal, E. \& Kinserdal, F. (2013). Når porten gjøres vid: evaluering av trosopploringens breddetiltak (Vol. 2013:2). Oslo: KIFO Stiftelsen kirkeforskning.

Butler, J. (2015). Notes toward a performative theory of assembly. Cambridge, MA: Harvard University Press.

Casey, E. S. (1997). The fate of place: A philosophical history. Berkeley, CA: University of California Press. 
Engedal, L. G., Fagermoen, T. \& Sandsmark, A. (2015). Trosopploering for alle? Laring, tro og sårbare unge (s. 6-12). Oslo: IKO-Forlaget.

Garland-Thomson, R. (2016). Misfits: A feminist materialist disability concept. I P. Devlieger, B. Miranda-Galarza, S. E. Brown \& M. Strickfaden (Red.), Rethinking disability: World perspectives in culture and society (s. 165-179). Antwerpen: Garant Publishers

Grue, J. (2018). Jeg lever et liv som ligner deres: en levnetsbeskrivelse. Oslo: Gyldendal Gustavsson, A. (2004). Delaktighetens språk. Lund: Studentlitteratur.

Kirkerådet. (2010). Plan for trosopplaring. Gud gir - vi deler. Oslo: Den norske kirke. Kvale, S. (2007). Det kvalitative forskningsintervju (10. utg., red.). Oslo: Gyldendal Akademisk.

Lid, I. M. (2020). Universell utforming og samfunnsdeltakelse. Oslo: Cappelen Damm akademisk.

Lid, I. M. (2018). Opplæring og omsorg. I Diakoni og velferdsstat: Utvikling av en diakonal praksis i samspill med myndigheter, sivilsamfunn og borgere (s. 15-36). Oslo: Gyldendal Akademisk.

Lid, I. M. (2015). Sårbarhet og verdighet. I S. Dahle \& T. I. Torgauten (Red.), Helt med! I samme fellesskap uavhengig av funksjonsevne (s. 66-77). Oslo: Gyldendal Akademisk.

Lid, I. M. (2012). Variasjoner i funksjonsevne som vilkår: En diskusjon av funksjonshemming og menneskesyn i lys av Martha Nussbaums politiske filosofi. Norsk Filosofisk Tidsskrift, (2), 130-145.

Leganger-Krogstad, H. (2017). Trosopplæring og gudstjenester. Menighetsutvikling i dybde og bredde. Prismet, 68(3), 243-258.

Likestillings- og diskrimineringsloven. (2018). Lov om likestilling og forbud mot diskriminering. (LOV-2017-06-16-51). Hentet fra https://lovdata.no/dokument/ NL/lov/2017-06-16-51

Lund, I. (2011). Sårbare elever i skolen: Ulike perspektiver og tilrettelegging av læringsmiljøet. Spesialpedagogikk, 76(2), 13-21.

Nussbaum, M. C. (2004). Hiding from humanity: Disgust, shame, and the law. Princeton, NJ: Princeton University Press.

Nussbaum, M. C. (2007). Frontiers of justice: Disability, nationality, species membership. Cambridge, MA: Belknap Press of Harvard University Press.

Reite, I. (2015). Tilrettelagt trosopplæring? I L. G. Engedal, T. Fagermoen \& A. Sandsmark (Red.), Trosopploring for alle? Loering, tro og sårbare unge (s. 13-30). Oslo: IKO-Forlaget.

Reynolds, T. E. (2008). Vulnerable communion. A theology of disability and hospitality. Grand Rapids, Michigan: Brazos Press.

Solevåg, A. R. (2018). Negotiating the disabled body: Representations of disability in early Christian texts (Vol. no. 23). Atlanta, GA: SBL Press. 
Statistisk sentralbyrå (SSB). (2017). Den norske kirke - hovedtall. Hentet 15.04.2020 fra https://www.ssb.no/kirke_kostra

Thomson, R. G. (1997). Extraordinary bodies: Figuring physical disability in American culture and literature. New York: Columbia University Press.

Tjora, A. H. (2017). Kvalitative forskningsmetoder i praksis (3. utg., red.). Oslo: Gyldendal Akademisk.

World Council of Churches. (2003). A church of all and for all: An interim statement. Genève: World Council of Churches.

World Council of Churches. (2015, 16.-20. mars). The gift of being: Called to be a church of all and for all. Genève: Bossey Ecumenical Institute.

World Health Organisation. (2011). World report on disability. Geneva: World Health Organization.

\section{Intervjumateriale}

Intervju 4, 13.09.2016: Gruppeintervju med konfirmanter.

\section{Nettsider}

Kirkemøtet (2011). https://kirken.no/nb-NO/om-kirken/slik-styres-kirken/ kirkemotet/dokumenter_vedtak/kirkemotet-05.04.2011---10.04.2011-tonsberg/ Lastet ned 2. juni 2020. 


\title{
KAPITTEL 3
}

\section{Når det å være til er nok: Et profesjonsetisk blikk på menneskeverd og sårbarhet}

\author{
Anita Gjermestad \\ VID vitenskapelige høgskole
}

\begin{abstract}
Questions regarding dignity and moral worth of children and adults with profound intellectual disability are hugely contested and discussed. An implicit dimension in these discussions is whether a life with disability is worth as much as a life without. Healthcare and social care workers need to reflect upon fundamental values, which can inform good care practises, enhance dignity, and secure the welfare of all citizens. In this chapter, the theological text Gift of Being is used as a stepping stone together with relevant theoretical perspectives related to care, philosophy agency and rationality to shed light on professional ethics and care practices with persons with profound intellectual disability. A language of care that emphasizes relational understandings of disability, common human vulnerability and human diversity regarding persons with profound intellectual disability is advocated. Furthermore, the language of care needs to bring forward understandings of agency and citizenship as embodied phenomena rather than rational ones.
\end{abstract}

Keywords: profound intellectual disability, vulnerability, agency, citizenship, professional ethics

\section{Innledning}

Som helse- og sosialarbeider og forsker innen funksjonshemmingsfeltet har jeg erfaring fra både omsorgsarbeid og forskning sammen med barn,

Sitering av denne artikkelen: Gjermestad, A. (2020). Når det å være til er nok: Et profesjonsetisk blikk på menneskeverd og sårbarhet. I I. M. Lid \& A. R. Solevåg (Red.), Religiøst medborgerskap: Funksjonshemming, likeverd og menneskesyn (Kap. 3, s. 69-88). Oslo: Cappelen Damm Akademisk. https://doi. org/10.23865/noasp.10o.ch3

Lisens: CC BY-NC-ND 4.o. 
unge og voksne personer med alvorlig utviklingshemming. ${ }^{1}$ I lys av dette har jeg vært særlig opptatt av menneskeverd og livsvilkår, og av hvordan den profesjonelle forstår og møter barn, unge og voksne med alvorlig utviklingshemming. Som profesjonell omsorgsutøver er egne forestillinger og egen forståelse av den som skal motta hjelp, avgjørende for kvaliteten på hjelpen man yter (Rogers, 2017). Slike forestillinger handler dypest sett om hvilke kunnskaper og ferdigheter den profesjonelle omsorgsutøverens besitter, i tillegg til hvilke grunnleggende verdier og holdninger som preger hennes handlinger og væremåter i møte med dem som mottar hjelp. Som profesjonell aktør er bevissthet på egne verdier og holdninger i møte med barn, unge og voksne med alvorlig utviklingshemming av stor betydning, da denne gruppen borgere er særlig utsatt for devaluerende og krenkende holdninger (Mansell, 2010; Vorhaus, 2016).

Det er nettopp de alvorlig nedsatte kognitive og kommunikative funksjonene, som kjennetegner personer med alvorlig utviklingshemming, som brukes til å stille spørsmål ved deres menneskeverd, rett til liv og status som moralske subjekter (Curtis \& Vehmas, 2014; Singer, 2010). Slike verdimessige spørsmål knyttet til menneskeverd har vært gjenstand for diskusjon i ulike fagtradisjoner (Curtis \& Vehmas, 2014; Kittay \& Carlson, 2010). En underliggende dimensjon i disse diskusjonene knytter an til generelle spørsmål om hvorvidt et liv med funksjonsnedsettelse anerkjennes som like mye verdt som et liv uten (Hanisch, 2014). Videre brukes særlig deres nedsatte kognitive funksjoner, evne til rasjonell tenking og resonnering som argument for å stille spørsmål ved deres aktørskap, subjektivitet og rett til selvbestemmelse (Singer, 2010; Watson, 2016). Kirken har til dels også bidratt til å så tvil om menneskeverdet til personer med utviklingshemming. Særlig danner helbredelsesfortellingene i Det nye testamente grobunn for oppfatninger av at funksjonshemming og sykdom kan være resultat av synd, straff eller manglende tro (Norges Kristne Råd [NKR], 2017, s. 7, 20). Samtidig har kirken også vært

1 I kapitlet brukes begrepet «alvorlig utviklingshemming». Det understrekes at alvorlig utviklingshemming i denne sammenheng omfatter både alvorlig og dyp utviklingshemming slik det beskrives i ICD-10 (WHO, 2010). Kontinuerlig bistandsbehov og alvorlig nedsatte kognitive og kommunikative funksjoner kjennetegner denne gruppen, i tillegg til at IQ beskrives å være under 34 (ICD-10). 
forkjemper for menneskeverdet til alle mennesker. Ecumenical Disability Advocates Network (EDAN) og teksten Tilvoerelsens gave (Norges Kristne Råd [NKR], 2017) har særlig bidratt til et paradigmeskifte i kirkens tradisjonelle forstålse av personer med funksjonsnedsettelse generelt og utviklingshemming spesielt.

Profesjonsetikk handler om den profesjonelles ansvar for å realisere «den andres» velferd og beste (Botnen Eide, 2018; Aadland, 2018). Men hva som er den andres beste er ikke gitt, og svaret på dette er uløselig knyttet sammen med møtet med den andre, situasjon, kontekst og den profesjonelles kunnskaper og verdier (Botnen Eide, 2018; Aadland, 2018). Flere tar til orde for at det også er behov for et språk for gode omsorgspraksiser, slik at velferden til dem det gjelder, sikres (Aadland, 2018; Aakre, 2016). Verdimessige, etiske og moralske valg foregår ofte uartikulert og språkløst og inngår som en taus dimensjon ved den profesjonelles handlinger (Aakre, 2016). I praksis betyr dette at et profesjonsetisk språk alltid er under utvikling i lys av profesjonens eget fagspråk og kultur for å gi retning til idealer og gode praksiser (Aadland, 2018). Et profesjonsetisk språk er ikke gitt, men er noe som vokser frem i takt med språkliggjøring av profesjonenes mandat og verdier.

Hensikten med dette kapitlet er å bidra til profesjonsetisk bevissthet og gi innhold til et språk rettet mot omsorgspraksiser sammen med barn, unge og voksne med alvorlig utviklingshemming - et språk som bidrar til å synliggjøre menneskeverdet og aktørskapet til denne gruppen, og som gir grunnlag for utvikling av moralske og respektfulle omsorgspraksiser. I kapitlet er et slikt profesjonsetisk perspektiv og språk særlig inspirert av den teologiske teksten Tilvarelsens gave (NKR, 2017). Til tross for at profesjonsetikken skal være livssynsnøytral, berører den teologiske teksten Tilvorelsens gave sentrale verdier som er verdifulle faglige og etiske ledestjerner i det profesjonelle omsorgsarbeidet med denne gruppen mennesker, og som kan åpne for nye nyanser i vår forståelse av menneskesyn og medborgerskap knyttet til alvorlig utviklingshemming.

Selv om hele teksten åpner for verdifulle profesjonsetiske refleksjoner, har jeg valgt ut tre berøringspunkter i Tilvorelsens gave (NKR, 2017) som beriker og kan gi klangbunn til et profesjonsetisk språk og en forståelse av omsorgspraksiser sammen med barn og unge med alvorlig 
utviklingshemming. Det første berøringspunktet (a) er verdsetting av menneskelig mangfold. Teksten peker på en feiring av menneskelig mangfold og variasjoner i kropp og funksjon, talenter og begrensninger for alle, samt en bevissthet på at alle mennesker lever med begrensinger av forskjellig slag (s. 8-9). Det andre punktet (b) er livets verdi. Alle mennesker har lik verdi for Gud. Alle liv har verdi - fordi vi lever og er til, selv om alle mennesker er forskjellige og har hver sin unike egenart (s. 9-10). Som mennesker er vi alle gaver til hverandre med tilknytning og relasjon til andre, uavhengig av funksjonsnedsettelse. Det tredje og siste punktet (c) er menneskelig sårbarhet, at alle er mennesker er sårbare i seg selv. Sårbarhet er en del av den menneskelige tilstanden og knyttes ikke til funksjonsnedsettelse. Alle erfarer skrøpelighet og begrensinger (s. 18). Det skapes ofte et falskt inntrykk av at personer uten funksjonsnedsettelse er sterke og klarer seg selv. De fleste erfarer nedsatte funksjoner i ulik grad igjennom livet (s. 18-19).

I lys av dette vil følgende problemstilling danne utgangspunkt for kapitlets diskusjon og refleksjon: Hva kjennetegner et profesjonsetisk perspektiv som bidrar til å fremme medborgerskap i omsorgspraksiser sammen med personer med alvorlig utviklingshemming?

Videre i kapitlet vil jeg vil sette de tre berøringspunktene i sammenheng med menneskerettslige og allmenne teoretiske perspektiver knyttet til menneskeverd, rasjonalitet, sårbarhet, aktørskap og omsorgsetiske perspektiver i lys av fortellingene om Nora og Maria (se neste avsnitt). Nora og Maria tjener som eksempler på personer med alvorlig utviklingshemming ${ }^{2}$ og på hvilke kommunikative, kognitive og helsemessige funksjonsnedsettelser dette innebærer for de barn, unge og voksne det gjelder. Til slutt i kapitlet diskuteres de teoretiske elementene i lys av profesjonsetikk som kan bidra til å fremme medborgerskap, med vekt på fortellinger og forståelser av «den andre», og således fremme menneskeverdet og aktørskapet til barn, unge og voksne med alvorlig utviklingshemming gjennom omsorg og solidaritet.

2 Det understrekes at Nora og Maria, ut fra beskrivelsene i eksemplene, kan sammenfalle med diagnostiske kriterier for alvorlig eller dyp utviklingshemming. 


\section{Barn, unge og voksne med alvorlig utviklingshemming}

\section{Nora og Maria}

Nora 17 år er elev i andre klasse ved en videregående skole. Hun uttrykker seg med lyder og kroppsspråk, sitter i rullestol og beveger på hodet på egen hånd. Hun går i en klasse med flere elever som har ulik grad av utviklingshemming. Nora smiler mye, og læreren hennes forteller at hun stort sett alltid smiler og er blid. Latteren til Nora er smittende, og mange ler med henne. Særlig når noen beveger rullestolen hennes raskt og uventet, ler hun høyt og lenge. Flere av elevene i klassen hennes kommer ofte bort til Nora, stryker henne over det lange håret hennes og prater med henne eller bare står tett ved siden av henne. Når Nora av og til ikke er på skolen, og plassen hennes i klasserommet et tom, er det flere av medelevene hennes som peker på plassen hennes, spør etter henne og gir uttrykk for at de tenker på henne og savner henne. Læreren til Nora forteller følgende:

Nora sprer så mye glede rundt seg i klassen. Men det er jammen ikke så mye Nora kan. Hun kan spise, hun drikker, sover, puster, og så beveger hun på hodet sitt. Men vi ser godt når Nora ikke har det bra. Da ser vi rynken i pannen hennes, at kroppen hennes er urolig. Når Nora er urolig eller har rynker i pannen, er det ofte på grunn av smerter, at hun er misfornøyd, eller at hun ser ut til å tenke på noe. (upublisert feltnotat, Gjermestad, 2009)

Maria er 15 år, og vi kan lese om henne i fotoboken Maria - med ustøe skritt mot voksenliv (Bøe, 2018). ${ }^{3}$ Boken er skrevet og fotografert av hennes far, Magne Geir Bøe. I boken forteller foreldrene at Maria er yngst av tre søsken, og at hun er, som ungdom flest, opptatt med egne interesser. Vi får vite at Maria elsker hunder og å leke med vann. Det beste hun vet, er å sitte på stuegulvet med favorittingene sine rundt seg. Maria beskrives som et lite barn i en voksen kropp - hun trenger hjelp til alt (Frøytlog, 2018, s. 16). I omtale av boken forteller faren: «Maria er annerledes, og hun lever 
et annerledes liv. Men jeg vil vise at det det går an å leve et godt liv med utviklingshemming, både for den som er det, og for familien» (Frøytlog, 2018, s. 16). Videre forteller foreldrene at de har fått et annerledes, men rikere liv ved å være foreldre til et barn med alvorlig utviklingshemming (Bøe, 2018). Selv om livet med Maria ble annerledes enn de hadde tenkt seg, legger de ikke skjul på at det også har vært strevsomt å være foreldre til et barn som Maria. Videre i boken beskrives Maria som en jente som trenger hjelp til alt, samtidig som hennes ressurser, begrensninger og utfordringer beskrives med verdighet og respekt. I introduksjon kan vi lese at intensjonen med boken er å synliggjøre med både tekst og bilder at jenter som Maria er unike, med egne interesser, ressurser og begrensninger, samtidig som de er en del av det menneskelige mangfoldet.

Fortellingene om Nora og Maria gir små glimt inn i livene til mennesker som er svært lite synlige i vårt samfunn (Mansell, 2010; Vorhaus, 2016). Selv om unge kvinner som Nora og Maria er lite synlige i samfunnet, fremgår det av fortellingene at de inngår i betydningsfulle relasjoner til andre mennesker som står dem nær, både i familien og på skolen. Nora og Maria snakkes frem av sine nærpersoner som unike aktører og medborgere som både påvirker menneskene rundt dem og er betydningsfulle for andre, og som mottar og gir omsorg og kjærlighet og viser sin hengivenhet til andre. Videre i kapitlet tar jeg med meg fortellingene som eksempler for å bidra til å holde fast ved hvem det snakkes om, og ved hva som står på spill i møte med grunnleggende diskusjoner knyttet til menneskesyn, verdighet, aktørskap, avhengighet og menneskelig sårbarhet. Men først litt om alvorlig utviklingshemming.

Personer som Nora og Maria utgjør en svært liten del av verdens befolkning. I henhold til gjeldende diagnosesystem, ICD-10 (Verdens helseorganisasjon [WHO], 2010) kan barn, unge og voksne med lignende utfordringer som Nora og Maria, beskrives som personer med utviklingshemming av alvorlig eller dyp grad. Felles for mennesker i denne gruppen er at de har alvorlig nedsatte kognitive og kommunikative funksjoner, ofte kombinert med bevegelsesvansker og helsemessige og somatiske utfordringer. I henhold til ICD-11 (WHO, 2011) påpekes det at alvorlig eller dyp utviklingshemming innebærer en intelligenskvotient (IQ) under 34, og at deres mentale alder er under tre år. Barn, unge og 
voksne personer med alvorlig utviklingshemming formidler seg og kommuniserer i hovedsak med førspråklige, kroppslige og emosjonelle ytringer (Horgen, Slåtta \& Gjermestad, 2010). Disse ytringene er høyst særegne og individuelle og beskrives som deres unike språk (Horgen et al., 2010). Å bli kjent med og skape mening i den enkeltes særegne språk krever tålmodighet og engasjement og er en kjennskap som bygges opp over tid (Horgen et al., 2010).

Barn, unge og voksne med alvorlig utviklingshemming har behov for livslang omsorg og støtte fra andre mennesker. Både det livslange hjelpebehovet og nedsatte kognitive og kommunikative funksjoner kan stå i veien for å betrakte personer med alvorlig eller dyp utviklingshemming som unike personer som er en del av det menneskelige mangfoldet. De reduseres som oftest til mottakere av omsorg og pleie (Mansell, 2010; Simmons \& Watson, 2015).

I henhold til Vorhaus (2016) undervurderes ofte deres intellektuelle kapasitet grunnet uvitenhet, feil, fordommer og konservative og mangelfulle kartleggings- og vurderingsmetoder. Undervurderingen kan føre med seg at deres ressurser og potensial forblir lite utforsket. Dette synliggjør hvordan språket vårt er dominert av medisinske og individuelle forklaringsmodeller for funksjonshemming (Simmons \& Watson, 2015). I den medisinske modellen plasseres vansken(e) utelukkende hos individet. Det er i hovedsak de nedsatte kognitive, kommunikative, rasjonelle og sosiale funksjonene som løftes frem. I et slikt perspektiv står man i fare for å rette oppmerksomheten mer mot utfordringene til personer med alvorlig eller dyp utviklingshemming enn mot deres ressurser, potensial og muligheter.

\section{Menneskeverd, rasjonalitet og aktørskap}

I henhold til grunnleggende menneskerettigheter og konvensjonen om rettighetene til personer med nedsatt funksjonsevne (CRPD) er alle mennesker født frie samt har en iboende og grunnleggende verdighet og rett til liv til tross for nedsatt helse eller funksjon (De forente nasjoner [FN], 1948, 2006). Anerkjennelse av alle menneskers iboende verdighet og menneskelig mangfold understrekes også i Tilverelsens gave (NKR, 2017). 
I teksten tas inkludering av alle mennesker for gitt ved at alle mennesker er skapt i Guds bilde, og kirken tar et oppgjør med medisinske forståelser av funksjonshemming til fordel for relasjonelle forståelser. Oppgjøret innebærer også et språk om allmenn sårbarhet som i større grad imøtekommer alle menneskers iboende verdighet og et mangfold av varierende helse og funksjonsevne: «Med dette følger et skifte i synet på mennesker med nedsatt funksjonsevne, fra å stakkarsliggjøres som noen man skal synes synd på, til å respekteres som medborgere med rettigheter» (NKR, 2017, s. 7).

Dette absolutte menneskeverdet er noe alle mennesker har, i kraft av at de er født mennesker. Menneskeverdet er uforanderlig, det kan ikke mistes eller fratas grunnet nedsatt helse eller funksjon (Barbosa da Silva, 2009; FN, 1948, 2006). Samtidig innehar menneskeverdet også en relativ dimensjon ved at verdighet er noe som realiseres i relasjoner, situasjoner og kontekster. I lys av dette er det iboende, absolutte og ukrenkelige menneskeverdet både vilkårlig og foranderlig og kan fremmes, svekkes eller krenkes i relasjoner. Dette anskueliggjør betydningen av det profesjonelle ansvaret for den andre i omsorgspraksiser sammen med barn, unge og voksne med alvorlig utviklingshemming. Ansvaret for den andre må handle om å fremme medborgerskap, verdighet og aktørskap. Å fremme medborgerskap, verdighet og aktørskap i møte med barn og unge med alvorlig utviklingshemming forutsetter at man ser på dem som unike aktører og medborgere som på sine unike og særegne måte påvirker og samhandler i de relasjonene de inngår i. En viktig forutsetning for dette er forståelsen av aktørskap som relasjonelt fenomen (Markus \& Kitayama, 2003; Stefánsdóttir, Björnsdóttir \& Stefánsdóttir, 2018). Som relasjonelt fenomen må aktørskap betraktes som noe som samskapes i relasjoner med våre signifikante andre: "[A]gency is embedded in all actions and impelled with others in relationships and interactions with others» (Markus \& Kitayama, 2003, s. 2).

Men hva er det som særlig kjennetegner mennesket og menneskeverdet? Funksjonshemmingsteologen Hans Reinders (2008, s. 1) har stilt følgende spørsmål: Hva er et menneske, og hva det er som skiller mennesker fra andre levende vesener? Selv om det mest nærliggende og allmenne svaret på spørsmålet, i henhold til Reinders, er at mennesker skiller seg 
fra andre levende vesener grunnet deres funksjon og evne til blant annet språk, rasjonalitet, vilje og selvforståelse, virker svaret ekskluderende for mennesker som Nora og Maria. Det er ekskluderende fordi det bare er egenskaper som språk, rasjonalitet, vilje og selvforståelse som legges til grunn for det menneskelige. Reinders fortsetter: «... that whatever distinguishes them as human beings, it cannot be found in the human faculties. If it were the human faculties, people with profound disability could at best be understood as 'subnormal' or 'subhuman', but not as human beings» (Reinders, 2008, s. 2). I lys av dette vil Noras og Marias nedsatte kognitive og kommunikative funksjoner brukes til å stille spørsmål ved deres menneskelighet, menneskeverd og aktørskap. Både Hans Reinders (2008) og Eva Kittay (2010) understreker derimot at det er helt andre aspekter enn rasjonelle ferdigheter og evne til kognisjon og kommunikasjon som må legges til grunn for og definerer menneskeverdet til Nora og Maria, nemlig deres evne til tilknytning og til å skape relasjoner med andre mennesker samt deres evne til å berøre andre, og det at de er savnet av andre (Reinders, 2008). Evnen til tilknytning og relasjon og til å motta omsorg fra andre er også løftet frem i Tilvoerelsens gave:

For noen mennesker når ikke potensialet deres noe særlig ut over det å være i live, som for mennesker med alvorlig intellektuell funksjonsnedsettelse. Også i disse tilfellene kan det finnes gaver som andre mennesker har behov for, som gaven det er å være til stede, eller en evne til å svare på oppmerksomhet eller vise tegn til tilknytning eller kroppens harmoniske møte med omsorg fra andre mennesker. (NKR, 2017, s. 15)

Vekten på menneskets rasjonelle funksjoner og egenskaper som fornuft, kognisjon, språk og vilje har vært dominerende i vestlig tradisjon. Oppmerksomheten på rasjonalitet overskygger menneskets kroppslighet og mennesket som kroppslige aktører (Lid, 2008; Rogers, 2017). Slik har forestillinger om det selvstendige, autonome og uavhengige subjektet blitt allmenne «tattforgittheter» som i liten grad er diskutert i lys av alvorlig utviklingshemming. Barn og unge som Nora og Maria passer ikke inn i bildet av det rasjonelle, autonome og selvstendige mennesket. For å få øye på subjektiviteten og aktørskapet til personer med alvorlig utviklingshemming må man blant annet rette søkelyset mot deres kroppslighet 
og væremåter i relasjon til andre mennesker (Kittay, 2010). Særlig den feministiske omsorgsfilosofen Eva Kittay fremhever at det ikke er rasjonelle eller kognitive kapasiteter som definerer et menneskes verdi eller moralske status. Derimot løfter hun frem det fellesmenneskelige utgangspunktet ved evnen til emosjonell tilknytning og det å kunne gi og motta omsorg og kjærlighet (Kittay, 2010). Også i teksten Tilvorelsenes gave understrekes menneskets evne til å ha relasjoner med hverandre, og at dette er en gave mellom mennesker, men at det fordrer at man lytter til hverandres stemmer og til de unike erfaringene som følger med det å leve med funksjonshemming.

Når kirkene lærer seg å lytte til disse stemmene, vil de oppdage at disse menneskene har mange gaver å dele, blant dem gaver som har vokst frem gjennom erfaringene med det å leve med funksjonsnedsettelser.... Andre gaver kan også deles, som når mennesker med sterkt nedsatt intellektuell eller utviklingsmessig funksjonsevne deler gaver som tilknytning og tilstedeværelse til dem rundt seg som tilbyr omsorg og støtte. (NKR, 2017, s. 13)

Fenomenologisk filosofi og dennes vekt på kropp, kroppslig væren og intersubjektiv forståelse av andre mennesker representerer en motsats til rasjonelle perspektiver på aktørskap (Merleau-Ponty, 1994). I et fenomenologisk perspektiv knyttes ikke aktørskap til rasjonalitet og språklige funksjoner, men det argumenteres for at aktørskap er emosjonelt og kroppslig fundert og «embodied» (Merleau-Ponty, 1994). I det kroppslige aktørskapet vektlegges kropp, sanser og emosjoner forut for fornuft, kognisjon og rasjonelle funksjoner. Videre innebærer kroppslig aktørskap at hele kroppen formidler seg i møte med andre mennesker. Dette innebærer anerkjennelse av at de førspråklige, nonverbale og emosjonelle ytringene sammen med lyder, kroppsspråk og bevegelser utgjør et viktig fundament i det kroppslige aktørskapet til barn, unge og voksne personer med alvorlig utviklingshemming. Når aktørskap er noe som skapes i relasjon med nære omsorgspersoner og signifikante andre, synliggjøres også betydningen av intersubjektivitet. Moderne spedbarnsforskning har frembrakt kunnskap om alle menneskers medfødte intersubjektive og sosiale kompetanse samt vår umiddelbare forståelse og opplevelse av den andre (Bråten, 2000; Stern, 1985; Trevarthen, 1979). Intersubjektivitet 
viser her til et opplevelsesfellesskap mellom to personer, hvor forståelse av hverandre skapes gjennom sympatisk medopplevelse som er kroppslig fundert (Bråten, 2000; Stern, 1985; Trevarthen, 1979). Empiriske studier viser at dette intersubjektive opplevelsesfellesskapet er en ressurs for kommunikasjon og meningsskaping mellom barn, unge og voksne med alvorlig utviklingshemming og deres nærpersoner (Gjermestad, 2009; Simmons \& Watson, 2015).

Aktørskap er med andre ord så mye mer enn språk, kognisjon og rasjonelle egenskaper. I eksemplene med Nora og Maria ser vi at de snakkes frem som aktører av sine nærpersoner i familien og på skolen. I tillegg illustrerer eksemplene deres unike evner til å berøre andre mennesker at de betyr noe for andre, beveger andre, inngår i relasjon til andre og vekker følelser som glede, takknemlighet og savn hos mennesker de omgås. Samtidig som betydningen av intersubjektivitet og kroppslighet er avgjørende for å synliggjøre aktørskapet til Nora og Maria, må også aktørskap forstås som grunnleggende relasjonelt, noe som skapes i relasjoner og interaksjoner mellom mennesker (Stefánsdóttir, Björnsdóttir \& Stefánsdóttir, 2018). Ingen kan være aktør alene, alle menneskers aktørskap forvaltes og realiseres i relasjoner med andre.

\section{Sårbarhet}

Tankegodset fra feministisk filosofi og omsorgsteori retter et kritisk blikk mot og utfordrer forestillinger om den selvstendige, uavhengige, rasjonelle og autonome og individuelle medborger. I Kittay sitt feministiske bidrag pekes det særlig på betydningen av fellesmenneskelig avhengighet og sårbarhet ved at alle mennesker er avhengig av omsorg hele livet igjennom (Kittay, 2010). Alle menneskers omsorgsbehov og avhengighet til andre varierer igjennom livet - fra «vugge til grav». Det er imidlertid lett å tenke at barn, unge og voksne med alvorlig utviklingshemming er svært sårbare grunnet store hjelpebehov, nedsatte funksjoner og helsemessige utfordringer. Men hva er sårbarhet? Er sårbarhet noe mennesker er, eller er sårbarhet et produkt av bestemte omstendigheter i menneskers liv?

Intuitivt knyttes som oftest sårbarhet an til marginaliserte og utsatte personer eller grupper grunnet sykdom, funksjonshemming, økonomiske 
eller sosiale utfordringer. Vi kan skille mellom sårbarhet forstått som fellesmenneskelig fenomen og som relativt fenomen (Kermit, 2018). Som fellesmenneskelig fenomen ligger det til grunn en forståelse av at alle mennesker er sårbare og utlevert og lever liv avhengig av hverandre. Som relativt fenomen legges det til grunn at «sårbar» ikke er noe man er, men at sårbarhet er et produkt av situasjoner, kontekster og omstendigheter i menneskelige fellesskap og omgivelsene man inngår i. Sårbarhet som en fellesmenneskelig verdi knytter an til at alle har en kropp, helse og funksjoner som endrer seg gjennom livet. Vi lever alle liv hvor vi er avhengig og sårbare overfor funksjonsnedsettelse og sykdom, og alle mennesker lever liv i nærhet og gjensidig avhengighet til hverandre (Lid, 2008, 2016; Rogers, 2017). Det argumenteres også for en slik fellesmenneskelig forståelse av sårbarhet i Tilvorelsens gave. Det kan imidlertid ligge en fare i å knytte sårbarhet til særlige trekk ved mennesker eller grupper, slik som eksempelvis sykdom eller funksjonshemming, noe som kan bidra til at sårbarhet reduseres til noe en person er: «Når sårbarhet knyttes kun til mennesker med funksjonsnedsettelser, skapes et falskt inntrykk av at mennesker uten funksjonsnedsettelser er sterke og klarer seg selv» (NKR, 2017, s. 18).

Med andre ord er det ikke bare personer som Nora og Maria som er avhengig av støtte og hjelp fra andre. Det gjelder oss alle, men i varierende grad. Det innebærer at vi alle lever sårbare og utsatte liv, og sårbarhet er således noe alle mennesker har konkrete erfaringer med og kan kjenne seg igjen i: «Vi er alle skapt som forgjengelige vesener, og vi lever alle med begrensninger av forskjellige slag (NKR, 2017, s. 8). Om vi tenker på helseutfordringer, nedsatte funksjoner og sårbarhet som noe fellesmenneskelig, som noe som alle mennesker har erfaringer med, betyr det at sårbarheten til Nora og Marie ikke blir så fremmed, men noe man kan kjenne seg igjen i. Ved å søke å forstå sårbarhet som noe allment, kan forståelsen være en ressurs som bidrar til å dempe forskjeller, stigma og annerledesheten til mennesker som Nora og Maria.

Den feministiske funksjonshemmingsforskeren Rosemarie GarlandThomson (2010) understreker at vi er alle sårbare og utsatte som mennesker, og at funksjonshemming er en del av menneskelig variasjon og mangfold. Ifølge henne er vi alle mennesker som har kropper som 
endres, kroppene våre er «temporarily abled bodies» - midlertidig funksjonsdyktige kropper (Garland-Thomson, 2010). I likhet med Garland-Thompson peker også den norske teologen Sturla Stålsett (2012) på at sårbarheten er en ressurs vi har oss mennesker imellom. Han viser også til at sårbarhet er en del av de menneskelige grunnvilkårene og verdiene i det menneskelige felleskapet. Vi er alle utlevert til hverandre med hverandres sårbarhet, og derfor må vi betrakte sårbarhet som noe vi mennesker deler.

\section{Et bidrag til et profesjonsetisk språk som fremmer medborgerskap}

Profesjonelle omsorgsutøvere har dypest sett et moralsk samfunnsoppdrag om å ta vare på velferden til borgere som har behov for hjelp og støtte (Martinsen, 2000; Nortvedt, 2007). Omsorg er å handle til den andres beste. Men hva den andres beste innebærer, kan man ikke vite på forhånd - det må skapes i hver enkelt situasjon. Helsepersonell skal i henhold til helse- og omsorgstjenesteloven og helsepersonelloven yte både fagligforsvarlig og omsorgsfull hjelp (helse- og omsorgstjenesteloven, 2011; helsepersonelloven, 1999), og den omsorgsfulle hjelpen skal ytes på måter som viser omtanke og respekt for den enkelte, og som ikke krenker dennes personlige integritet. Den norske omsorgsfilosofen Kari Martinsen peker på at god omsorg handler om å være både sanselig og faglig orientert mot den andre. I tillegg må man være bevisst på at både den profesjonelle omsorgsutøveren og omsorgsmottakeren er medmennesker med felles grunnerfaringer av å være nettopp medmenneske (Martinsen, 2000). Det sanselige handler om solidaritet med den andre samt om å ta inn over seg den andres situasjon og smerte, og om å sanse hvordan det er å være i den andres sko.

I et profesjonsetisk lys er det nærliggende å reflektere over hvilke teoretiske perspektiver og grunnleggende verdier som bør ligge til grunn for gode omsorgspraksiser, slik at velferden til dem det gjelder, realiseres (Aadland, 2018). For at den profesjonelle skal kunne sikre velferd og handle til den andres beste, må handlingene, væremåtene og de faglige valgene være både teoretisk og verdimessig informert. Jeg har så langt 
i kapitlet pekt på både teologiske og allmenne teoretiske perspektiver knyttet til menneskeverd, rasjonalitet, aktørskap og sårbarhet, som må ligge til grunn for gode profesjonelle omsorgspraksiser sammen med barn, unge og voksne med alvorlig utviklingshemming. Videre vil jeg diskutere hvordan disse perspektivene kan gi verdifulle profesjonsetiske perspektiver og bidra til et profesjonsetisk språk innenfor dette feltet.

\section{$\AA ̊ ̊ n$ handle til den andres beste gjennom å skape motfortellinger}

Som nevnt innledningsvis er den profesjonelles syn på og forestillinger om den man yter omsorg til, av stor betydning for å kunne anerkjenne den det gjelder, og for kvaliteten på omsorgsarbeidet som utøves (Rogers, 2017). I omsorgspraksiser med personer med alvorlig utviklingshemming utfordres både vår forståelse av sårbarhet og vårt syn på mennesket og menneskeverdet. Personer med alvorlig utviklingshemming er avhengig av omsorg og bistand hele livet igjennom fra både familie og profesjonelle omsorgsutøvere (Horgen, Slåtta \& Gjermestad, 2010; Vorhaus, 2016). Våre indre forestillinger, verdier og menneskesyn inngår som implisitte og tause dimensjoner ved omsorgspraksisene som vi er en del av (Barbosa da Silva, 2009; Rogers, 2017). Omsorgspraksiser med personer med alvorlig utviklingshemming er således møter hvor medborgerskap og aktørskap overfor enkeltmennesker kan fremmes, men også hemmes. Av den grunn er det særlig betydningsfullt å utforske allmenne forestillinger av barn, unge og voksne personer med utviklingshemming.

Språket er sentralt med tanke på hvordan vi forstår og skaper forestillinger om andre mennesker, og det er nært knyttet til hvilke fortellinger vi forteller om hverandre, både i profesjonelle og i private sammenhenger. Alle mennesker omgis av et vell av fortellinger. Vanligvis forteller mennesker sine fortellinger selv, og de fleste kan bidra til å korrigere, justere eller skape motfortellinger om seg selv og andre (Bamberg \& Andrews, 2004). Slike motfortellinger kan utfordre forestillinger om oss selv som ofte er feilaktige og tatt for gitt. Barn, unge og voksne med 
alvorlig utviklingshemming har imidlertid ikke muligheter til å fortelle eller konstruere sin egen fortelling i språklig forstand (Grove, 2012; Swinton, Mowat \& Baines, 2011). De barna og de unge og voksne det her er snakk om, står i fare for å bli utsatt for feilaktige fremstillinger og fortellinger hvor deres hjelpeavhengighet, diagnoser og avvik er i søkelyset. Likeledes har de få muligheter til å skape språklige motfortellinger som utfordrer stigmatiserende og reduksjonistiske forestillinger som skygger for deres aktørskap og subjektivitet og for de unike personlighetene de er. Men sammen med nærpersoner og signifikante andre blir det imidlertid mulig å tolke og skape mening i de kroppslige og emosjonelle ytringene til barn, unge og voksne med alvorlig utviklingshemming, slik at deres aktørskap kommer til syne (Fjetland \& Gjermestad, 2018; Gjermestad, 2017). Som profesjonelle omsorgspersoner blir man på denne måten viktige bærere og formidlere av både deres fortellinger og deres motfortellinger. Og det moralske ansvaret $\mathrm{i}$ et profesjonsetisk lys handler om å frembringe slike fortellinger og skape motfortellinger som fremmer disse menneskenes medborgerskap og aktørskap. I lys av Tilvorelsens gave vil den profesjonelles motfortellinger berikes ved at de funderes i livets ukrenkelige verdi, som er gitt i gave til alle, samt i alle menneskers sårbarhet og variasjoner i funksjon. Fortellingene som fortelles om Nora og Maria, er eksempler på slike motfortellinger.

For å bevisstgjøre helse- og omsorgspersonell om det profesjonelle ansvaret for «den andre» i møte med barn, unge og voksne med alvorlig utviklingshemming trengs et språk for å forstå den andres menneskeverd, aktørskap og medborgerskap - et språk som kan romme og fremme dette. Filosofen Inga Bostad (2013), som selv er mor til en ung kvinne med multifunksjonshemming, maner til bevissthet om at språket vårt og måten vi snakker om barn, unge og voksne med multifunksjonshemming på, kan bidra både til å muliggjøre, men også til å krenke og invalidisere den det gjelder. Hun løfter frem behovet for et språk som åpner opp for mulighetsrom, mangfold og ressurser: «Vi kan snakke om et språk som både kan muliggjøre og invalidisere (... ), og det barnet som er annerledes, trenger å omgis av et språk, og en fortelling om seg selv som er åpen for en god fremtid, som har et mulighetsrom, er mangfoldig og som ikke lukker og begrenser» (Bostad, 2013, s. 6-8). 


\section{Å fremme menneskeverd og aktørskap gjennom fortellersamarbeid}

Omsorgsteori fremhever omsorg mellom mennesker som et grunnleggende trekk ved det å være menneske, en del av den menneskelige væren, en eksistensform (Martinsen, 200o). I dette ligger en forståelse av at omsorg er en del av alle relasjoner, en ressurs og en kilde til støtte, solidaritet, beskyttelse og forståelse av både den omsorgstrengende og den som yter omsorg. Omsorg som ressurs mellom mennesker blir således en mulighetsbetingelse for å realisere andres velferd, aktørskap og medborgerskap. Både profesjonelle, familie og nærpersoner er sentrale i å muliggjøre aktørskapet til personer med alvorlig utviklingshemming. For å realisere dette profesjonsetiske ansvaret må den profesjonelle gjøres bevisst på sin dialogiske og narrative kompetanse (Fjetland \& Gjermestad, 2018). Den dialogiske og narrative kompetansen som Fjetland og Gjermestad påpeker at medborgerskap og aktørskap er, er grunnleggende intersubjektiv og dialogisk og fremmes gjennom et fortellersamarbeid mellom personer med alvorlig utviklingshemming og den profesjonelle.

For at Nora og Maria skal bli sett, forstått og fremstå som aktører og medborgere, er det nødvendig at deres nærpersoner innehar et profesjonsetisk språk hvor de er seg bevisst betydningen av narrativ og dialogisk kompetanse (Fjetland \& Gjermestad, 2018). Den dialogiske og narrative kompetansen hos nærpersoner og profesjonelle knytter an til å formidle og skape mening i de førspråklige og kroppslige ytringene til barn, unge og voksne med alvorlig utviklingshemming. Det å tolke og skape mening i de kroppslige ytringene er en dialogisk, kroppslig og intersubjektiv prosess som krever tid og engasjement. Fortellersamarbeidet må være fundert i en grunnleggende forståelse av menneskeverd, funksjonshemming og sårbarhet som ikke reduserer og skaper avstand til barn, unge og voksne personer med utviklingshemming, men som heller åpner for det allmenne, for likheter og for anerkjennelse av mangfold og fellesmenneskelig sårbarhet.

Det er imidlertid viktig å understreke at til tross for at man etter beste evne forsøker å forstå og leve seg inn i den andres situasjon og ta den andres perspektiv, må det alltid gjøres med åpenhet for et mangfold av 
tolkninger. I mangfoldet av tolkninger kreves at den profesjonelle har en åpenhet overfor muligheten for at man kan misforstå og tolke den andres nonverbale og kroppslige ytringer feilaktig. I daglig samspill og omsorgspraksiser med barn, unge og voksne med alvorlig utviklingshemming vil det alltid være overhengende fare for at man kan ha forstått og tolket den andre feilaktig, selv om det skjer i den beste mening. Både nærpersoner og profesjonelle står i fare for å la egne preferanser prege tolkningen av ytringene til barn, unge og voksne med alvorlig utviklingshemming. Samtidig representerer mangfoldet av tolkninger en ressurs i det å komme tett på perspektivet til barn, unge og voksne med alvorlig utviklingshemming.

\section{Oppsummering}

Med inspirasjon fra den teologiske teksten Tilverelsens gave og allmenne teoretiske perspektiver på menneskeverd, sårbarhet og aktørskap har jeg i dette kapitlet reflektert over hvordan disse perspektivene kan informere og gi innhold til et profesjonsetisk språk som fremmer medborgerskap i møte med barn, unge og voksne personer med alvorlig utviklingshemming. I kapitlet har jeg tatt til orde for å utfordre allmenne og selvfølgelige forestillinger om barn, unge og voksne med alvorlig utviklingshemming. Dette har jeg gjort med håp om å bidra til et språk som synliggjør, anerkjenner og yter rettferdighet overfor menneskeverdet til barn, unge og voksne personer med alvorlig utviklingshemming. Et språk som anerkjenner deres unike aktørskap som medborgere med muligheter, potensial og unike væremåter, og som er en del av det menneskelige mangfoldet. Et språk som utgjør motfortellinger, og som utfordrer tanken om at sårbarhet er knyttet til funksjonsnedsettelse. Det er ikke først og fremst er de kognitive funksjonene språk, rasjonalitet og vilje som definerer menneskelighet, dersom vi forstår aktørskap kroppslig.

Til tross for at profesjonsetikken skal være livssynsnøytral, kan den teologiske teksten Tilverelsens gave tjene som en faglig og etisk ledestjerne i det profesjonelle omsorgsarbeidet med denne gruppen mennesker fordi den berører sentrale allmenmenneskelige verdier. Jeg har forsøkt å vise hvordan disse verdiene kan åpne for en rikere forståelse av menneskesyn 
og medborgerskap overfor denne gruppen. En slik kunnskapsmessig og verdimessig forankring er for det første et bidrag til å stimulere til kunnskapsbaserte og verdimessige diskusjoner knyttet til det profesjonelle ansvaret helse- og omsorgspersonell har overfor barn og voksne med alvorlig utviklingshemming. For det andre er denne kunnskapen også viktig for å skape bevissthet om hvordan aktørskap, medborgerskap og velferd kan fremmes i profesjonelle omsorgspraksiser.

\section{Referanser}

Aadland, E. (2018). Etikk i profesjonell praksis. Oslo: Samlaget.

Aakre, M. (2016). Jakten på dømmekraft. Praksisnort etikkarbeid i helsetjenesten. Oslo: Gyldendal Akademisk.

Bamberg, M. \& Andrews, M. (2004). Considering counter-narratives: Narrating, resisting, making sense. Amsterdam: John Benjamins.

Barbosa Da Silva, A. (2009). Autonomy, dignity and integrity in health care ethics - a moral philosophical perspective. I H. Sinding Aasen, R. Halvorsen \& A. Barbosa da Silva (Red.) (2009), Human rights, dignity and autonomy in health care and social services. Nordic perspectives. Cambrigde, England: Intersentia Publishers.

Bostad, I. (2013). Spesialpedagogikk i praksis - et foreldreperspektiv. Spesialpedagogikk, 78(4), 6-11.

Botnen Eide, S. (2018). Etikk og profesjonsutøvelse eller etikk i profesjonsutøvelse. I K. Hjort, A. Kristiansen \& N. C. Barkholt (Red.), Profesjonsetikk. Velferdsarbeid for og med mennesker. Oslo: Gyldendal.

Bøe, M. G. (2017). Maria - med ustøe skritt mot voksenliv (ISBN 978-82-690871-0-9). magneboe-photography.com

Curtis, B. \& Vehmas, S. (2014). Moral worth and severe intellectual disability - a hybrid view. I J. E. Bickenback, F. Felder \& B. Schmitz (Red.), Disability and the good human life. Cambridge, England: Cambridge University Press.

Fjetland, K. J. \& Gjermestad, A. (2018). Medborgerskap og alvorlig utviklingshemming. Tidsskrift for velferdsforskning, 21(2), 148-62.

FN. (1948). Menneskerettighetserkloeringen.

FN. (2006). FN-konvensjon om rettigheter til personer med funksjonsnedsettelser.

Frøytlog, B. (2018, 6. januar). Store lille Maria. Magasinet - Dagbladet. Hentet fra http://sibs.frambu.com/wp-content/uploads/2018/o9/store-lille-maria-dagbladeto1-nyhetsklipp-o6-01.pdf

Garland-Thomson, R. (2010). Misfits: A feminist materalist disability concept. Hypathia, 26(3), 591-609. 
Gjermestad, A. (2009). Skjøre samspill. En deskriptiv og fortolkende studie av barn med dyp utviklingshemming og deres noerpersoner i barnehage og skole. Doktorgradavhandling nr. 83, 2009. Stavanger: Det humanistiske fakultet, Universitetet i Stavanger.

Gjermestad, A. (2017). Narrative competence in caring encounters with persons with profound intellectual and multiple disabilities. International Practice Development Journal, 7(7), 1-11.

Grove, N. (2012). Story, agency, and meaning making: Narrative models and the social inclusion of people with severe and profound intellectual disabilities. Journal of Religion, Disability \& Health, 16(4), 334-351.

Hanisch, H. (2014). Recognizing disability. I J. E. Bickenback, F. Felder \& B. Schmitz (Red.), Disability and the good human life. Cambridge, England: Cambridge University Press.

Helse- og omsorgstjenesteloven. (2011). Lov om kommunale helse- og omsorgstjenester. (LOV-2011-o6-24-30). Hentet fra https://lovdata.no/dokument/ NL/lov/2011-06-24-30

Helsepersonelloven (1999). Lov om helsepersonell m.v. (LOV-1999-07-02-64) Hentet fra https://lovdata.no/dokument/NL/lov/1999-07-02-64

Horgen, T., Slåtta, K. \& Gjermestad, A. (2010). Multifunksjonshemming - livsutfoldelse og loering (s. 15-19). Oslo: Universitetsforlaget.

Kermit, P. (2018). Forståelser av begrepet sårbarhet i lys av forskningsetiske tradisjoner. I B. Berg, G. M. D. Haugen, K. Elvegård \& P. Kermit (Red.), Marginalitet, sårbarhet, mestring. Metodiske utfordringer i praksisnor forskning. Oslo: Universitetsforlaget.

Kittay, E. F. \& Carlson, L. (Red.) (2010). Cognitive disability and its challenge to moral philosophy. Oxford: Wiley-Blackwell.

Kittay, E. F. (2010). The personal is philosophical is political: A philosopher and mother of a cognitively disabled person sends notes from battlefield. I E. F. Kittay \& L. Carlson (Red.), Cognitive disability and its challenge to moral philosophy (s. 393-413). Oxford, England: Wiley-Blackwell.

Lid, I. M. (2008). Funksjonshemming og menneskesyn. Kirke og kultur, (6), 513-521.

Lid, I. M. (2016). Vulnerability and disability: A citizenship perspective. Disability \& Society, 30(10), 1554-1567.

Mansell, J. (2010). Raising our sights: Service for adults with profound intellectual and multiple disability (rapport). Canterbury, England: Tizard Centre, University of Kent.

Markus, H. R. \& Kitayama, S. (2003). Models of agency: Sociocultural diversity in the construction of action. I V. Murphy-Berman \& J. J. Berman (Red.), Nebraska symposium on motivation: Cross-cultural differences in perspectives on the self (s. 1-58). Lincoln, NE: University of Nebraska Press. 
Martinsen, K. (200o). Øyet og kallet. Bergen: Fagbokforlaget.

Merleau-Ponty, M. (1994). Kroppens fenomenologi. Oslo: Pax Forlag.

Norges Kristne Råd [NKR]. (2017). Tilvorelsens gave. Kalt til å væere kirke av alle og for alle. Norges Kristne Råds skriftserie, nr. 20. Oslo: Norges Kristne Råd.

NOU 2016: 17. (2016). På like linje. Åtte løft for å realisere grunnleggende rettigheter for personer med utviklingshemming. Oslo: Departementenes sikkerhets- og serviceorganisasjon, Informasjonsforvaltningen.

Nordtvedt, P. (2007). Den etiske fordring - omsorgens kjerne. I D. Bugge \& P. Aaboe Sørensen (Red.), Livtag med den etiske fordring. Århus: Forlaget Klim

Reinders, H. S. (2008). Receiving the gift of friendship. Profound disability, theological anthropologicy and ethics. Grand Rapids, MI: Wm. B. Eerdsman Publishing \& Co.

Rogers, C. (2017). Intellectual disability and being human. London: Routledge.

Simmons, B. \& Watson, D. (2015). From individualism to co-construction and back again: Rethinking research methodology for children with profound and multiple learning disabilities. Child and Care Practice, 21(1), 50-66.

Singer, P. (2010). Speciesism and moral status. I E. F. Kittay, \& L. Carlson (Red.), Cognitive disability and its challenge to moral philosophy (s. 331-344). Oxford, England: Wiley-Blackwell.

Stefánsdóttir, G., Björnsdóttir, K. \& Stefánsdóttir, Á. (2018). Autonomy and people with intellectual disabilities who require more intensive support. Scandinavian Journal of Disability Research, 20(1), 162-171.

Stålsett, S. (2012). Asylbarn og menneskeverd. Etiske refleksjoner med utgangspunkt i erfaringer fra Helsesenteret for papirløse migranter. Etikk i praksis. Nordic Journal of applied Ethics, 6(2), 23-37.

Swinton, J., Mowat, H. \& Baines, S. (2011). Whose story am I? Redescribing profound intellectual disability in the kingdom of God. Journal of Religion, Disability \& Health, (15), 5-19.

Vorhaus, J. (2015). Giving voice to profound disability. Dignity, dependence and human capability. London, England: Routledge.

Watson, J. (2016). Assumptions of decision-making capacity: The role supporter attitudes play in the realisation of article 12 for people with severe or profound intellectual disability. Laws, 5(1), 1-9. https://doi.org/10.3390/laws5010006 WHO. (2018). Classification of diseases (ICD-11). 


\title{
KAPITTEL 4
}

\section{Taktil teologi: Om kirkerom og mangfoldige estetiske uttrykk}

\section{Leonora Onarheim Bergsjø}

\section{Universitetet i Oslo}

\begin{abstract}
Thresholdless churches can improve accessibility, but how can churches express that variations in abilities are fundamental to human life? In this article, theological aesthetics and disability aesthetics are used to explore this question through an investigation of a church designed especially for deaf and deafblind persons, Tomaskirken in Andebu, Norway. Based on the observation that the interior of the church lacks references to disability art and disability aesthetics, it is argued that this is problematic. Altough the lack of disability aesthetics and disability art can be understood as a sign of inclusion, Tomaskirken remain a missed opportunity to explore how the theological acknowledgement of human diversity can be expressed through aesthetic expressions in churches.
\end{abstract}

Keywords: theology, disability, aesthetics, Tomaskirken, Signo

\section{Innledning}

Tilverelsens gave (Norges Kristne Råd [NKR], 2017) er uttrykk for et internasjonalt, felleskirkelig arbeid for å anerkjenne at variasjoner av funksjonsevne og -nivå er et grunnleggende vilkår for menneskelivet. Den norske kirke har også rettet stadig mer oppmerksomhet mot dette, og det påvirker blant annet utformingen av kirkerommene. Kirken vil ikke bare gjøre kirkene mer fysisk tilgjengelige, men også vise et estetisk mangfold av uttrykk, inkludert taktil kunst. Satsingen til Den

Sitering av denne artikkelen: Bergsjø, L. O. (2020). Taktil teologi: Om kirkerom og mangfoldige estetiske uttrykk. I I. M. Lid \& A. R. Solevåg (Red.), Religiøst medborgerskap: Funksjonshemming, likeverd og menneskesyn (Kap. 4, s. 89-105). Oslo: Cappelen Damm Akademisk. https://doi.org/10.23865/ noasp.10o.ch 4

Lisens: CC BY-NC-ND 4.o. 
norske kirke har vært rettet mot fysisk utforming, mer enn teologisk innhold. Arbeid med estetisk mangfold er imidlertid en mulighet til å videreutvikle teologien, og denne muligheten for teologisk utviklingsarbeid knyttet til teologi og berøring er det overordnede temaet for dette kapitlet.

Spørsmålet om hvorvidt estetiske uttrykk kan gi åndelig erfaring og bidra til forkynnelsen av evangeliet, står i sentrum i teologisk estetikk («theological aesthetics») (Viladesau, 2000; Thiessen, 2004). Innenfor dette fagfeltet undersøkes forholdet mellom teologiske emner og sanselig erfaring. Gesa Elsbeth Thiessen skriver i boken Theological Aestetics: A reader at «teologisk estetikk undersøker spørsmål om Gud og teologiske temaer i lys av sanselig erfaring [sense knowledge] (sansning, følelser og imaginasjon), gjennom skjønnhet og kunstene» (Thiessen, 2004, s. 1, min oversettelse). Innenfor protestantisk teologi finner vi teologisk estetikk i praktisk teologi og religionspedagogikk, men også systematisk teologi (Redeker, 2011; Jørgensen, 2014). Kunst og kirkerom er ofte objekter i teologisk-estetiske undersøkelser, og det skal de også være her i denne systematiske, teologisk-estetiske undersøkelsen av et kirkerom.

Til tross for at erfaring og livsvilkår står sentralt i protestantisk teologisk estetikk, er fagfeltet i liten grad informert av funksjonshemmingsstudier, funksjonshemmingsteologi og funksjonshemmingsestetikk (Bergsjø, 2016). Her er det en viktig mulighet til samarbeid og fornyelse. Når kirker skal tilrettelegges for å gi åndelig erfaring gjennom sansene, er det viktig å diskutere variasjon av sanselig erfaring, og hva det betyr i praksis. Hva som er «mangfoldige sanselige uttrykk», kan forstås på forskjellige måter, og forståelsen kan igjen få konsekvenser for hvilken teologi som reflekteres i de konkrete sanselige uttrykkene.

Materialet i denne undersøkelsen er Tomaskirken i Andebu i Vestfold og Telemark, som ble vigslet i 2012. Tomaskirken er spesielt tilrettelagt for døve, hørselshemmede og døvblinde og er bygd av stiftelsen Signo, som arbeider for og med denne gruppen mennesker. Dette burde gi gode forutsetninger for å skape både en kirke som reflekterer gruppen og en teologi som er særlig sensitiv overfor deres utfordringer. Det gjør også kirken til en spesielt interessant case i diskusjonen om sanselig og åndelig erfaring 
i kirkerommet. Kirken presenteres kort i første del av dette kapitlet. Noen hovedelementer i kirken analyseres i kapitlets andre del, «Et kirkerom for sansning». I kapitlets tredje del, «Berøringens teologi» diskuteres de mangfoldige estetiske uttrykkene i Tomaskirken nærmere.

\section{Del 1: Kirke, teologi og kunst}

\section{En sansekirke}

Tomas, en av de tolv, han som ble kalt Tvillingen, var ikke sammen med de andre disiplene da Jesus kom. "Vi har sett Herren», sa de til ham. Men han sa: "Dersom jeg ikke får se naglemerkene $i$ hendene hans og får legge fingeren i dem og stikke hånden $i$ siden hans, kan jeg ikke tro.» Åtte dager senere var disiplene igjen samlet, og Tomas var sammen med dem. Da kom Jesus mens dørene var lukket. Han sto midt iblant dem og sa: «Fred voere med dere.» Så sier han til Tomas: «Kom med fingeren din, se her er hendene mine. Kom med hånden og stikk den i siden min. Og vor ikke vantro, men troende!» «Min Herre og min Gud!» sa Tomas. Jesus sier til ham: «Fordi du har sett meg, tror du. Salige er de som ikke ser, og likevel tror.» (Joh 20, 24-29)

Tomaskirken er en «sansekirke» bygd spesielt for mennesker med funksjonsnedsettelser. Arkitekten er Wenche Hillestad ved arkitektfirmaet A-Tre konsult, og kirken er utformet i dialog mellom arkitekten og Kirkelig Kulturverksted ved Berit Hunnestad. Noe av inventaret er lagd på verksteder for og av mennesker med funksjonsnedsettelser. Kirken en del av skole- og kompetansesenteret til Signo, tidligere Hjemmet for døve, som er en stiftelse som gir tegnspråklige tilbud til døve, hørselshemmede og døvblinde på vegne av det offentlige (se signo.no). Beboerne på Signos kompetansesenter er mennesker som er døve, hørselshemmet eller døvblinde, og flere har også kognitive funksjonsnedsettelser.

Kirken kan forstås som en konkretisering av et av Signos formål, som er å tilrettelegge for åndelig praksis (Lid, 2018). Signo kaller kirken verdens første sansekirke fordi den ble laget med særlig vekt på å kunne gi en åndelig opplevelse for døvblinde. Kirkerommet er laget for dem som «bruker hendene til å oppleve, lytte, se og bli forstått» (se tomaskirken.no). 
Kirken er oppkalt etter disippelen Tomas, som ifølge Johannesevangeliet ikke ville tro før han fikk legge fingeren i Jesu naglemerkede hender (Joh 20, 24-31). Å legge fingeren i håndflaten (peke på naglemerket) betyr «Jesus» på tegnspråk (Lid, 2018). Tegnet viser til fortellingen om Jesu lidelser, men også til Peters konkrete sanselige erfaring av den oppstandne. Med fortellingen følger spørsmålet om hva som skal til for å tro på forkynnelsen.

Signo er tilknyttet Den norske kirke og har ansatt en egen prest. I Tomaskirken holder presten jevnlig gudstjenester og forretter andre kirkelige handlinger. Gudstjenestene er kortere enn det som ellers er vanlig i Den norske kirke (Lid \& Bergsjø, 2018). Mange av beboerne på senteret er medlemmer av Den norske kirke, men ikke alle. I praksis har derfor kirken en økumenisk kristen bruk.

Til kirken hører det også en kirkestue der det er både sosialt samvær i forbindelse med gudstjeneste, opplæring av studenter og foredrag. Utenom gudstjenestene er kirken åpen for besøk fra beboere på senteret, pårørende og ansatte. Andre interesserte kan komme etter avtale. I tillegg brukes kirken til sansetrening for fagpersonell som skal arbeide med døvblinde (Lid \& Bergsjø, 2018, s. 241). Studenter får blant annet utforske rommet med bind for øynene. Rommet har med andre ord en viktig funksjon også utenfor den religiøse rammen som de kirkelige handlingene gir.

Siden kirken ble tatt i bruk, har det kommet flere endringer og oppgraderinger i kirkerommet. Signo prøver stadig ut nye måter å tilrettelegge for målgruppen på ved å endre interiøret. Disse endringene er altså ikke utvikling av kirkelige handlinger, men utgjør den fysiske rammen for handlingene. Dette kan ses som et uttrykk for ideen om at rommet $i$ seg selv kan være en kilde og bidra til åndelig erfaring.

\section{Teologi i utformingen av kirkerommet}

Det er ikke bare i Signo man tenker at kirkerommet i seg selv kan bidra til eller gi en åndelig erfaring. Spørsmålet om hvilken erfaring som er av betydning for utvikling av troen, er like gammelt som teologien selv og er konkretisert i teologisk estetikk, feltet som Urs von Balthasar regnes 
som grunnlegger av (Balthasar, 1961; Bychkow, 2008). Teologisk estetikk handler om å undersøke sammenhengen mellom Gud og estetisk erfaring (Thiessen, 2010, s. 1). Estetisk erfaring er en sanselig erfaring som gir erkjennelse (Jørgensen, 2014). Fordi estetisk erfaring gir erkjennelse, er den en kilde til forståelse på linje med empirisk erfaring, men den gir en annen type erkjennelse (Jørgensen, 2014).

Hvilken sanselig erfaring som kan gi åndelig erkjennelse, er et viktig spørsmål i teologisk estetikk, og her finnes det to hovedskoler (Bychkow, 2008). Balthasar tar utgangspunkt i Guds herlighet og det som er åpenbart, og hans estetiske teologi er tekstbasert og konseptuell. Alternativet er å ta utgangspunkt i det skapte og i livserfaringen. Det er denne retningen som har dominert diskursen i protestantisk teologisk estetikk i Norge de siste tiårene (Jørgensen, 2014; Bergsjø, 2016). Det vil si at estetisk erfaring gjort i naturen, med kunst eller arkitektur, kan være kilde til teologi, likesom evangeliene er det. I dette perspektivet er kirkerommet av betydning for formidlingen av evangeliet (Sandal, 2014).

Tanken er altså at rommets fysiske utforming ikke bare gjenspeiler en teologisk forståelse, men også i seg selv er en kilde til teologisk forståelse. Da blir det viktig hvordan kirkerommet er utformet. Det skal ikke bare gi en god praktisk ramme for de kirkelige handlingene som finner sted, et prinsipp som gjenspeiles i mange norske kirker («arbeidskirker») bygget i andre halvdel av det tjuende århundre. Rommet skal også ha et aktivt forhold til et kristent verdenssyn og menneskebilde. For eksempel kan kirkerommet vise at kirken er åpen for alle mennesker når det er universelt tilrettelagt. Å inkludere et mangfold av estetiske uttrykk er en annen måte å vise det på.

Det er altså et grunnpremiss at rommets utforming og innhold $i$ seg selv er av betydning og til teologisk ettertanke. Derfor retter ikke dette kapitlet søkelyset mot bruken av rommet, men mot rommet i seg selv og mot hvilke signaler som er lagt i rommet. Den klare oppmerksomheten på rommet betyr på ingen måte at menighetens erfaring i rommet og med riter og fellesskap er uviktig. Det betyr kun at det ikke er dette vi retter oppmerksomheten mot i akkurat denne undersøkelsen av Tomaskirken. 


\section{Mangfold av estetiske uttrykk i kirkerom}

Den norske kirke har valgt å styrke oppmerksomheten på sanselig tilrettelegging. Å utvikle et mangfoldig sanselig uttrykk i gudstjenesten og i arbeid med kunst og kultur ble satsingsområder fra 2018 (Den norske kirke, 2018). Dette ble særlig begrunnet med kommunikasjon: «Et mangfold av estetiske uttrykk hører hjemme i kirkens rom. Taktil kunst, ordkunst, tegnspråkpoesi og andre visuelle uttrykksformer er eksempler på kunstformer som også kan kommunisere på en særlig måte med mennesker med funksjonsnedsettelser» (Den norske kirke, 2018).

Retningen som i 2018 ble anlagt for videre arbeid, skulle være en forlengelse av Den norske kirkes kulturmelding (2005). Kulturmeldingen var en sammenfatning av kunst- og kulturarbeidet i Den norske kirke og det teologiske grunnlaget for å trekke kunst og kultur inn i kirkene. Da kulturmeldingen ble skrevet, var funksjonshemmingsstudier og -teologi et lite kjent fagfelt i Norge, og dette emnet er ikke behandlet i meldingen. Heller ikke døvekirkene eller tegnspråk som estetisk uttrykk eller teologisk ressurs er nevnt i meldingen.

I stedet for å koble arbeid med mangfoldige estetiske uttrykk og praksis fra teologisk utviklingsarbeid bør de knyttes tett sammen. Et kirkerom som Tomaskirken gir anledning til å diskutere nettopp sammenhengen mellom kirkerom og teologi. Er det for eksempel nok at kunsten er tilgjengelig for alle, og gir dette den tydeligste anerkjennelsen av at alle mennesker er like mye verdt? Eller bør det mangfoldige estetiske uttrykket også vise mennesket som funksjonshemmet og reflektere erfaringen av å leve i samfunn som hemmer og diskriminerer dem med nedsatt funksjonsevne? Diskusjoner knyttet til kunst og funksjonshemming kan bidra til å reflektere rundt disse spørsmålene.

\section{Funksjonshemming og kunst}

I litteraturen om kunst og funksjonshemming differensierer vi ofte mellom «funksjonshemming i kunst» («disability in art») og «funksjonshemmingskunst» («disability art»). Funksjonshemming i kunst refererer til kunst som er laget av eller viser mennesker med 
funksjonsnedsettelser (Sandahl, 2016). Det er mange kjente historiske eksempler på verker av kunstnere som er åpne om sine egne fysiske eller psykiske funksjonsnedsettelser, fra Homer, John Milton og Frida Kahlo til den britiske samtidskunstneren Alison Lapper. Også Marc Quinns Alison Lapper Pregnant (Quinn, 2005), en skulptur som viser Lapper, men som er laget av en kunstner uten (kjente) funksjonsnedsettelser, vil etter denne definisjonen regnes som funksjonshemming i kunst. I Norge er samlingen på Trastad Gård ved Sør-Troms Museum et eksempel på kunst hvor kunstnerne er åpne om at de har nedsatt funksjonsevne.

Derimot brukes funksjonshemmingskunst om ethvert kreativt arbeid som utforsker erfaringer med funksjonsnedsettelse, enten med innhold eller form (Sandahl, 2016). Det er ikke nok at funksjonshemming tematiseres i funksjonshemmingskunst. Kunsten skal vise hva funksjonshemming betyr, personlig, politisk og estetisk. Måten kunsten viser dette på, utfordrer stereotypier og forestillinger om hva som er skjønt, og der kunsten vises, skal det være tilrettelagt slik at mennesker med funksjonsnedsettelser kan delta.

Funksjonshemmingskunst kan være laget av eller vise mennesker med funksjonsnedsettelser. Noen representanter for Disability Arts Movement mener at den må være det, men dette kriteriet er omstridt, det samme er for eksempel spørsmålet om hvorvidt mennesker med funksjonsnedsettelser må være den primære målgruppen for slik kunst (Sutherland, u.å.).

Diskusjonen om funksjonshemming og kunst kan brukes til å spisse spørsmålene om hva et mangfoldig estetisk uttrykk i kirkerommet innebærer. For det første reises spørsmålet om i hvilken grad det er viktig at mennesker med nedsatt funksjonsevne selv skaper kunst og/eller portretteres i kunsten. For det andre påpekes det at kunst kan utforske hva det betyr - estetisk, politisk og personlig - å leve med funksjonsnedsettelse, og derav følger spørsmålet om hvorvidt mangfoldige estetiske uttrykk også skal gjøre det. Annerledes sagt: Er et mangfoldig estetisk uttrykk i kirkerommet et uttrykk som er tilgjengelig også for mennesker med nedsatt funksjonsevne, eller et uttrykk som reflekter livserfaringen deres? 


\section{Del 2: Et kirkerom for sansning}

«Hei. Velkommen til kirken. Vær så snill å ta av skoene», står det på døren til kirkerommet i Tomaskirken. $\AA$ ta av sko seg sine før man trer inn $\mathrm{i}$ et hellig rom er et gammelt ritual, men på dette stedet er det praktiske hensyn som gjør det viktig, for det å trå på gulvet og kjenne vibrasjoner gjennom føttene er en sentral del av dette kirkerommets sanselige opplevelse. I dette rommet er berøring ikke bare noe som skjer via hendene, men med hele kroppen. I tillegg er det flere «sansestasjoner», som jeg kaller de objektene som står langs kanten av rommet, og som har en særlig sanselig, taktil kvalitet. Sansestasjonene appellerer til berøringssansene våre, og her i kirkerommet kan vi undersøke dem taktilt, men også være med på å forme uttrykket.

\section{Et tradisjonelt kirkerom?}

Kirkerommet i Tomaskirken fremstår ved første øyekast som ganske ordinært. Det er et firkantet rom med hvitmalte, glatte vegger, og det fremstår som åpent og lyst. Det er noen få vinduer bak i kirkerommet. I tillegg er det vinduer i taket. Taket er utformet som et lavt tårn, og vinduene står som en lysrekke rundt tårntaket.

Rommet er på mange måter utstyrt som et hvilket som helst annet klassisk luthersk kirkerom. Ved døren står en nøkternt utformet døpefont i tinn på et bord av tre, og midt imot inngangen står alter og prekestol utformet i samme stil. Her finner vi også prosesjonskorset og et stativ for røkelse. Bak alteret henger altertavlen, et gobeleng av tre hengende filleryer. De er i gule og røde toner, fordelt slik at de mørkeste fargene er nederst, og så blir de lysere oppover. Fargekombinasjonen kan minne om lyset i en soloppgang.

Mellom døpefont og alter er det en åpen passasje mellom rekker av enkle stoler i tre. Det er god plass mellom stolrekkene og alteret. Gulvet er et mykt og varmt tregulv som dekker nesten hele den kvadratiske flaten, bortsett fra langs veggene, der det er lagt skiferfliser med nedfelte ledelys. 
Det er mange elementer som gjør rommet godt å bruke for menigheten. For eksempel er lysinntaket utformet for å unngå motlys, siden det brukes mye tegnspråk i rommet, og ledelysene og kontrastene i gulvet gjør at svaksynte lettere kan orientere seg. Det er imidlertid mange kirker som legger opp til dette, så det gjør ikke rommet ekstraordinært. Det er derimot mindre vanlig at musikken reflekteres i gulv og vegger med lys og vibrasjoner.

\section{På skjelvende grunn}

54 store basshøyttalere under gulvet sørger for at lyden fra musikken som spilles i rommet, også blir gjengitt som vibrasjoner i gulvet. I taket over tregulvet er det festet lys som kan blinke med ulike farger og i takt med musikken. Det gjør tregulvet til et sted for intens sansning både gjennom kropp og syn.

Menigheten kan sitte på stolene og kjenne vibrasjonen gjennom føttene, eller de kan sette seg rett på gulvet. Da blir vibrasjonene sterkere. Enda sterkere blir de om man legger seg ned, og alt dette er det plass til. Mellom stolene og alteret fremstår tregulvet som så åpent at det også inviterer til bevegelse eller til å legge seg ned og falle til ro.

Som kontrast til tregulvet virker skifergulvet som omgir det, kaldt og hardt, selv om det har varmekabler. Skifergulvet består av upolerte, mørkegrå fliser og en rad med polerte fliser og nedfelte ledelys som skaper kontrast og retning i steingulvet. Ledelysene inviterer til å gå rundt tregulvet og utforske rommets ytterkant. Denne invitasjonen til bevegelse gjentas i et gelender som fører fra inngangsdøren og rundt veggene i hele rommet. Gelenderet leder til flere objekter som man vanligvis ikke finner i et kirkerom, og flere av objektene har en form eller et materiale som gjør det særlig fristende å berøre dem.

\section{Sansestasjoner}

På pilegrimsvandringen rundt i periferien av kirkerommet er det forskjellige «stasjoner». Fire av dem utmerker seg ved å ha noe spesielt taktilt ved seg. Den første av disse sansestasjonene er til venstre for inngangsdøren. 
Her henger et slags veggteppe laget av hengende tøyremser knyttet til en lang, tynn trestokk. Stoffene har forskjellige mønstre, farger og teksturer og gir ikke noe helhetlig inntrykk. Til mange av remsene er det festet symbolladde objekter. Det er små kosedyr, papirhjerter, nøkler, kors og CD-plater med meditasjonstekster av typen «oppdagelsesreise» og «stillhetsreise». Ved siden av veggteppet står en stor plakat med påskriften «Knytt fellesskap!». Her oppfordres det tilå velge et tøystykke, skrive noe og knytte seg inn i Signos fellesskapsteppe. Det står også at teppet er til Tomaskirken, og kampanjen ser ut til å være fra 2012, året da kirken ble vigslet og «fellesskapets år» i Signo. Teppet på veggen er altså resultatet av kampanjen - et fellesskapsteppe med individuelle stemmer.

Når vi går videre rundt kirkerommet i samme retning som solen, kommer vi etter altertavlen til den andre stasjonen som skal fremheves her. Stasjonen er en kommode i hvitmalt tre. Den er høy, smal og grunn. Åpner vi en av de 14 små skuffene, kan vi finne alle slags mulige ting. Det kan være leker, tusjer, en lysranke eller en klump plastilin, kort sagt det som kirkens besøkende har hatt lyst til å legge igjen.

Ved siden av kommoden står en tredje sansestasjon. Det er en steintavle i svart, kald, hard og polert granitt. På steinen er en inskripsjon som er både frest inn i steinen og malt i koboltblått, slik at den både kan kjennes og sees. Der står det et bibelsitat: «Jesus sier: Den som drikker av det vannet jeg vil gi, skal aldri mer tørste. Joh 4,14». Over inskripsjonen renner det kaldt vann idet man trykker på «vannknappen», en knapp som er godt merket med både bokstaver og punktskrift, og som er ved siden av steintavlen. Fra vannet kommer en sildrende lyd, og det føres bort via en liten renne mellom steintavlen og gulvet.

En fjerde sansestasjon står rett før vi igjen kommer tilbake til inngangsdøren, og den er et bord for lystenning. I bordflaten er det nedfelt et kobberbelagt basseng som er fylt med rødlig, veldig finkornet sand. Sanden inviterer til berøring, og den er silkemyk og glir nesten som vann mellom fingrene på oss når vi løfter den forsiktig opp. Rundt omkring i sanden står det mange telys som er tent eller kan tennes. Sanden gir en sterk sanselig erfaring, men også mulighet for å hente frem egne minner om sand og fortellinger om sand. I noen historier er sanden ørken og fristelse, i andre er den sted der man kan se sine egne livsspor og Guds spor ved siden av hverandre. 


\section{Del 3: Berøringens teologi}

Som vi har sett i gjennomgangen av Tomaskirken og «sansestasjonene» over, skiller Tomaskirken seg i liten grad fra andre kirkerom i norske kirker. Også andre kirker legger opp til vandring rundt $\mathrm{i}$ rommet slik at menigheten kan komme i berøring med ikke bare ordene, men også artefaktene i kirken. Det er først og fremst vibrasjonsgulvet og noen av sansestasjonene som utmerker kirken. Gulvet og sansestasjonene er imidlertid ikke kun for dem med nedsatte sansefunksjoner, men de fungerer for alle. De gjør at Tomaskirken kan gi en mangfoldig sanselig erfaring til alle som besøker den, selv om det er en menighet bestående av mennesker med varierende funksjonsevner.

\section{Å bli tatt i mot}

I Tomaskirken er det lagt opp til at besøkende kan oppsøke og undersøke sansestasjoner med ting som de kjenner fra livet ellers, og som de kanskje har lagt der selv. Hva betyr det at hverdagsobjekter som plastilin og lysranker får plass i kirkerommet? Er det at disse sansestasjonene er i kirkerommet, teologisk betydningsfullt?

Tingene understreker det allmenne uttrykket som preger kirken. Det som er ute i verden, skal få plass i kirken. Skuffene og teppet er steder som viser noe av det som medlemmer i menigheten bærer med seg, og det de legger fra seg. Det mennesker bærer på, kan kirken romme. Derfor kan disse sansestasjonene tolkes som tegn på at hvert enkelt menneske er velkomment akkurat slik han eller hun er, uavhengig av funksjonsevne.

Vi har alle behov for å føle oss velkommen og verdifulle. Det å bli tatt imot som man er, er ikke bare en verdifull livserfaring, men også en viktig del av forkynnelsen. Jesus tar imot oss, Gud tar imot oss. Budskapet i seg selv er viktig, men blir det for enkelt eller naivt? Tomaskirken skal ifølge Signo legge til rette for åndelig erfaring. Er det en åndelig erfaring å få ta med seg tingene sine inn, men putte dem i en skuff? 


\section{Å berøre}

Sansestasjonene fremhever det å berøre som av betydning. Rennende vann og sand er lett tilgjengelig for berøring og ettertanke. Det å berøre blir viktig når det kan skje igjen og igjen gjennom pilegrimsreisen $\mathrm{i}$ rommet. Berøring er et gjennomgangstema i Det nye testamente, som i historien om kvinnen som vil berøre Jesu kappe (Mark 5, 25-34), og historien om disippelen Tomas som berører Jesu oppstandelseslegeme (Joh 20, 24-31). I kunsten repeteres fortellinger om berøring knyttet til Jesu legeme, både før og etter oppstandelsen. I Tomaskirken gjentas ikke disse fortellingene gjennom ord eller bilder, men i form av elementer som mennesket kan kjenne igjen fra hverdagslivet. Kan sansestasjonene forstås som muligheter for berøring av noe hellig, ikke bare noe hverdagslig?

Er for eksempel vannet kilde til åndelig erfaring fordi det er i kirkerommet, eller fordi det er vann, det vil si del av Guds skapelse? På steintavlen der vannet renner, står det som nevnt bibelteksten «Jesus sier: Den som drikker av det vannet jeg vil gi, skal aldri mer tørste» (Joh 4,14). I teksten omtales ikke et hvilket som helst vann, men det vannet som Jesus gir. Er det dette vannet jeg kommer i berøring med i kirken, eller er det med minnet om dette vannet eller minnet om Jesus? Hvilken betydning har det å berøre vannet i kirken?

Sansestasjonene vekker flere spørsmål enn de besvarer. Slik steintavlen og bordet er utformet og knyttet til kristne tekster og ritualer, som lystenning og indirekte også dåp, er flere tolkninger mulig. Det er mulig å se tavlen som et sted der det hellige vannet Jesus snakker om, renner, eller som en tilrettelegging for erfaring av vann som stiller tørsten, noe som igjen gir mulighet til å forstå Jesu budskap om vann som stiller tørsten for bestandig.

Det at berøring får en fremtredende plass i kirkerommet, kan forstås som tegn på at berøring i kirken er verdifullt. Dette er en anerkjennelse av den døves og døvblindes livsvilkår og av det taktile som en mulig kilde til åndelig erfaring, også utenom fellesritualene. Sansestasjonene tematiserer det taktiles betydning for teologien, disippelen Tomas sin fortelling og den døvblindes livserfaring. 


\section{Berørt}

Vibrasjonsgulvet gir en litt annen form for berøring. Vi berører gulvet, og gulvet sender bølger tilbake til oss og gjennom oss. Vibrasjonene berører oss, og sender rytmen gjennom kroppen. Slik blir kirkerommet ikke bare et rom vi kan berøre, men et rom som berører oss. Erfaringen i rommet kan bokstavelig talt være rystende. Vibrasjonsgulvet gir erfaring av at noe kan komme oss i møte og berøre oss. Det blir som et instrument som kan bære budskapet frem, likesom musikken i et orgel kan det.

«Å bli berørt» er en metafor for noe som skjer i relasjoner mellom mennesker, men også mellom mennesker og Gud. I Bibelen hører vi om hvordan Jesus igjen og igjen berører menneskene han møter, i både fysisk og overført betydning. I kristen praksis er sakramentene steder for berøring. Gudstjenesten og andre ritualer kan være slike berøringspunkter, og det samme kan hellige steder og kirker.

\section{Berøringsangst?}

Det er en observasjon at rommet i Tomaskirken ikke inneholder funksjonshemmingskunst, kunst i funksjonshemming eller funksjonshemmingsestetikk. Her finnes det en rekke muligheter som ikke er benyttet i kirkerommet. Deler av inventaret er riktignok laget av mennesker med funksjonsnedsettelser på Signos verksteder, men det kan vi ikke se på gjenstandene. Funksjonshemmingsestetikk er ikke inkludert i gjenstandene. I rommet er det ikke avbildet mennesker med funksjonsnedsettelser, og gjenstandene har heller ingen elementer av disfigurasjon. Med andre ord vil ikke disse artefaktene oppfylle kravene til funksjonshemmingskunst eller kunst i funksjonshemming. Det er heller ikke blitt bestilt utsmykking av de av beboerne som skaper funksjonshemmingskunst.

Fraværet av funksjonshemmingskunst i Tomaskirken er tankevekkende, men er det teologisk sett signifikant? På den ene siden har det allmenne og det allment tilgjengelige en viktig plass i kirkerommet, slik det også har innenfor teologisk estetikk. Å inkludere det som også 
har en allmenn bruk, og som er allment tilgjengelig for alle kirkegjengere uansett funksjonsevne, kan tolkes som en måte å inkludere alle og ikke gjøre forskjell på noen på. Det kan med andre ord være et estetisk uttrykk for at variasjoner av funksjonsevne og -nivå er et grunnleggende vilkår for menneskelivet, og for at alle skal gis tilgang til religiøs erfaring.

På den andre siden kan vi spørre om det ikke hadde vært viktig, teologisk sett, å gi rom for den spesifikke menneskelige erfaringen av nedsatt funksjonsevne, slik funksjonshemmingskunst kan uttrykke den. Tomaskirken er laget som en sansekirke for mennesker med funksjonsnedsettelser, og den kunne derfor på en særlig måte utforsket det taktile på flere måter enn gjennom den allmenne erfaringen. Mangelen på funksjonshemmingskunst i Tomaskirken kan tolkes som at det legges vekt på inkludering, men også som en ubrukt mulighet til å utforske hvordan anerkjennelse av menneskets varierende funksjonsevne kan uttrykkes estetisk gjennom et mangfold av sanselige uttrykk og taktil kunst.

\section{Oppsummering}

Tomaskirken har vært case i denne studien av hvordan mangfoldige estetiske og taktile sanselige uttrykk kan inkluderes i et kirkerom, og hvilken betydning slike uttrykk kan ha for teologien. Hva som menes med «mangfoldige sanselige uttrykk», kan forstås på forskjellige måter, og det kan igjen få konsekvenser for hvilken teologi som reflekteres i de konkrete sanselige uttrykkene.

Bakgrunnen for denne undersøkelsen har vært ønsket om å anerkjenne at variasjoner av funksjonsevne og -nivå er et grunnleggende vilkår for menneskelivet. Denne erkjennelsen gjenspeiles i både Tilvorelsens gave og Den norske kirkes nye satsing på mangfoldige og taktile sanselige uttrykk. Tomaskirken er laget spesielt for mennesker med funksjonsnedsettelser, noe som i seg selv er en slik anerkjennelse.

Undersøkelsen har vist at de sanselige uttrykkene i Tomaskirken er mangfoldige $o g$ taktile i betydningen at de er tilgjengelige for berøring og gir mange sanselige erfaringer. Sansestasjonene er laget også for mennesker med nedsatt hørsels- eller synssans. Det vil si at uttrykkene 
er tilgjengelige for alle mennesker, også dem med nedsatt funksjonsevne. Sansestasjoner som kommoden og veggteppet gjenspeiler en teologi som tar imot og rommer mennesket slik det er, og som gir rom for det mennesket bærer på. Flere av sansestasjonene understreker kirkerommets allmenne preg og fremstår som tilgjengelige og ikke særpreget.

Sansestasjonene vekker mange spørsmål av teologisk karakter. Det de gjør, er altså å tematisere det taktile som betydningsfullt for teologien. Sett i sammenheng får sansestasjonene, inkludert vibrasjonsgulvet, frem perspektivet at menneskets åndelige erfaring handler om både å berøre og å berøres.

Samtidig har undersøkelsen vist at de estetiske uttrykkene i liten grad reflekterer betydningen av funksjonshemming slik det kan tolkes, estetisk, personlig eller politisk, gjennom funksjonshemmingskunst. Denne observasjonen kan ha bakgrunn $\mathrm{i}$ at det historisk sett ikke har vært noen bro mellom arbeid med de estetiske uttrykkene innenfor teologisk estetikk i Den norske kirke og funksjonshemmingsstudier.

Det er behov for videre utforsking av forholdet mellom teologi og taktilitet, og undersøkelsen av Tomaskirken reiser særlig to spørsmål: Hvilken betydning har berøring for teologien, og hva kan en teologi for berøring bety? I Tomaskirken ser vi hvordan sansestasjoner anerkjenner varierte livsvilkår uten å trekke frem en funksjonshemmet livserfaring i seg selv. Skal kirkerommet vise de mangfoldige livsvilkårene vi mennesker lever under, gjennom allment tilgjengelige uttrykk, eller skal de vise mange spesifikke livserfaringer av disfigurasjon og variasjon? Tomaskirken hjelper oss å stille dette spørsmålet fordi mangelen på spesifikke funksjonshemmingsperspektiver i rommet er så åpenbar. I stedet for å være en demonstrasjon av taktil teologi fremstår Tomaskirken som en etterlysning av taktil teologi.

Til slutt er det verdt å bemerke at i undersøkelsen har rommet $i$ seg selv stått sentralt, og resultatene av undersøkelsene sier derfor også kun noe om hvilke perspektiver som gjenspeiles i selve rommet. Dette er interessant ut fra et teologisk-estetisk perspektiv, som vektlegger at rommets utforming og innhold i seg selv er av betydning for teologien. Rommet gir en ramme for den teologien som vises gjennom riter og bruk av rommet. 
Det kan være store spenninger - eller samklang - mellom teologien i selve rommet og i bruken av rommet. Teologisk-estetisk diskusjon av rommet i seg selv gir et godt utgangspunkt for videre empiriske undersøkelser av rommet mens det er i bruk. Det gir også et godt utgangspunkt for normative diskusjoner om hvordan rommet bør utformes og brukes for å gjenspeile både berøringens betydning for teologien - og for berøringens teologi.

\section{Referanser}

Balthasar, H. U. von (1961). Herrlichkeit: Eine theologische Ästhetik. Einsiedeln: Johannes Verlag.

Bergsjø, L. O. (2016). Melankoli og metamorfose. Teologisk-estetisk undersøkelse av Anselm Kiefers verker (Avhandling). Oslo: Det teologiske fakultet, Universitetet i Oslo.

Bruegel, P. (1569). Tiggerne. Maleri. Olje på tre. 0,185 × o,215 meter. Louvre, Paris. Hentet fra https://www.louvre.fr/en/oeuvre-notices/beggars

Bychkow, O. V. (2008). Introduction. I O. V. Bychkow \& J. Fodor (Red.), Theological aesthetics after von Balthasar. Burlington, VT: Ashgate.

Den norske kirke. (2018). Kirkemøtet [Saksdokumenter]. Hentet fra https://kirken. no/nn-NO/om-kirken/slik-styres-kirken/kirkemotet/dokumenter_vedtak/ kirkemotet-11.-16.-april-2018-i-trondheim/

Den norske kirke. (2005). Kunsten å være kirke. Om kirke, kunst og kultur (Kulturmelding). Oslo: Verbum.

Jørgensen, D. (2014). Den skønne toenkning. Veje til erfaringsmetafysik. Religionsfilosofisk udmøntet. Århus: Aarhus Universitetsforlag.

Lid, I. M. (2018). En diakonal praksis tar form. I I. M. Lid (Red.), Diakoni og velferdsstat: Utvikling av en diakonal praksis i samspill med myndigheter, sivilsamfunn og borgere (s. 37-6o). Oslo: Gyldendal Akademisk.

Lid, I. M. \& Bergsjø, L. O. (2018). Kontekstuell teologi. I I. M. Lid (Red.), Diakoni og velferdsstat: Utvikling av en diakonal praksis i samspill med myndigheter, sivilsamfunn og borgere (s. 228-249). Oslo: Gyldendal Akademisk.

Norges Kristne Råd [NKR]. (2017). Tilvorelsens gave. Kalt til å vore kirke av alle og for alle. Norges kristne råds skriftserie, nr. 20.

Quinn, M. (2005). Alison Lapper pregnant. Skulptur. Marmor. 3,5 meter. Hentet fra http://marcquinn.com/artworks/alison-lapper

Sandahl, C. (2016, 3. juni). Disability art. Encyclopaedia Britannica. Hentet fra https://www.britannica.com/art/disability-art\#ref1187356. 
Sandal, M. (2014). Overskridande arkitektur. Ei undersøking av det sakrale i nyare kyrkjebygg. Avhandling. Oslo: Det teologiske fakultet, Universitetet i Oslo.

Siebers, T. (2010). Disability aesthetics. Ann Arbor, MI: University of Michigan Press.

Sutherland, A. (u. å.). What is disability arts? Hentet fra http://www. disabilityartsonline.org.uk/what-is-disability-arts

Redeker, M.-C. (2011). Wahrnehmung und Glaube: Zum Verhältnis von Theologie und Ästhetik in gegenwärtiger Zeit. Berlin: De Gruyter.

Tomaskirken. (u. å.). Tomaskirken. En sansekirke i Signo. Hentet fra http:// tomaskirken.no/

Thiessen, G. E. (2004). Theological aesthetics: A reader. London, England: SCM Press.

Viladesau, R. (2000). Theology and the arts. Encountering God through music, art and rhetoric. New York: Paulist Press. 



\title{
Diakoni i et funksjonshemmingsperspektiv: Tilværelsens gave og Liv i mangfoldig fellesskap
}

\section{Kari Jordheim}

VID vitenskapelige høgskole

\begin{abstract}
In this chapter, the documents The Gift of Being from WCC (2016) and Seeking Conviviality from the Lutheran World Federation (2014) are presented and discussed from a diaconal perspective. Conviviality is described as "the art and practice of living together in solidarity", and the document underlines that this is a learning process. Diakonia is understood as the gospel in action that recognizes and demonstrates the dignity and equality of all human beings. Inclusive communities demonstrate that the contributions of persons living with impairments are valued, that they are respected as participants and co-workers. Conviviality presupposes that all people need to cross borders and overcome their own anxiety when they are confronted with inequalities.

The church should be in the forefront to acknowledge and practice the equality and dignity of all human beings as the central task of living the gospel and give witness of its message in all her work.
\end{abstract}

Keywords: The Gift of Being, Seeking Conviviality, the church of all and for all, diakonia, justice, solidarity

\section{Innledning}

Flere av kapitlene i denne boken trekker frem Tilvorelsens gave fra 2016, et dokument skrevet av Ecumenical Disability Advocates Network (EDAN), et nettverk innenfor Kirkenes Verdensråd (KV). Dokumentet

Sitering av denne artikkelen: Jordheim, K. (2020). Diakoni i et funksjonshemmingsperspektiv: Tilvøerelsens gave og Liv i mangfoldigfellesskap. I I. M. Lid \& A. R. Solevåg (Red.), Religiøst medborgerskap: Funksjonshemming, likeverd og menneskesyn (Kap. 5, s. 107-127). Oslo: Cappelen Damm Akademisk. https:// doi.org/10.23865/noasp.10o.ch5

Lisens: CC BY-NC-ND 4.o. 
handler særlig om mennesker med nedsatt funksjonsevne, men samtidig handler det om alle mennesker. Dette understrekes også av dokumentets undertittel, Kalt til å vere kirke av alle og for alle. Dokumentet er oversatt til norsk og utgitt i Norges Kristne Råds skriftserie (Norges Kristne Råd [NKR], 2017). ${ }^{1}$

I dette kapitlet vil jeg se på hvordan de diakonale fellesskapene utfordres av hovedanliggendet i dette dokumentet, nemlig at «kirken skal være av alle og for alle», i lys av et annet dokument som er publisert i samme periode. Begrepet «conviviality» er blitt introdusert i norsk diakonidebatt de senere årene gjennom et dokument utgitt av Det lutherske verdensforbund i 2014. Den opprinnelige tittelen er Seeking Conviviality: Re-forming Community Diakonia in Europe (Addy, 2014), på norsk oversatt til Liv i mangfoldig fellesskap: Om å fornye diakonien i europeiske lokalsamfunn (Det lutherske verdensforbund [LVF], 2016). ${ }^{2}$

Kirken skal, som et vitnesbyrd om Guds kjærlighet, være et åpent og inkluderende fellesskap hvor alle er likeverdige. Tilvorelsens gave understreker perspektivet fra skapelsesberetningen i 1. Mos 1 om at det å være skapt i Guds bilde slik at vi likner Gud, innebærer at det ikke finnes noen forskjell i den relasjonen Gud, Skaperen, har med det enkelte mennesket. Videre uttrykkes det at i Guds øyne finnes ikke mennesker som er mindre verdt, «uansett hva slags variasjoner som utspiller seg i kropp og sinn» (NKR, 2017, s. 9).

Diakonien er en grunnleggende dimensjon ved kirkens vesen og gir uttrykk for hva det vil si å være kirke (Nordstokke, 2002; Kirkerådet, 2008; LVF, 2010). Diakonien forutsetter og bekrefter det kristne menneskesynet som understreker menneskets enestående verdi ved å være skapt i Guds bilde. Visjonen for Den norske kirkes diakonale tjeneste er «Guds kjærlighet til alle mennesker og alt det skapte, virkeliggjort gjennom liv og tjeneste» (Kirkerådet, 2008, s. 6), en visjon som understreker nettopp det at alle mennesker er innlemmet i Guds kjærlighet

1 Jeg vil referere til den norske oversettelsen av dokumentet og vil derfor bruke referansen NKR, 2017 videre i kapitlet.

2 Jeg vil referere til den norske oversettelsen av dette dokumentet og vil derfor bruke referansen LVF, 2016. 
og er del av fellesskapet i Gud. Selve begrepet «diakoni» brukes på ulike måter, både om personlige oppdrag og om organiserte tiltak, men ifølge Kjell Nordstokke er selve grunnlaget for diakonien tilhørighet til et livsfellesskap (Nordstokke, 2002, s. 14). Nordstokke nevner fotvaskingen i Johannesevangeliet 13 som en tydelig illustrasjon på hva det vil si å være en del av dette fellesskapet. Jesus sier til Peter: «Hvis jeg ikke vasker deg, har vi ikke lenger noe sammen» (Joh 13, 8). Tilhørigheten til fellesskapet er en gave som Herren selv gir, som i neste omgang utfordrer til oppgaver. Den norske kirkes definisjon av diakoni, slik den kommer til uttrykk i Plan for diakoni (Kirkerådet, 2008), understreker dette med formuleringen «Diakoni er kirkens omsorgstjeneste. Den er evangeliet i handling og uttrykkes gjennom nestekjærlighet, inkluderende fellesskap, vern om skaperverket og kamp for rettferdighet» (Kirkerådet, 2008, s. 7). Diakoni beskrives som «evangeliet i handling», og plasseres dermed som en del av kirkens samlede oppdrag. Kirken skal være en tjenende kirke. Planen beskriver videre:

Diakonien er en tjeneste for medmennesket og skaperverket og en tjeneste for Gud.... Alle utfordres til et hverdagsliv i tjeneste. Det gjelder alle aldersgrupper. Diakonien er både en grunntone i alle forhold i menigheten, og den konkretiseres i egne tiltak. Diakonien har et spesielt ansvar der få eller ingen bryr seg. Gjensidighet og respekt for hverandres verdighet er grunnleggende.

(Kirkerådet, 2008, s. 7)

Det er ikke bare innenfor den kristne kirke likeverd og inkludering er viktige verdier. At dette er universelle verdier som skal favne alle, synliggjøres blant annet i bærekraftsmålene som FN har definert. ${ }^{3}$ «Et av hovedprinsippene i bærekraftsmålene fra $\mathrm{FN}$ er at ingen skal utelates (Leaving no one behind)» (De forente nasjoner [FN], 2015). Strømmestiftelsen sier på sine hjemmesider: «Ekskluderte grupper, som mennesker med nedsatt funksjonsevne, flyktninger, etniske og religiøse minoriteter, jenter og urfolk, er høyt representert blant de som fortsatt lever i fattigdom»

3 FNs bærekraftsmål tar over for tusenårsmålene og er verdens felles arbeidsplan for å utrydde fattigdom, bekjempe ulikhet og stoppe klimaendringene innen 2030. 
(Strømmestiftelsen, 2019). Her understrekes utfordringen med å etablere fellesskap som rommer hele det menneskelige mangfoldet.

Likeverd, deltakelse, medinnflytelse og medborgerskap er begreper vi finner innenfor den allmenne samfunnsdebatten, og som det er gitt uttrykk for i sentrale dokumenter, både nasjonalt og internasjonalt og i både kirkelige og sekulære sammenhenger. Begrepene er med på å understreke at det har skjedd et paradigmeskifte i måten man omtaler såkalte marginaliserte grupper på. Slike grupper ble tidligere gjort til objekter for handling, og hjelpearbeidet var preget av paternalisme og veldedighet fremfor rettferdighet. Stephanie Dietrich har skrevet om dette paradigmeskiftet innenfor diakonien i kapitlet «Reflections on core aspects of diaconal theory» i boken Diakonia as Christian Social Practice: An Introduction (Dietrich, 2014), og som et konkret eksempel kan nevnes boken Diakoni og velferdsstat (Lid, 2018), der Inger Marie Lid med flere synliggjør hvordan dette skiftet kommer til uttrykk gjennom den diakonale stiftelsen Signos historie. Det er for enkelt å si at veldedighet og objektivering av hjelpemottakere ikke finnes i dag, men det har uten tvil skjedd store endringer.

I dette kapitlet vil jeg først gi en kort introduksjon av dokumentet Tilvoerelsens gave og den grunnleggende forutsetningen som ligger i forestillingen om alle menneskers likeverd, før jeg går inn i en nærmere introduksjon av dokumentet fra LVF og reflekterer over hvordan begrepet «conviviality» ${ }^{4}$ kan brukes for å vise hvordan diakonien konkret utfordres som brobygger i kampen for inkludering og deltakelse for alle mennesker.

\section{Tilværelsens gave og synet på mennesker med nedsatt funksjonsevne}

Kirkenes Verdensråd ga allerede i 2003 ut dokumentet «En kirke av alle og for alle», som var utarbeidet av Ecumenical Disability Advocates Netword (EDAN). Dette dokumentet handlet om inkludering av mennesker med nedsatt funksjonsevne i kirke og samfunn, og «[m]ed denne

$4 \quad$ Jeg vil bruke det engelske begrepet videre i teksten, selv om jeg for øvrig skriver på norsk. 
utgivelsen tydeliggjorde Kirkenes Verdensråd at de, på linje med en bred global bevegelse, velger et rettighetsbasert innsteg i møte med funksjonshemming» (NKR, 2017, s. 7).

Dette rettighetsperspektivet kommer særlig til uttrykk i FN-konvensjonen om rettighetene til mennesker med nedsatt funksjonsevne (FN, 2013). ${ }^{5}$ Konvensjonens hovedformål er å sikre at mennesker med nedsatt funksjonsevne får like muligheter til å realisere sine menneskerettigheter. Menneskerettighetene og de grunnleggende friheter er allmenne og udelelige, og de skal sikre at alle får mulighet til et selvstendig liv og kan delta fullt på alle livets områder. FN-konvensjonen har et relasjonelt perspektiv på funksjonshemming og fremhever et tydelig skille mellom funksjonsnedsettelse og funksjonshemming, som markerer skillet mellom ødeleggende fysiske og mentale tilstander på den ene siden og sosiale og kulturelle reaksjoner på den andre (NKR, 2017, s. 7). FN-konvensjonen er rettet mot at tilgjengelighet til fysiske, sosiale, økonomiske og kulturelle omgivelser, helse, utdanning, informasjon og kommunikasjon er sentrale elementer for at mennesker med nedsatt funksjonsevne skal bli i stand til å nyte alle menneskerettigheter og grunnleggende friheter fullt ut (FN, 2013).

Funksjonshemming oppstår i et komplekst samspill mellom mennesker og omgivelser, sier Inger Marie Lid (Lid, 2015). Utgangspunktet for en relasjonell forståelse av funksjonshemming er at mennesker er ulike og har ulike funksjonsevner og funksjonsnedsettelser. Funksjonshemming og nedsatt funksjonsevne har alltid tilhørt menneskelivets erfaringer (Lid, 2015). Mens man tidligere har hatt en tendens til å stakkarsliggjøre mennesker med nedsatt funksjonsevne, rettes søkelyset i dag mer mot denne gruppen som medborgere med samme rettigheter som alle andre i samfunnet. Også innenfor kirken og de kristne fellesskapene er mennesker med nedsatt funksjonsevne blitt marginalisert og betraktet som objekter for omsorg. Oppmerksomheten på at alle er skapt av Gud med

5 FNs generalforsamling vedtok FN-konvensjonen om rettighetene til mennesker med nedsatt funksjonsevne 13. desember 2006. Norge undertegnet konvensjonen 30. mars 2007 i henhold til kongelig resolusjon av samme dato. Konvensjonen trådte i kraft 3. mai 2008, da 20 stater hadde ratifisert den. Konvensjonen er utgitt på norsk av Barne-, likestillings- og inkluderingsdepartementet. 
samme verdi og verdighet, og på at alle har noe å dele, utfordrer kirkefellesskapene til å være åpne for mangfoldet blant deltakerne.

I Tilvarelsens gave rettes søkelyset mot at mennesker som lever med funksjonsnedsettelser, og familiene deres, fortsatt marginaliseres, men at det er et klart ønske om å synliggjøre inkludering mer enn ekskludering. Inkluderingsperspektivet kommer tydelig til uttrykk også i språket som brukes. I dokumentet blir det understreket at begrunnelsen for den inkluderende bruken av «vi», «oss» og «vår», er en måte å invitere alle kristne kirker inn for «å lytte til og reflektere rundt erfaringene til mennesker med nedsatt funksjonsevne som lever blant dem. Vi er alle skapt som forgjengelige vesener, og vi lever alle med begrensninger av forskjellige slag» (NKR, 2017, s. 8). Mennesker som selv lever med nedsatt funksjonsevne, har kritisert ordbruken som kategoriserer de funksjonshemmede i en samlet gruppe, og de har skapt slagordet «ingenting om oss uten oss», ${ }^{6}$ som understreker retten til å få presentere sine historier selv, i stedet for at andre skal definere dem og fortelle hva funksjonsnedsettelsene deres betyr.

Dokumentet utfordrer kirkene nasjonalt og internasjonalt til å konsentrere seg om hvordan kirkenes små og store fellesskap skal romme det mangfoldet som finnes representert. Utgangspunktet for dette ligger i synet på menneskelivets verdi, som dokumentet tar opp i første kapittel (NKR, 2017, s. 9-10).

\section{Liv i mangfoldig fellesskap}

Dokumentet med den norske tittelen Liv $i$ mangfoldig fellesskap: om å fornye diakonien i europeiske lokalsamfunn fra Det lutherske verdensforbund (LVF, 2016), ble skrevet ut fra behovet for å reflektere kritisk over diakonibegrepet i en tid preget av økt individualisme og fragmentering, hvor livet i fellesskap må bekreftes. Et sentralt begrep i dokumentet er det engelske «conviviality» (oversatt til «liv i mangfoldig fellesskap»), som forklares slik:

6 The Disability Rights Movement: «Nothing about us without us». 
Det betyr, kort forklart, «kunsten og erfaringen med å leve sammen». Det kommer fra det spanske ordet «convivencia» og omfatter det å leve sammen i solidaritet, med delte ressurser og i en felles kamp for menneskeverd og bærekraftige lokalsamfunn. Det har klangbunn i gamle tradisjoner der nabolag sammen opprettholder et felles liv, og i tradisjonene til migrantfellesskap som nører opp om liv i nye omstendigheter som noen ganger ikke er så åpne som en skulle håpe og tro. (LVF, 2016, s. 4)

Det er ikke spesifikt mennesker med nedsatt funksjonsevne som utgjør bakgrunnen for at conviviality er så sentralt, men oppmerksomheten på hvordan mennesker skal leve sammen i fellesskap er et hovedanliggende i dokumentet. Usynliggjøring av mennesker blir beskrevet som en stor utfordring i Europa i dag, med særlig oppmerksomhet på mennesker hvis behov er skjult ved at de ikke kvalifiserer til ett eller flere av de tilbudene man normalt forutsetter at velferdsstaten skal ta ansvar for. Migranter i randsonen nevnes spesielt som en slik gruppe, men også andre grupper møter diskriminering og kan ha vanskeligheter med å få tilgang til de tilbudene de trenger. Blant disse nevnes mennesker med nedsatt funksjonsevne som en marginalisert gruppe som kan oppleve at de ekskluderes fra vanlige tilbud på grunn av manglende kapasitet eller ressurser (LVF, 2016). Mange lokalsamfunn og lokalmenigheter opplever å bli utfordret av forskjellighet for første gang ved at migranter kommer flyttende og representerer nye kulturer, erfaringer og holdninger. Mennesker med nedsatt funksjonsevne bor og lever ofte i lokalmiljøene allerede, men representerer et mangfold som mange lokalmenigheter ikke har tatt på alvor og lagt til rette for. I møte med mangfoldet har mange lokalmenigheter forblitt passive og tillukket.

Tony Addy, som er en av hovedforfatterne bak Liv i mangfoldig fellesskap har skrevet om conviviality i flere sammenhenger (Addy, 2014, 2017, 2019). Han er opptatt av at dette er et begrep som ikke avgrenses som et diakonalt prosjekt, men som er i utvikling og kan kaste lys over diakonibegrepet i både menighets- og organisasjonssammenhenger (Addy, 2019). Selve begrepet er ikke nytt, og en av tradisjonene går tilbake til den katolske presten Ivan Illich (opprinnelig fra Kroatia) som arbeidet i Latin-Amerika og senere i de fattigste boligområdene i New York. I 1973 
ga han ut boken Tools for Conviviality (Illich, 1973), der han understreket conviviality som en selvstendig og kreativ kommunikasjon mellom mennesker og mellom mennesker og deres omgivelser. Han betraktet det å leve sammen i mangfoldig fellesskap som å leve i frihet med gjensidig ansvar for hverandre (Illich, 1973). I arbeidet med heftet fra LVF var det en arbeidsgruppe, kalt Solidaritetsgruppen, som ønsket å arbeide videre med dette begrepet, og de beskrev conviviality som «the art and practice of living together in solidarity» (Addy, 2014). Kunsten å leve sammen er blitt ytterligere utfordret $\mathrm{i}$ vår tid, med økende forskjeller mellom mennesker som skal leve sammen i små og større fellesskap. I dokumentet fra LVF er det de økende forskjellene i Europa som får særlig oppmerksomhet, nevnt under følgende fire overskrifter (Addy, 2014):

- Finanskrise - sosial krise - politisk krise

- Unge og gamle betaler prisen

- Tvunget til å flytte - tvunget til å bli

- Usynlige mennesker og marginaliserte grupper

Dokumentet er særlig opptatt av hvordan inkluderende fellesskap på forskjellige nivåer kan bygges. Målet er å øke bevisstheten hos mennesker i ulike kirkelige kontekster når det gjelder spørsmålsstillinger knyttet til diakoni i lokalsamfunn og politisk påvirkningsarbeid, og å gjøre dem bedre i stand til å gå inn i disse spørsmålsstillingene.

I lys av endringer og økende ulikhet i europeiske samfunn, holder rapporten fram en visjon om diakoni i europeiske lokalsamfunn som skaper rom for å bygge tillit og leve sammen i mangfoldige lokalsamfunn, med engasjement for solidaritet og rettferdighet. ... Den gir stemme til mennesker som tvinges til å leve i samfunnets randsoner. Disse menneskene blir til ledende aktører i prosessen med å analysere deres situasjon og finne langsiktige løsninger. Den stiller spørsmål ved «giver og mottaker» bildet, både som en måte å tjene dem som trenger det på, og som en måte å dele ressurser mellom kirkene. Visjonen om diakoni utvikles derfor i lys av en kontekst og søker å myndiggjøre mennesker til å ta ansvar for deres eget lokalsamfunns endringsprosess, og å leve og skape nye livshistorier som aktive deltakere i et fellesskap. Denne rapporten bekrefter kirkens kall til diakoni: fra Gud og fra vår neste. (LVF, 2016, s. 2) 
Mye forskning viser at mennesker tradisjonelt søker sammen med andre som likner seg selv. Liv i mangfoldig fellesskap tar denne tankegangen på alvor, og sier at det kreves en bevisst ny læringsprosess for å kunne bryte ned de grensene som er blitt bygd opp mellom mennesker som tilhører ulike grupper. Man utfordrer tankegangen om at mennesker er for forskjellige til å kunne leve sammen, ut fra tanken om at mennesker fra skapelsen av er kalt til å leve sammen i mangfoldige fellesskap. Derfor vil det å leve sammen og gjøre ting sammen være å bekrefte Guds skapertanke. Ofte kan dette bety at man må bevege seg utenfor sin egen komfortsone. Erfaringer viser også at ved å leve side om side skjer det noe. Madeleine Buntling forteller i en artikkel i The Guardian om et interessant forskningsarbeid ledet av et team med sosialpsykologer ved Universitetet Oxford. Forskningen ble gjennomført i USA, Europa og Sør-Afrika over en tiårs periode, hvor funnene helt klart understreker at når mennesker lever sammen og angår hverandre i hverdagen vil selv svært fordomsfulle mennesker vise en større grad av toleranse over tid, mens de som ikke lever i tilsvarende lokalsamfunn, heller ikke utvikler denne toleransen (Buntling, 2014).

Conviviality er å leve sammen i solidaritet. I boken The Diaconal Church skriver Addy i et kapittel kalt «Seeking conviviality: a new core concept for the diaconal church» (Addy, 2019, s. 158-170) om hvordan solidaritet bringer et viktig perspektiv inn i det å leve sammen i mangfoldige fellesskap. Solidaritet betyr å dele og gi opp noe av sitt eget. Solidaritet betyr gjensidige forsøk på å skape et felles liv sammen og på å skape en bedre verden. Dette krever at hver enkelt trenger å bli kjent med seg selv og sine egne motiver og håp (Addy, 2019).

\section{Solidaritet og gjestfrihet}

Solidaritet er et begrep som gir gjenklang i diakonien. Det er også et annet begrep som ofte blir henvist til, nemlig hospitalitet eller gjestfrihet. Gjestfrihet har sterke røtter i den kristne tradisjonen, og som Nordstokke skriver i boken Det dyrebare mennesket, har det helt fra kirkens første tid vært en hovedakse i den diakonale praksisen (2002). Aksens ene tyngdepunkt er visitasjonen, den oppsøkende tjenesten for å være 
nær den sårbare og utstøtte. Det andre tyngdepunktet er gjestfriheten, som innebærer en åpenhet for å ta imot og inkludere mennesker i fellesskapet (Nordstokke, 2002, s. 66). I lys av begrepet conviviality kan det synes som om dette begrepet går lenger i tanken om fellesskapet. Hospitalitet - gjestfrihet - dreier seg om å ta imot en fremmed, en som kommer utenfra, men det ligger i begrepet at det er en fremmed, en som vi skal ta oss av, og som ikke direkte er deltaker i fellesskapet. Kanskje kan gjestfriheten være et skritt på veien til conviviality, for i dette begrepet ligger et mer langsiktig tidsperspektiv, siden det ikke bare dreier seg om å være gjest i en periode, men om å leve sammen? I en gjest-vert-relasjon har verten ofte en ansvarsrolle med å ta seg av gjesten, og naturligvis kan det være noe å lære for både gjest og vert i en slik situasjon. Men dersom man skal leve sammen, utfordres man på en annen måte av gjensidighet, det vil si å finne ut hvordan man skal forstå hverandres ulikheter, og hvordan den enkeltes ressurser kan komme til uttrykk i fellesskapet. $\AA$ leve sammen i fellesskap forutsetter at man er nødt til å krysse grenser og lære seg å overkomme redsel og usikkerhet i møte med forskjeller og annerledeshet. Dette forutsetter tillit og dialog.

Dialog kan defineres som «et møte ansikt til ansikt mellom likeverdige parter, uten skjulte hensikter. Jeg går inn i en dialog, ikke for å forandre den andre, men for å ta del i den gjensidige forandringen som kan skje gjennom et møte» (Grung, 2011, s. 561). Det å være åpen for at møtet med den andre også kan skape forandring for egen del, er en forutsetning for å kunne leve sammen i mangfoldig fellesskap. Respekten for den andre og det den andre bringer med seg, ligger under som en grunnholdning, men den gjensidigheten fellesskapet søker, kan kreve endring fra begge parter.

Blant Guds skapninger er det stort mangfold. Mangfoldet består av ulikheter i både ressurser og begrensninger, hvilket er et uttrykk for at alle mennesker er forskjellige og må ses på som unike. Funksjonshemmede må heller ikke betraktes og omtales som en enhetlig gruppe, for mennesker med funksjonsnedsettelser er like forskjellige fra hverandre som mennesker i resten av samfunnet. Tilvorelsens gave retter søkelyset mot at livet er Guds gave, og at Guds formål for jordens skapninger ikke avhenger av kapasiteten eller evnene deres (NKR, 2017, s. 10). 
Nordstokke nevner tre elementer i det kristne menneskesynet som er sentrale ut fra diakonal tenkning og praksis i et fellesskap av alle og for alle (2002). Det første er at mennesket er skapt til relasjoner. Gjennom hele livet er mennesket henvist til andre mennesker med god vilje og omsorg. Det andre er at mennesket er skapt til mangfold, og mangfoldet vitner om Guds skaperevne og rikdom. Det er ingen grunn til å gradere mennesker etter rase, kjønn, sosial tilhørighet, funksjonsevne eller andre sorteringskriterier. Det tredje elementet er knyttet til at mennesket er skapt til oppdrag. Enhver er utrustet med kvaliteter og evner, og oppdraget den enkelte har fått, skal utføres på ulike måter og ut fra ulike forutsetninger. Nordstokke hevder at det gode livet vokser frem som frukt av disse tre elementene (Nordstokke, 2002, s. 24). Det diakonale fellesskapet bygger på dette menneskesynet som anerkjenner ethvert menneskes verdighet med den enkeltes unike gaver og evner. Samtidig understrekes relasjonene man står i. Alle mennesker er kalt til fellesskap.

\section{Inkluderende fellesskap eller conviviality?}

Harald Hegstad skriver i boken Den virkelige kirke. Bidrag til ekklesiologien om forholdet mellom den enkelte og fellesskapet, og han hevder at kirken må skape et balansert forhold mellom medlemmenes behov for individualitet og sosialitet. Det kollektive og det individuelle utfyller hverandre, og kirken må under ingen omstendigheter krenke enkeltmenneskers integritet og rettigheter. Derfor er det av stor betydning at man retter søkelyset mot fellesskapet som grunnleggende for den kristne kirke (Hegstad, 2009).

I planen for diakoni blir inkluderende fellesskap beskrevet som et uttrykk for «evangeliet i handling» og for kirkens medmenneskelige omsorg. I et inkluderende fellesskap skal den enkelte både se og bli sett. «Der gis gjensidig trøst og hjelp, der frigjøres nye krefter og nytt håp», står det i diakoniplanen (Kirkerådet, 2008, s. 10).

Omvendt kan man si at en kirke uten inkluderende fellesskap ikke er en «hel» kirke. Et fellesskap hvor mennesker med nedsatt funksjonsevne blir holdt utenfor, blir selv et fellesskap med nedsatt funksjonsevne. Men 
hva betyr det at et fellesskap er inkluderende? Stephanie Dietrich problematiserer dette i et kapittel i boken Kirke nå, der hun reflekterer over kirken som inkluderende fellesskap: «[H]vem er da kirken, hvis noen inkluderer og andre blir inkludert?» (Dietrich, 2011, s. 51). Dette spørsmålet innbefatter at noen «innenfor» fellesskapet er subjekter som gjør noen andre «utenfor» fellesskapet til objekter. Hvem er de som inkluderer? Er det de som er aktive i menigheten, eller de ansatte? Er det medlemmer av kirken som er innenfor, mens ikke-medlemmer står utenfor? Eller krever det å være inkludert eller å bli inkludert noe annet - at man tilpasser seg formene i kirken, oppfører seg slik det er akseptabelt, ikke skiller seg ut på noen måte? Dietrich konstaterer at begrepet inkludering lett kan få en paternalistisk undertone, og hun foreslår derfor at «inkluderende» erstattes med «åpen» for å synliggjøre at kirkens fellesskap bygger på gjensidighet og likeverd og representerer et åpent rom der alle er velkomne (s. 55).

Dietrich berører her det tradisjonelle skillet som i stor grad også har preget diakonien gjennom historien. Diakoniens utøvere har opptrådt som subjekter som har handlet overfor «noen», som dermed blir objekter. Denne objektiveringen av mennesker er en trussel mot verdigheten og gjensidigheten. I arbeidet med plandokumentet for diakoni fra 2008 var dette sentralt, siden det første plandokumentet fra 1988 ga mer uttrykk for den tradisjonelle subjekt-objekt-tenkningen (Jordheim, 2009).

Den kubanske teologen Carlos Ham har skrevet om hvordan man i den økumeniske bevegelsen har observert tre ulike faser eller modeller når det gjelder diakoniens utvikling, som han kaller «the charity, the reciprocity and the transformative models» (Ham, 2014). På norsk kan dette oversettes med «veldedighet, gjensidighet og forvandling».

Den første modellen samsvarer med det som er nevnt ovenfor, om en «ovenfra-og-ned», objektiverende modell. Veldedighetsmodellen strekker seg frem til begynnelsen av 1980-tallet, ifølge Ham. Gjensidighetsmodellen tilskriver han til perioden fra 1980-årene, hvor man opplever at stemmer fra Sør og fra grasrota kommer mer på banen, og man begynner å se myndiggjøring i praksis innenfor diakonien. Man snakker mer om gjensidig tillit og deltakelse. Likevel ser man ifølge Ham en god del «vi og dem»-tenkning også i denne perioden, men oppmerksomheten på 
menneskelige ressurser kommer mer frem, og det legges klare føringer for endring. Ham mener at det skjer en radikal endring rundt 2012, da det avholdes en stor økumenisk konferanse i regi av Kirkenes Verdensråd i Colombo på Sri Lanka, med temaet «Theological Perspectives on Diakonia in the Twenty-First Century». Han beskriver at det på denne konferansen ble tydeligere oppmerksomhet på den diakonale praksis, særlig fra dem som ofte ekskluderes i både samfunn og kirke. Dette utløste i neste omgang et arbeid for å inkludere og integrere de marginaliserte, de som ofte befinner seg i periferien, som funksjonshemmede, urbefolkning og fattige, og han beskriver prosessen som «empowered to change society in a bottom-up approach, in an inductive manner, the effect of this model is transformation» (Ham, 2014, s. 109-110).

Ham er tydelig opptatt av at «empowerment» (på norsk ofte oversatt til «myndiggjøring») er avgjørende for diakonien, og han ser på dette på følgende måte:

... en dynamisk prosess som muliggjør og inspirerer, som forbedrer menneskers ferdigheter og selvtillit; det er en bevegelse som frigjør mennesker til å ta tilbake og utvikle sine egne krefter, til å forløse det enorme potensialet deres og for å $ø$ ke ferdighetene, selvtilliten og selvbekreftelsen. Denne prosessen tar sikte på å fremme kollektiv motstand, utfordring og mobilisering mot grunnleggende maktrelasjoner og systemiske krefter som utarmer og utelukker de sårbare. Det er en utvikling fram mot positiv endring i livssituasjonen for mennesker ved å skape rettferdighet, inkludering og deltakelse mot transformasjon og livets fylde. (Ham, 2014, s. 111, min oversettelse)

Myndiggjøring er et begrep som står sentralt i diakonien, nettopp fordi det vektlegger gjensidighet, endring av maktstrukturer og et ønske om å oppmuntre mennesker til å ta ansvar i egne liv og bli subjekter. På den måten er myndiggjøring et kraftig motstykke til det å motta veldedighet og å være et objekt.

Deltakelse må også være et kjennetegn ved fellesskap som skal kunne inkludere mangfoldet. Det skal være mulig for alle å være i både en giverposisjon og en mottakerposisjon - kanskje til og med samtidig. Den enkelte skal få være den han eller hun er, og bidra på sine egne premisser 
med de ressursene han eller hun har. Her er det ikke bare snakk om gjestfrihet og vennlighet, men om rettigheter. Alle skal ha like muligheter for å være deltakere, og så kan man videre spørre hva det betyr i den konkrete situasjonen. Diakonien søker å myndiggjøre mennesker til å ta ansvar for egne og fellesskapets endringsprosesser og til å leve og skape nye livshistorier som aktive deltakere i et fellesskap. Den diakonale utfordringen er å finne ut hvem den enkelte er, hva han eller hun ønsker å bidra med i fellesskapet, og å anerkjenne dette og legge til rette for deltakelsen. Bibelen beskriver fellesskapet som én kropp med mange ulike lemmer og funksjoner (1. Kor 12). Å være én kropp kommer best til uttrykk i fellesskap der mennesker deler livet med hverandre.

I plandokumentet for diakoni står det også eksplisitt at det må arbeides systematisk med å legge forholdene til rette slik at mennesker med funksjonshemninger kan delta på lik linje med andre (Kirkerådet, 2008). De fleste fellesskap har ressurser som ikke blir tatt i bruk fordi man tenker for tradisjonelt om hva som trengs, eller fordi man rett og slett ikke oppdager de ressursene enkeltpersoner besitter.

Den kristne kirkes historie har mange eksempler på at noen er blitt oppfattet som mennesker med høyere rang enn andre. De rike kunne kjøpe seg fordeler, mennesker med funksjonshemminger ble ikke konfirmert fordi de ikke kunne uttrykke kunnskap om troslæren godt nok, og så videre. I Tilvarelsens gave henviser man også til den tiden da nedsatt funksjonsevne ble omtalt som en straff i teologiske tekster og kirkelige dokumenter (NKR, 2017, s. 7). Fortsatt i dag finner man menneskesyn og holdninger innenfor kirken som rangerer mennesker ut fra ulike verdiskalaer - særlig yteevne og utrustning - og det er fortsatt lang vei å gå for at fellesskap skal være åpne for alles deltakelse.

Det er interessant å sammenlikne mennesker med nedsatt funksjonsevne med andre grupper i samfunnet som kan oppleve seg marginalisert. I et notat fra Norsk institutt for forskning om oppvekst, velferd og aldring (NOVA) fra 2011 er det satt søkelys på modeller for å sikre medbestemmelse og medinnflytelse blant utsatte ungdomsgrupper. Forfatterne har gjort et stort arbeid for å skaffe seg oversikt over hva som blir gjort, både nasjonalt og internasjonalt, og de konkluderer med at det å sikre deltakelse ofte krever omfattende ressurser og tilrettelegging (Winslow \& Falck, 2011). 
Ikke minst kontinuitet, stabilitet og gode personlige relasjoner blir framhevet som viktige hjørnesteiner om de unge skal ha mulighet til innflytelse og medvirkning. Oppsøkende arbeid er ofte avgjørende for å nå målgruppen. Dessuten er det et behov for samarbeid på tvers mellom ulike etater og organisasjoner. For å fremme utsatte unges medinnflytelse og styrke deres rett til å bli hørt, må det legges til rette for at deltakelse skal kunne finne sted på flere ulike arenaer. ... Hverdagsinnflytelse betyr mye for utsatte grupper, større muligheter til å påvirke sin egen fremtid gir også en økt mestringsfølelse. (Winslow \& Falck, 2011, s. 8)

Dette synes å være sentrale perspektiver også for å sikre deltakelsen til mennesker med nedsatt funksjonsevne. Kirken bør ta ansvar som en aktuell og viktig aktør. Samarbeid mellom ulike arenaer synes å være en viktig faktor for at samfunnet som helhet skal bli mer inkluderende.

I den samme rapporten presenteres ulike modeller for deltakelse, og det henvises til en modell av oppvekstforskeren Harry Shier som skiller ut fem kategorier av deltakelse i en type nivågradering. Modellen er utviklet i møte med barn og unge, men synes som en modell som kan være nyttig også i møte med andre grupper som opplever seg marginalisert. Shier beskriver kategoriene slik (Shier, 2001, s. 107-117):

- å bli lyttet til,

- $\quad$ å få hjelp til å uttrykke sine synspunkt,

- $\quad$ synspunktene blir tatt hensyn til,

- å trekkes inn i pågående beslutningsprosesser,

- å dele makt ogansvar for de beslutningene som tas.

Innenfor offentlige tjenestetilbud snakker man om brukermedvirkning. I diakonale sammenhenger, som vi her konsentrerer oss om, finnes det også brukere av tjenester samtidig som det anses som viktig at alle skal kunne være deltakere og medarbeidere i fellesskapet. Det vil alltid være slik at man noen ganger har behov for å være mottaker og bruker, og andre ganger er i en situasjon hvor man kan være bidragsyter. Mennesker befinner seg i ulike situasjoner gjennom livet, og ofte kan man være både giver og mottaker samtidig. Dette gjelder ikke bare for mennesker med funksjonsnedsettelser, for livets utfordringer når alle gjennom sykdom, alderdom, arbeidsledighet og andre endringer i livet. Alle vil oppleve 
at man i perioder trenger å motta mer støtte og omsorg fra fellesskapet enn man selv er i stand til å gi. Derfor er det viktig å arbeide aktivt med modeller som kan bidra til å åpne opp for aktiv deltakelse fra alle grupper, men også å gi rom for at det oppleves greit å være mottaker.

\section{Diakonale utfordringer}

Diakoni er et kall - å bringe Guds kjærlighet til alle mennesker og alt det skapte, virkeliggjort gjennom liv og tjeneste - slik det står i visjonen for Plan for diakoni i Den norske kirke. Diakoni er en måte å leve på som fremmer likeverd og rettferdighet mellom mennesker. Dette livet må læres og utvikles, og i denne sammenhengen er lokalmenigheten en viktig og sentral faktor. Som det står i Liv i mangfoldig fellesskap:

I en inkluderende, åpen og støttende menighet vil kallet til diakoni lettere fostres hos medlemmene fordi det vil virke naturlig og ikke som et særskilt fagområde. Det kan hende at et diakonalt kall er noe som blir fanget opp, heller enn at det læres ("caught not taught"), for å bruke et engelsk uttrykk, når mennesker er del av et støttende, oppmuntrende miljø. Denne effekten kan forsterkes ved å sørge for at alle deler av kirkens virke, som for eksempel konfirmantopplæring, legger vekt på diakoni og det å ta del i kristne, sosiale handlinger i praksis. Spesielt tilrettelagte programmer kan utvikles på lokalplan for å fremme et diakonalt kall blant unge mennesker. Disse kan videreføres gjennom initiativ som et «diakonalt år» med tjeneste et annet sted i landet eller i utlandet. Men slike initiativ må bygge på en lokal diakonal kultur, for å kunne bli noe som integreres i hele livet, og ikke bare et valg knyttet til én viss fase. (LVF, 2016, s. 28)

Diakonien er av mange beskrevet som en virksomhet som bygger broer mellom kirken og arenaer utenfor (Collins, 1990; Nordstokke, 2009; Jordheim, 2014). Å være brobygger i en diakonal forståelse av ordet er å bringe historiene fra de marginaliserte og utsatte inn i kirken, men også at kirken går ut på ulike arenaer i samfunnet der hverdagslivet leves, og der de politiske beslutningene blir tatt. I Plan for diakoni står det uttalt at det å kjempe for rettferdighet også dreier seg om å engasjere seg i samfunnsdebatten lokalt når vi ser at menneskeverdet blir krenket. 
Mennesket lever i og er avhengig av samfunnsmessige strukturer. Verdensomspennende systemer er med på å bestemme den enkeltes liv. Det er derfor nødvendig å klargjøre årsakene til menneskelig nød og lidelse, arbeide for å endre forhold som opprettholder nødstilstander og skape nye livsmuligheter. Å vise solidaritet er å ta opp kampen og arbeide for rettferdighet og fred. (Kirkerådet, 2008, s. 10)

Det er en viktig oppgave for diakonien å ha fokus på hvor urettferdighet, utnytting og undertrykking skjer. I Liv i mangfoldigfellesskap (LVF, 2016, s. 21) understrekes det at diakoniens oppmerksomhet på rettferdighet må følge tre hovedlinjer:

- Sette søkelyset på prioriteringen av mennesker som er marginalisert, eller som på en eller annen måte er underpriviligert.

- Gjøre alle til deltakere i samfunnet og bidra til at alle kan delta i institusjoner og prosesser som preger deres hverdagsliv. Det er dette de demokratiske prinsippene dreier seg om.

- Engasjere seg i påvirkningsarbeid overfor økonomiske og politiske myndigheter slik at det ikke etableres strukturer som holder mennesker nede.

Det er stort samsvar mellom disse hovedlinjene og det som presenteres i Tilverelsens gave, hvor prinsippene om prioriteringer, likeverd, mangfold, deltakelse, samhandling og myndiggjøring er fremtredende. Det understrekes at kirken har et særlig ansvar for å etablere felleskap hvor bidragene fra mennesker som lever med funksjonsnedsettelser, settes pris på og inkluderes, for «kirken skal være av alle og for alle». Samtidig er det i dokumentet også en klar bevissthet om at det er kontekstavhengig hvordan støtte best kan gis.

Sosioøkonomiske og kulturelle forskjeller kan prege vurderingene av hva samfunnet rundt skal stille opp med. Når det gjelder kirken, kan det imidlertid være liten tvil om dens kall, som er å være fellesskap med dets medlemmer med nedsatt funksjonsevne, i erkjennelse av gaven hvert medlem har å komme med. (NKR, 2017, s. 11) 
Men det rettes også oppmerksomhet på at når støtte gis ut fra kategoriske oppfatninger av behov, kan det føre til atskillelse. Det må alltid stilles kritiske spørsmål til ekskludering og segregering, og kirken må gå foran i det å skape rom for mangfoldet for hver og en av medlemmene sine. Det forutsetter at man alltid har øynene åpne for individuelle behov, og at det må skapes rom for den enkelte (NKR, 2017, s. 11).

Diakonien skal ha et særlig ansvar overfor mennesker i sårbare og utsatte livssituasjoner. Men det er ikke bare et spørsmål om å vise godhet og nestekjærlighet. Den strukturelle og institusjonelle siden er avgjørende, og derfor må kirkens diakonale aktører heve stemmen og engasjementet i forhold til bestemmende myndigheter når det er snakk om rettigheter og mulighet for deltakelse.

De som kjemper for rettighetene sine er ofte ikke komfortable med veldedighet, hverken i kirkelig eller annen regi. De ønsker å bli verdsatt for det de har å bidra med, heller enn å tas imot som mennesker i nød som skaper muligheter for andre til å praktisere sin kristne plikt. (NKR, 2017, s. 20)

\section{Oppsummering}

Tilvorelsenes gave er skrevet i et inkluderende språk for å understreke at kirken er et felleskap som består av alle - uavhengig av funksjonsgrad. Sammen skal vi lytte til erfaringene til de menneskene med nedsatt funksjonsevne som er en del av kirken, og vi skal snakke om hvordan vi kan leve godt sammen i mangfoldige fellesskap. Kirken snakker om inkluderende fellesskap som et sentralt uttrykk for en diakonal kirke. Kanskje skal vi heller snakke om mangfoldige fellesskap. Dette markerer i tydeligere grad at vi sammen må skape fellesskapene vi skal leve i. Rapporten Liv $i$ mangfoldig fellesskap utfordrer til en radikal nytenkning om diakoni. Dr. Musa Panti Filibus, direktør for LVFs avdeling for misjon og utvikling, sier i forordet til dokumentet:

Den gir stemme til mennesker som tvinges til å leve i samfunnets randsoner.

Disse menneskene blir til ledende aktører i prosessen med å analysere deres situasjon og finne langsiktige løsninger. Den stiller spørsmål ved «giver og mottaker» bildet, både som en måte å tjene dem som trenger det på, og som en 
måte å dele ressurser mellom kirkene.... Denne rapporten bekrefter kirkens kall til diakoni: fra Gud og fra vår neste. Den inviterer kirkene til å tenke om igjen om sine diakonale metoder på en slik måte at de utfordrer strukturell ulikhet og urettferdighet. Den oppmuntrer oss til å arbeide for langsiktig endring mens vi holder fast på viktigheten av å svare på prekære, grunnleggende behov hos mennesker og lokalsamfunn. Diakoni må være forankret på grasrota, der hvor effekten av sosiale, politiske og religiøse saker kjennes best og forstås best. (Addy, 2014, s. 2)

Det er dette som er å leve ut evangeliet i handling.

Når mennesker med funksjonsnedsettelser opplever store mangler i livsstandard sammenliknet med andre medlemmer i samfunnet, er det urettferdig. Fattigdom og mangel på muligheter kan være enda større i land i sør enn her i nord, men det er likevel store ulikheter i vårt eget samfunn som utfordrer kirken til solidaritet og kamp for mer rettferdige forhold. Dette dreier seg om menneskesyn, likeverd og rettferdighet.

Diakonien må utfordres av at alle mennesker har rett til å leve et menneskeverdig liv: «Vi kan ikke stille oss likegyldige til mennesker som kjemper for livet. I denne kampen må vi stå på rettferdighetens og solidaritetens side sammen» (Kirkerådet 2008, s. 23).

$\mathrm{Vi}$ vet at kirken både lokalt og globalt fortsatt har lang vei å gå før den kan hevde å være «kirke av alle og for alle - en kirke hvor bidragene fra mennesker som lever med funksjonsnedsettelser, settes pris på, hvor de respekteres for den de er og finner støtte i fellesskapet» (NKR, 2017, s. 24). Men kirken må gå foran i å «anerkjenne og praktisere alle menneskers likeverd og verdighet, i tråd med oppdraget om å leve ut evangeliet, og om å vitne om dets budskap i alt den gjør» (s. 24). Kirken må aktivt praktisere at livet skal leves i mangfoldige fellesskap.

\section{Referanser}

Addy, T. (2014). Seeking conviviality. Re-forming community diakonia in Europe.

Genève: Lutheran World Federation.

Addy, T. (2017). Seeking conviviality. Re-forming community daikonia in Europe.

Evaluation and commentary from the European solidarity group. Genève: Lutheran World Federation. 
Addy, T. (2019). Seeking conviviality: A new core concept for the diaconal church. I S. Dietrich, K. Jørgensen, K. K. Korslien \& K. Nordstokke (Red.), The diaconal church. Oxford, England: Regnum Books International.

Bunting, M. (2014, 16. Mars). If you don't think multiculturalism is working, look at your street corner. The Guardian.

Collins, J. N. (1990). Diakonia. Re-interpreting the ancient sources. New York: Oxford University Press.

De forente nasjoner (FN). (2013). FNs konvensjon om rettighetene til mennesker med nedsatt funksjonsevne. Oslo: Barne-, likestillings- og inkluderingsdepartementet. Hentet 24.10.18 fra https://www.regjeringen.no/ globalassets/upload/bld/sla/funk/konvensjon_web.pdf

De forente nasjoner (FN). (2015). FNs bærekraftsmål. Hentet 24.10.18 fra https:// www.fn.no/Om-FN/FNs-baerekraftsmaal

Det lutherske verdensforbund [LVF]. (2010). Diakoni i kontekst. Genève: Det lutherske verdensforbund.

Det lutherske verdensforbund [LVF]. (2016). Liv i mangfoldig fellesskap. Om å fornye diakonien i europeiske lokalsamfunn. Genève: Det lutherske verdensforbund.

Dietrich, S., Dokka, T. S. \& Hegstad, H. (Red.) (2011). Kirke nå. Den norske kirke som evangelisk-luthersk kirke. Bergen: Fagbokforlaget.

Dietrich, S. (2014). Reflections on core aspects of diaconal theory. I S. Dietrich, K. Jørgensen, K. K. Korslien \& K. Nordstokke (Red.), Diakonia as Christian social pactice: An introduction (s. 13-27). Oxford, England: Regnum Books International.

Grung, A. H. (2011). Dialog - målet er ikke enighet. Tidsskrift for Norsk psykologforening, 48(6), 561.

Ham, C. (2014). Empowering diakonia: A perspective from the World Council of Churches. I S. Dietrich, K. Jørgensen, K. K. Korslien \& K. Nordstokke (Red.), Diakonia as Christian social practice: An introduction (s. 13-27). Oxford, England: Regnum Books International.

Hegstad, H. (2009). Den virkelige kirke. Bidrag til ekklesiologien. Trondheim: Tapir Akademisk Forlag

Jordheim, K. (2009). Plan for diakoni i Den norske kirke - en presentasjon. I K. I. Johannessen, K. Jordheim, K. K. Korslien, Diakoni: en kritisk lesebok. Trondheim: Tapir Akademisk Forlag.

Jordheim, K. (2014). Bridge-building and go-between: The role of the deacon in church and society. I S. Dietrich, K. Jørgensen, K. K. Korslien \& K. Nordstokke (Red.), Diakonia as Christian social practice. An introduction. Oxford, England: Regnum Books International.

Kirkerådet. (2008). Plan for diakoni i Den norske kirke. Oslo: Kirkerådet. 
Lid, I. M. (2013). Universell utforming. Verdigrunnlag, kunnskap og praksis. Oslo:

Cappelen Damm Akademisk.

Lid, I. M. (2018). Diakoni og velferdsstat. Oslo: Gyldendal Akademisk.

Nordstokke, K. (2002). Det dyrebare mennesket. Oslo: Verbum.

Norges Kristne Råd (NKR). (2017). Tilvorelsens gave. Kalt til å voere kirke av alle og for alle. Norges Kristne Råds skriftserie, nr. 20. Oslo: Norges Kristne Råd.

Shier, H. (2001). Pathways to participation: Openings, opportunites and obligations. A new model for enhancing children's participation in line with Article 12.1 of the United Nations Convention on the Rights of the Child. Children \& Society, 15, 107-117.

Strømmestiftelsen. (2019). Hentet 20.10.19 fra https://strommestiftelsen.no/ingenskal-utelates-men-hvordan-inkludere.

Winsvold, A. \& Falck, S. (2011). Modeller for å sikre medbestemmelse og medinnflytelse blant utsatte ungdomsgrupper. (Notat 5/2011.) Oslo: Norsk institutt for forskning om oppvekst, velferd og aldring (NOVA). 



\title{
KAPITTEL 6
}

\section{Sårbarhet, mangfold og menneskerettigheter}

\section{Hans Morten Haugen}

VID vitenskapelige høgskole

\begin{abstract}
The article examines recent understandings of vulnerability and exposedness, and studies proving that people with disabilities are more exposed to violence, discrimination, and various forms of exclusion. Diversity has been elevated as a value, both in societies and in churches. The UN Convention on the Rights of Persons with Disabilities (CRPD) is the only human rights treaty that names specific human rights principles, and one of these principles is diversity. There are also opposing trends to the enhanced recognition of diversity, summarized in three points: preservation of status quo; highlighting majority normality; and budgetary efficiency are given priority over empowering solutions. The Church of Norway, inspired by the World Council of Churches, wants to promote inclusion and empowerment, but is itself lagging behind, for instance in providing access to enabling technology.
\end{abstract}

Keywords: ableism, Ecumenical Disability Advocates Network (EDAN), UN Convention on the Rights of Persons with Disabilities, inclusive development

\section{Innledning}

Dette kapitlet benytter nye perspektiver på sårbarhet der man går vekk fra å snakke om sårbare grupper av personer og i større grad snakker om personer i sårbare situasjoner (Strand \& Ikdahl, 2017, s. 126-127; Sandberg, 2015; Lid, 2013a, s. 27; Haugen, 2010, s. 210). Det er holdninger og praksiser hos enkeltpersoner og institusjoner som medfører at en person

Sitering av denne artikkelen: Haugen, H. M. (2020). Sårbarhet, mangfold og menneskerettigheter. I I. M. Lid \& A. R. Solevåg (Red.), Religiøst medborgerskap: Funksjonshemming, likeverd og menneskesyn (Kap. 6, s. 129-151). Oslo: Cappelen Damm Akademisk. https://doi.org/10.23865/noasp.10o.ch6 Lisens: CC BY-NC-ND 4.O. 
med funksjonsnedsettelser (eller en kvinne, en albino eller en homofil) er sårbar i noen samfunn, men ikke $i$ andre.

Et slikt nytt perspektiv på sårbarhet finnes hos Sturla Stålsett, som understreker sårbarheten som «en betingelse for det å kunne handle etisk. Derfor må også politikken bygge på en dypere forståelse av sårbarheten som grunnvilkår og som verdi for menneskelig fellesskap» (Stålsett, 2017, s. 260; se også Butler et al., 2016; Fineman, 2008). Denne måten å se sårbarhet på innebærer også å se alle mennesker som utlevert til hverandre. Dersom vi forsøker å gjøre oss usårbare, vil vi kunne ende opp med umenneskelige samfunn.

Sårbarhet som noe allmennmenneskelig tydeliggjøres i dokumentet Tilverelsens gave - opprinnelig utgitt av Kirkenes Verdensråd som The Gift of Being (Norges Kristne Råd [NKR], 2017, avsnitt 85; se også Den norske kirke, 2016). Også innenfor helseforskning finnes en erkjennelse av sårbarhet som avgjørende for å fremme gjensidig avhengighet og relasjonalitet (Herring, 2016; Malterud \& Solvang, 2005). Gitt at vi erkjenner alle mennesker som sårbare, kan vi bruke begrepet «utsatthet» for å beskrive personer eller grupper av personer som lever i spesielt krevende situasjoner.

Problemstillingen som kapitlet søker å bevare, lyder: Hva er kjernen i nyere forståelser av inkluderende tilrettelegging for personer med funksjonsnedsettelser - som også målbåret av Kirkenes Verdensråd og har Den norske kirke på sentralt nivå latt seg inspirere av slike forståelser?

Selv om holdningsendringer hos enkeltpersoner og kirkelig språk og praksiser på lokalt nivå ikke er en del av problemstillingen, betyr ikke dette at slike endringer ikke er relevant. Kapitlet adresserer ikke disse spørsmålene, men søker å vise at ved å erkjenne sårbarhet som ressurs, vil dette fremme mellommenneskelig samhandling forankret i forståelsen av vår gjensidige avhengighet. Gjennom en etisk refleksjon rundt funksjonsnedsettelser, sårbarhet og mangfold vil jeg vise hvordan menneskerettighetene gir retning for arbeidet med å fremme likeverdig deltakelse og mer inkluderende samfunn. Kjersti Skarstad viser hvordan moralsk samhandling og nye relasjoner som anerkjenner mangfold, er avgjørende for bedre menneskerettighetsbeskyttelse (Skarstad, 2019, 
s. 93-100; 2018a), men dette må suppleres av påvirkningsarbeid overfor myndighetene (Lang et al., 2011). Kapitlet er forankret i en maktkritisk tilnærming der begrepet «ableisme» betegner forskjellsbehandling eller ulik behandling av mennesker på grunn av faktiske eller forestilte funksjonsnedsettelser.

Etter en gjennomgang av menneskerettighetene og en kort gjennomgang av noen av uenighetene mellom norske myndigheter og FNs komité for personer med funksjonsnedsettelser vil jeg særlig vurdere Den norske kirkes tiltak, med vekt på tilrettelegging for likeverdig deltakelse og det å løfte frem mangfold. Det er her relevant å peke på at begrepet «rimelig tilrettelegging» defineres i artikkel 2 av CRPD som

[...] nødvendig og hensiktsmessig endring og justering som ikke innebærer en uforholdsmessig eller utilbørlig byrde, når det i et bestemt tilfelle er behov for det, for å sikre at mennesker med nedsatt funksjonsevne kan nyte eller utøve alle menneskerettigheter og grunnleggende friheter på lik linje med andre.

(CRPD, 2014, artikkel 2)

Rimelig tilrettelegging kan forstås som en individuell rettighet, men sikringen av denne rettigheten begrenses av forhold som forstås å utgjøre en utilbørlig byrde. Hva som utgjør en utilbørlig byrde, må avklares i det enkelte tilfellet, og det er plikthaveren som må vise at det konkrete tiltaket utgjør en uforholdsmessig eller utilbørlig byrde.

Et perspektiv som var fremme hos Kirkenes Verdensråd tidligere, nemlig begrepet «differently abled» (Kirkenes Verdensråd, 1998) - som jeg velger å oversette til «med ulike evner» - vil løftes frem. Jeg vil avslutte med noen overordnede perspektiver for å forklare nedlatende holdninger: (i) usynliggjøring, (ii) ønsket om «normalitet» og (iii) utestenging, som kan lede til selvstigmatisering. Jeg vil ikke drøfte tiltak for å bekjempe vold mot mennesker med funksjonsnedsettelser, selv om flere studier viser at minst én av ti personer med funksjonsnedsettelser utsettes for vold (Olsen et al., 2016, s. 31; Ramm, 2010, s. 62; se også Borg, 2008; Vårt Land, 2016). 


\section{Menneskerettigheter}

Jeg vil særlig utvikle videre en menneskerettighetstenkning forankret i en forståelse av de sju menneskerettighetsprinsippene. Et menneskerettighetsprinsipp spesifiseres i FNs såkalte «Common understanding» som avledet fra internasjonale menneskerettighetsinstrumenter (se UNICEF, 2003, punkt. 1). Slike prinsipper skal - sammen med de substansielle rettighetene - «styre alt samarbeid og prosjektarbeid i alle sektorer og i alle faser av prosjektets gjennomføring» (s. 1, min oversettelse).

For å tydeliggjøre kjernen i menneskerettighetsprinsippene kan vi si at disse utgjør grunnleggende hensyn av overordnet karakter som må etterleves i enhver beslutningsprosess, formulert som «obligation of conduct» («fremgangsmåteplikter») (Wolfrum, 2010). Disse pliktene er knyttet til «obligations of result» («plikter til å oppfylle»), altså den faktiske realiseringen av substansielle menneskerettigheter. Statene har de folkerettslige pliktene, men bred mobilisering av alle med moralske plikter (personer og alle samfunnsorganer) er avgjørende for at rettighetene faktisk skal realiseres.

Sju menneskerettighetsprinsipper er løftet frem av FNs organisasjon for mat og landbruk (FAO, 2018): menneskeverd, ikke-diskriminering, lovbasert atferd, ansvarlighet, åpenhet, deltakelse og myndiggøøring. Merk at både ikke-diskriminering og deltakelse er både substansielle menneskerettigheter og menneskerettighetsprinsipper. Disse sju prinsippene har generell anvendelighet. Som forklart nedenfor gjelder de menneskerettighetsprinsippene som spesifiseres i CRPD, kun i relasjon til denne konvensjonen.

De to første prinsippene handler om hvordan myndighetene møter den enkelte. Menneskerettighetene er forankret i forståelsen av alle menneskers like menneskeverd, uavhengig av intellektuelle og fysiske evner. Ikke-diskriminering handler også om at ulike tilfeller må behandles ulikt, og at det er mulig å forskjellsbehandle for å fremme substansiell rettferdighet. De tre neste prinsippene handler om overordnede hensyn i myndighetsutøvelse, slik at denne blir lovforankret, basert på mest mulig åpne prosesser og med mulighet for å holde dem som utøver makt, til ansvar for sin maktutøvelse. De to siste prinsippene er nedenfra-perspektiver som igjen tar utgangspunkt i den enkelte, men da den enkelte som 
medlem av et fellesskap. Myndiggjøring - som må være målsettingen for alle prosesser og vedtak som berører enkeltpersoner - må skje også på familie- og lokalsamfunnsnivå.

Innenfor alle disse sju prinsippene kan vi bruke involvering/ikkeinvolvering eller synliggjøring/usynliggjøring av mennesker med funksjonsnedsettelser som illustrasjon. CRPD er den eneste internasjonale konvensjonen som nedfeller spesifikke menneskerettighetsprinsipper og som understreker at disse gjelder «denne konvensjon» (artikkel 3):

(a) verdighet

(b) ikke-diskriminering

(c) deltakelse og inkludering

(d) respekt for forskjeller og mangfold

(e) like muligheter

(f) tilgjengelighet

(g) likestilling mellom menn og kvinner

(h) respekt for utviklingsmulighetene til barn med nedsatt funksjonsevne

Vi ser at de tre første er sammenfallende med de generelle menneskerettighetsprinsippene. Jeg vil senere undersøke særlig prinsipp (d) om respekt for forskjeller og mangfold og knytte denne diskusjonen til prinsippet om myndiggjøring. Samtidig er det viktig at både de substansielle menneskerettighetene og menneskerettighetsprinsippene er udelelige og gjensidig avhengige av hverandre.

Tre tidligere FN-dokumenter er relevante, for det første FN-erklæringen om personer med psykisk utviklingshemming (norske myndigheter bruker nå bare begrepet «utviklingshemming», mens den engelske tittelen på erklæringen var «mentally retarded») (De forente nasjoner [FN], 1971). I tråd med CRPD bruker jeg begrepet «intellektuell funksjonsnedsettelse» (se også NOU 2016: 17). For det andre FNs erklæring om rettighetene til mennesker med nedsatt funksjonsevne (FN, 1975). For det tredje FNs standardregler for å fremme likestilling for personer med funksjonsnedsettelser (FN, 1993; se også Samarbeidsrådet for tros- og livssynssamfunn, 2013, s. 11-12), som overvåkes av FNs kommisjon for sosial utvikling. 
Likevel representerer CRPD fra 2006 et tidsskille. For det første er den bindende for de 177 statene som har ratifisert den. For det andre legges en ny forståelse til grunn, som av Skarstad (2019, s. 48) er presisert å omhandle fjerning av samfunnshindre, tilrettelegging og beskyttelse mot krenkelse. Lid (2013b) argumenterer for en relasjonsmodell, særlig for universell utforming. Som vi så ovenfor, vektlegger Skarstad (2019, s. 93-100; 2018a) også det relasjonelle i menneskerettighetsrealiseringen.

De ulike menneskerettighetskomiteene som overvåker, tydeliggjør forpliktelser og gir anbefalinger for gjennomføringen av de ulike konvensjonene, har presisert menneskerettighetsvernet for personer med funksjonsnedsettelser (FNs komité for avskaffelse av diskriminering av kvinner, 1991; FNs komité for økonomiske, sosiale og kulturelle rettigheter, 1994; FNs komité for barns rettigheter, 2006). FNs komité for barns rettigheter vektlegger barn med funksjonsnedsettelser sin rett til å bli hørt og tatt hensyn til, i tråd med artikkel 12 i barnekonvensjonen (FNs komité for barns rettigheter, 2006, avsnitt 33). Tydeligst er imidlertid FNs komité for rettighetene for personer med funksjonsnedsettelser (2014, avsnitt 3), som i sin første tolkningskommentar understreker at statene må endre sin politikk til å gi tilstrekkelig beslutningsstøtte, slik at personen - så langt det er mulig - selv kan ta beslutninger. Tilsvarende tilrettelegging for deltakelse av personer med ulike funksjonsnedsettelser skal skje på alle samfunnsarenaer.

I FNs bærekraftsmål er personer med funksjonsnedsettelser omtalt under målsetting 4.5 (utdanning), 8.5 (anstendig arbeid), 10.2 (ulikhet) samt 11.2 og 11.7 (bærekraftige byer). For at målet om avskaffelse av fattigdom skal kunne nås, kreves langt større innsats for og samarbeid med personer med funksjonsnedsettelser (Atlas-alliansen, 2018).

\section{Om deltakelse og å bli hørt}

Det er nødvendig med en tydeliggjøring av plikten til å legge til rette for mest mulig likeverdig deltakelse på alle arenaer av samfunnslivet og for å bli hørt. Det generelle prinsippet «ingenting om oss uten oss» er selvskrevet, som understreket av likestillings- og diskrimineringsombudet 
(Ørstavik, 2014). Hun peker på at FN-komiteen som etterser gjennomføringen av CRPD, kun består av medlemmer med funksjonsnedsettelser, og fortsetter: «En politikk som er utformet langt fra de den handler om blir sjelden eller aldri bra, og en politikk uten involvering er i strid med menneskerettighetene» (Ørstavik, 2014).

To FN-konvensjoner vektlegger direkte deltakelse i beslutningsprosessen: barnekonvensjonens artikkel 12 (om retten til å gi uttrykk for egne synspunkter og bli hørt) og CRPD-artiklene 7 («Barn med nedsatt funksjonsevne»), 12 («Likhet for loven») og 29 («Deltakelse i det politiske og offentlige liv»). Det er også relevant at retten til å bli fullt inkludert og kunne delta i samfunnet samt retten til deltakelse i kulturlivet anerkjennes i artiklene 19 og 30 i CRPD.

Skarstad (2018b) operasjonaliserer særlig rettighetene for personer med intellektuell funksjonsnedsettelse til å handle om selvbestemmelse. Selvbestemmelse for personer med intellektuell funksjonsnedsettelse er tydeliggjort i formålsbestemmelsen til kapittel 9 i helse- og omsorgstjenesteloven. Selvbestemmelse er også tydeliggjort i formålsbestemmelsen i $\$ 1$ i psykisk helsevernloven, som ble revidert i 2017 ved å tilføye «selvbestemmelsesrett». Det er blitt foreslått at psykisk helsevernloven skal erstattes av en ny lov, tvangsbegrensningsloven, der det også er foreslått å ta inn tvangsbestemmelser fra andre lover (NOU, 2019, s. 14).

Det er uenighet mellom norske myndigheter og komiteen for rettighetene til mennesker med nedsatt funksjonsevne om hvor langt selvbestemmelsesretten faktisk rekker, som uttrykt i Norges tolkningserklæringer til tre bestemmelser avgitt da CRPD ble ratifisert. For det første anfører Norge at artikkel 12 («Likhet for loven») «tillater tilbakekalling av rettslig handleevne ... i tilfeller der slike tiltak er nødvendige...» Den såkalte Tolga-saken - der tre brødre ble gitt diagnosen psykisk utviklingshemming og satt under vergemål uten brødrenes viten og samtykke (Regjeringen, 2019) - viser hvordan selvbestemmelse er blitt reelt ignorert av flere myndighetsorganer. For det andre anfører Norge at artiklene 14 («Frihet og personlig sikkerhet») og 25 («Helse») tillater «tvungen omsorg eller behandling av personer ... når omstendighetene gjør slik behandling nødvendig som en siste utvei» (Regjeringen, 2013; for støtte til regjeringen 
og kritikk av Likestillings- og diskrimineringsombudet, se Syse, 2016, s. $466-468,480)$.

Ordlyden i artikkel 12 i CRPD krevde at den norske vergemålsordningen ble revidert før Norge kunne ratifisere CRPD. Skarstad finner at vergene i liten grad bidrar til å ivareta rettighetene og interessene til personer med intellektuell funksjonsnedsettelse (Skarstad, 2018b). Hun kritiserer at det ikke er nasjonale krav til kunnskap om menneskerettighetene eller stilles andre kompetansekrav til verger, men påpeker at Fylkesmannen i Oslo og Akershus gjennomfører egne kurs for verger.

En inngående rettslig drøfting faller utenfor dette kapitlet, men det er verdt å merke seg at vergemålsloven $\$ 33$ er den relevante bestemmelsen som skal sikre selvbestemmelse for den som er satt under vergemål. Første ledd innledes med at «[v]ergen skal så vidt mulig høre den som er satt under vergemål» (vergemålsloven, 2013, \$33, min utheving). Annet ledd bruker formuleringen «ikke er i stand til å forstå» for når en beslutning kan fattes selv om personen som er satt under vergemål, motsetter seg denne. En legeerklæring skal kunne fastslå når slik manglende forståelse foreligger. Tredje ledd hjemler klagemulighet til Fylkesmannen og understreker at i prosessen med å avklare hva en person mener, skal ektefelle eller samboer få uttale seg.

For å foreslå forbedringer i behandlingen av mennesker med intellektuell funksjonsnedsettelse ble det såkalte rettighetsutvalget nedsatt (NOU, 2016, s. 17). Åtte såkalte løft identifiseres, der det første handler om selvbestemmelse og rettssikkerhet med følgende konkretiseringer (NOU 2016: 17):

(i) gratis rettshjelptiltak

(ii) rett til beslutningsstøtte

(iii) endrede regler for fratakelse av rettslig handleevne

(iv) endrede regler om bruk av tvang overfor personer med utviklingshemming

Som vi har sett ovenfor, ble selvbestemmelse i 2017 tatt inn i formålet til psykisk helsevernloven. Det sjuende «løftet», om koordinerte tjenester, 
foreslår en ny bestemmelse i kommuneloven som tydeliggjør kommunens ansvar (NOU 2016: 17, s. 209).

Rettighetsutvalget hadde bare ett medlem som representerte organisasjoner for personer med funksjonsnedsettelser - en styreleder i Autismeforeningen - og ett medlem trakk seg som følge av svak representasjon fra disse organisasjonene (Avisa Nordland, 2015; se også Fellesorganisasjonen [2015] om FOs uttreden fra referansegruppen). Selv om statsråden lovet en plass i utvalget for Norsk Forbund for Utviklingshemmede (NFU) (NFU, 2016; Barne- og likestillingsdepartementet, 2015), lyktes det bare å erstatte det avgåtte medlemmet med en akademikerrepresentant (NOU 2016: 17, s. 21). NFU er imidlertid fornøyd med utvalgets innstilling (NFU, 2016). I juni 2018 fattet Stortinget i alt 14 vedtak, de fleste bestillinger til en stortingsmelding om sikring av utviklingshemmedes menneskerettigheter, deriblant krav om å vurdere erfaringene med vergemålsloven og sikre retten til trosutøvelse (Stortinget, 2018).

Rettighetsutvalget møtte også kritikk for å legge tidligere statlig ansvar over på kommunene, konkret at kommunene skal sørge for «tilrettelagt arbeid til personer som har ytelsen ung ufør» (Wangen, 2017; NOU 2016: 17, s. 182, 219-220, 249-253). Dette kan innebære reelle svekkelser i tilbudet når vi vet hvor ulike forutsetninger ulike kommuner har, og hvor mye større vekt som nå legges på hensynet til det kommunale selvstyret i forvaltningsloven $\$ 34$, annet ledd (lov om endringar i forvaltningslova m.m., 2017). Mange unge uføre kan erfare at de ikke får den nødvendige tilretteleggingen, og deres særlige utsatthet vil da vedvare og til og med forsterkes.

\section{Mangfold og positiv forskjellsbehandling}

Inger Marie Lid (2012a) kritiserer Martha Nussbaum, som vektlegger evner og egenskaper med tanke på å definere et menneskeliv. Lid har også anerkjent Nussbaums bidrag til forskning på personer med funksjonsnedsettelser (Lid, 2017; se også Lid, 2012b, s. 122-124). Lid bruker begrepene «mangfold» og «funksjonsvariasjon», og det sistnevnte brukes hyppigere i Sverige enn i Norge. I FN er det begrepet mangfold som brukes. 
Ett av prinsippene i CRPD handler om respekt for forskjeller og mangfold, eller mer konkret «respekt for forskjeller og aksept av mennesker med nedsatt funksjonsevne som en del av det menneskelige mangfold og av menneskeheten» (FNs komite for rettighetene for personer med funksjonsnedsettelser, 2014, s. 9).

Det er en bred anerkjennelse av mangfold som kommer til uttrykk i dette prinsippet, og hele menneskerettighetsideen er basert på respekt for slikt mangfold. Samtidig som mangfold anerkjennes innenfor eksempelvis kultur, seksuell orientering og funksjonsevne - sistnevnte i økende grad også i kirkene (se nedenfor) - kan mennesker som tilhører ulike minoriteter, oppleve at de reelt sett behandles dårligere enn andre. Som nevnt innledningsvis kan prinsippet om ikke-diskriminering også innbefatte positiv forskjellsbehandling dersom dette skjer for å fremme substansiell likhet.

Det går an å skille mellom tre nivåer av likhet: formell likhet, mulighetslikhet og resultatlikhet. Hver av disse kan knyttes til Nancy Frasers tre dimensjoner, det vil si anerkjennelse (den sosiokulturelle sfæren, formell likhet), deltakelse (den politiske sfæren, mulighetslikhet) og fordeling (den økonomiske sfæren, resultatlikhet) (Fraser, 1996). For personer med funksjonsnedsettelse er alle tre høyst relevante. Fraser drøfter om generelt økt vekt på identitetspolitikk kan svekke betydningen av fordelingspolitikk, og hun svarer bekreftende på dette. Med tydeligere kopling til menneskerettigheter knytter Sandra Fredman disse tre (anerkjennelse, deltakelse og fordeling) sammen med en fjerde dimensjon - kalt forvandling - til resultatlikhet (Fredman, 2016).

Personer med funksjonsnedsettelser mangler i mange stater et effektivt rettsvern fordi de i altfor stor grad er usynlige, isolert og kan overses i politiske prioriteringskamper. Disse vil derfor ikke ha noe å tape på å styrke sin identitet som et fellesskap og øke sin synlighet - for derigjennom å søke å påvirke fordelingskampen i samfunnet, blant annet ved å øke sin deltakelse i ulike beslutningsfattende fora. Rettighetskamper er en integrert del av dette. Jeg har vist at ingen samfunn utvikler seg sosialt, økonomisk og politisk uten gjennom sosial kamp (Haugen, 2016). Konkret skjer dette dersom de med svakere maktposisjon makter å agere sammen og stiller krav til dem med makt, som på sin side må innse at de 
vil ha interesse av å åpne for at flere får delta i beslutningsprosessene. Når flere personer med ulik sosial status blir hørt, fremmes både mangfold og inkludering. Dette resulterer i en inkluderende samfunnsutvikling. Dersom personene med makt ønsker å bevare status quo, vil samfunnet stagnere - og ofte utvikle seg i voldelig retning, siden vold kan bli de mektiges forsvar og de ekskludertes svar.

Styrket rettslig status i møte med myndighetene er positivt, men samfunn opprettholdes også av trygghet i de nære familierelasjoner og av økt gruppebasert sosial samhandling (Honneth, 2003, s. 138-142). Anerkjennelse på disse tre nivåene - familie, samfunn og stat - vil skape større myndiggjøring for den enkelte, for familien og for samfunnet. Inkludering av personer med funksjonsnedsettelser skjer i for liten grad, særlig når det gjelder barn og unge, og det økte prestasjonspresset løftes frem som en forklaring (Tøssebro \& Wendelborg, 2014; se også Bufdir, 2018; Ramm \& Otnes, 2013). Andelen personer med funksjonsnedsettelser som var i arbeid, var lavere i 2017 enn i 2000 (Statistisk sentralbyrå [SSB], 2018, tabell 2; SSB, 2005).

\section{Nye forståelser også hos sentrale organer i Den norske kirke?}

Før vi vurderer hva Den norske kirke har gjort, er det relevant å peke på at i Norge ble diskriminering av personer med funksjonsnedsettelser først ulovlig gjennom den tidligere diskriminerings- og tilgjengelighetsloven, som trådte i kraft i 2009 (diskriminerings- og tilgjengelighetsloven, 2008). Straff for diskriminerende eller hatefulle ytringer mot personer med nedsatt funksjonsevne ble først forbudt med den nye straffeloven, som trådte i kraft i 2015 (straffeloven, 2008). Utviklingen har altså gått langsomt, også innenfor det politiske liv i et land vi liker å tro ligger i forkant.

Vi kan skille mellom tiltak som vedrører forhold internt i Den norske kirke, og tiltak der Den norske kirke søker å påvirke offentlige myndigheter. Min antakelse er at det sistnevnte er lettere enn det førstnevnte. Jeg gjennomgår relevante vedtak over en viss tidsperiode, også for å vise endringer i forståelser. Som eksempel på den tenkningen som preget Den 
norske kirke før år 2000, skal vi bruke rapporten fra et utvalg nedsatt av Bispemøtet som listet opp «fysisk funksjonalitet» og «fysisk helse» som kriterier for ansettelse i prestestilling (Utvalg nedsatt av Bispemøtet, 1997, s. 24-25). Disse møtte ingen innsigelser da rapporten med kriteriene ble vedtatt (Bispemøtet, 1997).

Kirkenes Verdensråd er det internasjonale kirkeorganet som mest tydelig har arbeidet for nye prioriteringer i kirkene i møte med personer med funksjonsnedsettelser. I arbeidet frem mot generalforsamlingen i 1998 ble begrepet «differently abled», altså «med ulike evner», brukt. Ifølge Ecumenical Disability Advocates Network (EDAN) ble begrepet brukt frem til CRPD ble vedtatt, men deretter har EDAN brukt samme betegnelse som FN, altså «personer med funksjonsnedsettelser» (Kilonzo, 2018).

Det er ikke mulig å finne kirkemøtevedtak fra Den norske kirke før 2000 som tydeliggjør et særlig ansvar for å tilrettelegge for likeverdig deltakelse av personer med funksjonsnedsettelser. Dette betyr naturligvis ikke at det ikke har skjedd tilretteleggingsarbeid lokalt. I en overordnet bemanningsplan for kirkelige stillinger fra 2001 heter det (etter en understreking av at Den norske kirke skal være en kirke for alle) at «[d]et inkluderer også mennesker med ulike former for funksjonshemninger. Det er viktig at en også sentralt i kirken har fagpersoner som ivaretar denne gruppens interesser» (Kirkerådet, 2001, s. 74). Begrepet «gruppen» og det at «vi» skal ivareta «dem», viser en begrepsbruk vi antakelig ikke ville ha sett i dag.

Kirkemøtet ba i 2006 om at kirkelige arbeidsgivere skal gå lenger i å legge til rette for mennesker med funksjonsnedsettelser enn det som følger av norsk lov (Kirkemøtet, 2006, vedtak 2). I 2012 brukte Kirkemøtet ordene «likeverd, inkludering og tilrettelegging» i tittelen og også betegnelsen "personer med utviklingshemming» (Kirkemøtet, 2012). Dokumentet Tilvoerelsens gave understreker at «[e]t bredere perspektiv lar oss gjenkjenne gaven i personen som lever med nedsatt funksjonsevne, heller enn i funksjonsnedsettelsen som sådan» (NKR, 2017, s. 15). Jeg deler denne forståelsen, og begrepet «differently abled» («med ulike evner») får enda tydeligere frem de ressursene som personer med funksjonsnedsettelser bærer med seg. 
Som konkret hjelp i arbeidet for og med mennesker med intellektuell funksjonsnedsettelse i kirken publiserte Kirkerådet i 2016 heftet Likeverd - inkludering - tilrettelegging (Kirkerådet \& HEL, 2016), og to artikler ble publisert i Luthersk Kirketidende (Torgauten, 2016a, 2016b). Under overskriften «Den egentlige årsak» søker Tor Ivar Torgauten å finne svar på hvorfor mennesker med intellektuell funksjonsnedsettelse ikke opplever å bli godt inkludert i kirkene - og svaret er de holdningene de møter (Torgauten, 2016a).

Kun i det siste av Den norske kirkes flerårige visjonsdokumenter for perioden 2009-2014, 2015-2018, 2019-2021 (Kirkerådet, 2018; Kirkemøtet, 2008, 2014a) omtales mennesker med funksjonsnedsettelser. I arbeidet med visjonsdokumentet for 2019-2021 ble det foreslått fra Kirkerådets sekretariat å inkludere punktet «[k]irken forsvarer rettigheter for mennesker med funksjonsnedsettelser» (Kirkerådet, 2018, s. 5). Dette punktet kom ikke inn i det forslaget som gikk til Kirkemøtet, som derimot vedtok - under punktet om dåp og trosopplæring: «Kirken legger til rette for mennesker med funksjonsnedsettelser» (Kirkemøtet, 2018). Vi så ovenfor at mangfold er ett av prinsippene i CRPD. Mangfold ble tydelig verdsatt av kirkemøtekomiteen i 2015 i saken om kirke og helse: «Det menneskelige mangfoldet må oppvurderes som en motvekt til ensrettingen av idealer for kropp, utseende og funksjonsevne» (Kirkemøtet, 2015, s. 3). En slik oppvurdering må forstås med utgangspunkt $i$ at ensretting av idealer oppfattes som en trussel mot det genuint menneskelige.

Den norske kirkes visjonsdokument for 2009-2014 sier at kjennetegnet på en «åpen» kirke skal operasjonaliseres «ved å utvikle fellesskap som verdsetter mangfold og respekterer ulikheter» (Kirkemøtet, 2008, s. 2). Å verdsette mangfold rommer en sterk anerkjennelse. I de to siste visjonsdokumentene heter det følgende under kjennetegnet «åpen»: «Vi er et fellesskap preget av likeverd, deltakelse og respekt for mangfold» (Kirkemøtet, 2018, s. 2; 2014a, s. 4). Vi ser altså at uttrykket «verdsette» er blitt erstattet av «respekt» i de to siste visjonsdokumentene. Det er vanskelig å tolke den nye ordbruken som en svakere anerkjennelse av mangfold.

Hva er realiteten hos Den norske kirke med tanke på å tilrettelegge for dette mangfoldet? Ifølge Magne Bjørndal (2018) er ikke tilretteleggingen 
bra. Han peker på at han som blind prest ikke kan bruke de produktene som Kirkepartner, hovedleverandøren av IT-tjenester til Den norske kirke, tilbyr. I den tidligere diskriminerings- og tilgjengelighetsloven som trådte i kraft i 2009, var det i paragraf 11 et krav om universelt utformede IT-systemer innen 2021 for eksisterende IT-systemer (diskriminerings- og tilgjengelighetsloven, 2008), en bestemmelse som er videreført i paragraf 41 i likestillings- og diskrimineringsloven som trådte i kraft i 2018. Altså har verken Den norske kirke eller norske myndigheter hatt det travelt på dette området. Nye IT-systemer skulle ha vært universelt utformet fra 1. juli 2011.

En vurdering av hva Den norske kirke har gjort internt, kan altså oppsummeres med at det er en betydelig dreining i omtalen og verdsettingen av personer med funksjonsnedsettelser. Selv om jeg ikke har grunnlag for å si noe om universell utforming generelt, er det særlig ett område innenfor universell utforming som er kritikkverdig, nemlig IT-systemene.

I arbeidet med å søke å påvirke offentlige myndigheter er det verdt å merke seg menneskerettighetssaken på Kirkemøtet i 2014. To av de fire «oppfordringene» til norske myndigheter omhandlet mennesker med nedsatt funksjonsevne (Kirkemøtet, 2014b, s. 6):

(i) ratifikasjon av blant annet tilleggsprotokollen til CRPD for å tillate individklager

(ii) økt vekt på å bekjempe diskriminering, blant annet på bakgrunn av nedsatt funksjonsevne

Stortinget valgte å ikke ratifisere noen av de aktuelle tilleggsprotokollene, og som nevnt ovenfor trådte den nye likestillings- og diskrimineringsloven i kraft i 2018. Den norske kirke er generelt opptatt av å øke deltakelsen til personer med funksjonsnedsettelse på alle samfunnsområder. Ungdommens kirkemøte minner om at det i all kommunikasjon med barn og unge med funksjonsnedsettelser skal tydeliggjøres at aktiviteten er tilrettelagt (Ungdommens kirkemøte, 2015, s. 2). I 2016 advarte Kirkerådet mot at kommuneloven ble formulert slik at den åpner for at kommunene kan slå sammen eldreråd og råd for personer med funksjonsnedsettelse. Kirkerådet peker på at «eldre, mennesker med 
funksjonsnedsettelser og ungdom er underrepresentert i folkevalgte organ» (Kirkerådet, 2016, s. 2). I kommuneloven som ble vedtatt i 2018 (lov om endringar i kommunelova m.m., 2017), skilles det mellom disse to rådene, og et ungdomsråd er også påkrevd i hver kommune. Disse to eksemplene mener jeg illustrerer at Den norske kirke krever tiltak fra myndighetene for bedre inkludering.

\section{Avsluttende drøfting}

Den norske kirke er formet av sin tid, også i møtet med personer med funksjonsnedsettelser. Lokal tilrettelegging for deltakelse og målrettet diakoni, i første rekke for døve, er en del av dette bildet. I dette kapitlet er det ikke grunnlag for å hevde at diakonien i møte med personer med funksjonsnedsettelser har vært tidlig ute med å vektlegge myndiggjøring, men i dag blir det lagt vekt på tilrettelegging for likeverdig deltakelse, i alle fall i prinsipielle vedtak. I realiteten hindres slik likeverdig deltakelse, blant annet ved at Den norske kirkes IT-leverandør ikke oppfyller norsk lov.

Diskriminering og ekskludering av personer med funksjonsnedsettelser er først og fremst et problem for dem som ikke får delta i den grad de ønsker, men det er også et problem for samfunnet ved at vi får et råere samfunn, og fordi ressurser mange besitter, ikke blir tatt i bruk. På individnivå kan vi skille mellom tre skadelige holdninger:

(i) Interesse av å bevare status quo, der usynliggjøring kan være et effektivt virkemiddel.

(ii) Ønsket om «normalitet», forstått som dominerende kjennetegn ved majoriteten, innebærer at minoriteters kjennetegn vurderes som uønsket.

(iii) Utestenging ved ikke å legge til rette, og ved å prioritere budsjettmessig effektivitet fremfor myndiggjørende løsninger.

Alle disse holdningene, ytringene og manglende tiltakene opprettholder «utsattheten» for dem som rammes. Disse tre forklaringene vil drøftes kort nedenfor, med innsikt fra egen forskning på ideologier som søker å holde grupper og personer nede og utestengt (Haugen, 1996), 
samt med innsikt i inkluderende kontra ekskluderende identitetsbygging (Haugen, 2017) og i hva som fremmer og hemmer stigmatisering og selvstigmatisering.

\section{Status quo og usynliggjøring}

Det at nye grupper søker å øke sin innflytelse i samfunnet, innebærer at etablerte makthierarkier vil utfordres. For dem som besitter posisjoner, oppleves dette som uønsket. Ut fra en slik forståelse kan krav fra personer med funksjonsnedsettelser oppfattes som truende, siden disse ikke respekterer samfunnets ordninger og regler. Det å oppleve at ens egen stemme og egne krav ikke blir møtt, vil medføre resignasjon eller tilmed mindreverdighetskomplekser blant personer og grupper som søker økt innflytelse. Utfallet kan bli at disse ikke deltar like aktivt i sivilsamfunnet og på politiske arenaer som de ville ha gjort dersom deres deltakelse ikke hadde møtt fordommer. I verste fall kan ulike former for selvstigmatisering bli utfallet, altså at man lettere aksepterer sin situasjon som «gitt» eller skjebnebestemt.

\section{«Normalitet» forstått som majoritetskjennetegn}

Vi ser fremvekst av en identitetsforankret majoritetssjåvinisme, særlig i møte med innvandrere (Pew Research Center, 2018, s. 23; se også Haugen, 2017). Det er funnet at personer med fordommer mot innvandrere også tenderer til å være mer positive til det Botvar omtaler som «humor om menneskelig lidelse/lyter» (Botvar, 2019, s. 47). Grad av religiøsitet er derimot ikke signifikant korrelert med holdninger til slik humor. Negative reaksjoner mot dem som faller utenfor «normaliteten», er både et samfunnsproblem og et problem for dem som rammes. 31 prosent rapporterer at de er blitt utsatt for hatytringer det siste året, slik hatytring er definert av Likestillings- og diskrimineringsombudet (Olsen et al., 2016, s. 33; se også s. 17-18). Julia Kristeva understreker at det som fremmer frastøting - også i kristendommen - er «truende annerledeshet» (Kristeva, 1982, s. 17), som «forstyrrer identitet, system, orden» (s. 4). Kristeva løfter frem Jesus som et radikalt brudd med 
frastøting basert på ytre trekk, siden han forkynner menneskets indre kvaliteter (Matt 15, 18-20) (Kristeva, 1982, s. 113-114).

\section{Utestenging ved ikke å legge til rette}

Dette kan forstås som den «snilleste» av de tre holdningene, men den kan være minst like skadelig for det psykiske velværet til dem som rammes. Det å overse hvor utsatte personer kan bli utestengt ved ikke å få den tilretteleggingen de har krav på etter både internasjonale menneskerettigheter og norsk rett, er et unnlatelsesovergrep. Dette kan smerte like mye som et aktivt overgrep.

\section{Oppsummering}

Jeg har i dette bidraget identifisert kjernen i nyere forståelser av inkluderende tilrettelegging for personer med funksjonsnedsettelser - som også er målbåret av Kirkenes Verdensråd - og hvorvidt Den norske kirke på sentralt nivå har latt seg inspirere av slike forståelser. Svaret er at vi kan se spor av endringer, men selv om Den norske kirke uttrykker at den vil gå foran, skjer dette i liten grad i praksis. For både statlige og kirkelige beslutningstakere må personer som er blitt usynliggjort, holdt nede og ekskludert, i større grad få delta og bli hørt på de arenaene hvor goder og byrder fordeles. Rimelig tilrettelegging, altså tilrettelegging som ikke innebærer en utilbørlig byrde for plikthaveren, skal sikres. Tilrettelegging for deltakelse er ikke en slik utilbørlig byrde. Ved å fremme deltakelse fra grupper av personer som er svakt representert, fremmes også mangfold. Kirkenes Verdensråd og Den norske kirke oppvurderer og verdsetter mangfold i teorien - og gradvis vil dette endre status quo. Denne måten å avgi makt på bidrar samtidig til en mer inkluderende utvikling.

\section{Referanser}

Atlas-alliansen. (2018). Guterres' Handlingsplan et vendepunkt. Hentet fra http:// atlas-alliansen.no/news/tid-for-handling-sier-guterres 
Avisa Nordland (2015, 13. februar). UiN-professor med kraftig skyts mot statsråden. Avisa Nordland. Hentet fra https://www.an.no/uin-professor-med-kraftig-skytsmot-statsraden/s/5-4-30246

Barne- og likestillingsdepartementet (2015). Supplerer rettighetsutvalget. Hentet fra https://www.regjeringen.no/no/aktuelt/supplerer-rettighetsutvalget/id2397408

Bispemøtet (1997). Sak BM 16/97 Veien til prestetjeneste i Den norske kirke. Oslo: Den norske kirke.

Bjørndal, M. (2019, 9. januar). Kyrkja ekskluderar synshemma medarbeidarar. Vårt Land. Hentet fra http://www.verdidebatt.no/innlegg/11750354-kyrkja-ekskluderersynshemma-medarbeidarar

Borg, E. (2008). Holdninger til funksjonshemmede i Norge 1999-2005. Notat 4/o8. Oslo: Norsk institutt for forskning om oppvekst, velferd og aldring (NOVA).

Botvar, P. K. (2019). Å le eller ikke le. Holdninger til religionshumor i den norske befolkningen. I P. K. Botvar, A. K. Gresaker \& O. Hovdelien (Red), Ingen spøk. En studie av religion og humor. Oslo: Cappelen Damm Akademisk.

Bufdir (2018). Levekårsstatus for personer med nedsatt funksjonsevne. Hentet fra https://www.bufdir.no/Statistikk_og_analyse/Nedsatt_funksjonsevne.

Butler, J., Gambetti, Z. \& Sabsay, L. (Red.) (2016). Vulnerability in resistance. Durham, NC og London: Duke University Press.

Den norske kirke. (2016). Å være menneske er å være sårbar. Hentet fra https:// kirken.no/nb-NO/om-kirken/aktuelt/a-vare-menneske-er-a-vare-sarbar

Fineman, M. A. (2008). The vulnerable subject: Anchoring equality in the human condition. Yale Journal of Law and Feminism, 20(1), 1-23.

FN. (1993). A/RES/48/96, Annex, Standard Rules for the Equalization of Opportunities of Persons with Disabilities.

FN. (1975). A/RES/3447 (XXX), Declaration on the Rights of Disabled Persons.

FN. (1971). A/RES/2856 (XXVI), Declaration on the Rights of Mentally Retarded Person.

Diskriminerings- og tilgjengelighetsloven. (2008). Lov om forbud mot diskriminering på grunn av nedsatt funksjonsevne. LOV-2008-06-20-42. Hentet fra https://www.regjeringen.no

FNs komité for avskaffelse av diskriminering av kvinner. (1991). General Recommendation No. 18. Disabled women.

FNs komité for barns rettigheter. (2006). General Comment 9: The rights of children with disabilities.

FNs komité for rettighetene for personer med funksjonsnedsettelser. (2014). General Comment No. 1 Article 12: Equal recognition before the law.

FNs komité for økonomiske, sosiale og kulturelle rettigheter. (1994). General Comment No. 5: Persons with disabilities. 
FNs organisasjon for mat og landbruk (FAO). (2018). The right to food - areas of work. Hentet fra http://www.fao.org/right-to-food/areas-of-work/en

FO. (2015). Trekker seg fra Rettighetsutvalgets referansegruppe. Hentet fra https:// www.fo.no/nyheter/trekker-seg-fra-rettighetsutvalgets-referansegruppearticle10532-1064.html

Fraser, N. (1996). Social justice in the age of identity politics: Redistribution, recognition, and participation. Presentert ved Stanford University, 30. april-2. mai. Hentet fra http://tannerlectures.utah.edu/_documents/a-to-z/f/Fraser98. pdf

Fredman, S. (2016). Emerging from the shadows: Substantive equality and Article 14 of the European Convention on Human Rights. Human Rights Law Review, 16(2), 273-301.

Haugen, H. M. (2017). Faith among youth in Church of Norway means greater interreligious acceptance. Nordic Journal of Religion and Society, 30(2), 97-114.

Haugen, H. M. (2016). Kampen om utviklingen. Teorier, strategier og globale utfordringer. Oslo: Cappelen Damm Akademisk.

Haugen, H. M. (2010). Inclusive and relevant language: The use of the terms autonomy, dignity and vulnerability in different contexts. Medicine, Health Care and Philosophy, 13(3), 203-213.

Haugen, H. M. (1996). Hvorfor høyreekstreme og nasjonalistiske verdier får økt oppslutning. I H. M. Haugen \& L. G. Lingås (Red.), Kampen for menneskeverdet - livssynene i møte med fremmedhat og ekstremnasjonalisme. Oslo: Universitetsforlaget.

Herring, J. (2016). Health as vulnerability; Interdependence and relationality. The New Bioethics. A Multidisciplinary Journal of Biotechnology and the Body, 22(1), 18-32.

Honneth, A. (2003). Redistribution as recognition: A response to Nancy Fraser. I N. Fraser \& A. Honneth (Red.), Redistribution or recognition? A politicalphilosophical exchange (s. 110-197). London, England: Verso.

Kilonzo, S. (2018, 2. juli). Telefonsamtale med forfatteren.

Kirkemøtet. (2018). KM 07/18 Visjonsdokument for Den norske kirke 2019-2021. Hentet fra https://kirken.no/nb-NO/om-kirken/slik-styres-kirken/kirkemotet/ kirkemotene-2003-/

Kirkemøtet. (2015). KM o9/15 Kirke og helse. Hentet fra https://kirken.no/nb-NO/ om-kirken/slik-styres-kirken/kirkemotet/kirkemotene-2003-/

Kirkemøtet. (2014b). KM o9/14 Den norske kirke og menneskerettighetene. Hentet fra https://kirken.no/nb-NO/om-kirken/slik-styres-kirken/kirkemotet/ kirkemotene-2003-/ 
Kirkemøtet. (2014a). KM 07/14 Visjonsdokument for Den norske kirke 2015-2018. Hentet fra https://kirken.no/nb-NO/om-kirken/slik-styres-kirken/kirkemotet/ kirkemotene-2003-/

Kirkemøtet. (2012). KM 9/12 Likeverd, inkludering og tilrettelegging. Mennesker med utviklingshemning i Den norske kirke. Hentet fra https://kirken.no/nb-NO/ om-kirken/slik-styres-kirken/kirkemotet/kirkemotene-2003-/

Kirkemøtet. (2008). KM 8/o8 Visjonsdokument for Den norske kirke 2009-2014. Hentet fra https://kirken.no/nb-NO/om-kirken/slik-styres-kirken/kirkemotet/ kirkemotene-2003-/

Kirkemøtet. (2006). KM 13/o6 Den norske kyrkja - ein arbeidsplass for menneske med funksjonshemmingar? Hentet fra https://kirken.no/nb-NO/om-kirken/slikstyres-kirken/kirkemotet/kirkemotene-2003-/

Kirkenes Verdensråd. (1998). 8th assembly and 5oth anniversary preparatory materials. Hearing on unit I: Unity and renewal. Hentet fra http://www.wcc-coe. org/wcc/assembly/hu1wb-e.html

Kirkerådet. (2018). KR 14.2/18. Visjonsdokument for Den norske kirke 2019-2021. Sammenstilling av høringssvar, saksdokument. Hentet fra https://kirken.no/ globalassets/kirken.no/om-kirken/slik-styres-kirken/kirkeradet/2018/januar/ kr_14_2_18_sammenfatning_av_hoeringssvar.pdf

Kirkerådet. (2016). Høringssvar - Råd i kommuner og fylkeskommuner for ungdom, eldre og personer med funksjonsnedsettelse. Hentet fra https://kirken.no/ globalassets/kirken.no/om-kirken/for-medarbeidere/horingsuttalelser/raad_i_ kommuner_og_fylkeskommuner_funksjonsnedsettelse.pdf

Kirkerådet. (2001). Bemanning i Den norske kirke. Opptrappingsplan for kirkelig bemanning. Hentet fra https://kirken.no/globalassets/kirken.no/migrering/ opptrapp.doc

Kirkerådet \& HEL. (2016). Likeverd - inkludering - tilrettelegging. Mennesker med utviklingshemning i kirken. Oslo: Kirkerådet.

Kristeva, J. (1982). Powers of horror. An essay on abjection. New York: Columbia University Press.

Lang, R., Kett, M., Groce, N. \& Trani, J.-F. (2011). Implementing the United Nations convention on the rights of persons with disabilities: Principles, implications, practice and limitations. ALTER, European Journal of Disability Research, 5(3), 206-220.

Lid, I. M. (2017). Martha C. Nussbaums politiske teori om rettferdighet som bidrag til et teoretisk grunnlag for likeverd og medborgerskap. Fontene Forskning, 10(1), $16-28$.

Lid, I. M. (2013a). Universell utforming. Verdigrunnlag, kunnskap og praksis. Oslo: Cappelen Damm Akademisk. 
Lid, I. M. (2013b). Developing the theoretical content in universal design. Scandinavian Journal of Disability Research, 15(3), 203-215.

Lid, I. M. (2012a). Variasjoner i funksjonsevne som vilkår: En diskusjon av funksjonshemming og menneskesyn i lys av Martha Nussbaums politiske filosofi. Norsk Filosofisk Tidsskrift, 47(2), 130-142.

Lid, I. M. (2012b). Likeverdig tilgjengelighet? En drøfting av menneskesyn og funksjonshemming med vekt på etiske problemstillinger knyttet til universell utforming, mangfold og deltakelse. (Doktoravhandling). Oslo: Det teologiske fakultet, Universitetet i Oslo.

Malterud, K. \& Solvang, P. (2005). Vulnerability as a strength: Why, when, and how? Scandinavian Journal of Public Health, 33(Suppl. 66), 3-6.

Norsk Forbund for Utviklingshemmede (NFU). (2016). Rettighetsutvalgets innstilling. Hentet fra http://www.nfunorge.org/Om-NFU/Nyheter/ Rettighetsutvalgets-innstilling/

Norges Kristne Råd. (2017). Tilvorelsens gave. Kalt til å voere kirke av alle og for alle. Norges Kristne Råds skriftserie, nr. 20. Oslo: Norges Kristne Råd.

NOU 2019: 14 (2019). Tvangsbegrensningsloven — Forslag til felles regler om tvang og inngrep uten samtykke i helse- og omsorgstjenesten. Oslo: Helse- og omsorgsdepartementet.

NOU 2016: 17 (2016). På lik linje. Åtte løft for å realisere grunnleggende rettigheter for personer med utviklingshemming. Oslo: Barne- og familiedepartementet.

Olsen, T., Vedeler, J. S., Eriksen, J., Elvegård, K. (2016). Hatytringer. Resultater fra en studie av funksjonshemmedes erfaringer, NF rapport 6/2016. Bodø: Nordlandsforskning.

Pew Research Center. (2018). Being Christian in Western Europe. Hentet fra http:// www.pewforum.org/2018/05/29/being-christian-in-western-europe

Ramm, J. (2010). På like vilkår? Helse og levekår blant personer med nedsatt funksjonsevne. Statistiske analyser 115. Oslo: Statistisk Sentralbyrå.

Ramm, J. \& Otnes, B. (2013). Personer med nedsatt funksjonsevne. Indikatorer for levekår og likestilling, SSB Rapport 8/2013. Oslo: Statistisk Sentralbyrå.

Regjeringen. (2019). Overleverte Tolga-rapporten til regjeringen. Pressemelding. Hentet fra https://www.regjeringen.no/no/aktuelt/overleverte-tolga-rapportentil-regjeringen/id2628744. [i saken er det tre ulike rapporter fra tre ulike organer]

Regjeringen (2013). Declarations: Article 12; Articles 14 and 25. Hentet fra https:// treaties.un.org/Pages/ViewDetails.aspx?src=TREATY\&mtdsg_no=IV$15 \&$ chapter $=4 \&$ clang $=\_$en

Samarbeidsråd for tros- og livssynssamfunn (STL) / Helsedirektoratet. (2013). Samhandling mellom helse- og omsorgstjenesten i kommunene og tros- og livssynssamfunn. Oslo: STL. 
Sandberg, K. (2015). The convention on the rights of the child and the vulnerability of children. Nordic Journal of International Law, 84(2), 221-247.

Skarstad, K. (2019). Funksjonshemmedes menneskerettigheter. Fra prinsipper til praksis. Oslo: Universitetsforlaget.

Skarstad, K. (2018a). Human rights through the lens of disability. Netherlands Quarterly of Human Rights, 36(1), 24-42.

Skarstad, K. (2018b). Ensuring human rights for persons with intellectual disabilities? Self-determination policies and the use of force in the case of Norway. The International Journal of Human Rights, 22(6), 774-80o.

Statistisk sentralbyrå (SSB). (2018). Funksjonshemmede, arbeidskraftundersøkelsen. Hentet fra https://www.ssb.no/arbeid-og-lonn/statistikker/akutu/aar

Statistisk sentralbyrå (SSB). (2005). Funksjonshemmede, arbeidskraftundersøkelsen, 2004, 2. kvartal. Hentet fra https://www.ssb.no/arbeid-og-lonn/statistikker/akutu/ arkiv/2005-03-01

Stortinget (2018). Representantforslag om utviklingshemmedes rettigheter og likeverd og om tiltak som styrker de grunnleggende rettighetene til mennesker med utviklingshemming, Dokument 8:172 S (2017-2018), Innst. 377 S (20172018). Hentet fra https://www.stortinget.no/no/Saker-og-publikasjoner/Vedtak/ Vedtak/Sak/?p=71682

Lov om endringar i forvaltningslova, tvistelova m.m. (2017). Lov om endringar i forvaltningslova, tvistelova m.m. (overprøvingskompetanse m.m.). (LOV-2017o6-16-63). Hentet fra https://lovdata.no/dokument/LTI/lov/2017-06-16-63

Lov om endringar i kommunelova m.m. (2017). Lov om endringar i kommunelova m.m. (råd for eldre, personar med funksjonsnedsetjing og ungdom). (LOV-2017o6-16-62). Hentet fra https://lovdata.no/dokument/LTI/lov/2017-o6-16-62

Straffeloven. (2008). Lov om straff. LOV-1902-05-22-10. Hentet fra https://lovdata. no/dokument/NL/lov/2005-05-20-28?q=straffeloven

Strand, V. B. \& Ikdahl, I. (2017). Responding to disadvantage and inequality through law. Oslo Law Review, 4(3), 124-132.

Stålsett, S. (2017). Politisk teologi - i ofrenes perspektiv? Godt og ondt i politikken. Kirke og Kultur, 122(3), 248-265.

Syse, A. (2016). Psykisk helsevernloven med kommentarer (3. utg). Oslo: Gyldendal.

Torgauten, T. I. (2016a). Å våge å være en kirke for, med og av alle - del I. Luthersk kirketidende, 151(3), 55-58.

Torgauten, T. I. (2016b). Å våge å være en kirke for, med og av alle - del II. Luthersk kirketidende, 151(4), 85-88.

Tøssebro, J. \& Wendelborg, C. (Red.) (2014). Oppvekst med funksjonshemming. Familie, livsløp og overganger. Oslo: Gyldendal Akademisk. 
Ungdommens Kirkemøte. (2015). UKM 06/15 Ungdomsdiakoni. Hentet fra https:// kirken.no/globalassets/kirken.no/om-kirken/slik-styres-kirken/ungdommenskirkemote/2015/dokumenter/ukm_2015_06_ungdomsdiakoni_vedtak.pdf

UNICEF. (2003). The human rights based approach. Statement of common understanding. Hentet fra https://www.unicef.org/sowco4/files/AnnexB.pdf

Utvalg nedsatt av Bispemøtet. (1997). Veien til prestetjeneste i Den norske kirke. Oslo: Bispemøtet [tilgjengelig via forfatteren].

Vergemålsloven. (2013). Lov om vergemål. (LOV-2019-03-15-6). Hentet fra https:// lovdata.no/dokument/NL/lov/2010-03-26-9?q=vergem\%C3\%A5lsloven

Vårt Land. (2016, 3. mars). Vold mot funksjonshemmede kalles ikke hatkrim. Vårt Land.

Wangen, S. (2017, 28. juni). Rettighetsutvalget støtter regjeringen og forsterker diskrimineringen av utviklingshemmede, Sarpsborg Arbeiderblad.

Wolfrum, R. (2010). Obligation of result versus obligation of conduct: Some thoughts about the implementation of international obligations. I M. H. Arsanjani, J. Cogan, R. D. Sloane \& S. Wiessner (Red.), Looking to the future: Essays on international law in honor of W. Michael Reismann (s. 363-384). Leiden: Martinus Nijhoff.

Ørstavik, S. (2014). Ingenting om oss uten oss (6. november). Hentet fra https:// ldo.no/diskriminert_oldstart/nyheiter-og-fag/om-ombudet/SignertSunniva/ ingenting-om-oss-uten-oss/ 



\title{
KAPITTEL 7
}

\section{Funksjonshemming, bioteknologi og menneskesyn: Utfordringer for kristen etikk}

\section{Gunnar Heiene}

MF vitenskapelig høgskole

\begin{abstract}
The article discusses public attitudes to disabled people in view of recent developments within modern biotechnology, including the new technology called non-invasive prenatal diagnostics (NIPT) that makes it possible to test human fetuses for different genetic disorders. In the critical evaluation of this practice, feminist ethics is utilized. The article discusses the issue of human rights for disabled people and the specific challenges for disability ethics in this context, including the issue of "selective" abortion.
\end{abstract}

Keywords: abortion, biotechnology, Christian bioethics, disability, feminist ethics, human rights, NIPT, prenatal diagnostics

\section{Innledning}

Synet på mennesker med funksjonsnedsettelser har gjennomgått store endringer gjennom historien. Mennesker med funksjonshemminger opplever i dag mer støtte og anerkjennelse enn tilfellet var for bare noen tiår siden. Mennesker med fysiske eller mentale funksjonsnedsettelser blir stadig mer synlige i samfunnet, også ved at de tar aktivt del i samfunnsdebatten. Samtidig har forståelsen av funksjonshemming endret seg gradvis fra en situasjon der de medisinske faktorene var i fokus, til en mer helhetlig tilnærming der de samfunnsmessige rammebetingelser for

Sitering av denne artikkelen: Heiene, G. (2020). Funksjonshemming, bioteknologi og menneskesyn: Utfordringer for kristen etikk. I I. M. Lid \& A. R. Solevåg (Red.), Religiøst medborgerskap: Funksjonshemming, likeverd og menneskesyn (Kap. 7, s. 153-173). Oslo: Cappelen Damm Akademisk. https://doi. org/10.23865/noasp.10o.ch7

Lisens: CC BY-NC-ND 4.0. 
den mangfoldige gruppen av mennesker med funksjonsnedsettelser har fått større oppmerksomhet.

Selv om det generelle bildet viser at funksjonshemmede i dag har flere ressurser og offentlige tilbud til rådighet enn tidligere generasjoner, og at de er blitt mer akseptert og integrert i samfunnet, er det fortsatt mange utfordringer å ta tak i for at samfunnets holdninger til denne gruppen i enda sterkere grad skal preges av inkludering og støtte. Fortsatt gjenstår mye arbeid for å sikre funksjonshemmedes menneskerettigheter og skape et mer inkluderende samfunn der alle er "helt med», slik det formuleres i en av de nyere norske bøkene om dette temaet (Dahle \& Torgauten, 2015).

Det norske samfunnet i dag er preget av det vi med et litt upresist uttrykk kan kalle "den moderne velferdsstaten», der man er opptatt av at alle grupper i samfunnet skal få del i de ressursene som er til rådighet. Kombinasjonen av ny teknologisk kunnskap, økte materielle ressurser og en klar vilje til rettferdig fordeling av disse ressursene har skapt nye utfordringer for synet på mennesker med ulike typer funksjonsnedsettelser. På den ene siden har de økte ressursene muliggjort mer støtte og hjelp til utsatte grupper i samfunnet. På den andre siden har utviklingen innenfor moderne bio- og genteknologi skapt økt bekymring for hvordan denne teknologien kan brukes og misbrukes, på en måte som kan påvirke våre holdninger til funksjonshemmede i negativ retning.

\section{Tema og problemstillinger}

I dette bidraget vil jeg særlig rette søkelyset mot utviklingen innenfor moderne bioteknologi. Mange har et håp om at den økte kunnskapen vi i dag har om bio- og genteknologi, kan bidra til et bedre liv for mange med nedsatt funksjonsevne. Samtidig ser vi en økende bekymring for at de nye teknologiske mulighetene på dette feltet kan føre til negative endringer i synet på funksjonshemming og en forsterket jakt på «det perfekte mennesket». Ofte brukes begrepet «sorteringssamfunnet» som en kritisk betegnelse på en slik mulig utvikling.

Jeg vil derfor drøfte hvordan synspunkter fra nyere teologi og etikk, ikke minst feministisk etikk, som legger vekt på de relasjonelle aspekter 
ved etikken som korrektiv til tradisjonelle etiske paradigmer som pliktog konsekvensetikk, kan bidra til å øke bevisstheten om slike utfordringer og sikre grunnleggende rettigheter for alle mennesker, også for dem som blir født med alvorlige funksjonsnedsettelser. Hvordan skal vi forholde oss til spørsmålet om prenatal diagnostikk gjennom de avanserte genteknologiske metodene som er blitt tilgjengelige i senere år? Dette er spørsmål som i dag drøftes i mange land med ulik lovgivning og ulik praksis.

Jeg vil ut fra dette konsentrere meg om følgende to problemstillinger:

- Hvordan utfordres kristen etikk av moderne bioteknologi i spørsmål som har sammenheng med menneskesynet, og da særlig synet på funksjonshemming?

- Hvordan kan feministisk etikk bidra tilå gi svar på disse utfordringene som ivaretar menneskeverdet for alle, uansett funksjonsnivå?

\section{Bioteknologi - nye muligheter, nye utfordringer}

Både i Norge og i en rekke andre land har debatten om fosterdiagnostikk aktualisert viktige bioetiske spørsmål om hvordan vi bør forholde oss til moderne genteknologiske metoder. I løpet av de senere år er det blitt mulig å få detaljert informasjon om fosteret gjennom en såkalt ikke-invasiv prenatal test (non-invasive prenatal test, NIPT) tidlig i svangerskapet, i god tid før grensen for selvbestemt abort (tolvte uke). De som gjerne vil innføre den nye metoden, har blant annet argumentert med at testen er helt ufarlig for fosteret, i motsetning til tradisjonell fosterdiagnostikk (fostervannsprøve), der det er en viss risiko (cirka 0,5 prosent) for spontanabort. Andre har advart mot de langsiktige samfunnsvirkningene av den nye teknologien, og noen hevder at vi beveger oss stadig mer i retning av «sorteringssamfunnet». Også i det politiske miljøet har bioteknologiske spørsmål skapt debatt, blant annet i forbindelse med regjeringsforhandlingene i vårt land våren 2019. Debatten om NIPT er et godt eksempel på hvordan moderne bioteknologi utfordrer oss til fornyet etisk gjennomtenkning, der synet på funksjonshemming er et sentralt tema (Hofman, 2014; Hofman \& Carson, 2018). 
Spørsmålet om fosterdiagnostikk og om hvem som skal få tilgang til NIPT, har vært grundig drøftet i Bioteknologirådet, der jeg selv var medlem i årene 2014-2019. Spørsmålet kan egne seg som ett av flere eksempler på hvordan moderne bioteknologi kan påvirke synet på funksjonsnedsettelse og arvelige sykdommer. Et viktig tema innenfor funksjonshemmingsteologien er nettopp de etiske utfordringene som henger sammen med utviklingen innenfor nyere bioteknologi, og som aktualiserer hvilke rettigheter mennesker med nedsatt funksjonsevne har i vårt moderne teknologiske samfunn (Asch, 2001; Cahill, 2005; Swinton \& Brock, 2007). Bioetikken trenger åpenbart et funksjonshemmingsperspektiv som kan åpne opp for spørsmål som ikke nødvendigvis fanges opp i diskusjonene om medisinsk teknologi og nye metoder (Kuczevski, 2001). I debatten om prenatal diagnostikk blant representanter for funksjonshemmede er ikke temaet først og fremst om abort kan forsvares i seg selv, men om hvilke signaler som sendes til samfunnet når abort blir tillatt på bakgrunn av bestemte trekk ved fosteret, for eksempel trisomi 21, altså Downs syndrom (Reynolds, 2003; Manninen, 2015). Et liberalt ytterpunkt i debatten er Richard Dawkins (2014), som hevder at det er «umoralsk» ikke å abortere et foster som har Downs syndrom.

Jeg har også en mer personlig grunn til å velge dette temaet, ettersom jeg er far til et barn med alvorlig utviklingshemming. Det er ikke overraskende at mange som er opptatt av funksjonsnedsettelser som akademisk tema, har erfaringer fra eget liv eller familie- og vennekretsen som også har skapt et faglig engasjement på dette området. Vår yngste datter, som er født i 1990, fikk tidlig den generelle diagnosen «alvorlig psykisk utviklingshemming», men utviklingen innenfor bioteknologisk forskning har ført til at hun nå har fått en helt presis diagnose - spontan mutasjon $\mathrm{i}$ et gen med betegnelsen $\mathrm{DDX}_{3} \mathrm{X}$. I august 2015 publiserte et anerkjent amerikansk tidsskrift en rapport om at mutasjoner i dette genet er en årsak til uforklart kognitiv funksjonsnedsettelse hos jenter (Snijders Blok, Madsen, Juusola, Gillisen, Baralle et al., 2015). Metoden som ble brukt, kalles «heleksomsekvensering» og har bare vært tilgjengelig de siste årene. Dette er en undersøkelse der hele «eksomet», det vil si de delene av DNA-molekylet som inneholder oppskrifter på proteiner, blir kartlagt. Frem til nå er det oppdaget cirka 300 tilfeller av denne 
mutasjonen, og det er blitt anslått at den er årsak til mellom 1 og 3 prosent av alle tilfeller av kognitiv funksjonshemming hos jenter, ofte forbundet med ulike fysiske funksjonsnedsettelser.

Denne informasjonen var av stor betydning for oss foreldre. Vi behøvde ikke lenger å spekulere i om utviklingshemmingen kunne ha vært forårsaket av en fødselsskade, og vi kunne også utelukke muligheten for videreføring gjennom arv hos våre tre øvrige barn. I USA er det for øvrig etablert en stiftelse, $\mathrm{DDX}_{3} \mathrm{X}$ Foundation, som tilbyr veiledning og assistanse for familier som er berørt. Vår erfaring er bare ett av mange eksempler på at muligheten for gentesting kan ha en positiv betydning for mennesker med funksjonsnedsettelse (Wright, 2019).

\section{Menneskesyn og funksjonshemming}

Vårt syn på hva mennesket er, og hvilken verdi et menneskeliv bør tilkjennes, blir aktualisert i møte med alle former for funksjonshemming, både fysisk og mentalt. I vår moderne vestlige kultur, som i så stor grad idealiserer det friske, harmoniske og vellykkede mennesket, blir dette spesielt utfordrende. Et typisk uttrykk for vår tids menneskesyn finner vi i Verdens helseorganisasjons (WHO) definisjon av helse som «en tilstand av fullstendig fysisk, mentalt og sosialt velvære og ikke bare fravær av sykdom og lyte»(WHO, Principles). En slik forståelse skaper store problemer i møte med alle former for funksjonshemming, både på grunn av de utopiske elementene i definisjonen, ikke minst begrepet «fullstendig velvære», og fordi det ikke er mulig å finne klare, objektive og universelle kriterier for hva som er god helse. Dette fører lett til at terskelen for hva som blir sett på som helseproblemer og sykdom blir senket, og til at vår evne til å leve med kroniske sykdommer blir svekket (Huber et al., 2011).

I vår tid har forståelsen av funksjonshemming ofte vært preget av en medisinsk modell som har sett på funksjonshemminger som mangler eller svakheter som kan «fikses» gjennom ulike tiltak for de enkeltindivider som avviker fra normalen på grunn av spesielle fysiske kognitive, eller mentale funksjonsnedsettelser. En slik forståelse har selvsagt hjulpet mange mennesker til å få et bedre liv. Imidlertid har den ensidige 
medisinske tilnærmingen ført til at mennesker med funksjonsnedsettelser kan oppleve å bli behandlet som objekter som representerer et avvik eller en mangel, med oppmerksomhet på problemer som må løses for å kunne leve et godt liv.

Innen funksjonshemmingsstudier er den medisinske modellen ofte erstattet av en sosial modell som formidler at den medisinske modellen legger for ensidig vekt på enkeltindivider, på bekostning av de sosiale og strukturelle problemene som møter mennesker med nedsatt funksjonsevne (Oliver, 2013; Campbell \& Beckett, 2015). I 2001 publiserte WHO et internasjonalt klassifikasjonssystem - det såkalte International Classification of Functioning, Disability and Health (ICF) - som la vekt på den gjensidige vekselvirkningen mellom individers helsetilstand (for eksempel cerebral parese eller Downs syndrom) og ulike former for ytre faktorer (negative holdninger, fysiske hindringer og mangel på samfunnsmessig støtte). Dette innebærer at funksjonshemming forstås som en universell menneskelig erfaring som alle kan oppleve i noen grad i faser av livet.

Vi kan altså snakke om et paradigmeskifte innenfor dette feltet de siste 15-20 årene, der de sosiale og relasjonelle aspektene ved funksjonshemming har fått større oppmerksomhet. Dette har åpnet for å forstå funksjonshemmedes situasjon innenfor en større ramme, der både de særegne, individuelle aspektene ved funksjonsnedsettelsen og de sosiale barrierene og hindringene på makronivå blir relevante (Reindal, 2008). I sin doktoravhandling om forståelsen av funksjonshemming hevder Jan Grue (2011) at det ikke er sakssvarende å sette den sosiale og den medisinske modellen opp mot hverandre, men at vi heller må se på forholdet mellom dem i lys av begreper som «interaction» og «interdependence». Begrepet interseksjonalitet er blitt stadig mer vanlig i nyere teori om funksjonshemming (Goethals et al., 2015). Det åpner opp for å kombinere flere perspektiver i forståelsen av funksjonshemming, for eksempel sammenhenger med kjønn, rase og etnisitet (James \& Wu, 2006). Slike endringer i forståelsen av funksjonshemming har hatt stor politisk betydning og har bidratt til frigjøring av funksjonshemmede, ettersom ansvaret for å fjerne hindringer og byrder plasseres hos samfunnet som helhet (Shakespeare, 2010). 
Utviklingen i forståelsen av funksjonshemming gjenspeiler idealer fra den moderne velferdsstaten, som gjennom de siste tiårene har bygd ut et omfattende system av tiltak for å øke mulighetene for handlingsfrihet og livsutfoldelse, også for mennesker med nedsatt funksjonsevne (Andreassen, 2014; Sørvoll, 2015). Kjersti Skarstad (2018a) har drøftet spørsmålet om hvordan vi bedre kan beskytte funksjonshemmedes menneskerettigheter. Blant annet retter hun kritikk mot den norske vergemålsordningen, som hun mener praktiseres på en måte som er problematisk ut fra retten til selvbestemmelse for alle funksjonshemmede, en rett som er nedfelt i FN-konvensjonen om rettighetene til personer med nedsatt funksjonsevne (CRPD) (Skarstad, 2017, 2018b).

Slike perspektiver bør også inkluderes i en teologisk tilnærming til funksjonsnedsettelse. Det er viktig å rette søkelyset mot samfunnets holdninger til funksjonshemmede, og mot de problemer som skapes på grunn av fordommer og negative reaksjoner i ulike sosiale sammenhenger. Utviklingen innenfor moderne bio- og genteknologi gjør det påkrevd å ta disse utfordringene på alvor, slik flere feministiske etikere har bidratt til, både innenfor funksjonshemmingsstudier generelt, som hos Rosemarie Garland-Thomson (2002, 2005), og i møte med moderne bioetikk, med Jackie Leach Scully (2003, 2008, 2018) som en av flere sentrale bidragsytere til feltet «disability bioethics». Et viktig norsk bidrag er Inger Marie Lids doktoravhandling, Likeverdig tilgjengelighet (Lid, 2012), som drøfter menneskesyn og funksjonshemming med vekt på etiske problemstillinger knyttet til «universell utforming, mangfold og deltakelse». Hennes konklusjon er følgende:

Et menneskesyn som vektlegger mennesket som mottakende og anerkjenner kroppslig sårbarhet som allment universelt vilkår, er et godt utgangspunkt for å diskutere inkludering allment sett. Paulus' radikale nytolkning av menneskets kroppslige sårbarhet viser en aksept av de torner i kroppen mennesket lever med, og som tilhører livets grunnvilkår. Hans fortolkning og refleksjon over sårbarheten er viktig for vår tid, som et korrektiv til ideologisering av en perfekt, sterk og veltrent kropp, uten grenser. (Lid, 2012, s. 250) 


\section{Teologisk bioetikk}

Innenfor kristen etikk og teologi har man de siste tiårene vært nødt til å reflektere over utfordringene fra moderne bioteknologi, og det har vært publisert mange bøker og artikler innenfor dette feltet som viser stor bredde, både i synet på konkrete bioetiske spørsmål og i forståelsen av hva som kjennetegner kristen bioetikk.

Den kjente kristne bioetikeren H. Tristham Engelhardt Jr., mangeårig redaktør av tidsskriftet Christian Bioethics, skrev for noen år siden en kritisk artikkel der han gikk til frontalangrep på store deler av den kristne bioetikken de siste 50-60 årene (Engelhardt Jr., 2014). Han rettet sterk kritikk mot pionerer som Paul Ramsey og Richard McCormick, som begge spilte viktige roller i diskusjoner om bioteknologi og helsespørsmål i USA fra 1960-tallet. Engelhardt Jr. hevdet at deres bidrag førte til en utvanning av det kristne grunnlaget for bioetikken på grunn av ønsket om å argumentere allment, uten eksplisitte henvisninger til kristne perspektiver. Han støttet seg særlig til den kjente teologen og etikeren Stanley Hauerwas, som allerede i det første nummeret av Christian Bioethics gikk til angrep på denne tradisjonen, som han mente sviktet når det gjaldt å utforme en autentisk kristen bioetikk (Hauerwas, 1995). Hauerwas representerer en tradisjon i kristen etikk der man ikke er opptatt av å argumentere ut fra en felles allmennmoralsk erkjennelse, eller av å utforme etiske synspunkter som kan danne grunnlaget for samfunnets politikk og lovgivning. Her målbærer han en annen oppfatning enn den som har preget norsk teologi og etikk de siste tiårene, der kirkens og den kristne etikkens positive bidrag til samfunnsdebatten, også i bioetiske spørsmål, har vært understreket, med en åpenhet for å kombinere allmenne og spesifikt kristne argumenter.

En viktig bidragsyter til teologisk bioetikk er katolikken Lisa Sowle Cahill, både gjennom boken Theological Bioethics (Cahill, 2005) og andre sentrale bidrag (Cahill, 2003, 2014). Hennes hovedanliggende er at kristen bioetikk må fremme rettferdighet og lik tilgang til helse- og omsorgsressurser, også i et globalt perspektiv. Hun understreker at bioetikk i det 21. århundre ikke bare handler om individuelle moralske valg, men først og fremst må forstås som sosialetikk, ikke bare i teorien, men også i praktisk engasjement. Hun henter støtte for en slik oppfatning i 
både frigjøringsteologien og katolsk sosiallære (Cahill, 2005, s. 4-5). I en kulturell situasjon der sekulariseringen har ført til at religionens rolle er svekket, både i den akademiske verdenen og i media, må teologisk bioetikk aktivt inn i samfunnsdebatten, hevder hun (s. 51). Et viktig norsk bidrag i senere år er boken Menneskeverd i klinikk og politikk. Bioetikk $i$ lys av kristen tro (Magelssen, 2013).

\section{Sorteringssamfunnet}

En av grunnene til at mange kristne etikere og kirkesamfunn i senere år har engasjert seg i bioetiske spørsmål, er de åpenbare utfordringene som kommer til syne når det gjelder oppfatningen av mennesker med funksjonsnedsettelser. De færreste går så langt som filosofen Peter Singer, som har hevdet at det å ta livet av et nyfødt barn med «defekter» i mange tilfeller ikke er moralsk galt i det hele tatt (Singer, 2011, s. 167). Men det er likevel grunn til å være på vakt mot en utvikling i retning av mindre vern for enkelte grupper av mennesker, begrunnet ut fra et «lavere» funksjonsnivå.

Både i Norge og en rekke andre land har kristne teologer og etikere engasjert seg i kampen mot «sorteringssamfunnet», forstått som et samfunn der moderne bioteknologi blir utnyttet til i størst mulig grad å unngå at det fødes barn med nedsatt funksjonsevne. I boken Uønsket har politikeren Erik Lunde (2017, s. 29) i tilslutning til medisineren Morten Magelssen (2013, s. 66) gitt følgende definisjon av dette begrepet: «Et samfunn som tillater tilsiktet og systematisk sortering av mennesker med bestemte egenskaper, kan vi kalle et sorteringssamfunn.» Lunde trekker blant annet frem Richard Dawkins' påstand om at det kan være umoralsk å bære frem et barn med Downs syndrom, og han hevder at en slik oppfatning bygger på en klassisk utilitaristisk logikk. Han viser også til følgende sitat av Aksel Braanen Sterri: «De som har Downs, vil aldri kunne leve fullverdige liv, uansett hvor mye vi som samfunn legger til rette for det» (Lunde, s. 233; jf. Sterri, 2014).

I denne debatten er det viktig at vi ikke bare retter søkelyset mot den enkelte kvinnes eller families valg, men også mot de rammebetingelsene som finnes for familier med funksjonshemmede barn (Lein, 2018). Et 
eksempel på dette er et innlegg av Anne Holt (2018) i debatten om sorteringssamfunnet, der hun blant annet skriver følgende:

Selvsagt ønsker ikke tilhengerne av dagens abortlov noe sorteringssamfunn. Dessverre er et slikt samfunn imidlertid allerede her, om enn ganske så post-natalt. Nærmest ukentlig, året rundt, leser og hører vi vitnesbyrd om hvilken alvorlig byrde sterkt funksjonshemmede barn er for sine foreldre og søsken. Vi erfarer at de ikke får den hjelpen de trenger, det skjæres og kuttes i bevillinger og budsjetter på en måte som definitivt bidrar til å sortere ut enkeltfamilier til langt dårligere livsvilkår enn oss andre. Familier går i stykker, søsken lider, og særlig kvinners karrierer går i vasken for livet. Dette er sortering, slik det også sorteres på en rekke andre områder. Sorteringssamfunnet har vi hatt siden tidenes morgen, og vi er alle ansvarlige.

Spørsmålet om etiske vurderinger av reproduktive valg står sentralt i dagens bioetiske debatt, men dette er ikke det eneste temaet når vi arbeider med forholdet mellom funksjonshemming og bioetikk. Det blir sterkt understreket av Jackie Leach Scully, som tar til orde for et utvidet perspektiv basert på endringene i forståelsen av funksjonshemming. Hun hevder at funksjonshemmingsstudier må ha et perspektiv som går ut over (selv om de ikke utelukker) den biomedisinske forståelsen av funksjonshemming. Scully refererer til en formulering av Simi Linton, en pioner innenfor dette fagfeltet. Ifølge Linton tilfører funksjonshemmingsstudier en kritisk dimensjon til tenkningen om spørsmål som autonomi, kompetanse, helhet, avhengighet og uavhengighet, helse, fysisk fremtreden, estetikk, fellesskap og ideer om fremskritt og fullkommengjøring, altså spørsmål som berører alle sider ved våre liv, og som også angår bioetikken (Scully 2008, s. 3; Linton 1998, s. 218).

Scully skiller videre mellom to ulike måter å tematisere funksjonshemming i etikken på - «ethics of disability» og «disability ethics» (Scully, 2008, s. 9). Mens det første begrepet dreier seg om den systematiske refleksjonen over moralsk akseptable måter å forholde seg til funksjonshemmede mennesker på, handler det andre om de bestemte moralske forståelsene som genereres gjennom erfaring av funksjonshemming. Begge disse tilnærmingene er nødvendige for å få en helhetlig forståelse. 


\section{Feministisk bioetikk}

Jackie Leach Scully har ikke bare tematisert behovet for en etikk om funksjonshemming. Hun har også understreket feminismens betydning for bioetikken. Hun hevder at det foreligger en erkjennelsesmessig urettferdighet («epistemic injustice») som består i at kunnskap hos utsatte grupper, for eksempel funksjonshemmede, ikke blir inkludert i våre kollektive erkjennelsesmessige ressurser (Scully, 2018, s. 106).

Scully er ikke det eneste eksemplet på feministiske etikere som har lagt spesiell vekt på utfordringene innenfor spenningsfeltet bioteknologi og funksjonshemming gjennom de siste 10-15 år. Også Garland-Thomson har berørt dette temaet i flere sammenhenger (Garland-Thomson, 2002, 2005). Et annet eksempel er den finske feministiske etikeren Eeva Nyrövaara (2011), som retter et kritisk søkelys mot moderne stamcelleforskning. Hun legger vekt på at en feministisk oppfatning av autonomi og handling bryter med oppfatningen om det fullstendig autonome subjektet, og hun understreker at menneskets individualitet blir definert ved relasjonalitet, altså at vi er forbundet med andre. Derfor blir våre valg i stor grad formet av den samfunnsmessige konteksten og kulturelle verdier: Våre moralske handlinger blir formet i et nettverk av «oppression, subordination, and power» (Nyrövaara, 2011, s. 213). Utgangspunktet i det kontekstuelle fører til at bioetikken må unngå en for sterk betoning av det autonome, uavhengige subjektet. I stedet mener Nyrövaara at vi må vektlegge «connectivity», vår forbindelse med andre mennesker, som det grunnleggende perspektivet på mennesket.

Selv om Nyrövaara ikke primært er opptatt av temaet funksjonshemming, peker hennes feministiske antropologi i samme retning som mange nyere bidrag innenfor funksjonshemmingsstudier. Dette gjelder blant annet Barbara E. Gibsons artikkel «Disability, connectivity and transgressing the autonomous body» (2006). Her blir sammenhengene mellom funksjonshemming, teknologi og miljø tematisert, og vestlige oppfatninger av det uavhengige, autonome subjektet blir kritisert. Vår tids diskurs om uavhengighet blir anklaget for å bidra til å marginalisere kropper som stemples som funksjonshemmet. Alternativt kan funksjonshemming oppfattes som en mulighet til å utvide 
forståelsen av subjektivitet og lede i retning av en radikalt ny etikk som ikke bare er basert på individuelle rettigheter, hevder Gibson. Mye taler for at feministisk etikk, med sin vekt på betydningen av relasjoner og kontekst, er bedre egnet enn tradisjonell vestlig etikk av typen plikt- eller konsekvensetikk når vi drøfter vanskelige bioetiske spørsmål.

\section{Menneskerettigheter for personer med funksjonsnedsettelse}

Temaet funksjonshemming og bioetikk aktualiserer viktige spørsmål om funksjonshemmedes menneskerettigheter, blant annet når det gjelder spørsmål om liv og død, helse, behandling og autonomi. Bakgrunnen for at slike spørsmål er blitt satt på dagsordenen i tiden etter andre verdenskrig, er blant annet de mange overgrepene mot funksjonshemmede som fant sted i Nazi-Tyskland før og under krigen. Dette har ført til at enkelte også har brukt begrepet «eugenikk» om de nye mulighetene innenfor moderne bioteknologi, som preimplantasjonsdiagnostikk (pre-implantation genetic diagnosis, PGD) og prenatal diagnostikk (Wilkinson, 2009). Men det finnes også mange eksempler fra både USA og andre land på at personer med funksjonsnedsettelser og andre sårbare grupper har vært utnyttet i medisinsk forskning uten at de har hatt anledning til å gi informert samtykke.

En av dem som har engasjert seg mest i dette temaet, er Adrienne Asch (1946-2013), som selv var blind, og som har publisert en rekke bøker og artikler om menneskerettslige utfordringer ved moderne bioetikk. Hun har pekt på likhetstrekk mellom viktige anliggender i bioetikken og i vår tids internasjonale bevegelse for funksjonshemmedes menneskerettigheter, særlig slik de kommer til uttrykk i sosiale og minoritetsbaserte modeller (Asch, 2001). Det dreier seg ikke bare om enkeltindividers valg, men om hvordan ny forskning har frembrakt hittil ukjente muligheter som vi må ta stilling til ut fra etiske normer. Spørsmålet er ikke lenger bare om et menneskeliv kan reddes, men om det $b ø r$ reddes. Definisjoner av «helse», «normalitet», «funksjonshemming» og «livskvalitet» skaper ofte kontroverser fordi det ikke finnes 
klare, objektive og universelle definisjoner av slike begreper. Ikke minst har helse vært definert på mange ulike måter.

En ensidig medisinsk forståelse av funksjonshemming kan gi grunnlag for misoppfatninger som henger sammen med at funksjonshemming betraktes isolert, som en nødvendig konsekvens av biologiske begrensninger. Når en person med funksjonsnedsettelse erfarer isolasjon, maktesløshet, fattigdom, arbeidsløshet eller lav sosial status, blir dette forstått som uunngåelige følger av biologiske begrensninger. Det fører til at viktige perspektiver blir utelatt fra synsfeltet, ikke minst samfunnets manglende evne til å tilpasse seg ulike evner og måter å fremtre på i verden. Det å leve med funksjonshemming er ikke nødvendigvis en tragedie, slik det ofte fremstilles i medisinsk og bioetisk litteratur. Problemet ligger heller i den sosiale, institusjonelle og fysiske verdenen, som ikke er tilpasset funksjonshemmedes behov.

Som alternativ til en slik stereotyp forståelse av funksjonshemming peker Asch på muligheten for å akseptere at «disability is a fact of human life», og at vi er tjent med at samfunnet legger til rette for at alle mennesker, uansett funksjonsnivå, kan delta meningsfylt i den sosiale og fysiske verdenen med de evner og muligheter de besitter (Asch, 2001, s. 64; jf. Asch, Jeffries \& Taylor, 2008).

\section{Prenatal diagnostikk - etiske utfordringer}

Asch ser alvorlige etiske problemer forbundet med vår tids fokus på prenatal diagnostikk, og hun har publisert flere viktige bidrag om dette temaet ut fra et funksjonshemmingsperspektiv, både alene og sammen med Erik Parens. Ikke minst er hun opptatt av å få frem forskjellen mellom medisinske og sosiale paradigmer for funksjonshemming. Hun peker på at det ikke finnes klare, objektive og universelle definisjoner av begreper som «helse», «normalitet» og «funksjonshemming». Særlig retter hun kritikk mot den «medisinske» modellen, som hun hevder bygger på feilaktige antakelser med alvorlige konsekvenser, nemlig forestillingen om at livet er ødelagt («disrupted») for alltid for en person med kronisk sykdom eller funksjonsnedsettelser, mens det å brekke en fot eller å få lungebetennelse kan utløse en midlertidig krise som normalt vil gå over. I virkeligheten, 
hevder hun, er situasjonen den at de fleste mennesker med tilstander som spina bifida, akondroplasi (kortvoksthet), Downs syndrom og mange andre funksjonsnedsettelser, oppfatter seg selv som friske, ikke syke, og beskriver sine tilstander som gitte størrelser i livet («the equipment with which they meet the world») (Asch, 1999, s. 1651).

I boken Prenatal Testing and Disability Rights (Parens \& Asch, 2000), blir kritikken mot fosterdiagnostikk fra forskere som også har erfaring med funksjonsnedsettelse, formulert av Marsha Saxton (2000) gjennom følgende spørsmål:

- Hvorfor reagerer så mange funksjonshemmede aktivister så negativt på prenatal diagnosikk og selektiv abort, når den samme gruppen som regel er for fri abort?

- Sender prenatal diagnostikk et budskap til mennesker med funksjonsnedsettelser (og til offentligheten generelt) som forsterker eller opprettholder diskriminering?

- Hva blir egentlig kommunisert gjennom tilgangen til prenatal diagnostikk og selektiv abort av dem som skriver ut fra et rettighetsperspektiv?

Den australske bioetikeren Lynn Gillam (1999) har levert en nyansert drøfting av disse spørsmålene. Hennes utgangspunkt er kritikken som går ut på at prenatal diagnostikk for å avdekke genetiske eller andre typer unormale tilstander hos fosteret, er en form for diskriminering. Her tar hun utgangspunkt $\mathrm{i}$ en formulering fra en britisk talskvinne for funksjonshemmedes rettigheter, Alison Davis, som sa: «In the specific case of women with disabilities, and the rights of handicapped people as a whole, it is becoming ever more obvious that the 'right' to abortion is denying us our very right to exist» (1987, s. 276). Davis hevder også at de nye genteknologiske metodene, inkludert prenatal diagnostikk, i bunn og grunn er en teknologi for undertrykkelse og kontroll som devaluerer livene til dem som identifiseres seg som funksjonshemmet.

Gillams bidrag er verdifullt fordi det bygger bro mellom de to tradisjonelle fløyene i denne debatten. Hun avviser en ensidig medisinsk modell for å forstå funksjonshemming og hevder at funksjonshemming i en viss 
utstrekning er sosialt konstruert. Dette innebærer at både fysiske og kognitive funksjonsnedsettelser blir forsterket gjennom den måten samfunnet påvirker den enkelte på. Imidlertid avviser hun en rendyrket sosial modell, ettersom det finnes både genetiske og andre betingelser som vil føre til begrensning og lidelse uansett sosial setting.

En mulig konsekvens av økt tilgang til prenatal diagnostikk kan være at antallet mennesker som lever med funksjonsnedsettelser, vil bli betydelig redusert. Det foreligger klare indikasjoner på at det store flertallet kvinner vil velge å avbryte et svangerskap som svar på tilstander som trisomi 13, 18 eller 21, Tay-Sachs og andre mer eller mindre alvorlige diagnoser hos fosteret (Gillam, 1999; jf. Wertz \& Fletcher, 1999). I mange vestlige land har utbredelsen av negative og diskriminerende holdninger til mennesker med funksjonsnedsettelser avtatt i betydelig grad de siste tiårene, og funksjonshemmedes rett til å delta i samfunnet på lik linje med andre borgere har gradvis blitt mer selvsagt. Når prenatal diagnostikk og selektiv abort blir rutine, kan det ifølge Gillam øke risikoen for at samfunnets holdninger til denne gruppen endrer seg. Før prenatal diagnostikk ble vanlig, var det å få et barn med funksjonsnedsettelse uforutsigbart og uunngålig. Med de nye teknologiske mulighetene blir det i stadig større grad et bevisst valg fra foreldrenes side som avgjør om barnet skal bæres frem eller aborteres. Foreldre som ikke vil avbryte svangerskapet eller gå igjennom prenatal testing, kan da bli sett på som uansvarlige eller hensynsløse. Slike holdningsendringer kan i sin tur føre til økt diskriminering av mennesker med funksjonsnedsettelser, fordi de kan bli oppfattet som en byrde for samfunnet og stå i fare for å bli sosialt marginalisert. En videre konsekvens kan være nedgang i offentlige støtteordninger og utvikling av fiendtlige samfunnsmessige holdninger. Slike utviklingstrekk vil også kunne sende klare meldinger til dem som i dag lever med funksjonsnedsettelser, om at andre ser på deres liv som ulykkelig, uproduktivt og uønsket.

Gillam understreker at dette ikke nødvendigvis betyr at de som tilbyr prenatal diagnostikk eller benytter seg av tilbudet, selv står for eller ønsker å kommunisere slike holdninger. Derfor er det ikke nok å argumentere med at prenatal diagnostikk bare gir foreldrene mulighet til å velge, og at det ikke innebærer noen negativ oppfatning om funksjonshemming. 
Det er ingen tvil om at dersom terminering blir standardsvaret når man oppdager noe unormalt hos et foster, vil mennesker med funksjonsnedsettelser tolke det som en indikasjon på at både legene og samfunnet som helhet mener at det ville være bedre om funksjonshemmede barn ikke ble født. Et slikt budskap vil virke demoraliserende for dem som lever med funksjonsnedsettelser. Gillam siterer Deborah Kaplan (1989), en kjent talskvinne for personer med funksjonsnedsettelser, som hevder at det må være mulig å snakke om forsterdiagnostikk uten å forutsette at funksjonshemming alltid og for alle mennesker er tragisk, smertefullt og byrdefullt. (Gillam, 1999, s. 166). For at prenatal diagnostikk ikke skal bidra til å forsterke negative holdninger til funksjonshemmede, trengs tiltak for å bedre samfunnets holdninger til funksjonshemmede og $ø$ ke støtten til denne gruppen. Men hun legger ikke skjul på at dette er krevende:

So whilst it is in theory correct to say that prenatal diagnosis and selective abortion will not inevitably lead to increased intolerance of people with disabilities, there are dangers of negative social outcomes, which needs to be recognized and combated. (s. 166-7)

Gillam drøfter også et annet argument i denne debatten, som ikke tar utgangspunkt i empiriske data om konsekvenser for synet på funksjonshemmede, men som beveger seg på begrepsnivå og hevder at selektiv abort som begrep i seg selv fører til diskriminering av funksjonshemmede. Ofte blir abort forsvart som en mulig løsning der fosteret tilkjennes lav moralsk status, ut fra følgende argumenter: (1) til beste for det kommende barnet (2) sammenlikning med et fremtidig barn uten funksjonsnedsettelser og (3) til beste for den blivende mor (s. 167).

Gillams anliggende er ikke å drøfte selektiv abort som etisk tema i og for seg, men hvorvidt argumentene som brukes for å forsvare selektiv abort, innebærer diskriminering av funksjonshemmede. På den ene siden mener hun at en konstatering av lav livskvalitet ikke i seg selv innebærer en moralsk vurdering eller diskriminering. På den andre siden peker hun på at det vanligste, når vi konstaterer at mennesker har lav livskvalitet, er å svare med å gi hjelp og støtte, slik for eksempel medisinsk personell gjør i behandling av syke og lidende pasienter. Derfor må vi skjelne mellom 
moralsk nøytrale oppfatninger om livskvalitet og moralske dommer som potensielt kan være diskriminerende (s. 169).

Det viktigste spørsmålet er ikke hvordan vi oppfatter livskvaliteten til funksjonshemmede, men hva vi bruker denne oppfatningen til. Argumenter ut fra et syn som gir fosteret lavere moralsk status enn en person som er født, og argumenter ut fra livskvalitet som gir adgang til å ta livet av fostre med indikasjoner for medisinske diagnoser eller genetiske variasjoner, kan ikke brukes til å diskriminere mennesker med funksjonsnedsettelser. Imidlertid vil mennesker med funksjonsnedsettelser berøres av at mennesker rundt dem vurderer deres situasjon og livskvalitet, og ofte vil de oppleve at andre har en mye mer negativ oppfatning av dem enn de selv har. Det verste eksemplet på dette er ifølge Gillam når argumentet om at det er til det beste for det kommende barnet brukes til å forsvare selektiv abort, ut fra tanken om at barnet ville være «better off dead than disabled» (s. 170).

Gillam konkluderer med at diskriminering av mennesker med funksjonsnedsettelser verken er en følge av eller en nødvendig, integrert del av prenatal diagnostikk. Men hun medgir at prenatal diagnostikk har et potensial for signifikante negative virkninger for mennesker med funksjonsnedsettelser, og at disse sidene ved den nye teknologien må tas på alvor ut fra en sterk etisk bevissthet. Dette standpunktet er uttrykk for en vanskelig, men nødvendig balansegang mellom en ukritisk optimisme eller en ensidig pessimisme i synet på moderne medisinsk teknologi.

\section{Oppsummering}

Moderne bioteknologi påvirker uten tvil vår måte å forstå funksjonshemming på og våre valg innenfor områder som reproduksjon, abort og medisinsk behandling. Dette er en utfordring som møter oss når vi beveger oss innenfor dette feltet, og som aktualiserer hvilken påvirkning vårt menneskesyn har for våre etiske valg. I debatter om «sorteringssamfunnet» er det viktig å gjennomtenke argumentasjonen for de ulike standpunktene. Nærkontakt med mennesker som har funksjonsnedsettelser, vil på den ene siden kunne gi forståelse for ønsket om å sikre størst mulig sjanse for at alle skal kunne leve et meningsfylt og menneskeverdig 
liv, uansett funksjonsnivå og egenskaper. På den andre siden kan alle de vansker og utfordringer som møter mennesker med nedsatt funksjonsnivå $i$ vårt samfunn, forklare hvorfor mange er opptatt av å få vite om et kommende barn er friskt eller har en funksjonsnedsettelse. I en slik situasjon er det viktig at noen er talspersoner for det ufødte liv, uansett funksjonsnivå, og at samfunnet legger til rette for at mennesker med nedsatt funksjonsevne kan få leve fullverdige liv med gode rammebetingelser og tilstrekkelig omsorg og bistand. Feministisk etikk kan bidra til å gi oss et menneskesyn og en forståelse av funksjonshemming som fremhever betydningen av å beskytte det sårbare og skjøre livet, som er utsatt for mange trusler i vårt moderne, teknologiske samfunn. Vi blir alle utfordret til å bidra til et samfunn der det ukrenkelige menneskeverdet danner grunnlaget for et fellesskap der alle er regnet med (Heiene, 2015). Det er en utfordring til oss alle, uavhengig av om vi er personlig berørt av funksjonshemming eller ikke. Kampen for det ufødte liv har stått sterkt i kristne miljøer i Norge, men det er også viktig at vi engasjerer oss for dem som lever liv som er litt annerledes på grunn av fysiske eller kognitive funksjonsnedsettelser. Vi trenger en politikk og en samfunnsutvikling som gjør det mulig - og synlig - at alle kan få et godt liv, uansett funksjonsnivå.

\section{Referanser}

Andreassen, T. A. (2014). Brukermedvirkning, politikk og velferdsstat.

(Doktoravhandling). Oslo: Arbeidsforskningsinstituttet.

Asch, A. (1999). Prenatal diagnosis and selective abortion: A challenge to practice and policy. American Journal of Public Health, 89(11), 1649-1657.

Asch, A. (2001). Disability, bioethics, and human rights. I G. Albrecht, K. Seelman \& M. Bury (Red.), Handbook of disability studies (kap. 12). Los Angeles, CA: SAGE Publications.

Asch, A., Jefferies, T., \& Taylor, J. (Red.). (2008). Prenatal testing. I The Boston Women's Health Group, Our bodies, ourselves: Pregnancy and birth (s. 109-127). New York, NY: Touchstone.

Bioteknologirådet. (2015, 13. august). Fosterdiagnostikk. Hentet fra http://www. bioteknologiradet.no/

Bioteknologirådet. (2016, 4. august). Fosterdiagnostikk: NIPT for å undersøke trisomi hos fosteret. Hentet fra http://www.bioteknologiradet.no/ 
Bioteknologirådet. (2017, 9. februar). Ikke-invasiv prenatal testing (NIPT) for kjønnsbestemmelse av foster ved risiko for alvorlig kjønnsbundet sykdom. Hentet fra http://www.bioteknologiradet.no/

Bioteknologirådet. (2017, 20. september). Bruk av NIPD ved risiko for alvorlig, arvelig sykdom. Hentet fra http://www.bioteknologiradet.no/

Cahill, L. S. (2003). Bioethics, theology, and social change. Journal of Religious Ethics, 31(3), 363-398.

Cahill, L. S. (2005). Theological bioethics: Participation, justice, and change. Washington DC: Georgetown University Press.

Cahill, L. S. (2014). Bioethics and the common good. Milwaukee, WI: Marquette University Press.

Campbell, T. \& Beckett, A. (2015). The social model of disability as oppositional device. Disability and Society, 30(2) 270-283.

Dahle, S. \& Torgauten, T. I. (Red.) (2015). Helt med! I samme fellesskap uavhengig av funksjonsevne. Oslo: Gyldendal Akademisk.

Engelhardt Jr., H. T. (2014). The recent history of Christian bioethics critically reassessed. Christian Bioethics, 20(2), 146-167.

Garland-Thomson, R. (2002). Integrating disability, transforming feminist theory. NWSA Journal, 14(3), 1-32.

Garland-Thomson, R. (2005). Feminist disability studies. Signs: Journals of Women in Cultures and Society, 3o(2), 1557-1587.

Gibson, B. E. (2006). Disability, connectivity and transgressing the autonomous body. Journal of Medical Humanities, 27(3), s. 187-196.

Gillam, L, (1999). Prenatal diagnosis and discrimination against the disabled. Journal of Medical Ethics, 25, 163-171.

Grue, J. (2011). Interdependent discourses of disability: A critical analysis of the social/medical model dichotomy. (Doktoravhandling). Oslo: Det humanistiske fakultet, Universitetet i Oslo. Hentet fra https://www.duo.uio.no/handle/10852/ 26291

Hauerwas, S. (1995). How Christian ethics became medical ethics: The case of Paul Ramsey. Christian Bioethics, 1, 11-28.

Heiene, G. (2015). Menneskesynet som basis for et fellesskap for alle. I S. Dahle \& T. I. Torgauten (Red.), Helt med! I samme fellesskap uavhengig av funksjonsevne (s. 55-65). Oslo: Gyldendal.

Hofmann, B. (2014). Etiske utfordringer med non-invasive prenatale tester (NIPT). Etikk i Praksis. Nordic Journal of Applied Ethics, 8(1), 67-87.

Hofmann, B. \& Carson, S. G. (2018). Filosofiens rolle i det offentlige ordskiftet: Hvordan har debatten om sorteringssamfunnet i 2017 påvirket forholdet mellom filosofi og samfunn? En innholdsanalyse. Etikk i praksis. Nordic Journal of Applied Ethics, 12(2), 87-103. 
Holt, A. (2018, 9. november). Ordet «sorteringssamfunnet» er blant de mest stigmatiserende og misvisende begreper jeg kan komme på. VG. Hentet fra https://www.vg.no/nyheter/meninger/i/bKPMzk/anne-holt-om-abortdebattenordet-sorteringssamfunnet-er-blant-de-mest-stigmatiserende-og-misvisendebegreper-jeg-kan-komme-paa

Lein, A. (2018, 19. november). Kampen mot sorterings-samfunnet skjer ikke i livmoren. Hentet 21.1.2019 fra https://www.dagbladet.no/kultur/kampen-motsorterings-samfunnet-skjer-ikke-i-livmoren/70465392

Lid, I. M. (2012). Likeverdig tilgjengelighet? En drøfting av menneskesyn og funksjonshemming med vekt på etiske problemstillinger knyttet til universell utforming, mangfold og deltakelse. (Doktoravhandling). Oslo: Det teologiske fakultet, Universitetet i Oslo.

Linton, S. (1998). Claiming disability: Knowledge and identity, New York: New York University Press.

Lunde, E. (2017). Uønsket. Mennesket $i$ sorteringens tid, Oslo: Vårt Land forlag.

Magelssen, M. (2013). Menneskeverd i klinikk og politikk. Bioetikk i lys av kristen tro. Oslo: Lunde forlag.

Nyrövaara, E. (2011). The feminist transformation of bioethics: An analysis of theoretical perspectives and practical applications in feminist bioethics.

(Doktoravhandling). Helsinki: University of Helsinki.

Oliver, M. (1990). The individual and social models of disability. https://disabilitystudies.leeds.ac.uk/wp-content/uploads/sites/4o/library/Oliver-in-soc-dis.pdf

Parens, E. \& Asch, A. (Red.) (200o). Prenatal testing and disability rights. Washington, DC: Georgetown University Press.

Saxton, M. (2000). A disability critique: Why members of the disability community oppose prenatal diagnosis and selective abortion. I E. Parens \& A. Asch (Red.), Prenatal testing and disability rights (s. 147-164). Washington, DC: Georgetown University Press.

Scully, J. L. (2003). Drawing lines, crossing lines: Ethics and the challenge of disabled embodiment. Feminist Theology, 11(3), 266.

Scully, J. L. (2008). Disability bioethics: Moral bodies, moral difference. Lanham, MD: Rowman \& Littlefield.

Scully, J. L. (2018). From 'She would say that, wouldn't she?' to 'does she take sugar?' Epistemic injustice and disability. IJFAB: International Journal of Feminist Approaches to Bioethics, 11(1), 106-124.

Shakespeare, T. (2010). The social model of disability. I L. J. Davis (Red.), The disability studies reader (s. 266-273). New York: Routledge.

Skarstad, K. (2017, 17. november). Vergemålsordning på kollisjonskurs med menneskerettighetene. Dagbladet. 
Skarstad, K. (2018a). Realising the human rights of persons with disabilities. From political ideals to political practices. (Doktoravhandling). Oslo: Universitetet i Oslo.

Skarstad, K. (2018b). Ensuring human rights for persons with intellectual disabilities? Self-determination policies and the use of force in the case of Norway. International Journal of Human Rights, 22(6), 774-80o. https://doi.org/10.1080/13642987.2018. 1454903

Snijders Blok, L. S., Madsen, E., Juusola, J. Gillisen, C., Baralle, D., Reijnders, M. R. et al. (2015, 6. august). Mutations in $\mathrm{DDX}_{3} \mathrm{X}$ are a common cause of unexplained intellectual disability with gender-specific effects on wnt signaling. The American Journal of Human Genetics, 97(6), 343-352.

Sørvoll, J., (2015). The Norwegian welfare state 2005-2015: Public attitudes, political debates and future challenges. Hentet fra https://www.semanticscholar.org/paper/ The-Norwegian-Welfare-State-2005-2015\%3A-Public-and-S\%C3\%B8rvoll-Stolten berg\%E2\%80\%99s/8df6490a26adfd29ebda64a6b5dce7d21a378da5

Wertz, D. C \& Fletcher, J. C. (1999). Feminist criticism of prenatal diagnosis: A response. Clinical Obsterics and Gynaecology, 36(3).

WHO. (u.å.). International classification of functioning, disability and health. Hentet fra http://www.who.int/classifications/icf/en/

Wilkinson, S. (2009, juni). Eugenics talk' and the language of bioethics. Journal of Medical Ethics, 34(6), 467-471. 



\title{
$\AA$ A fortelje eller bli fortalt: Ein analyse av Olaug Nilssens Tung tids tale (2017)
}

\author{
Nora Simonhjell \\ Universitetet i Agder
}

\begin{abstract}
This article focuses on the Norwegian author Olaug Nilssens' novel, Tung tids tale (2017). The novel is based on her experiences with her son who gradually grew autistic from the age of three. Until then he was an active communicating young boy, but gradually his ability to speak and communicate diminished. On a background of theories concerning the use of literature, and vulnerability theory, the literary close reading focuses on the narrative as well as the ethical dilemmas Nilssen and the first-person narrator find herself in. In this moment of crisis, she is crying out to the healthcare system and institutions for more help for herself, her son and the rest of the family. By focusing on both the affective, intimate and structural side of their situation, Nilssen's novel is highly political.
\end{abstract}

Keywords: autism, the use of literature, vulnerability, ethics

\section{Innleiing ${ }^{1}$}

Kva kan ein roman fortelje oss om synet på menneskeverd, funksjonsvariasjon og likeverd? Tung tids tale (Nilssen, 2017) er ein roman som handlar om ei mors kamp for ein autistisk son. Olaug Nilssen skriv om

1 Eg vil takke masterstudentane på emnet «NO 403 Sår og sårbarheter» ved Universitetet i Agder hausten 2018. Diskusjonane med dei har hatt stor tyding for korleis eg tenkjer kring romanen. Eg vil samstundes få takke kollegaer ved Nettverk for tverrfaglig kjønnsforskning og forskingsgruppa Profesjonelle relasjoner i velferdsyrker, begge ved Universitetet i Stavanger, for høvet til å dra på eit skriveopphald under arbeidet med denne artikkelen.

Sitering av denne artikkelen: Simonhjell, N. (2020). Å fortelje eller bli fortalt: Ein analyse av Olaug Nilssens Tung tids tale (2017). I I. M. Lid \& A. R. Solevåg (Red.), Religiøst medborgerskap: Funksjonshemming, likeverd og menneskesyn (Kap. 8, s. 175-192). Oslo: Cappelen Damm Akademisk. https://doi. org/10.23865/noasp.10o.ch8 Lisens: CC BY-NC-ND 4.0. 
smerta og frustrasjonen som dette fører med seg. Ho skriv om kampen ho dagleg kjempar for at sonen skal kunne ha det så bra som det er mogleg at han skal kunne få leve i omgjevnader som passar til den måten han er i verda på, og at han skal få respekt for kven han er. Dette er ein kamp som på den eine sida går føre seg i det praktiske kvardagslivet, og på den andre sida ein kamp ho må føre på eit strukturelt og institusjonelt nivå. Sonen krev ekstra oppfølging også utanfor heimen, med spesialundervisning og særlege tilrettelagde omsorgs- og pleieressursar.

Personane Olaug og Daniel finst både innanfor og utanfor det litterære verket: «Eg heiter Olaug. Eg er ei stor dame på førti år.» og «Du heiter Daniel. Du er ein sterk gut på ni år» (s. 9). Vekslinga mellom å vende seg til Daniel vekselvis med namn og vekselvis som «du» går att $\mathrm{i}$ heile romanen. Dette viser korleis Nilssen balanserer portrettet av han og samspelet dei i mellom, med ulike gradar av nærleik og distanse. «Du»-omtalen blir særleg nytta i dei passasjane av romanen der Olaug ikkje heilt forstår $k v a$, korleis eller kvifor Daniel gjer som han gjer, eller når ho tenkjer attende til korleis han var før han byrja endre seg i to-treårsalderen. Ho fortel om han, vel vitande om at han høgst truleg aldri vil kunne kome til å lese det ho har skrive om han, kommentere det eller gi sin versjon av det ho fortel om samspelet dei imellom. For Daniel brukar ikkje språket slik som andre gjer. Han kommuniserer på sin eigen måte og er i verda på sin heilt eigen måte. Daniel er Daniel.

Filosofen Martha A. Fineman (2013) sine tankar om sårbarheit og Rita Felski sitt syn på skjønnlitteraturens særlege plass i samfunnslivet ligg til grunn for korleis eg les Tung tids tale. Fineman utfordrar omgrepet «sårbare grupper». Ho meiner at alle menneske i utgangspunktet må bli sett som sårbare. Dette er eit vesentleg aspekt ved det generelle menneskeverdet. Felski blir nytta for å syne korleis ein kan bruke skjønnlitteratur til å kome nær på hendingar, situasjonar og lagnadar som elles er lite kjende. Skjønnlitteraturen kan vere ei form for laboratorium for etisk refleksjon, seier ho. Gjennom skjønnlitterære framstillingar kan ein vise korleis ulike lagnadar og synspunkt gnissar mot kvarandre. Analysen min legg særleg vekt på korleis Nilssen balanserer portrettet av Daniel, og korleis ho plasserer eg-forteljaren Olaug i ein narrativ spagat som utforskar grensene mellom det å fortelje og det å bli fortalt om. I måten romanen er 
strukturert og fortalt på, ligg både estetiske og etiske vurderingar. Metodisk nyttar eg meg av litteraturvitskaplege nærlesingsstrategiar. Den narrative og estetiske forma har mykje å seie for korleis lesaren blir ført inn i tematikken, og for forståinga av han. Sidan dette er ein roman som så tett byggjer på forfattaren sin eigen livssituasjon, vil eg skrive «Nilssen» når eg meiner forfattaren av romanen, og «Olaug» når eg meiner den tekstinterne forteljaren i verket. Det er naudsynt å undersøkje dei formelle og forteljetekniske sidene av romanen for å forstå kompleksiteten i han. Tung tids tale har ikkje nokon uttalt religiøs tematikk, men reiser grunnleggjande etiske spørsmål om funksjonsvariasjon, menneskesyn og likeverd.

\section{Sårbarheit}

I Tung tids tale møter vi menneske i sårbare situasjonar. Ein av dei dominante tendensane innanfor norsk samtidstidslitteratur har det siste tiåret vore at forfattarar har teke utgangspunkt i eigne liv og familiar i romanane sine. Dette blir gjerne omtala som verkelegheitslitteratur. Karl Ove Knausgård sitt monumentalverk Min kamp 1-6 (2009-11) er å rekne for høgdepunktet, men det førte også til store debattar både innanfor og utanfor det litterære miljøet om i kva grad ein skal setje same krav til personvern og etiske vurderingar innanfor litterære framstillingar av personar og hendingar, som til sakprosa eller avisreportasjar (Egeland, 2015a, 2015b). Eg skal ikkje gå vidare inn i denne debatten. Det særlege utgangspunktet for Nilssens roman er at ho skriv om ein gut som ho veit ikkje har språk til å kunne forsvare seg eller ta til motmæle. «Eg trur det er meir skadeleg å ikkje vise fram verkelegheita slik ho er - både for han, for meg og for andre som har liknande situasjonar i heimane sine», seier Nilssen til Bergens Tidende. «Det meste er dokumentarisk sant. Noko er skrive saman, eg diktar og lyg litt her og der og har bytte om på personar. Men i botnen ligg ei stor kjerne av eiga erfaring» (Sørensen, 2017). Dette er ein viktig uttale, sidan forfattaren her kommenterer sine eigne etiske vurderingar med tanke på det å skrive så tett på eige og andre sitt liv. Å fortelje i romanform byggjer på ei estetisk fortolking av røyndomen. Ein estetisk og litterær representasjon av eit liv og ein lagnad er noko anna enn ein dokumentasjon av det same livet. Fiksjonen forstørrar noko, 
utelet andre ting, stiller skarpt og ser forbi. Gjennom desse medvitne vala blir det skapt eit verk som nettopp skapar gnissingar og friksjon mellom liv og tekst, etikk og estetikk, sidan den estetiske fortolkinga også alltid har ei etisk side. Å fortelje og å bli fortalt om er ikkje det same, og det sårbare ligg i korleis dette blir gjort.

Å peike ut nokre menneske eller grupper av menneske som særlege sårbare grupper, slik som det ofte blir gjort innanfor politiske diskursar, er, for å støtte meg på det filosofen Martha A. Fineman seier, ei problematiserande redusering. Hovudpoenget hennar er at «Vulnerability is ... the characteristic that positions us in relation to each other as human beings, as well as forming the basis for a claim that the state must be more responsive to that vulnerability» (Fineman, 2013, s. 13). For at menneske skal bli oppfatta som like, må alle individ bli behandla på same måten. Dette gjer at same kva dei individuelle forskjellane botnar i, og korleis dei viser seg i kvardagen, det vere seg når det gjeld alt frå alder, klasse, funksjon, seksualitet og så bortetter, så skal alle bli møtte likt og ha lik tilgang til dei same rettane. Utfordringa ligg i dei som ikkje passar heilt inn. Fineman spør om kva det er som skjer med dei som ikkje passar inn dei vande systema og dei kjende kategoriane (2013, s. 16). Å peike på desse gruppene som «særleg sårbare grupper» blir feil, seier ho. Sårbarheit må bli forstått på ein meir kompleks måte. Målet hennar er å føre forståinga av det sårbare tilbake til ein diskusjon kring kva det eigentleg vil seie å vere eit menneske: «The vulnerable subject is the embodiment of the realization that vulnerability is a universal and constant aspect of the human condition. Dependency and vulnerability are not deviate, but natural and inevitable» (Fineman, 2013, s. 17). Sårbarheit er altså noko fundamentalt menneskeleg, og ikkje berre noko som kan bli knytt til særleg utsette grupper. Ein må sjå enkeltmenneska som eit og eit menneske, og ikkje som grupper av særleg utpeika diagnosar.

Nilssen viser oss korleis både Olaug og Daniel er sårbare, og korleis dei er sårbare på ulike måtar. På eit tidleg tidspunkt i livet er alle menneske avhengige av omsorg frå andre. Det er stor sjanse for at vi og seinare vil kome til å trengje det att. Å vere avhengig av andre må derfor bli oppfatta som ein uunngåeleg del av det å vere menneske, seier Fineman. Sjølv om nokre er meir eller mindre avhengige av hjelp og omsorg frå andre, så blir 
det å omtale nokon som sarleg sårbare, mest å forstå som ei utskiljing av dei frå dei hine. Denne språkbuken kan føre til ytterlegare stigmatisering og ei ekstra belastning, seier filosofen. Ein må altså utvide synet på kva det vil seie å vere sårbar. Slik vil Fineman etablere ei universell forståing av det sårbare, der det universelle og det partikulære (individuelle) blir forstått på same nivå. Dette gjer forståinga av sårbarheiter kompleks og opnar opp for ein aksept av korleis det sårbare manifesterer seg i mange ulike former. Desse manifesteringane er på den eine sida knytt til både fysiske forskjellar og mentale, intellektuelle og andre variasjonar av det kroppsleggjorde subjektet. Den andre forma er like viktig. Ho er knytt til den sosiale konstruksjonen av sårbarheita. Denne er knytt til at alle menneske er situert ulikt og inngår i ulike overlappande og samansette økonomiske, sosiale og økonomiske mønster. Det Fineman understrekar, er at variasjonane av «human embodiement» aldri er nøytrale og alltid er individuelle. Det særmerkte med Nilssens roman er at ho set ord på både Olaug og Daniel sine komplekse sårbarheiter - og viser korleis desse er vevd inn i kvarandre. Daniel kan innimellom vere svært krevjande. Ingen veit vel heilt korleis ein skal kommunisere med han. Olaug er frustrert, utsliten og redd. Sjølv om ho til dømes veit korleis ho skal kommunisere med helsebyråkratiet, slit ho med det. Romanen viser korleis dei begge er bundne fast av både personlege og ytre strukturelle, synlege og usynlege politiske trådar. Det dreier seg om kven som kjem til orde, kva som blir fortalt, kven som får fortelje, kven som kan fortelje - og korleis. For at skjønnlitteraturen skal kunne virke på denne måten, må dei som les, kunne leve seg inn i det dei les om.

\section{Krafta i skjønnlitteraturen}

I Uses of Literature seier Rita Felski at det å lese er både ei etisk og politisk handling: « $[\mathrm{t}]$ he act of reading enacts an ethics and a politics of its own right, rather than being a displacement of something more essential that taking place elsewhere» (Felski, 2008, s. 20). Evna til å vise fram ulike menneskelege erfaringar som skapar empati («empathic experiences»), ligg som ei moglegheit i kunsten. Særleg kan dette skje ved å appellere til dei lesarane som på ulike måtar kjenner seg att. For Felski 
er «recognition» - attkjenning - noko som gjer at lesing av skjønnlitteratur kan opne opp for vidare etisk refleksjon: «Ethics means accepting the mysteriousness of the other, its resistance to conceptual schemes; it means learning to relinquish our own desire to know» (Felski, 2008, s. 26). Korleis kan ein litterær tekst opne opp for det mystiske ved ein annan?

Tekstar kan ikkje tenkje, føle eller handle (Felski, 2008, s. 32), men dei kan vise fram menneske som tenkjer, handlar og føler. Dersom dei litterære personane skal ha noko som helst tyding i den omkringliggjande verda, skjer dette ved at dei verkar på dei som les. Forstått på denne måten kan skjønnlitteraturen fungere som eit ideelt laboratorium («ideal laboratory» (s. 32)). Dei estetiske erfaringane skapar ei særleg form for merksemd som krystalliserer eit medvit om at ein er del av ein større fellesskap (Felski, 2008, s. 33). Skjønnlitteratur kan såleis skape merksemd og gi stemme til dei som elles ikkje blir gitt ein talarstol. Ved å vise fram Daniels og familiens liv får Nilssen sin roman ei aktivistisk side.

I Tung tids tale blir det fortalt om ein gut som sjølv ikkje kan samle erfaringane sine i eit samanhengande narrativ eller bruke verbalspråket til å kommunisere med. Gjennom romanen får vi eit sjeldan innblikk i korleis det kanskje er å vere som han. Å framstille noko som kunne hende, framheva Aristoteles som det fremste målet med diktekunsten. Felski byggjer på denne tradisjonen. Ved å vise fram noko og nokon som vi kan kjenne oss att $i$, eller ved å vise fram situasjonar som er meir eller mindre kjende og ukjende for lesarane, fører romanen til merksemd og kunnskapsutveksling. Det er særleg i friksjonen mellom det som er kjend og ukjend, at skjønnlitteraturen har det største potensialet, meiner Felski. Nilssen opnar døra til kvardagslivet til eit barn med særskilde behov, og viser korleis dette påverkar familen sitt liv som heilskap, og heng saman med det generelle samfunnslivet. Slik tilbyr kunsten oss eit nytt perspektiv og gjenkjenninga knytt til det vi veit, men også til grensene for kva det er mogleg å forstå: «the limits of knowing and knowability» (Felski, 2008, s. 49). Dermed blir det mogleg for oss å sjå fleire av nyansane $i$ «the messy and mundane world of human action» (s. 49). Kanskje kan vi oppdage nye nyansar i det vi møter. Lest slik blir det synleggjeringsprosjektet som ligg bak Tung tids tale, ekstra viktig. Ved å gå så tett på både si eiga og sonens sårbarheit, ved å gå inn i det komplekse og rotete og ved å presse 
på grensene for både attkjenning og kunnskapsutveksling blir romanen politisk. Han viser oss kollisjonspunkta mellom det personlege og det institusjonelle, det strukturelle og det private, og korleis dette alltid er eit spørsmål om kven sine forteljingar og erfaringar som kjem til orde - og korleis. For å sjå nyansane i dette må vi gå tett på verket.

\section{Synleggjering}

I løpet av den tida som har gått sidan romanen kom ut, har han sett tydelege spor. Romanen fekk jamt gode kritikkar (sjå t.d. Bentzrud, 2017; Ellefsen, 2017; Hverven, 2017; Granlund, 2017; Nilsen, 2017; Økland, 2017; Hoel, 2017) og har selt i over 40 ooo eksemplar. Nilssen har fått både Brageprisen og Nynorsk litteraturpris for han. At romanen var innstilt til Ungdommens kritikerpris og Bokbloggerprisen og var på listene over årets beste bok 2017 i Bergens Tidende, Dagbladet, Dagens Næringsliv, Klassekampen og VG, seier noko om gjennomslagskrafta tematikken har. Romanen er omarbeidd for teaterscenen (Riksteateret, 2018b). Både romanen og teaterstykket har vekt merksemd innanfor den norske litterære, kulturelle og sosialpolitiske sfæren. Statsminister Solberg (Riksteateret, 2018a) har uttalt at «[j]eg tror boka kan bidra til å gjøre noe med hvordan vi behandler pårørende» (2018b, s. 26).

Tung tids tale er ei lita, lysgrøn, tynn bok med permar av hard papp. Tittelen er trykt direkte på pappen. Sidan boka manglar det mest obligatoriske glansa smussomslaget, verkar boka mest naken og avkledd. Dette er ei bok som også i den fysiske utforminga toler ein støyt. I fleire av fragmenta blir det fortalt om korleis Olaug ryddar unna ting slik at Daniel ikkje skal øydeleggje eller kome til å skade seg på dei. Utforminga av boka, den paratekstuelle sida av ho, kan bli oppfatta som ei form for opning mot Daniel. Sjølv om han ikkje kan lese henne, skal han kunne ta imot boka utan å bli uroa, trass i at sjølv dei minste endringar kan føre til at han blir uroleg. Det nakne og avkledde kan nyttast som en metaforisk inngang til forståinga av den livssituasjonen Nilssen opnar opp for lesarane sine. Ho fører oss lenger og lenger inn i dei samansette dilemma ho, som mor til guten, står i. Korleis ho skal kunne fortelje om sonen, er berre eitt av desse. Når Nilssen går så tett inn i dei relasjonane og hendingane som 
eksisterer utanfor romanteksten, innanfor dei strukturerande rammene som romansjangeren gir, er det ein måte å synleggjere dei på. Romantittelen er ein intertekstuell referanse til eit dikt av Halldis Moren Vesaas. Ved å bruke denne tittelen skriv ho seg også medvite inn i dialog med eit av dei dikta som i norsk samanheng kanskje tydelegast har vorte lese som ein forsvarstale for menneske med særskilde behov. Diktet manar til samhald, til å halde ut og til fellesskapskjensle og solidaritet. Skjebnefellesskapen mellom to som for alltid er knytt saman, er grunntanken i diktet romantittelen støttar seg på. Dei første verselinene lyder slik: «Det heiter ikkje: eg - no lenger. Heretter heiter det: vi» (Vesaas, 1945). Den svenske utgåva av romanen har fått tittelen Till Daniel (2019), noko som i større grad understrekar den relasjonelle og ikkje den estetiske sida av verket.

Olaug kjempar for sonen, og ho kjempar med sonen. Korkje forfattaren utanfor eller forteljaren i teksten legg skjul på at livet med Daniel er ein situasjon som krev alt av henne, både emosjonelt og mentalt. Dette gjeld i rolla som mor for Daniel og to andre søner. I romanen er dei hine familiemedlemmane berre glimtvis med i plottet. Forholdet til Daniel styrer det heile. Dette er eit krevjande forhold på alle måtar, også fysisk, for Daniel kan lugge, klype og slå. «Dette er inga heltehistorie. Det er ei kjærleikshistorie» står det bak på romanen, og i teksten står det:

Lenge visste eg ikkje kva eg skulle gjere når du slo meg og beit meg. Du slo meg. Eg sa nei og flytta handa di roleg tilbake. Du slo meg. Eg sa nei og flytta handa di roleg tilbake. Du slo meg. Eg sa nei og flytta handa di roleg tilbake. Du slo meg. Eg sa nei og flytta hand di roleg tilbake. Du slo meg. Eg sa nei og flytta handa di roleg tilbake. Du slo meg, eg brølte. Du beit meg, eg banka i veggen. (s. 107)

For ein av kritikarane var det episodane av vald som utgjorde romanens mest «sentrale og radikale passasjer» (Økland, 2017). Korleis kan ein finne eit språk for denne opplevinga? Her fører Olaug oss rett inn i det etiske dilemmaet romanen heile tida krinsar rundt. Korleis kan ho gå så tett på eit menneske som ikkje sjølv har noko moglegheit til å fortelje sin versjon av det som hende? Kva var Daniel si oppleving av denne situasjonen? Kva var det som gjorde at han slo og beit? Kva var det han ville kommunisere? Kva er det eigentleg valden uttrykkjer? Det kan aldri Olaug få tilgang til. Ho kan berre fortelje om situasjonen ut frå perspektivet sitt. 
På den måten får også lesaren innblikk i korleis det å fortelje om noko som faktisk lever utanfor romanpermane, alltid er knytt til både etiske og estetiske val. Slik blir Tung tids tale eit eksempel på skjønnlitteraturens viktige synleggjeringsfunksjon, men også her finst det blinde flekkar. Det blir fortalt om Daniel, men han sjølv får inga stemme i romanen. Ei heller har han lenger moglegheit til å bruke språket til å ytre perspektivet sitt utanfor det fiktive universet, slik som Olaug gjer. Olaug fortel. Daniel blir fortalt om. Dette kan bli sett på som eit paradoks, sidan jo nettopp fiksjonen gir ein forfattar moglegheiter til å flytte perspektivet akkurat kvar han eller ho helst vil. Tung tids tale er Olaugs forteljing om livet med Daniel. Kommunikasjonsvanskane hans blir ekstra synlege i forteljinga hennar, sidan han manglar nettopp det språket som Nilssen har.

\section{Form og fragmentert tekst}

Reint formelt liknar Tung tids tale på ei lita dagbok med tydeleg markerte temporale nedskrivingspunkt. Det blir ikkje nytta kapitteloverskrifter, men teksten er delt opp i fem bolkar: «Siste måndag i november» (s. 11-30), «Andre måndag og tysdag i advent» (s. 31-8o), «Siste måndag og tysdag før jul» (s. 81-126), «Første måndag i februar» (s. 127-152) og «Tredje torsdag i mai» (s. 152-156). I alt følgjer vi Olaug og Daniel i eit halvt års tid. Frå notidssituasjonen får vi stadige tilbakeblikk på tida før og etter Daniel vart fødd. Særleg vender forteljaren tankane tilbake til kven og korleis Daniel var før han byrja å endre seg i to-treårsalderen. Tankane hennar kvernar rundt dette. Ho greier aldri å gjere seg ferdig med dette, ei heller forsone seg med at det er noko som truleg er tapt for alltid. På mobilen har ho ein video av Daniel som ho stadig sjeldnare viser til helsepersonellet (sjå t.d. s. 45, 56, 77): «Vi har ein video av at han et yoghurt med skei, heilt roleg og utan søl, seier mannen min. Han tar den ikkje fram. Ingen ber om han heller» (s. 79). I minna til dei som kjende han, finst Daniel slik han var - ein gløgg, nyfiken og kunnskapsrik gut.

Du lærte tidleg å snakke. Du kunne mange ord og sette dei tidleg saman til grammatisk korrekte setningar. Du sa dei til oss. Du stilte spørsmål til oss. Den gongen visste eg ikkje at det var dette som var viktig, men det veit eg i dag. Vi snakka saman. (s. 40) 
«Eg må nesten knipe meg i armen, men dette er ikkje løgn. Det var slik» (s. 43). Men så skjedde det noko. Utviklinga hans stoppa opp, og han greidde aldri å slutte med bleie. Dette faktumet er noko dei mange helsebyråkratane Olaug møter, stadig vender tilbake til i ulike utgreiingsprosessar (s. 78). Det er som om denne eine tingen skuggar over alt det han elles kunne. Lett desperat prøvar foreldra å vise telefonfilmsnuttane for å støtte opp under det som Daniel var til dei uvitande. Dei ser han mest berre som ein utagerande, krevjande, autistisk gut med stadig fleire sosiale og kommunikative utfordringar.

Dagbokstrukturen er med på å forsterke opplevinga av det krevjande i kvardagen. Dei ulike delane er bygd opp av laust samanhengande fragment. Desse varierer frå berre ei line som står åleine på ei side - som «Ein blir meir glad i barna som er annleis» (s. 112), der kursiveringa markerer at dette er ei utsegn frå nokon - til nokre tekstar på to-tre sider som grip tak i konkrete situasjonar, eller der vi får innblikk i Olaug sine indre tankerekkjer. I eit fragment er Olaug og Daniel ute og går tur. Dei møter ein far som byrjar å skryte av den to år gamle dottera si. Dette blir ei ekstra sår påminning for Olaug om kva som har vorte borte for Daniel og henne. «Du var slik som henne, eg var slik som han» (s. 40). Fragment- og dagboksforma gjer dessutan at lesaren får pusterom frå dei heseblesande situasjonane som Olaug står i. Vekslinga mellom dei korte og dei litt lengre tekstane gjer at fleire av sidene berre har nokre få liner og elles står tomme. Denne store, opne «kvitheita» dei uutskrivne boksidene skapar, gjer at den same nakenheita som pregar omslaget til boka, også er eit element i sjølve forteljemåten og den indre komposisjonen av verket. Kontrastane som gjev den faktiske lesaren moglegheiter til å ta pausar i boka, fungerer som ei tydeleggjering av tematikken, og er av dei estetiske grepa som gjer framstillinga av dei personlege lagnadane om til kunst. Eksistensielt alvor og utfordringar ved å skilje seg ut er elles ikkje ein framand tematikk i forfattarskapen hennar (Nilssen, 1998, 2002, 2005a, 2005b, 2012).

\section{Krysspress}

Tung tids tale har to motto som er med på å slå an den kjenslestyrte tonen. Det første er henta frå Lars Amund Vaages essaysamling Sorg og song 
(2016, s. 5): «Eg er autist, det er sant. Det er sant på ein annan måte enn at eg ikkje er det. Me er alle autistar, og ingen er det». Vaage, som sjølv har ei autistisk dotter, skreiv romanen Syngja (2012) tett på sine eigne livserfaringar. Ei liknande samanstilling av seg sjølv om den autistiske sonen nyttar Nilssen seg og av: «Vi to. Autistane» (s. 90). Nilssen har skrive eit kritisk svar til Vaages litterære prosjekt. Der reflekterer ho også over sin eigen forfattarskap og litterære metode: «Autismen har blitt overbygninga for meg. Kva slags forfattarskap kan det då bli? Skal alt eg skriv vere til 'andre i same situasjon'? Har du no forvandla din forfattarskap til eit talerør for oss i 'same situasjon'? Eg veit ikkje» (Nilssen, 2016, s. 20). Den aktivistiske posisjonen er ei rolle ho vegrar seg mot, men som ho likevel går inn i. I kronikken «Raseriet treng også eit språk» (Nilssen, 2017) løftar ho fram andre skjønnlitterære bøker og kjempande mødrer (Rusten, 1979; Ørjasæter, 1976, 2017) og finn trøyst og støtte i ein større litterær lagnadsfellesskap. Men Tung tids tale er noko meir og annleis enn debattinnlegga ho har skrive på bakgrunn av same situasjon. Eg-forteljaren reflekter over Olaug sin kamp som mor, og som skrivande og kjempande kvinne. Ho er sliten mellom det å skulle ta opp kampen og den indre motstanden mot å vere einstydande med saka ho kjempar for. Ho har vore inne på same tematikken i dramaet Stort og stygt (2013), men til skilnad frå romanen nyttar ho til dømes ikkje dei røynlege namna her.

Det andre mottoet i Tung tids tale er henta frå Ingrid Nielsens diktsamling Hemmelig, men aldri som en tyv. Der heier det «[E]ndelig kan jeg slippe forsøket på et abstrakt liv» (2016, s. 6). For Olaug er dilemmaet:

Eg orkar ikkje tale vår sak.

Men så orkar eg det likevel, ikkje berre orkar, eg må, eg lar det velte ut som ei høg hakkende sirene. UTAGERING SJØLVSKADING AVFØRING alltid upassande bresteferdig, alltid uartikulert. TIMEVIS MED LYDAR NATT SOM DAG. Vennene mine rømmer unna, ALT I MUNNEN, GIFT, SIGARETTSNEIPAR, STEIN dei skvett redde inn i lukka ansikt ALLE TING BLIR ØYDELAGDE og kjem ikkje ut. (s. 26)

Bruken av versalane tydeleggjer. Det er som om forteljaren skrik ut mot oss frå romansidene. Den affektive krafta og dei store vekslingane i kjenslene er eit narrativt grep Nilssen nyttar medvite. Eg-forteljaren fører 
oss direkte inn i kjensla av krysspress. Olaug er heilt utsliten. Motvillig må ho erkjenne for seg sjølv at familien ikkje lenger greier å ta hand om Daniel. Dei treng meir hjelp frå det offentlege. Olaug er sterkt bekymra for korleis det skal gå med sonen etter kvart som han blir større. «Han blir jo sterkare, vi merkar at han blir sterkare, atletisk, etter all aktiviteten. Her og no kan eg berre kjenne det, med heile meg, einsemda i å begynne å tenkje tanken, tanken på at eg ikkje kan vere åleine med deg» (s. 91). Situasjonen er prekær.

Eg skreiv søknad om meir hjelp om avlastning på institusjon, samstundes som det sto lesarinnlegg i avisene om at det beste for det funksjonshemma barnet er å få hjelp i heimen, slik at det kan få kjærleik og samhald med foreldre og søsken. ... Eg søkte om femti døgn i halvåret. Femti døgn i halvåret på ein institusjon. Femti døgn i halvåret vil seie 100 døgn i året. 100 døgn er 27,4 \% av årets døgn. På institusjon. (s. 16)

Lesarinnlegga, som ho jo stiller seg generelt sympatisk til, viser fram ein norm som ikkje passar til den livssituasjonen som ho sjølv, Daniel og resten av familien er i. Å erkjenne at ein delvis plass på institusjon er det beste for dei alle, er ikkje noko ho gjer med lett hjarte. Reint retorisk ser vi korleis Nilssen nyttar gjentakingar for å tydeleggjere kor smertepunktet i det ho skriv, er. Når tidsanslaget blir gjentatt tre gongar, får lesaren god tid til å reflektere over kor mange dagar femti dagar eigentleg er. Denne kvantitative tydeleggjeringa skjer også i sjølve teksten, sidan repetisjonane vidare blir multiplisert og utrekna i korrekt prosent. Søknaden og korleis dei ulike offentlege institusjonar svarar på han, er også eit strukturerande element i romanen, sidan fleire av tekstfragmenta handlar om den seindrektige sakshandsaminga.

Liknande repetisjonsmønster finn vi fleire stader i romanen. Eit eksempel er knytt til det Daniel kunne. Formuleringa «Daniel kunne» (s. 54-55) blir nytta heile sju gongar på åtte liner. Repetisjonane synleggjer tapet og sorga over det han lenger ikkje kan. Når Olaug prøver å akseptere det fagpersonane seier, ser ein ei tilsvarande repetering av formuleringane «det er rimeleg» (s. 58-61) og "du føler deg krenkt» (s. 67-68). Olaug viser oss kor utmattande det er å forsøke å kommunisere med Daniel i ein mest omkvedliknande passasje, teke opp att fire gongar: 
«Ta på deg støvelen. (...)» (s. 108). Her viser den tomme parentesen den manglande reaksjonen frå Daniel. Endeleg blir den for Olaug høgst provoserande formuleringa «stå i det» gjentatt heile elleve gongar på to-tre sider (s. 113-115). For korleis kan ein «stå i det» når eit «barn slår og bit? Nei, ho visste ikkje, «dette er veldig tøffe erfaringer» (s. 114). Målt opp mot dette blir den fysiske valden, som også sårar og skader, enklare å forhalde seg til - noko som ein kan finne måtar å «stå i» på. Alle dei velmeinande formuleringane om å «stå i det» er ei munnleg og tom retorisk vending utanforståande lett kan ty til. I romanen ser vi korleis Nilssen, gjennom si konstaterande og repeterande utforsking av formuleringa, avkler utsegna som ein tom frase.

Store delar av romanen handlar nettopp om korleis Olaug strevar som mor, og om korleis ho strevar med språket. Ho søkjer anerkjenning for den krevjande situasjonen. Forteljarstemma er personleg, nær og intens. Ved å bruke den retoriske og emosjonelle krafta som ligg i det å byggje opp ein eg-forteljar så tett på eigne erfaringar, skapar romanen eit sterk emosjonelt trykk mellom tekst og lesar. I eit intervju med Bergens Tidene, med den talande tittelen «Det er grunnleggjande brutalt å la andre ta så mykje av omsorga for barnet ditt» (Sørensen, 2017), seier Nilssen at «[f]ørst og fremst ville eg teikne eit bilde av verkelegheita vi ikkje ser skildra så ofte. Kjenslene våre er underkommunisert. Det ligg eit slags lok over situasjonen vår, som gjer det vanskeleg å faktisk å uttrykkje kor alvorleg utfordringane kan vere». Romanen snakkar om livet bak dei lukka dørene. Slik blir portrettet av ein krevjande livssituasjon ei tydeleggjering av menneskeleg ulikskap og eit sterkt argument for likeverd. Nilssen viser korleis ein kan lykkast i å skrive om eigne autistiske barn og samtidig klare å bevare integriteten deira, for «Tung tids tale er først og fremst en roman fylt med følelser. Sterkest inntrykk gjør lengselen etter kontakt som ligger på og mellom linjene» (Nilsen 2017). Det er denne lengta etter kontakt som viser fram Olaug si sårbarheit, det sårbare ved Daniel sin posisjon og den felles sårbarheita deira i møte med ytre strukturar i samfunnet eller andre menneske si tankeløyse. Den fysiske valden, som også sårar og skader, kan vere enklare å «stå i» enn dei velmeinande eller overberande blikka frå menneske som ikkje eigentleg har innblikk i korleis ein kvardag med Daniel kan arte seg. Frasen «stå i det», som eg 
løfta fram tidlegare, viser kor innhaldslaus og tomt det medkjenslestyrte munnhellet kan arte seg for ein som står $i$ det.

Helsevesenets behov for å setje klare diagnosar blir også utfordra i romanen. Han byrjar med ein prolog utforma som eit hjartesukk over behovet for å måtte setje diagnosar på det som bryt med ein gitt normalitet.

Diagnosesamfunnet, må alt liksom heite noko? Kva skjedde med god, gamaldags maur i beina og makk i ræva, kvifor får ein ikkje berre vere det ein er, utan at det på død og liv må heite noko?

Du spring rundt med impulsane dine, dei kviler aldri i sitt jag etter inntrykk. Eg spring framfor deg og ryddar inntrykka dine bort, eg spring etter deg og ryddar i ruinane kvar gong eg blir for sein.

Det heiter ADHA. Det heiter «annen disintegrativ forstyrrelse i barndommen». Det heiter autisme. Det heiter subklinisk epileptisk aktivitet. Legane seier det er sant, sjølv om eg prøver å nekte.

Du heiter Daniel. Du er ein sterk gut på ni år.

Eg heiter Olaug. Eg er ei stor dame på snart førti. (s. 9)

Motstanden mot det å setje for bastante diagnosar slik at ein ikkje ser variasjonen i enkeltmennesket, er eit av dei tydelegaste plottdrivande elementa i verket. Gjentatte gongar lar forteljaren oss følgje Olaug inn i møte med ulike byråkratar, psykologar eller andre namnlause forvaltarar - eller ho lar oss vente saman med seg i tallause telefonar som går i svarlause loopar. Fagpersonane blir konsekvent omtala gjennom dei funksjonane dei har, eksempelvis «barnepsykologen», «spesialpsykologen» og «fastlegen». Bruken av yrkestitlane er enno ei tydeleggjering av den strukturelle makta som ligg i møtepunkta mellom dei kjempande foreldra og forvaltninga. Med dei språklege og diagnostiske kategoriane fagfolka nyttar i omtalen av Daniel, får dei etter kvart rolla som «sannhetsforvaltere», og som dermed gradvis får «et overtak på hvordan Daniel skal forstås» (Nilsen, 2017). Vi følgjer Olaug frå konstateringa «Din son er autistisk» (s. 66), via «Eg orkar ikkje meir av dette. Hjernen min går i spinn av å tenkje på utgreiiingane» (s. 70) til kapitulasjonen - «Det er det same kva det heiter» (s. 149). Diagnosane sine namn gir tilgang til ressursar på ein meir utførleg måte 
enn personnamnet. Opposisjonen mot kategoriane viser korleis språkbruk styrer, sårar og gjer sårbar. Ved å vere meir enn eit personleg lagnadsdrama reiser romanen ein etisk og politisk debatt rundt velferdsstatens ordningar, organisering og prioriteringar som elles ofte er kjende for enkeltpersonar sine personlege kampar innanfor heimens fire veggar.

\section{Tankeløyse og talande ting}

La oss gå inn midt i dette kvardagsdramaet ein gong til. Olaug strevar med å halde familien saman, med å gje sonen den omsorga og merksemda han krev, og ho strevar, som vi har sett, med å få nok hjelp og avlastning frå det offentlege. Daniel er sterk og aktiv, og av og til kan han altså slå og rope høgt. Det sårbare viser seg også i ordbruken og i Nilssens utkrystalliserande narrative metode. Ho stiller skarpt på ting som på mikroplan får fram korleis Daniels kvardag og livserfaringar skil seg frå andre barns. La oss leggje turen om barnerommet:

No har du berre skåp, seng og sofa på rommet ditt, senga har høge gjerde og gummimadrass, sofaen er den gamle senga di, den du hadde før vi skjønte at du måtte ha spesialseng. Eg nøler når eg skal vise rommet til andre, det er som eit institusjonsrom, eit lagerrom, det må forklarast, og når eg tenkjer på det, tenkjer eg alltid på sakshandsamaren frå Forvaltningen som besøkte oss og stod taus der inne, med stivt blikk og ansikt, meg sjølv som blei meir og meir krakilsk orsakande i forklaringa av at rommet ditt var stygt, ho sa ikkje eit ord. (s. 42)

Like tydeleg som sakshandsamaren manglar ord, blir Nilssens skildring av Olaug sin krakilske tale. «Skjebnen er ikke bare fordelt mellom personene, den hersker i samme grad mellom tingene», sier den tyske filosofen Walter Benjamin (1994, s. 136). Vi får ikkje vite kva det er Olaug seier her. Det er heller ikkje det vesentlegaste. Som lesarar får vi innblikk i den desperasjonen ho som mor føler i denne heilt spesielle situasjonen. Kor tomt rommet er, fråværet av hygge og kos, bamsar og leikar, og alt det rotet som elles pregar eit barnerom, blir ekstra tydeleg for oss gjennom eg-forteljaren si kliniske registrering av dei få tinga som fyller rommet. Fråværet av ting gjer desperasjonen og det prekære i situasjonen ekstra tydeleg for oss. Spenninga mellom registreringa av det som er der, og det 
som etter konvensjonane manglar, skapar det affektive trykket i teksten. Fråværet av barneromsrekvisittane viser kven Daniel er vorten. Dette er krevjande liv. Krevjande litteratur.

I denne scenen er det nettopp dei tinga som manglar, og konvensjonane om kva som gjerne skal finnast på eit barnerom, som i så tydeleg grad signaliserer for oss som lesarar at det er noko spesielt med Daniel, og at livssituasjonen krev ekstra mykje av foreldra og omgjevnadane hans. Gjennom det litterære språket viser Nilssen oss det usynlege - og det er det usynlege som gjer den underliggjande konflikten ekstra tydeleg. «Det er lett å få auge på oss. Vi har ikkje gardiner. Det er lett å sjå meg. Eg har ikkje filter. Det er lett å gjennomskode meg. Eg dreiv ønsketenking» (s. 48). Men mot denne konstateringa finst framleis draumen. Kva er det ho drøymer om?

Å kjøpe blomar og setje dei midt på bordet i stova. Å sjå korleis lyset frå vindauget fell på blomane. Sitje i ro og sjå på dette. Hugse å gøyme blomane bak kjøkkenmaskina før du kjem heim. Ringe gifttelefonen viss eg gløymer det. (s. 87)

Olaug drøymer om ein form for normalitet og ein kvardag utan heile tida å liggje to steg føre i konsekvenstenking. Blomstervasen som skapar kos og hygge i heimen, kan skape uro og fare for sonen. Uroa for Daniel kilar seg alltid inn i alt.

I tillegg til raseriet som veks i Olaug i dei mange Kafka-liknande møtepunkta med helse- og omsorgsbyråkratiet, ligg sorga over å ha mista Daniel slik han var som liten gut. Romanen er driven av ein lengt etter å prøve å forstå sonen slik han er vorten, og korleis verda ser ut frå perspektivet hans. Eg-forteljaren prøvar å akseptere det mystiske ved Daniel, og å skrive fram eit portrett av han som ytar han rettferd slik han er. Gjennom dei episodiske tilbakeblikka får vi kjennskap til Daniel slik han ein gong var. Olaug fortel om korleis guten hennar forsvann, korleis språket hans vart borte, og korleis den han var, gradvis blir plassert inn i diagnostiske kategoriar som foreldra strevar med å akseptere. For dei er han meir enn ein autist, meir enn diagnosen psykisk utviklingshemma. Han er Daniel. Ved å motsetje seg diagnostiseringa viser ho kampen for gutens individualitet og menneskeverd. Romanen balanserer på grensa mellom det kjende og det ukjende, og den rører derfor ved det Felski markerer som grensene for kva ein kan fortelje. (s. 49). 


\section{Konklusjon}

Tung tids tale kan lesast som eit forsvarsskrift for Daniel og andre menneske i liknande situasjonar som han. Romanen løftar fram einskildmennesket og kvardagane bak diagnosane. Olaug viser at trass den sårbare situasjonen han er $\mathrm{i}$, så er Daniel eit individ på lik line med andre. Nilssen viser korleis sårbarheit ikkje berre er knytt til personlege erfaringar og situasjonar, men at det å vere sårbar er ei grunnleggjande menneskeleg erfaring. Den etiske utfordringa ligg i å gi eit så sannferdig og nyansert portrett som mogleg - vel vitande om at Daniel ikkje har språk for å korrigere henne eller fortelje si eiga forteljing om seg sjølv. Slik blir både han og Olaug sårbare, sidan forteljaren si sårbarheit er knytt til i kva grad prosjektet blir vellukka.

Det er ikkje gitt korleis skjønnlitteratur kan gi kunnskap, seier Felski, og understrekar korleis dette heng saman med «how we define the act of knowing» (2008, s. 83). Det er gjennom potensialet for å føre oss inn i ei verd vi ikkje kjenner til - eller har lite kunnskap om - at litteraturen kan utvide, forstørre og omorganisere forståainga vår av korleis ting er (s. 83). Respekten for menneskeverdet og dei mange variantane av det sårbare ligg til grunn for utforminga av og nyansane i utforskinga av det narrative. Tung tids tale er, som denne analysen har vist, ein roman som på mange måtar fungerer som eit laboratorium. Gjennom estetiske verkemiddel kan fiksjonen forstørre og tydeleggjere ei menneskeleg erfaring og syne oss korleis han blir møtt på både individuelt, samfunnsmessig, institusjonelt og politisk nivå. Å skrive ut dette opnar for etiske refleksjonar i og utanfor det litterære verket. Tung tids tale er derfor ein av dei tydelegaste politiske samtidsromanane som er skrivne i Noreg til no.

\section{Referansar}

Aristoteles. (1997). Om diktekunsten. Oversatt fra gresk med innledning og anmerkninger av Sam. Ledsaak, med et essay om å lese Poetikken av Jostein Børtnes. Oslo: Dreyers Bibliotek.

Benjamin, W. (1994). Det tyske sørgespillets opprinnelse. Oversatt av Thor Inge Rørvik. Oslo: Pax Forlag A/S.

Bentzrud, I. (2017, 9. september). Samme hva det kalles. Dagbladet. 
Egeland, M. (2015a). Anerkjennelse og autentisitet i virkelighetslitteraturen. Norsk Litteraturvitenskapelig tidsskrift, 1, 34-48.

Egeland, M. (2015b). Frihet, likhet og brorskap i virkelighetslitteraturen. Edda, nr 3, 227-242.

Ellefsen, B. (2017, 8. september). Det er eksistensielt. Morgenbladet.

Felski, R. (2008). Uses of lterature. Malden/Oxford: Blackwell Publishing.

Fineman, M. A. (2013). Equality, autonomy, and the vulnerable subject in law and politics. I M. A. Fineman \& A. Grear (Red.), Vulnerability: Reflections on a new fundamention for law and politics (s. 13-27). New York: Taylor \& Francis Group.

Granlund, M. R. (2017, 29. september). Å stå det. Dag og tid.

Hoel, O. J. (2017, 16. september). Gripende kjærlighetserklæring til «vanskelig gutt». Ukeadressa.

Hverven, T. E. (2017, 8. september). Å tale. Klassekampen.

Knausgård, K. O. (2009-11). Min kamp 1-6. Oslo: Oktober.

Nielsen, I. (2016). Hemmelig, men aldri som en tyv. Oslo: Gydendal.

Nilsen, G. J. (2017, 8. september). Lengsel etter kontakt. Bergens Tidene.

Nilssen, O. (1998). Innestengd i udyr. Roman. Oslo: Det Norske Samlaget.

Nilssen, O. (2002). Vi har så korte armar. Tilstandsrapportar. Oslo: Det Norske Samlaget.

Nilssen, O. (2005a). Få meg på, for faen. Oslo: Samlaget.

Nilssen, O. (2005b). Hybrideleg sjølvgransking. Oslo: Samlaget.

Nilssen, O. (2012). Kjøkkenbenkrealisme. Erlege historier frå tidsklemma. Oslo: Samlaget.

Nilssen, O. (2013). Stort og stygt (Samlaget): Drama. Oslo.

Nilssen, O. (2016). Sorg og song. Vagant 11.07.

Nilssen, O. (2017). Raseriet treng også eit språk. Morgenbladet, s. 30-31.

Nilssen, O. (2019). Till Daniel. Översettare Joar Tiberg. Stockholm: Albert Bonniers förlag.

Riksteateret. (2018a). Når en roman forandrer. Samtale mellom Erna Solberg og Olaug Nilssen, Litteraturhuset Oslo 21.08.

Riksteateret. (2018b). Tung tids tale av Olaug Nilssen. Programhefte.

Rusten, B. (1979). Gutten i ingenmannsland - en bok om infantil autisme. Oslo: Gyldendal.

Sørensen, B. (2017, 9. september). Det er grunnleggjande brutalt å måtte la andre ta så mykje av omsorga for barnet ditt. Bergens Tidende.

Vaage, L. A. (2012). Syngja. Oslo: Samlaget.

Vaage, L. A. (2016). Sorg og song. Tankar om forteljing. Essay. Oslo: Samlaget.

Vesaas, H. M. (1945). Tung tids tale. Oslo: H. Aschehoug \& Co.

Økland, I. (2017, 10. september). Når mor blir voldsoffer. Aftenposten.

Ørjasæter, T. (1976). Boka om Tore. Oslo: Cappelen.

Ørjasæter, T. (2017). Kjoerligheten har et eget språk - en mors fortelling. Oslo: Kagge Forlag. 


\title{
Infertilitet som sosial og kulturell funksjonshemming: Et perspektiv fra Kamerun
}

\author{
Terese Bue Kessel
}

VID vitenskapelige høgskole

\begin{abstract}
This chapter discusses how infertility is experienced as a social and cultural disability in the context of Cameroon, Africa. Extensive research material from sub-Saharan countries shows that infertile women are facing serious and painful social and psychological challenges. A qualitative research material on the movement Women for Christ in the Evangelical Lutheran Church in Cameroon includes one particular story of infertility experiences. The discussion reveals that the movement's pastoral care practices in the community include infertile women. This movement, in collaboration with the church, provides a space for women who have to cope with infertility to redefine their identity. In this caring community, they develop renewed dignity and status in a context where they are otherwise stigmatized. The church has the potential to further develop this space to also include husbands, so couples can withstand the stigmatization that usually follows the infertile family.
\end{abstract}

Keywords: Evangelical Lutheran Church in Cameroon, infertility, cultural and social disability, care in community, diakonia

\section{Innledning}

I flere afrikanske kontekster er erfaring med infertilitet en betydelig belastning for dem som blir berørt. Tilstanden fører ofte til alvorlige sosiale og psykologiske utfordringer som stigmatisering, verbale og fysiske overgrep (Ofovwe \& Agbontaen-Eghafona, 2009; Anokye, Acheampong,

Sitering av denne artikkelen: Kessel, T. B. (2020). Infertilitet som sosial og kulturell funksjonshemming: Et perspektiv fra Kamerun. I I. M. Lid \& A. R. Solevåg (Red.), Religiøst medborgerskap: Funksjonshemming, likeverd og menneskesyn (Kap. 9, s. 193-211). Oslo: Cappelen Damm Akademisk. https://doi. org/10.23865/noasp.10o.ch 9

Lisens: CC BY-NC-ND 4.0. 
Mpra, Opre \& Barivure, 2017). Infertilitet er et stort helseproblem på det afrikanske kontinentet, ikke minst i land sør for Sahara. Det fører med seg omfattende negative sosiale konsekvenser, særlig for kvinner (Hollos, Larsen, Obono \& Whitehouse, 2009). En kvantitativ studie fra Ghana om psykososiale virkninger av barnløshet for par, avdekker at 40 prosent av respondentene opplevde at livet var satt på vent. 56 prosent trodde at infertilitet hadde ført til sosial ekskludering (Anokye et al., 2017, s. 3.) Kvinner opplever sorg over ikke å kunne oppfylle forventningene omgivelsene har til dem (Dyer, Abrahams, Hoffman \& van der Spuy, 2002; Baloyi, 2009, 2017; Amakwe, 2013). Etnografiske undersøkelser av infertilitet i en rekke land i Sentral-Afrika understreker hvor sentralt barnefødsel og moderskap er for kvinners identitet og sosiale velferd (Lori, 2002, s. 195). Mange kvinner som erfarer infertilitet, opplever å bli tvunget til medisinsk, kulturell og sosial intervensjon for å oppnå graviditet og fullføre morsrollen (Oduyoye, 1999).

Med feministbevegelsen og flere kvinner i akademia de siste 40-50 årene har den menneskelige reproduksjon fått økt oppmerksomhet $\mathrm{i}$ forskning (Inhorn \& van Balen, 2002, s. 3). En større studie, Infertility around the globe: New thinking on childlessness, gender, and reproductive technologies (Inhorn \& van Balen, 2002), undersøker hvordan barnløshet blir forstått og erfart i en rekke land, blant annet i land sør for Sahara, som Kamerun. Reproduktive system undersøkes fra perspektiver som helse og medisin, teknologi og kjønn, politikk og økonomi. Det spørres etter hvordan sosiale og kulturelle praksiser påvirker erfaringen av barnløshet på lokalt nivå. Studien kritiseres for å skildre infertile kvinners elendighet uten å vise til eksempler på aktørskap og myndiggjøring (Richards, 2003, s. 516-517). Selv om det finnes forskning på infertilitet i afrikanske kontekster, er det behov for mer kunnskap om hvordan kvinnene selv finner veier til å skape mening i tilværelsen når det ikke er mulig å forandre tilstanden som barnløs.

Jeg har $i$ et tidligere forskningsarbeid i Kamerun intervjuet kvinner om deres aktive deltakelse i en kirkelig kvinnebevegelse (Kessel, 2014). Da jeg ville vite hva dette engasjementet betydde for dem, fortalte de om erfaringer i kirken, med livet i hjemmet som bakteppe. Et tema som stadig dukket opp, var egne og andre kvinners erfaringer med vold og 
undertrykkelse i familie og nær slekt (Kessel, 2014, s. 61-82). Særlig en fortelling inneholdt erfaringen med infertilitet og opplevelsen av ikke å ha fullført sin plikt overfor ektefellen. Verdens helseorganisasjon definerer infertilitet som fysisk avvik og funksjonshemming. ${ }^{1}$ Når infertilitet i mange afrikanske kontekster påfører en person sosiale stigma som frembringer ekskluderende prosesser, må dette forstås som kulturell og sosial funksjonshemming.

Dette kapitlet undersøker relasjonen mellom infertilitet som del av en erfaring i hjemmet, og omsorgsfellesskap som del av en erfaring i kirken utenfor hjemmet. Helt konkret forsøker jeg å besvare følgende spørsmål: Hvordan skaper kvinner i en afrikansk kontekst en ny fortelling om egne liv med infertilitetserfaring som sosial funksjonshemming? Jeg vil belyse dette ut fra ett case i mitt datamateriale fra Kamerun. Med dette ønsker jeg å bidra til mer kunnskap om hvordan kvinner selv skaper mening i tilværelsen i en svært krevende kulturell og sosial situasjon. Hvilke nettverk knytter informanten seg til, som kan gi nye handlingsrom, slik at det er mulig å fortelle en ny fortelling om seg selv og oppnå fornyet verdighet? Samtidig vil denne studien fra en afrikansk kontekst være et viktig bidrag i en norsk flerkulturell kontekst der tverrkulturell kompetanse blir stadig mer etterspurt, både i offentlig og ideell sektor.

\section{Infertilitet som sosial og kulturell funksjonshemming}

Tradisjonelt har funksjonshemming blitt forstått som en enkeltpersons synlige og kroppslige egenskaper som hindrer livsutfoldelse. Ifølge Internasjonal klassifikasjon av funksjon, funksjonshemming og helse (ICF) ${ }^{2}$ forstås avvik som «slike som man kan legge merke til ved direkte 
observasjon, eller som kan avledes av det man iakttar direkte».3 Denne biologisk-medisinske forståelsen av funksjonshemming, som fysisk avvik, er blitt sterkt utfordret fordi et menneske må ses i lys også av den konteksten vedkommende samhandler med. Det kan like gjerne være samfunnet som er funksjonshemmet. Mangel på fysisk tilrettelegging og sosiale stigma kan føre til sosial funksjonshemming som hindrer en persons deltakelse i samfunnet. Dette perspektivet på funksjonshemming reiser spørsmålet om infertilitet kan forstås som en funksjonshemming som i noen kontekster kan hemme deltakelse i samfunnet.

Det finnes ulike definisjoner på infertilitet - kliniske, demografiske og epidemiologiske. Verdens helseorganisasjon (World Health Organization, WHO) viser til en klinisk definisjon: "a disease of the reproductive system defined by the failure to achieve a clinical pregnancy after 12 months or more of regular unprotected sexual intercourse». ${ }^{4}$ Videre fastslår WHO at infertilitet er den femte største alvorlige globale funksjonshemmingen. Over 34 millioner kvinner er rammet, og de fleste kommer fra utviklingsland.

Tøssebro (2010) drøfter ulike definisjoner på funksjonshemming. Den sosiale modellen vurderer inkludering av mennesket i samfunnet i lys av omgivelsenes evne til å tilpasse seg mennesket uavhengig av funksjonsevne. Dette er en reaksjon mot den medisinske modellen, som analyserer kroppen ut fra et mekanisk perspektiv med tanke på å reparere kroppen slik at den kan tilpasses samfunnets normative normaladferd (Tøssebro, 2010, s. 15-27). Den sosiale modellen identifiserer i stedet samfunnets negative holdninger som systemiske hindre som hemmer inkludering.

Ifølge Khetarpal og Sing (2012) inkluderer alle definisjoner av infertilitet også dysfunksjon og anomali i de reproduktive og endokrine systemene. I artikkelen «Infertility: Why can't we classify this inability as disability?» argumenterer de for at infertilitet er knyttet til sosiale stigma og tabuer og bør forstås i lys av den sosiale modellen (Khetarpal \& Singh, 2012, s. 1). Infertilitet belyst med den sosiale modellen for funksjonshemming kan

3 http://www.who.int/classifications/icf/en/https://ehelse.no/Documents/Helsefaglig\%2okodeverk/ICF_fullversjon-\%2oIS-0354.pdf (hentet 10.10.2018).

4 http://www.who.int/reproductivehealth/topics/infertility/definitions/en/ (hentet 10.10.2018). 
bidra til å identifisere negative holdninger som hemmer deltakelse i samfunnet på ulike individnivåer.

Infertilitet blir også forstått som sosial funksjonshemming på den måten at den infertile trenger bistand til på ulike vis å leve verdige liv, også uten egenfødte barn, som for eksempel gjennom adopsjon (Sandelowski \& de Lacey, 2002, s. 39-40). I dette kapitlet forstås infertilitet i lys av den sosiale modellen (Tøssebro, 2010, s. 17-21), altså som en form for funksjonshemming som blir påført enkeltpersoner på bakgrunn av holdninger og stigma i kulturen, og som like gjerne kunne ha blitt betegnet som kulturell funksjonshemming.

\section{Infertilitet i afrikansk kontekst}

Fra 1978 til 1985 gjennomførte WHO en verdensvid epidemiologisk studie som dokumenterte at infeksjoner ved seksuelt overførbare sykdommer, fødsel eller abort, var hovedårsaken til barnløshet i alle land sør for Sahara (Cates, 1985). I dette området er forekomsten av infertilitet eksepsjonelt høy og berører cirka 20-30 prosent av kvinnene (Larsen, 200o). Parallelt med befolkningsvekst i land sør for Sahara øker også forekomsten av infertilitet. Kamerun inngår i Sentral-Afrikas «infertility belt» med lav frukbarhet (Lori, 2002, s. 194). Med sine mer enn 250 ulike etniske grupper er det store variasjoner i folkegruppenes fruktbarhet. Bamilekefolket utgjør nær 25 prosent av befolkningen og har høyere fruktbarhet enn andre folkegrupper. Mens bamilekefolket har 26 prosent kombinert infertilitet, er tallet 43,9 prosent for resten av Kameruns befolkning, ifølge demografene ved forskningsinstituttet Institut de formation et de recherche démographiques (IFORD) (Feldman-Savelsberg, 2002, s. 216). Usikre data og upålitelige kilder gjør det umulig å fastslå med sikkerhet årsakene til variasjoner i fruktbarhet. Noe av grunnen til økt infertilitet tillegges seksuelt overførbare infeksjoner og lav seksuell debutalder (Richards, 2002, s. 86-87).

En undersøkelse i Vest-Kamerun viser at mens søkelyset på nasjonalt plan har vært rettet mot familieplanlegging, er det på lokalt nivå stor bekymring for ikke å kunne få barn (Richards, 2002, s. 85). Selv om bamilekekvinnene er mer fertile enn kvinner i andre folkegrupper i Kamerun, 
frykter også de barnløshet på grunn av sosiale og psykologiske konsekvenser som hindrer tilgang til landområder og materielle ressurser (Feldman-Savelsberg, 2002, s. 216). De kan møte krav om skilsmisse samt motstand fra familien, som må tilbakebetale brudeavgiften for en infertil kone (Feldman-Savelsberg, 1995). Funksjonshemming er et sammensatt fenomen og inkluderer både kroppslige funksjoner og samfunnets strukturer som hemmer livsutfoldelse. I tillegg kommer samfunnets holdninger. Når en enkeltperson på grunn av barnløshet fratas land, materielle ressurser, trygge rammer og forutsigbarhet i familien, er det ut fra den sosiale modellen for funksjonshemming grunn til å kalle den infertiles tilstand for sosial og kulturell funksjonshemming.

I mange afrikanske kontekster er den førstefødte en viktig begivenhet som bidrar til å stabilisere ekteskapet, fordi barn forener slektene på begge sider (Radcliffe-Brown, 1950, s. 49). Barn gir liv til ekteskap, og barnløse par har ifølge mange kilder små sjanser for å overleve (Baloyi, 2017, s. 1). Mbiti sier det slik: «if there is not yet a child in the marriage there is no guarantee that the marriage will endure» (Mbiti, 1991, s. 41). Barnløshet er tradisjonelt blitt tillagt kvinnen. Det er ikke uvanlig at ektefellen tar kone nummer to uten å innhente medisinske bevis på at det ikke er han som er steril (Baloyi, 2017, s. 1). I mange afrikanske kontekster er infertilitet ikke bare uakseptabelt. Det regnes også som en skam og en unormal tilstand (Baloyi, 2017, s. 2). Utstøtelsesprosessene er komplekse, som dette sitatet viser: «A married African woman who has no child is living on borrowed time. The first threat in most cases is outright divorce, non-negotiable. She is someone because she is married, but she will be nobody outside marriage» (Amakwe, 2013, s. 90).

\section{Kontekst og metode}

I forbindelse med forskningsprosjekt på Kvinner for Kristus gjorde jeg i 2010 og 2011 feltarbeid i byen Ngaoundéré i Kamerun. Kvinnebevegelsen har røtter i norsk misjonshistorie og kamerunsk kirkehistorie (Lode, 1990). Det Norske Misjonsselskap (NMS) startet arbeid i Nord-Kamerun i 1925, og tidlig ble misjonærkvinnene opptatt av de lokale kvinnenes situasjon. De satte i gang leseopplæring og undervisning i hygiene 
og barnestell. Et omfattende kvinnearbeid ble i 1975 systematisert under bevegelsen Femmes pour Christ (Kvinner for Kristus). Noen år tidligere, i 1961, hadde norsk og amerikansk misjon bidratt til å grunnlegge Den evangelisk-lutherske kirken i Kamerun (Lode, 1990). Kvinnebevegelsen skulle få en sentral plass i denne kirken.

Bevegelsens visjon har vært og er å gi kvinner verdighet og utruste dem til å være aktive og bevisste aktører i kirke og samfunn (Kessel, 2014, s. 3-7, 184-189) i en patriarkalsk kontekst som ofte marginaliserer kvinner, og som ikke gir dem samme mulighet til utdanning og økonomisk utvikling som menn (Holtedahl, 1993). I dag er dette blitt en dynamisk bevegelse. De cirka 25000 medlemmene er organisert i mindre grupper og er tilknyttet en lokal menighet i Den evangelisk-lutherske kirken.

Jeg intervjuet 17 aktive medlemmer i Kvinner for Kristus om deres erfaringer i kvinnebevegelsen, med den hensikt å undersøke hvilke prosesser som var i spill med tanke på myndiggjøring og transformasjon i et diakonalt perspektiv. Kirkens biskop ga godkjenning til forskningen innenfor rammen av kirkens aktivitet i Ngaoundéré. Alle lederne i bevegelsen er kvinner. Den øverste lederen samt lokale ledere inviterte meg til å delta på ulike kvinnemøter slik at jeg fikk fortelle om forskningsprosjektet. De lokale lederne bisto med å orientere om at jeg trengte informanter som kunne fortelle om sitt engasjement i Kvinner for Kristus, og om hva det betydde for dem. I mindre samlinger fikk de som meldte sin interesse for å være informanter, mer informasjon om prosjektet. Jeg orienterte dem om prinsipper for anonymitet og om deres rett til å trekke seg fra prosjektet når som helst (Kessel, 2014, s. 30-33). Da dette er en muntlig basert kultur, ble samtykke innhentet muntlig. I konteksten ville skriftlig samtykke ha vært et fremmed element som kunne ha skapt unødvendig avstand mellom informant og forsker og ha styrket en allerede eksisterende ujevn maktbalanse. Det var om å gjøre å være kultursensitiv og ikke bidra til å skape unødvendig avstand. Jeg er født og oppvokst i Kamerun og har bodd mange år i Ngaoundéré. Det var en stor ressurs å kjenne konteksten jeg skulle arbeide i. Intervjuene foregikk hjemme hos informantene, og flere av dem bidro til å skaffe nye informanter, såkalt snøballmetode (Yin, 2011, s. 89). På grunn av de mange etniske gruppene som snakker ulike språk, var et av kriteriene for å bli med i prosjektet at de kunne kommunisere på 
fransk. Jeg har oversatt fra fransk alle sitat som brukes i kapitlet. Av hensyn til anonymitet brukes fiktive navn på informantene.

Alle informantene er på intervjutidspunktet aktive i kvinnebevegelsen i ulike menigheter og bydeler i Ngaoundéré. De er semirurale. Det vil si at de bor i nærheten av en større by med tilgang til helse og utdanning og delvis fungerende infrastruktur som vann, elektrisitet og veinett. Samtidig livnærer de seg i stor grad av jordbruk, som om de bodde på landsbygda. De lever av en improvisasjonsøkonomi og forsørger familien uten faste og forutsigbare inntekter. Mens mange dyrker egne åkrer og selger grønnsaker og frukt på det lokale markedet, identifiserer andre seg som «bayam-sellam», et «Pidgin English»-begrep utledet av «to buy and to sell». Det viser til de som ikke har egen avling men i stedet kjøper jordbruksvarer for så å selge med litt fortjeneste (Kessel, 2014, s. 66-69). Informantene hadde i vestlig forstand kort skolegang, primært grunnskole. Noen hadde gått litt på ungdomsskole og eventuelt videregående skole, før de giftet seg i tenårene. Informantenes fortellinger handlet mye om ansvaret de hadde for mange barn, med tungt kroppslig arbeid for å livnære alle, om oppdragelse, om barnas helse, skolegang og utdanning. Datamaterialet inneholder en fortelling om barnløshet, som er caset jeg drøfter i dette kapitlet. Caset reflekterer hvordan kvinner i en afrikansk kontekst forholder seg til den sosiale og kulturelle funksjonshemmingen som infertilitet innebærer, og hvordan det er mulig å gjenskape ny verdighet og en ny fortelling om seg selv.

\section{Erfaring med infertilitet i Kamerun}

Infertilitet og mor-barn-relasjonen var ikke min sentral i forskning på kvinnebevegelsen. Men for å forstå kvinnebevegelsens betydning for informantene, måtte deres erfaringer i kirken tolkes kontekstuelt i lys av ulike familierelasjoner til barn, ektefelle og storfamilien. Alle informantene hadde ansvar for barn, enten de var enslige eller gift, og enten de hadde gjennomgått svangerskap og fødsel eller ikke. I konteksten eksisterer det ingen hjem uten barn. Denne situasjonen må forstås fra ulike perspektiver. Mange barn trenger et hjem fordi de er foreldreløse, ofte på grunn av hiv/AIDS (Kessel, 2014, s. 124). Fra et voksenperspektiv gir barn 
sosial status og sikrer omsorg i alderdommen (Calves \& Meekers, 1999). For barnløse kan morsrollen bli oppfylt gjennom ansvar for andres barn (Boloyi, 2017, s. 2).

Infertilitet som tematikk lå implisitt i flere av fortellingene i mitt datamateriale, men det er Sasemi som snakker eksplisitt om den personlige erfaringen:

Vi vil leve godt, men barna overgår oss. Når du snakker til dem, ser de på deg som om du ikke var deres foreldre. Jeg vil at vi skal leve i fred i dette huset og overalt der vi er. Vi må leve i fred, men barna hører ikke på oss. Jeg kan si at her jeg er, så har ikke Gud gitt meg noen, men jeg har oppdratt og forsørget mer enn ti barn. ... Nei, de er ikke mine egne barn, Gud har ikke gitt meg noen - de er av min manns familie. Barna kommer til oss. De vokser til. De reiser ut og gifter seg. Mens jeg er her. Mange av disse barna er foreldreløse. Det er mange foreldreløse her. Hos meg. Og jeg har forsørget dem, men barna forstår meg ikke. De ser på meg som om jeg ikke betydde noe for dem. De er alt blitt voksne, ser du? (Sasemi, 5. februar 2010)

Sasemi har hatt ansvar for å livnære og oppdra ti barn, men hun har ikke født noen av dem. I relasjonen til dem opplever hun at de vurderer henne som nærmest ikke-eksisterende. Til tross for mange års forsørgeransvar erfarer hun sosialt stigma og at hun ikke blir verdsatt. De identifiserer henne ikke som forelder og mor, noe som er et tap når det gjelder en kvinnes identitet i en afrikansk kontekst (Oduyoye, 1999). Identitet og selvforståelse er knyttet til fruktbarhet som kroppsliggjør kvinnelighet og styrke (Steady, 2005, s. 326). Det er mulig at Sasemi også har en underliggende frykt for at barna ikke vil komme til å forsørge henne i alderdommen (Calves \& Meekers, 1999).

Sasemi ser ut til å forhandle med sin identitet for å håndtere sorgen over ikke å ha født egne barn. Gjentatte ganger sier hun: «Gud har ikke gitt meg noen.» I et holistisk samfunn er den åndelige og den materielle verdenen sammenvevd. En tydelig gudsforståelse og erfaring av gudsnærvær inngår i verdensbildet og virkelighetsfortolkningen. Sasemi legger ansvaret for barnløsheten over på en høyere, spirituell makt i håp om at byrden hun bærer skal lettes, og at gudsansvaret skal redusere hennes sosiale stigma. 
Infertilitet fremkaller utfordringer i relasjon til den yngre generasjon og ikke minst i forholdet til ektefellen:

De har allerede operert meg én gang, og når jeg drar til sykehuset, sier de at de ikke vet hva de kan gjøre. De vet ikke hva de skal si til meg, og de vet ikke hva som skjer. Endatil at den tingen min [egglederne] er åpen, vet de ikke hvorfor. ... Men jeg ønsker bare at bekymringene skal forsvinne fra hjertet mitt. Fordi - jeg kan legge til noe. For problemet mitt i hjemmet mitt har å gjøre med mannen min. Når du ikke har barn, er det virkelig et stort problem, men det er Gud som gir. Jeg er gift, vi har vært gift i 15 år, men når mannen min går ut og kommer hjem igjen, skjeller han meg ut og sier stygge ting til meg. Det er Gud som gir barn. (Sasemi, 5. februar 2010)

År med gjentatte undersøkelser og behandlinger på sykehus har endt i skuffelser. Selv om egglederne ikke er blokkert, oppnås ikke graviditet, og det skaper furore på hjemmebane. Tilstanden som infertil og mannens irettesettelser medfører både fysiske og psykiske plager:

Du vet, mennene nå for tiden. ... Jeg sier deg at alt her hos oss, kvinner lider på grunn av det. ... Når det gjelder de som bor rundt omkring her, så vet ikke jeg hvilke problem den har med mannen sin, eller den har med mannen sin. Men noen har barn. Gud har gitt dem barn, likevel jager de konene. Selv om kona i huset har barn. Og det er derfor jeg har sagt mange ganger. ... Du gir barn, og likevel skal du lide? Det er ikke bra. (Sasemi, 5. februar 2010)

Den infertile tilstanden legitimerer psykisk vold. Et vanlig uttrykk som brukes i konteksten for å omtale barnefødsel, er «tu donnes des enfants». Direkte oversatt fra fransk betyr det «du gir barn». Sasemi peker på kvinners orienteringspunkt, nemlig å gi barn. Hun reflekterer over hvordan barnefødsler kan forhindre sosial og kulturell funksjonshemming. Samtidig understreker hun at reproduksjon ikke er noen garanti mot vold og undertrykking i familien. Det fungerer ikke nødvendigvis som beskyttelse.

Både nåværende nasjonale leder i Kvinner for Kristus og hennes forgjenger er kamerunere. Maïna Ada Jeanette, leder for Kvinner for Kristus 2009-2018, er ordinert prest, har en doktorgrad og har gitt sitt samtykke til å bli identifisert. I intervju 2010 beskrev hun kvinnenes sosiokulturelle 
kontekst som et underordningsregime der kvinner må akseptere og underordne seg urett uten reell mulighet til å kunne motsi ektefellen: «Tu subit» [fransk ord] betyr at du er forpliktet til å underkaste deg. En form for tvunget underkastelse. ... Du har ikke noe valg». Det patriarkalske miljøet som her beskrives er komplekst. En høyt utdannet kvinne beretter om kontinuerlige utstøtelsesmekanismer som kvinnene hun var leder for, erfarte jevnlig. Lederen bodde i samme område som dem hun omtalte, men utdanning har gitt henne lederposisjon og et annet rom å handle innenfor.

I november 2019 fikk jeg tillatelse av nåværende biskop i Den evangelisk-lutherske kirken til å intervjue noen ledere i kirken for å få mer kunnskap om hvordan kirken generelt og kvinnebevegelsen spesielt forholder seg til infertilitet som tema. Intervjuene og flere uformelle samtaler med venner og lekfolk bekrefter forestillingen om at det er barna som konstituerer ekteskapet og gir det stabilitet og likevekt, som tidligere nevnt. De fortalte om menn som tok seg kone nummer to når den første kona ikke fikk barn, og om svigerfamilier som sto sammen med sine sønner i disse valgene.

Interseksjonalitet er et begrep som viser til kompleksitet og sammenfiltring av flere sosiale kategorier - det «rotete tilblivelsesrom» (Staunæs \& Søndergaard, 2006). Her reises spørsmål om hva kategorier som kjønn, rase, ulike praksiser og kulturell forståelse betyr for en enkeltperson med hensyn til makt og maktrelasjoner (Gullikstad, 2013). De siste 20 årene har begrepet fått stor oppmerksomhet innen kjønnsforskning (McCall, 2005). Gullikstad argumenterer for at det åpner for nye måter å gjøre feministiske analyser på, forhindrer forenkling og understreker kompleksitet. Bildet av «et rotete tilblivelsesrom» kan forstås som en kontekst der det meste er mulig, og der det må gjøres flerdimensjonale analyser. Rommet kan skape undertrykking og på samme tid nye identitets- og handlingsmuligheter. Det kan utvikle seg underkastelsesstrategier, men også motstandsstrategier (Gullikstad, 2013).

Sasemi handler innenfor et «rotete tilblivelsesrom». Patriarkalske verdier bidrar til institusjonalisert mannsdominans og ekskluderende praksiser overfor semirurale kvinner. De har ikke, som menn, samme tilgang til makt, verken i hjemmet eller i viktige samfunnsinstitusjoner (Lerner, 
1986, s. 239). Samtidig baner høy utdanning vei til lederskap og posisjon, som tilfellet er for den tidligere lederen av kvinnebevegelsen hvis stemme etterspørres i internasjonale økumeniske fora. Informantene reflekterer bevisst omkring nødvendigheten av barnas utdanning, fordi de ser på dette som et mulighetsrom de selv ikke har fått. I denne sammenhengen har en av lederne i kvinnebevegelsen vært en inspirator og rollemodell. Mens konteksten rangerer kvinner ulikt med bakgrunn i om de er i stand til å føde barn, gir noen rom i kirken kvinner mer makt og posisjon enn for noen tiår tilbake.

Samtidig er kirken farget av den patriarkalske konteksten den virker i, og den bidrar til både marginaliseringsmekanismer på den ene siden og rom for nye identitets- og handlingsmuligheter på den andre siden. Kvinner er ikke, som menn, bredt inkludert i rådsstrukturen i kirken. De mangler reell innflytelse i kirkens beslutningsorganer. Underkastelsesmønstre og motstandsstrategier lever side om side.

\section{En ny fortelling}

Kirken har åpnet nye mulighetsrom der kvinner kan delta i kirkelige praksiser som tidligere var forbeholdt menn. Ledelsen i Kvinner for Kristus henvendte seg i 1999 til generalsynoden i kirken med spørsmål om å la de lokale kvinnegruppene få lede gudstjenestene i alle kirkens menigheter én gang i året. Dette ble tatt til følge og er siden blitt implementert på morsdagen i mai:

Kvinnene har fått en dato for når de kan arbeide. ... De taler i kirkene. På sykehusene, de taler overalt, til og med på landsbygda.... Kvinnene taler. De gjør alt i kirken. Og jeg er der. Jeg er leder.... Vi må ha liturgien, alt. Det er slik det er. Og dette året, dersom Gud tar vare på meg, er det jeg som skal gjøre dette. Lede kirken. Lede liturgien. Ser du bildet på veggen der? ... De tok bilde av meg. ... Familien er glad. Når du arbeider i kirken, er familien glad. (Sasemi, 5. februar 2010)

Sasemi forteller med stolthet om en arena i kirken som har gitt henne en ny status. Fortellingen om mannen som trakasserer henne hjemme, er byttet ut med familiens stolthet over henne. Hun er ikke lenger bare 
den barnløse. Hun er mer enn det. Hun er liturg og gudstjenesteleder på en religiøs arena som nyter stor respekt i konteksten. I kirken har hun knyttet seg til et rom som gir henne muligheten til ny identitetsdannelse. Bildet i stuen markerer hennes nye status i relasjonen til familien: «Når du arbeider i kirken, er familien glad.» Hennes bevisste valg om å engasjere seg i kvinnebevegelsen har gitt henne tilgang til et rom der kvinner til en viss grad blir inkludert på like vilkår som menn. Sasemi har skapt en ny fortelling om sitt liv.

Fellesskapet i kvinnebevegelsen utrykkes tydeligst gjennom et omfattende diakonalt omsorgsfellesskap i forbindelse med sykdom og død. Når en kvinne uteblir fra gruppesamlinger på grunn av sykdom, blir det organisert sykebesøk med samtale, bønn, sang og en liten gave i form av penger eller mat. Besøkstjenesten gjenspeiler tradisjonelle kollektive praksiser fra landsbygda, basert på verdier som «care in community», omsorg i fellesskap (Kimilike, 2008). Kvinnemøtene brukes også til forbønn for hverandre der også barnløshet og de påfølgende utfordringene blir løftet frem som bønneemne.5 Omsorgspraksiser og sjelesorg skjer i det kollektive rom (Kessel, 2016). Denne formen for sjelesorg inkluderer også kvinner som erfarer sosial funksjonshemming.

Flere afrikanske teologer har tatt et oppgjør med vestlig individuelt basert sjelesorg som er importert til kontinentet ved misjonsvirksomhet og ved at lokale prester har fătt sin utdanning i rammen av vestlig akademisk teologi (Kimilike, 2008, s. 24). Sjelesorg i Afrika må reflektere konteksten den skal utøves i, og den må være sensitiv overfor verdier som gjensidighet og ansvar for hverandre. «Reciprocity», eller gjensidighet, er et sosialt relasjonssystem som baserer seg på en form for utveksling av tjenester blant dem som tilhører en gitt kontekst eller et bestemt lokalsamfunn (Lansley, 1990). En landsby i en afrikansk kontekst kan bare overleve dersom den bygger sin struktur og samhandling på gjensidighet. Derfor kan ikke sjelesorg i Afrika praktiseres som i Vesten. I vestlig kontekst foregår sjelesorgssamtalen primært mellom to personer i et lukket rom. I afrikansk kontekst lider hele landsbyen om noen lider. Det er gjennom landsbyens fellesskap at en person kan heles. Samtidig viser en rekke

5 Leder av kvinnebevegelsen i Ngaoundéré, 11. november 2019. 
studier og mitt case tydelig at det i forbindelse med infertilitet er andre verdier enn gjensidighet som styrer handlingene. Det som var «care in the community» blir til «curse of the community» (Baloyi, 2009, s. 3). Infertilitet endrer støttende felleskap til utstøtende fellesskap.

Fra et sørafrikansk perspektiv spør Baloyi hvordan kirken kan bidra til å gjenreise barnløse kvinners verdighet: «If people are rejected for their infertility status, in which way can pastoral care play a role to help them regain their dignity in African context?» (Baloyi, 2009, s. 1). Vähäkangas undersøker hvordan kristne par lever med barnløshet i to kontekster i Tanzania, og hvordan både enkeltindivider og kollektive fellesskap rammes av lidelse i forbindelse med barnløshet (Vähäkangas, 2009).

En prest i den lutherske kirken i Ngaoundéré påpeker at barnløshet som tema er tabubelagt i konteksten. Han møter det stadig i sjelesorgens rom, men i hans mangeårige tjeneste som prest kan han ikke huske at kirken offisielt har løftet frem behovet for undervisning og holdningsskapende arbeid når det gjelder barnløshet. «Kvinnene er overlatt til seg selv med sin smerte», sier han. ${ }^{6}$ Kvinner fyller kirkene, men kirken ser ikke ut til å ta et oppgjør med en kulturell tradisjon som stigmatiserer infertile kvinner. «Folk gifter seg for å få barn», sier nåværende nasjonal leder i kvinnebevegelsen, «men når det ikke skjer, blir de gjort narr av og kastet ut av svigerfamilien. ${ }^{\urcorner}$Hun møter mange i kvinnebevegelsen som ikke har egenfødte barn. Noen ganger forsøkes dette løst ved adopsjon, men det befrir dem ikke fra stigmaet.

Når forestillingene om den afrikanske landsbyen som et kollektivt og gjensidig fellesskap går i oppløsning i møte med infertilitet, er det behov for mer forskning på både kirkens sjelesorgsspraksis og kirkens rolle i møte med infertilitet som samfunnsproblem. Kirken forvalter et mulighetsrom til å løfte frem verdien omsorg i fellesskap når infertilitet rammer enkeltpersoner og lokalsamfunn. Sosialt stigma knyttet til infertilitet vil ikke kunne endres dersom menn ikke deltar i et radikalt oppgjør med intoleranse overfor barnløse kvinner. Menn trenger et nytt handlingsrom med mulighet til å agere motsatt av hva som forventes av

\footnotetext{
6 Prest i Ngaoundéré, 12. november 2019.

7 Nasjonal leder av kvinnebevegelsen i Ngaoundéré, 11. november 2019. 
dem når ekteskapet ikke medfører graviditet. Kirken har ressursene til å bidra til å gjenreise både kvinners og menns verdighet i ekteskap uten barn.

Svakheten i denne studien er at det bare er ett case som drøftes. Samtidig er fortellingen understøttet av flere studier om infertilitet i land sør for Sahara, samt intervju med ulike personer i den lutherske kirken i Kamerun, som bekrefter det hun sier. I lys av funksjonshemmingsstudier i en nordisk sammenheng med søkelys på sosial inkludering, bekrefter casestudien at sosial funksjonshemming knyttet til infertilitet i afrikanske kontekster bør bli gjenstand for ytterligere forskning. Drøftingen inviterer til videre undersøkelser av hvordan kirken kan bidra til at infertile kvinner kan skape en ny fortelling om sitt liv.

\section{Oppsummering}

Dette kapitlet drøfter hvordan infertilitet erfares som sosial og kulturell funksjonshemming i afrikanske kontekster, med søkelys på ett case fra Nord-Kamerun. Jeg har vist til et bredt forskningsmateriale som bekrefter at barnløse kvinner i Afrika sør for Sahara blir stigmatisert og utstøtt fra sin sosiale sammenheng. Casestudien fra forskning på bevegelsen Kvinner for Kristus peker på at Den evangelisk-lutherske kirken legger til rette for inkluderende prosesser av alle kvinner, uavhengig av deres sosiale anseelse i familierelasjoner. I det multikulturelle Norge stilles det stadig større krav til tverrkulturell kompetanse på alle nivåer. Kunnskap om hvordan infertilitet håndteres i afrikanske kontekster, er av verdi for mennesker som arbeider tverrkulturelt, i offentlig og ideell sektor.

Gjennom kvinnebevegelsen i Kamerun får marginaliserte kvinner del i kjønnsinkluderende handlingsrom i gudstjenesten, der de utvikler ny identitet og opplever ny respekt fra omgivelsene. Samtidig er kirkens rolle overfor infertile kvinner uklar. Kirken adresserer ikke den urett, skam og stigma som påføres dem av ektefelle og svigerfamilie når graviditet uteblir. Slik overlates de til seg selv. I lys av interseksjonalitetsperspektivet fremstår både konteksten og kirken som komplekse og «rotete tilblivelsesrom». Kirken bidrar til oppreisning av kvinner samtidig som den bekrefter status quo ved ikke å stille kritiske spørsmål til kulturelle 
infertilitetsstigmaer og sosial ekskludering. Holdningsskapende arbeid overfor begge kjønn har potensial til å skape nye handlingsmønstre, slik at par sammen kan møte og motstå den stigmatiseringen av familien som infertilitet medfører.

Kvinnebevegelsens omsorgs- og sjelesorgspraksiser i det kollektive rom reflekterer gjensidigheten, som er en identitetsmarkør i den afrikanske landsbyen. Samtidig fører erfaring med infertilitet til at landsbyens støttende felleskap endrer karakter og blir til utstøtende fellesskap. Kvinnebevegelsen bidrar til å gi kvinner som lever med infertilitet som sosial funksjonshemming ny verdighet i det kollektive kirkelige rom, slik at de kan skape en ny fortelling om sitt liv.

\section{Referanser}

Amakwe, B. E. (2013). The problem of infertility in Africa. Human Life Review, 39(2), 89-96.

Anokye, R., Acheampong, E., Mprah, W. K., Ope, J. O. \& Barivure, T. N. (2017). Psychosocial effects of infertility among couples attending St. Michael's Hospital, Jachie-Pramso in the Ashanti Region of Ghana. BMC Research Notes, 10(690), 1-5. https://doi.org/10.1186/s13104-017-3008-8

Baloyi, M. E. (2009). Critical reflections on infertility in black African Christian Communities. Practical Theology in South Africa, 24(2), 1-17.

Baloyi, M. E. (2017). Gendered character of barrenness in African context: An African pastoral study. In die Skriftlig/In Luce Verbi, (Online) 2305-0853, (Print) 1018-6441.

Calves, A. E. \& Meekers, D. (1999). The advantages of having many children for women in formal and informal unions in Cameroon. Journal of Comparative Family Studies, 30(4), 617-639.

Cates, W., Farley, T. M. M, Rowe, P. J. (1985). Worldwide patterns of infertility: Is Africa different? Lancet, 2(8455), 596-98.

Dyer, S. J, Abrahams, N., Hoffman, M, van der Spuy, Z. M. (2002). Men leave me as I cannot have children: Women's experiences with involuntary childlessness. Human Reproduction, 17, 1663-1668. https://doi.org/10.1093/ humrep/17.6.1663

Feldman-Savelsberg, P. (1995). Cooking inside: Kinship and gender in Bangangte idioms of marriage and procreation. American Ethnologist, 22, 483-501.

Feldman-Savelsberg, P. (2002). Is infertility an unrecognized public health and population problem? The view from the Cameroon grassfields. I M. C. Inhorn 
\& F. van Balen (Red.), Infertility around the globe: New thinking on childlessness, gender, and reproductive technologies (s. 216-232). Berkeley, CA: University of California.

Gullikstad, B. (2013). Interseksjonalitet - et fruktbart begrep. Tidsskrift for Kjønnsforskning, 1(37), 68-75.

Hollos, M., Larsen, U., Obono, O. \& Whitehouse, B. (2009). The problem of infertility in high fertility populations: Meanings, consequences and coping mechanisms in two Nigerian communities. Social Science \& Medicine, 68, 2061-2068.

Holtedahl, L. (1993). Education, économie et «ideal de vie»: les femmes de Ngaoundéré. I J. Boutrais \& H. Adala (Red.), Peuples et cultures de l'Adamaoua, (Cameroun) (s. 273-304). Paris: ORSTOM.

Kessel, T. B. (2014). Between God's sharing power and men's controlling power. A quest for diaconal empowerment and transformation in Femmes Pour Christ in Cameroon. Stavanger: Misjonshøgskolens forlag, 2014.

Kessel, T. B. (2016). The Africanisation of diakonia: Care in community with Femmes Pour Christ in Cameroon. I S. Dietrich et al. (Red.), Diakonia in a gender perspective (s. 163-172). Oxford: Regnum Books.

Khetarpal, A. \& Singh, S. (2012). Infertility: Why can't we classify this inability as disability? The Australasian Medical Journal, 5(6), 334-339. http://doi.org/10.4066/ AMJ.2012.1290

Kimilike, P. L. (2008). Integrating the African perspective. I Ø. Eide et al. (Red.), Restoring life in Christ: Dialogues of care in Christian communities: An African perspective. Neuendettelsau: Erlanger Verlag für Mission und Ökumene.

Lansley, J. (1990). Reciprocity. Modern Churchman. 32(3).

Lerner, G. (1986). The creation of patriarchy. Oxford, England: Oxford University Press.

Lori, L. (2002). Problematizing fertility: "Scientific" accounts and Chadian women's narratives. I M. C. Inhorn \& F. van Balen (Red.), Infertility around the globe: New thinking on childlessness, gender, and reproductive technologies (s. 193-214). Berkeley, CA: University of California.

Lode, K. (1990). Appelés à la liberté: Histoire de L’eglise Evangélique Luthérienne du Cameroun. Amstelveen: IMPROCEP éditions.

NOU 2001: 22. (2001). Fra bruker til borger. En strategi for nedbygging av funksjonshemmende barrierer. Hentet fra https://www.regjeringen.no/no/ dokumenter/nou-2001-22/id143931/

Inhorn, M. C. \& van Balen, F. (2002). Interpreting infertility: A view from the social sciences. I M. C. Inhorn \& F. van Balen (Red.), Infertility around the globe: New thinking on childlessness, gender, and reproductive technologies (s. 3-32). Berkeley, CA: University of California.

Mbiti, J. S. (1991). Introduction to African religion. Johannesburg: Heinemann. 
McCall, L. (2005). The complexity of intersectionality. Signs, 30,1771-1802.

Oduyoye, M. A. (1999). A coming home to myself. I M. A. Farley \& S. Jones (Red.), Liberating eschatology: Essays in honor of Letty M. Russell (s. 105-120). Louisville, KY: Westminster John Knox.

Ofovwe, C. E. \& Agbontaen-Eghafona, K. A. (2009). Infertility in Nigeria: A risk factor for gender based violence. Gender \& Behaviour, 7, 2326-23244.

Ogundipe-Leslie, M. (1994). Re-creating ourselves: African women and critical transformations. Trenton, NJ: Africa World Press.

Hess, R. F., Ross, R. \& Gililland, J. L. (2018). Infertility, psychological distress, and coping strategies among women in Mali, West Africa: A mixed-methods study. African Journal of Reproductive Health, 22(1), 60-72. https://doi.org/10.29063/ ajrh2018/v22i1.6

Larsen, U. (2000). Primary and secondary infertility in sub-Saharan Africa. International Journal of Epidemiology, 29(2), 285-291. https:/doi.org/10.1093/ ije/29.2.285

Radcliffe-Brown, A. R. (1950). Introduction. I A. R. Radcliffe-Brown \& C. D. Forde (Red.), African systems of kinship and marriage (s. 1-85).

Richards, S. (2002). Spoiling the womb: Definitions, aetiologies and responses to infertility in North West Province, Cameroon. African Journal of Reproductive Health / La Revue Africaine De La Santé Reproductive, 6(1), 84-94. https://doi. org/10.2307/3583149

Richards, S. C. (2003). Infertility around the globe: New thinking on childlessness, gender, and reproductive technologies. Medical Anthropology Quarterly, 17(4), 515-517. https://doi.org/10.1525/maq.2003.17.4.515

Sandelowski, M. \& de Lacey, S. (2002). The uses of a "disease": Infertility as rhetorical vehicle. I M. C. Inhorn \& F. van Balen. Infertility around the globe: New thinking on childlessness, gender, and reproductive technologies (s. 33-51). Berkeley, CA: University of California Press.

Staunæs, D. \& Søndergaard, D. M. (2006). Intersektionalitet - udsat for teoretisk justering. Kvinder, køn \& forskning, (2-3), 43-56.

Steady, F. C. (2005). An investigative framework for gender research in Africa in the new millenium. I O. Oyěwùmí (Red.), African gender studies: A reader (s. 313-331). New York: Palgrave MacMillan.

Tøssebro, J. (2010). Hva er funksjonshemming. Oslo: Universitetsforlaget.

Yin, R. K. (2011). Qualitative research from start to finish. New York: Guilford Press. Vähäkangas, A. (2009). Christian couples coping with childlessness: Narratives from Machame, Kilimanjaro. Eugene, OR: Pickwick Publications. 


\section{Nettsider}

http://www.who.int/disabilities/world_report/2011/report/en/ (hentet 10.11.2018)

http://www.who.int/reproductivehealth/topics/infertility/definitions/en/ (hentet 10.10 2018)

http://www.who.int/classifications/icf/en/ (hentet 10.10.2018)

https://ehelse.no/Documents/Helsefaglig\%2okodeverk/ICF_fullversjon-\%20IS-0354. pdf (hentet 10.10.2018) 



\title{
Døve, blinde og lamme i Guds rike? Helse og frelse i Det nye testamentet
}

\author{
Anna Rebecca Solevåg \\ VID vitenskapelige høgskole
}

\begin{abstract}
This chapter investigates the relationships between health, healing and salvation in the New Testament. First, I introduce disability studies as a lens for biblical interpretation and show how biblical scholars engage with disability studies theories and concepts. Second, I discuss some New Testament texts to draw out the relations among health, healing and salvation. The healing narratives in the Gospels create an assumption that healing presupposes faith or that salvation somehow should follow from healing. Moreover, a common interpretation of the healing stories is that they signal that all bodies will be healed in the resurrection. I argue that other narratives in the Gospels, as well as Paul's letters, present a somewhat different understanding. Not all non-normative bodies are healed in the Gospels, and the parable of the Great Feast gives people with disabilities a privileged place in the Kingdom of God. Likewise, Paul's own experiences of disability are expressed in a revaluation of weakness as strength.
\end{abstract}

Keywords: biblical interpretation, New Testament, disability history, healing, salvation, disability theology, intersectionality, normate, resurrection

\section{Innledning}

«Din tro har frelst deg, datter», sier Jesus til en kvinne han har helbredet, «du skal være frisk og kvitt plagen din» (Mark 5, 24). Hva er egentlig sammenhengen mellom tro, helse og frelse i Det nye testamentet? Er det slik at Jesu forkynnelse og undergjerninger skaper en forestilling om

Sitering av denne artikkelen: Solevåg, A. R. (2020). Døve, blinde og lamme i Guds rike? Helse og frelse i Det nye testamentet. I I. M. Lid \& A. R. Solevåg (Red.), Religiøst medborgerskap: Funksjonshemming, likeverd og menneskesyn (Kap. 10, s. 213-230). Oslo: Cappelen Damm Akademisk. https://doi.org/10.23865/ noasp.10o.ch10

Lisens: CC BY-NC-ND 4.0. 
Guds rike som et rike befolket av perfekte kropper? Eller finnes det andre måter å forstå de nytestamentlige tekstene på? I dette kapitlet vil jeg først introdusere tverrfaglige funksjonshemmingsstudier som et perspektiv for bibelfortolkning. Så vil jeg drøfte problemstillingen jeg har skissert over. Her vil jeg peke på flere ulike fortolkningstradisjoner og løfte fram bredden i det nytestamentlige materialet når det gjelder forholdet mellom kropp og frelse.

\section{Del 1: Funksjonshemming som perspektiv på Bibelen}

\section{Tre innfallsvinkler}

I innledningen til denne boken skisseres funksjonshemming som et kritisk perspektiv som finnes innenfor en rekke fag og forskningstradisjoner. Dette perspektivet har også fått innpass innenfor bibelvitenskapen. De siste 10-15 årene har det kommet flere antologier (Avalos, Melcher \& Schipper, 2007; Moss \& Schipper, 2011) og monografier som anvender dette perspektivet på enten Det gamle testamentet (Olyan, 2008; Raphael, 2009; Schipper, 2006, 2011) eller Det nye testamentet (Gosbell, 2018; Lawrence, 2013, 2018; Solevåg, 2018). Nylig utkom også den første bibelkommentaren som anlegger et funksjonshemmingsperspektiv, The Bible and Disability: A Commentary (Melcher, Parsons \& Yong, 2017).

Hva vil det si å bruke funksjonshemming som et kritisk perspektiv på en bibeltekst? For min del betyr det at jeg bruker innsikter fra tverrfaglige studier på funksjonshemming og drar veksler på det begrepsapparatet og de teoriene som er utviklet innenfor det feltet. For eksempel tar jeg utgangspunkt i de ulike funksjonshemmingsmodellene som er beskrevet i innledningskapitlet til denne boken. Jeg baserer min forståelse av funksjonshemming særlig på den kulturelle modellen, med vekt på hvordan forestillinger om funksjonshemming kan variere i ulike kulturer og historiske settinger. Jeg er inspirert av Rosemarie Garland-Thomson, som har vist hvordan moderne kultur konstruerer mennesker med funksjonsnedsettelser som annerledes og i motsats til «personen uten funksjonsnedsettelser», eller «the normate» som hun kaller det. Hun mener at dette er en 
falsk dikotomi som tjener til å opprettholde makt og projisere sårbarhet bort fra seg selv (Thomson, 1997, s. 6-8). Jeg bruker også David Mitchell og Sharon Snyder, som har vist at måten funksjonshemming blir brukt på i litteraturen gjennom historien, har noen typiske trekk (Mitchell \& Snyder, 2001). Deres teori er at funksjonshemming brukes som en "protese» for å forklare et hendelsesforløp eller en karakters personlighet. Denne teorien kaller de «narrative prosthesis», og den blir brukt av flere bibelforskere som fortolker Bibelen fra et funksjonshemmingsperspektiv (Lawrence, 2013; Raphael, 2009; Schipper, 2006).

Hvordan går man så fram som bibelforsker når man skal tolke en tekst fra et funksjonshemmingsperspektiv? Det finnes forskjellige måter å gjøre dette på, men jeg vil peke på tre trender som vi kan se blant bibelforskere som er inspirert av tverrfaglige funksjonshemmingsstudier. Innen den første trenden brukes funksjonshemmingsperspektivet som en ny tilgang til å si noe om tekstene i deres historiske kontekst. Ved å rette søkelyset mot funksjonshemming kan en stille nye spørsmål av historisk og litterær art, for eksempel: Hvor finner vi beskrivelser av funksjonshemming eller mennesker med funksjonsnedsettelser i Bibelen? Hvordan framstilles disse i tekstene? Hvilke kategorier og begreper brukes? Er det stigma knyttet til ulike kategorier? På hvilken måte skiller kategoriene og stigmaene seg ut fra kategorier og stigmaer i vår egen samtid? Når vi stiller slike spørsmål til tekstene, oppdager vi nye aspekter ved dem. Rebecca Raphael har for eksempel vist at infertilitet er den viktigste funksjonshemmingen for kvinner i den såkalte fedrehistorien (fortellingene om Abraham, Isak og Jakob), og at disse fortellingene om infertilitet driver narrativet framover (Raphael, 2009, s. 58). Amos Yong har påpekt at Paulus i sine brev fremstiller seg selv som en mann med nedsatt funksjonsevne (Yong, 2011, s. 82-117). Innenfor denne historiske trenden brukes funksjonshemmingsperspektivet med tanke på å få ny historisk kunnskap om synet på funksjonshemming i kulturen der de bibelske tekstene ble til, og den føyer seg dermed inn i feltet «disability history» det vil si funksjonshemmingshistorie.

Innenfor den neste trenden ser vi en kritikk av bibelske funksjonshemmingsmodeller og også en kritikk av tidligere forskning som har vært «funksjonssjåvinistisk» (ableistisk). Denne tilnærmingen retter 
oppmerksomheten mot problematiske aspekter ved Bibelens forstålse av funksjonsnedsettelse og sykdom. For eksempel påpekes det at Gud framstilles som lytefri i Salmenes bok, mens avgudene betegnes som døve og blinde (Koosed, 2017, s. 195). Med andre ord er funksjonsnedsettelse noe negativt som avviker fra gudsbildet og assosieres med feil tro (avguderi). At Gud assosieres med det lytefrie, er også et poeng for James Metzger, som mener at Gud framstilles som en «ableist deity» - en funksjonssjåvinistisk guddom - i lignelsen om det store gjestebudet (Luk 14, 15-24). Han påpeker at $\mathrm{i}$ denne lignelsen inviteres de fattige, blinde og lamme først etter at de opprinnelige gjestene har takket nei (Metzger, 2010, s. 7).

Videre har man innen denne trenden påpekt at Bibelen opererer med problematiske og ekskluderende kategorier knyttet til helse, som har skapt varige stigma. Her trekkes blant annet renhetsforskriftene i Det gamle testamentet fram som tekster som ekskluderer mennesker med diverse «lyter» fra presteskapet (Olyan, 2008, s. 27-31). Når det gjelder Det nye testamentet, er kategoriene «spedalsk» og «demonbesatt» eksempler på stigmatiserende merkelapper knyttet til sykdom og funksjonsnedsettelse (Lawrence, 2013, s. 76-87). Spedalskhet var forbundet med kultisk urenhet, som førte til sosial ekskludering på Jesu tid, mens stigmaet rundt demonbesettelse nok var litt mer diffust. Innenfor den kritiske trenden vil jeg også plassere kritikk av hvordan tidligere fortolkere har manglet refleksjon rundt funksjonshemming. Denne kritikken gjelder både den teologiske tradisjonen gjennom historien og bibelforskere i nyere tid, som gjennom ureflekterte eller fordomsfulle lesninger har fremmet funksjonssjåvinistiske holdninger og problematiske teologiske forståelser av funksjonsnedsettelse. Louise Lawrence har for eksempel påpekt at det er en lang fortolkningstradisjon for å forstå blinde bibelske karakterer som metaforer for mangel på innsikt eller tro (Lawrence, 2013, s. 32-36). Denne tolkningen har kommet til uttrykk i forkynnelsen i kirkene og har spredd en gjengs kristen forståelse av funksjonsnedsettelse som et utslag av svak tro, eller som en prøvelse fra Gud (Eiesland, 1994, s. 70-75).

En annen kritikk som ofte målbæres innen denne trenden, er rettet mot forsøk på å stille moderne medisinske diagnoser på grunnlag av bibelske tekster. Eksempler på dette er forsøk på å bestemme hva slags psykisk lidelse kong Saul hadde (1 Sam 16,14-25), å anta at alle referanser 
til hudsykdommen sa'arat (hebraisk) og lepros (gresk) betegner spedalskhet (lepra), eller å omdefinere demonbesettelse som epilepsi eller kognitive funksjonsnedsettelser (Marx-Wolf \& Upson-Saia, 2015, s. 267; Schipper, 2017, s. 107). Motargumentet er at dette ikke lar seg ikke gjøre, siden vi må forstå beskrivelsene av kropper og symptomer ut fra tekstenes egne sykdoms- og funksjonshemmingskategorier. En slik «retrospektiv diagnostisering», som overfører vår egen tids biomedisinske sykdomsforståelse på fortiden, blir anakronistisk og forkludrer heller enn å gi ny innsikt om tekstene (Graumann, 2013).

Den tredje trenden retter søkelyset mot å omfortolke bibelske tekster for å bruke dem konstruktivt inn mot en funksjonshemmingsteologi. Eksempler på dette er Mikeal Parsons sin fortolkning av Lukasevangeliet, der han argumenterer for at Lukas sin visjon av «Guds rike» var et inkluderende fellesskap av ikke bare syndere og folk fra samfunnets skyggeside, men også mennesker med funksjonsnedsettelser (Parsons, 2006, s. 15). Et annet eksempel er Amos Yong sin lesning av Paulus for en radikal inkludering av mennesker med kognitive funksjonsnedsettelser som «de mest sentrale og ærefulle lemmene på Kristi kropp» (Yong, 2011, s. 105).

I denne beskrivelsen har jeg tatt løselig utgangspunkt i en inndeling som bibelforskeren Hector Avalos har gjort, der han beskriver trendene som «historicist,» «rejectionist» og «redemptionist» (Avalos, 2007). Avalos mener at disse tre trendene er vidt forskjellige i både hensikt og metode, og han er selv svært kritisk til en «redemptionist»-tilnærming, altså det jeg kaller «konstruktiv omfortolkning». Jeg mener at alle trendene har noe for seg, og at de også overlapper mer enn Avalos vil ha det til. Selv forsøker jeg å kombinere en historisk-kritisk tilnærming med både kritiske og konstruktive perspektiver (Solevåg, 2018, s. 158-160), og det samme gjør blant andre Lawrence (2013). Selv om disse innfallsvinklene kombineres, må utgangspunktet være en forståelse av den historiske konteksten. Det vil jeg gå nærmere inn på i de to neste avsnittene.

\section{Historiske studier av funksjonshemming}

Funksjonshemmingshistorie er et voksende felt innenfor historieforskningen. En viktig innsikt fra dette feltet er at begrepene og kategoriene 
som de historiske tekstene opererer med, ofte er svært forskjellige fra våre egne. Man skal også være klar over at den forståelsen av kropp, helse og sykdom som ligger bak de ulike begrepene, er svært forskjellig fra moderne medisin. Historikere som er interessert i funksjonshemming, har diskutert om det i det hele tatt går an å snakke om funksjonshemming som et historisk fenomen. Dersom en historisk epoke opererer med helt andre begreper og kategorier enn oss, og ikke har et eget ord for «funksjonshemming», blir det ikke da anakronistisk å stille slike spørsmål med utgangspunkt i moderne forestillinger? Jeg mener at det er mulig. Historiske spørsmål stilles alltid med utgangspunkt i moderne forestillinger, og andre kategorier, som kjønn og religion, er blitt utforsket i antikken, selv om gresk og latin ikke har ord som tilsvarer disse moderne begrepene nøyaktig. Derfor mener jeg at vi kan bruke begreper som «funksjonshemmet» eller «person med nedsatt funksjonsevne» på en åpen og tentativ måte om mennesker som kan ha opplevd begrensninger i sine muligheter til å utføre dagligdagse aktiviteter på grunn av skade, sykdom, medfødte lidelser eller aldring, og også om folk med et utseende som gjorde at de ble assosiert med samtidens forestillinger om ikke-normative kropper (Turner, 2012, s. 11). ${ }^{1}$

Siden Bibelen er en samling tekster som er 2000-3000 år gamle, må utgangspunktet for å utforske funksjonshemming i Bibelen være å se tekstene i deres historiske kontekst. Kontekstene varierer, siden tekstene er blitt til på ulike tider og forskjellige steder og også i forskjellige språklige sammenhenger. Mens Det gamle testamentet er skrevet på hebraisk og er blitt til over en periode på omtrent sju hundre år (ca. 1000-30o fvt.) innenfor kulturer i det nære Østen, har Det nye testamentet en snevrere tids- og kulturhorisont. Her er alle tekstene blitt til i det første eller tidlig i det andre århundret innenfor rammen av det gresktalende, østlige Romerriket. Siden Det nye testamentet er det sentrale i dette kapitlet, skal jeg si litt mer om denne historiske konteksten knyttet til funksjonshemming.

1 Originalsitat: «[...] potentially may have faced restrictions on their ability to carry out everyday activities through injury, disease, congenital malformation, aging or chronic illness, or whose appearance made them liable to be characterized by contemporary ideas associated with non-standard bodies.» 
Litt forenklet kan vi si at det fantes to ulike paradigmer for hvordan folk i middelhavsområdet på Jesu tid forsto sykdom og funksjonshemming. På den ene siden fantes det en folkelig oppfatning. Den hadde sitt utgangspunkt i forestillingen om at kroppen kunne invaderes av ånder, som dermed forårsaket mange slags sykdommer. Daimonia er det greske ordet for laverestående gudevesener. Innenfor de polyteistiske religionene i middelhavsområdet hadde en forestillinger om demonbesettelse, men ikke som noe entydig negativt. Tenkt for eksempel på oraklet i Delfi, som kunne spå. Dette er et eksempel på en positiv «demonbesettelse» der den besatte fikk en gudelik evne, nemlig evnen til å se inn i framtiden. Men i jødiske og kristne kilder, altså de monoteistiske religionene, er demonbesettelse noe entydig negativt som forårsaker sykdom og smerte. Her knyttes demonbesettelse til det onde (Satan), som står i opposisjon til det gode (Gud).

Det andre paradigmet, som var en mer lærd tilnærming, baserte seg på den greske medisinske forståelsen av at god helse betydde en kropp i balanse. Den hippokratiske legekunsten, oppkalt etter den legendariske legen Hippokrates, vokste fram i Hellas i århundrene før vår tidsregning. Dette var både en vitenskap og en praksis. Leger som til daglig behandlet syke, skrev samtidig bøker der de prøvde å forklare og systematisere det de observerte. Den hippokratiske grunnideen var at kroppen er frisk dersom det er likevekt mellom de fire kroppsvæskene (blod, flegma, sort galle og gul galle), som i sin tur er avhengig av likevekt mellom varmt og kaldt, tørt og fuktig (Nutton, 2004, s. 72-86). Hvordan man skulle behandle den syke, hang tett sammen med årsaksforståelsen. Dersom «diagnosen» ble oppfattet som demonbesettelse, var kuren eksorsisme; den onde ånden måtte kastes ut med makt og autoritet. Dersom man tilhørte det hippokratiske paradigmet, var målet å gi behandling og pleie som gjenopprettet balansen i kroppen. Slik behandling dreide seg mye om diett, lett trening og regulering av søvn, men også i noen tilfeller om inntak av medisiner, årelating, kopping eller kirurgiske inngrep. Disse to paradigmene levde side om side og ville i dagliglivet krysse hverandre og flyte over i hverandre, men vi kan merke oss at Jesus sine helbredelser liknet mest på den folkelige tenkningen om sykdom og funksjonshemming som invasjon av demoner. 
Det finnes ikke ord for funksjonshemming på gresk eller latin, de to hovedspråkene i Romerriket. I Det nye testamente, som er skrevet på gresk, dukker av og til variasjoner av sammenstillingen «døve, blinde og lamme» opp. For eksempel står det i Luk 14, 13: «Nei, når du skal holde selskap, så innby fattige og uføre, lamme og blinde». Matteus forteller om dem Jesus helbredet på denne måten: «Store folkemengder kom til ham, og de hadde med seg lamme, uføre, blinde, stumme og mange andre» (Matt 15, 30). Blant de spesifikke helbredelsene evangeliene forteller om, er det mange døve, blinde og lamme. Bibelforskeren Rebecca Raphael har kalt denne sammenstillingen, som også finnes i Det gamle testamentet, for «den bibelske funksjonshemmingstrilogien». Hun mener at sammenstillingen viser at man hadde en forestilling om funksjonshemming som en overordnet kategori, selv om hebraisk ikke hadde et eget ord for det (Raphael, 2009, s. 13-15). «Døve, blinde og lamme» fungerer på tilsvarende måte i evangeliene, som en samlebetegnelse for ulike funksjonsnedsettelser.

Det finnes også to andre greske ord - noson og astheneia - som betegner sykdom generelt. Noson, som kan bety sykdom eller lidelse, brukes av og til som en samlebetegnelse for alle Jesus helbredet, og inkluderer dermed funksjonsnedsettelse: «Han helbredet mange som led av forskjellige sykdommer [nosois]» (Mark 1, 34). Substantivet astheneia betegner svakhet, men brukes ofte om sykdom og funksjonsnedsettelse i antikke greske tekster. I fortellingen om den syke ved Betesda brukes ordet som en samlebetegnelse for den gruppen av mennesker med ulike funksjonsnedsettelser som var samlet der: «Der lå det mange syke [asthenountōn], blinde, lamme og uføre» (Joh 5, 3).

\section{Interseksjonalitet - funksjonshemming handler om mer enn helse}

Den medisinske modellen som preger vår kultur og kontekst, har skapt en forestilling om at funksjonshemming er en helserelatert kategori (se innledningskapitlet). Etter min mening er denne forestillingen for snever dersom vi skal få en forståelse av hvordan det var å leve med en funksjonsnedsettelse i førmoderne tid. Erfaringer av funksjonshemming 
henger sammen med og påvirkes av en persons kjønn, klasse, alder, etnisitet, religion og så videre. Her drar jeg veksler på innsikter fra teorier om interseksjonalitet (de los Reyes \& Mulinari, 2005; Kartzow, 2012). Enkelt sagt handler interseksjonalitet om å være bevisst på at ulike identitetskategorier overlapper og krysser hverandre, og på at maktstrukturer dermed ofte er svært komplekse. For eksempel ville det å være lam på Jesus sin tid bety noe helt annet for en rik mann, som kunne få slavene sine til å bære seg, enn det ville bety for en slave, som dermed mistet sin verdi som arbeidskraft. Slaver med funksjonsnedsettelse som eierne ville kvitte seg med, ble ofte satt igjen i templene til legeguden Asklepis (Gosbell, 2018, s. 289).

En annen faktor er kjønn. Det gresk-romerske mannsidealet var veldig rettet mot styrke og mot, og den ideelle mannen skulle ha en sterk, frisk og veltrent kropp. Som nevnt betegner det greske ordet astheneia både sykdom og svakhet. Siden svakhet ble forbundet med den kvinnelige natur, ble sykdom og funksjonshemming forbundet med det feminine heller enn det maskuline. Religion er enda en faktor. En kronisk sykdom som hadde religiøse konnotasjoner i en jødisk kontekst, for eksempel blødninger eller hudsykdommer, og som her ville føre til stigma og sosial eksklusjon, kunne være helt uproblematisk i en annen religiøs kontekst, som for eksempel den romerske.

\section{Del 2: Henger helse og frelse sammen i Det nye testamentet? Helbredelsesfortellingene}

Når jeg i denne delen skal se på hva slags sammenkoplinger som finnes mellom helse og frelse i Det nye testamentet, er det naturlig å begynne med helbredelsesfortellingene fordi disse er så velkjent. Helbredelse fra sykdom og funksjonsnedsettelse er en viktig del av Jesu virke i alle evangeliene. Slik oppsummerer Matteus hva Jesus gjorde: «Siden dro Jesus omkring i hele Galilea; han underviste i synagogene deres, forkynte evangeliet om riket og helbredet all sykdom og plage hos folket» (Matt 4, 23). I de synoptiske evangeliene (Matteus, Markus og Lukas) 
signaliserer helbredelsene at Guds rike er nær. Disse evangelistene forteller til sammen nærmere femti helbredelsesfortellinger. Hos Johannes er det færre helbredelsesfortellinger, men de har større symbolsk tyngde. De tre han gjengir (embetsmannens sønn [Joh 4, 46-54], den syke ved Betesda [Joh 5, 1-15] og mannen som var født blind [Joh 9, 1-41]), er blant de sju «tegnene» som peker på Jesu guddommelige opphav i Johannesevangeliet (Anderson, 2011, s. 31-32).

I noen helbredelsesfortellinger er det overlapp mellom helbredelse og oppstandelse, for eksempel i fortellingene om Jairus' datter (Mark 5 , 21-43), embedsmannens sønn (Joh 4, 46-54) og Lasarus (Joh 11, 17-44). Allerede i de første århundrene av kristendommens historie ble det vanlig å tolke Jesu helbredelses- og oppstandelsesundere som en forsmak på Jesu makt til å oppreise troende til evig liv etter døden (Moss, 2011).

I flere av helbredelsesfortellingene ser det ut til å være en slags sammenheng mellom helbredelse og frelse. «Din tro har frelst deg», sier Jesus som nevnt til kvinnen med blødninger (Luk 8, 48), og «det skal bli som dere tror» til de to blinde mennene som har bekjent sin tro på Jesus sine helbredende evner (Matt 9, 29). Tro og frelse tematiseres også i flere andre helbredelsesfortellinger. Offiseren i Kapernaum (Luk 7, 6-19) og faren til en gutt med en ånd som gjør ham stum (Mark 9, 24) bekjenner begge sin tro. Faktisk er det oftest familienes og hjelperes tro som framheves i disse fortellingene, mens svært få retter oppmerksomheten mot den helbredede sin egen tro. Men ofte blir faktisk ikke tro tematisert i det hele tatt (se f.eks. Matt 8, 14-15; Mark 5, 1-17; Luk 14, 1-5)

Også synd er en tematikk som kommer opp i helbredelsesfortellingene. Men også her er det vanskelig å se en entydig sammenheng mellom synd og sykdom eller funksjonshemming. I fortellingen om den lamme mannen med fire hjelpere tilgir Jesus den lamme mannen for hans synder (Mark 2, 5). Den syke ved Betesda sendes av gårde med en advarsel: «Nå er du blitt frisk. Synd ikke mer, for at ikke noe verre skal hende deg» (Joh 5 , 14). Begge disse fortellingene antyder at funksjonshemmingen kan være forårsaket av synd. Et annet sted i Johannesevangeliet, i fortellingen om mannen som var født blind, avviser likevel Jesus at funksjonshemming er straff for synd: 
Da Jesus kom gående, så han en mann som var født blind. Disiplene spurte da: «Rabbi, hvem er det som har syndet, han selv eller hans foreldre, siden han ble født blind?» Jesus svarte: «Verken han eller hans foreldre har syndet. Men nå kan Guds gjerninger bli åpenbart på ham.» (Joh 9, 1-3)

I denne teksten løfter Jesus fram åpenbaringsaspektet ved helbredelsene. Gjennom å helbrede mannen kan Jesus vise at han er sendt fra Gud. Fra et funksjonshemmingsperspektiv kan det virke vel så problematisk at en person har vært blind hele livet bare for at Jesus skulle få sjansen til å helbrede ham og dermed vise at han er Guds sønn, som at funksjonsnedsettelse skulle være forårsaket av synd (Carter, 2011; Hull, 2001, s. 49). Funksjonshemmingsteologen Nancy Eiesland avviser begge deler, men understreker at dette har vært vanlige tolkninger av helbredelsesfortellingene (Eiesland, 1994, s. 70-75). På grunn av denne fortolkningstradisjonen snakker funksjonshemmingsteologen Sharon Betcher om «the terror of the miracle tradition». Disse tekstene er blitt brukt til å objektivere mennesker som lever med funksjonsnedsettelse, og de er derfor «terrortekster» for dem (Betcher, 2013, s. 165). Hun mener ikke at tekstene dermed må forkastes, men at de kan leses i et annet lys. Funksjonsnedsettelse som en annerledeshet som krever utvisking, er en moderne lesning av tekstene, mener hun. Disse fortellingene ble til i en tid da det å være døv, blind eller lam ble forbundet med fattigdom, slaveri og andre stigmatiserte grupper i samfunnet. I en slik kontekst er fortellingene om døve som hører og lamme som går en protest mot krefter som undertrykker, og en bekreftelse på at Gud er på de utsatte sin side. Dersom fortellingene tolkes slik, kan de like gjerne fortelles av en som halter, eller av en som ikke lenger ser, uten at budskapet undergraves (Betcher, 2013, s. 173).

\section{Andre aspekter i evangeliene}

Jeg vil nå peke på noen andre tekster fra evangeliene og Apostlenes gjerninger som kan være interessante for temaer knyttet til funksjonshemming, tro og frelse. I Jesus sine lignelser og taler brukes noen ganger sykdom og funksjonshemming som bilder eller eksempler. For eksempel finnes det utsagn der Jesus omtaler seg selv som lege. Som svar på kritikk fra de skriftlærde om at Jesus er gjest hos tollere og syndere, svarer han: 
«Det er ikke de friske som trenger lege, men de syke.... Jeg er ikke kommet for å kalle rettferdige, men syndere» (Mark 2, 17 // Matt 9, 12-13). I dette utsagnet etableres en metaforisk sammenheng mellom det å være syk og det å være synder. På samme måte som syke trenger lege, trenger syndere frelsen gjennom Jesus. Selv om ikke utsagnet forbinder sykdom direkte med synd, har koblingen fått vidtrekkende konsekvenser gjennom måten den er blitt brukt på i kirkehistorien, som en kjernemetafor for frelse og omvendelse (Eiesland, 1994, s. 71-72). Utsagnet er ofte blitt koplet sammen med en tolkning av helbredelsesfortellingene som forsmak eller tegn på Jesu makt til å frelse de troende i oppstandelsen.

På samme måte som legekunst og helbredelse er blitt tolket som positive metaforer for omvendelse og frelse, dukker funksjonsnedsettelse og sykdom opp som negativt ladde bilder, som i dette Jesus-ordet:

Øyet er kroppens lampe. Om øyet ditt er klart, er det fordi kroppen er fylt av lys. Men om øyet ditt er sykt, er det fordi kroppen er fylt av mørke. Er nå lyset i deg mørke, hvor dypt blir ikke da mørket! (Matt 6, 22-23)

I et annet Jesus-ord finner vi en litt annen kobling mellom synd og kroppslig tilstand:

Om hånden din lokker deg til fall, så hugg den av! Det er bedre for deg å gå lemlestet inn til livet enn å ha begge hender og komme til helvete, til ilden som aldri slukner, der marken som eter dem, ikke dør og ilden ikke slukner. Og om foten din lokker deg til fall, så hugg den av! Det er bedre for deg å gå halt inn til livet enn å ha begge føtter og bli kastet i helvete, der marken som eter dem, ikke dør og ilden ikke slukner. Og om øyet ditt lokker deg til fall, så riv det ut! Det er bedre for deg å gå enøyd inn i Guds rike enn å ha begge øyne og bli kastet i helvete, der marken som eter dem, ikke dør og ilden ikke slukner. (Mark 9, 43-48)

I dette utsagnet holdes kroppslig integritet og perfeksjon opp som en mindre verdi enn det evige livet i Guds rike. Candida Moss, en bibelforsker som bruker funksjonshemming som perspektiv, argumenterer for at denne teksten står i kontrast til helbredelsesfortellingene og den underliggende analogien mellom helse i dette livet og frelse i det neste, som kan leses ut av dem (Moss, 2017, s. 291-294). I dette utsagnet vendes funksjonshemming fra noe negativt til noe positivt. I stedet for å representere konsekvensen av 
synd er funksjonshemming her beskyttelse mot synd. Å kunne se framstilles derimot som en mulig årsak til synd (Moss, 2017, s. 294).

Også i lignelsen om det store gjestebudet i Lukasevangeliet gis funksjonshemmede en framtredende plass i Guds rike. I lignelsen fortelles det om en mann som skulle holde gjestebud og innbød vennene sine, men alle avslo. Mannen beordret da tjeneren sin: «Gå straks ut på byens gater og torg og hent inn de fattige og uføre og blinde og lamme» (Luk 14, 21). Det har vært vanlig å forstå referansen til «fattige og uføre og blinde og lamme» $\mathrm{i}$ denne lignelsen allegorisk, som en henvisning til inkluderingen av ikke-jøder i det troende fellesskapet. Ut fra et funksjonshemmingsperspektiv argumenterer Louise Gosbell for at lignelsen heller skal forstås som en radikal inkludering av mennesker med funksjonsnedsettelser (Gosbell, 2018, s. 227-228). Hun henviser til Jesu råd til tilhørerne like før han forteller lignelsen, der han oppfordrer dem til å innby fattige, uføre, blinde og lamme når de holder selskap (Luk 14, 14). Gosbell mener at Lukas her tydeliggjør forskjellen mellom vanlig gresk-romersk festpraksis, der bare de mest prominente borgerne ble invitert, og Jesus-bevegelsens inkluderende praksis, der man innbød samfunnets utstøtte. Denne praksisen skulle speile inkluderingen av mennesker med funksjonsnedsettelser i det framtidige gudsriket (Gosbell, 2018, s. 228).

Vi skal heller ikke glemme at ikke alle med annerledes kropper helbredes. Fortellingene om kortvokste Sakkeus (Luk 19, 1-10) og den etiopiske evnukken (Apg 8, 24-40) er eksempler på fortellinger om personer med kroppslige stigmaer som blir inkludert i trosfellesskapet slik som de er (Solevåg, 2013, 2020). Et annet eksempel på «ikke-helbredelse» er måten Jesu kropp beskrives på etter at han er stått opp fra de døde. Både Johannes og Lukas omtaler Jesus sine sårmerker etter korsfestelsen (Luk 24, 39-40; Joh 20, 27). Den kroppen Jesus har etter oppstandelsen, framstår som annerledes. Maria får ikke berøre ham (Joh 20, 17), og han kan bevege seg gjennom lukkede dører og forsvinne foran øynene på disiplene (Luk 24, 31). Men kroppen hans er likevel merket, og dette blir et tegn på identitet og kontinuitet. Sharon Betcher mener at Jesu sårmerkede oppstandelseskropp er en viktig bibelsk motstemme mot den driven mot utvisking av annerledeshet som finnes i helbredelsesfortellingene. På samme måte som evangeliene husker Jesu sår som en integrert del av 
hans identitet, er de forskjellene som merkes som «funksjonsnedsettelse», en integrert del av identiteten til dem som lever med dem, mener Betcher (Betcher, 2013, s. 180-181).

\section{Paulus lest i et funksjonshemmingsperspektiv}

Dersom vi skal danne oss et bilde av hva Det nye testamente har å si om relasjonen mellom helse og frelse, må vi også se på brevene til Paulus. Selv om Apostlenes gjerninger forteller at Paulus ble helbredet fra midlertidig blindhet i forbindelse med sin omvendelse (Apg 9, 1-19), nevner Paulus aldri denne episoden i brevene sine. Mange regner dermed dette som en legendarisk heller enn en historisk episode. Men i brevene forteller Paulus flere ganger om egne erfaringer med dårlig helse og kroppslig svakhet. I brevet til galaterne sier han at han kom til Galatia første gang "på grunn av en sykdom [astheneia]» (Gal 4, 13), og han minnes at galaterne ikke møtte ham med forakt, men at de «ville ha revet ut øynene deres og gitt dem til meg, om det var mulig» (Gal 4, 15). I første korinterbrev gir han en liknende beskrivelse av seg selv, der han fremhever sin svakhet: «Svak [astheneia], redd og skjelvende opptrådte jeg hos dere. Jeg forkynte ikke mitt budskap med overtalende visdomsord» (1 Kor 2, 3-4). I andre korinterbrev forteller han at han er blitt utsatt for piskeslag, har sittet i fengsel og har lidd for evangeliets skyld (2 Kor 11, 23-26), og han beretter om en «torn i kroppen» som Gud har gitt ham. Denne lidelsen tryglet han Gud om å ta bort, men fikk som svar at «[m]in nåde er nok for deg, for kraften fullendes i svakhet» (2 Kor 12, 8).

Det finnes altså mange hint i Paulus sine brev om at han hadde personlige erfaringer med sykdom, smerte og svakhet og en kropp som ikke svarte til den forventede standarden. Han klarte ikke å leve opp til forventningene om at menn som ville være ledere, måtte være veltalende og utstråle kraft og styrke. Han siterer hva han hadde hørt motstanderne si om ham: «'Brevene er myndige og sterke', sier noen, 'men når han kommer selv er han spak [asthenēs], og det han sier, er lite å bry seg om’» (2 Kor 10, 10). Funksjonshemmingsteologen Amos Yong har antydet at Paulus kanskje var den første funksjonshemmede teologen (Yong, 2011, s. 83-85). Selv om mange har spekulert i hva denne «tornen i kroppen» kan ha vært - nedsatt syn, 
epilepsi, talevansker, psykiske lidelser - sier ikke brevene nok til at vi kan trekke konklusjoner (Solevåg, 2018, s. 111-112). Det er kanskje heller ikke det viktigste. Det som er interessant, er om denne kroppslige erfaringen har preget hans tro og teologi. Både i første og andre korinterbrev argumenterer Paulus for en positiv forståelse av svakhet og uforstand som snur opp ned på datidens kulturelle forestillinger. Som konklusjon på fortellingen om tornen sier han: «Og derfor er jeg fylt av glede når jeg for Kristi skyld er svak, blir mishandlet, er i nød, i forfølgelser og i angst. For når jeg er svak, da er jeg sterk» (2 Kor 12, 10). Også visdom anses som en negativ verdi som byttes ut med dårskap, altså dumhet (1 Kor 1, 18-31), vanvidd og uforstand (2 Kor 11, 16-23). For Paulus er budskapet om frelse gjennom Jesu død på korset et budskap som har snudd alt på hodet. Det er et tegn på at Gud foretrekker det svake framfor det sterke og det det dumme framfor det vise: «[...] det som i verdens øyne er dårskap, det utvalgte Gud for å gjøre de vise til skamme, og det som i verdens øyne er svakt, det utvalgte Gud for å gjøre det sterke til skamme (1 Kor 1, 27). Yong bruker Paulus til å formulere en inkluderende kirkeforståelse der mennesker med funksjonsnedsettelser må forstås som kjernen i Guds folk (Yong, 2011, s. 95).

\section{Oppsummering}

I dette kapitlet har jeg vist hvordan funksjonshemming kan brukes som et perspektiv for å tolke Bibelen. Jeg har utforsket relasjonen mellom helse og frelse i noen utvalgte tekster i Det nye testamentet, og jeg har drøftet disse ut fra et funksjonshemmingsperspektiv. Tekstene berører spørsmål om hvorvidt helbredelse krever tro, og i så fall fra hvem, og om nedsatt funksjonsevne er et resultat av synd eller ikke. Videre reiser tekstene spørsmålet om funksjonsnedsettelse er noe som skal bli visket ut i det evige livet, eller om kroppen vil framstå med visse merker etter oppstandelsen.

Ingen av disse spørsmålene gir Det nye testamentet entydige svar på. Jeg har forsøkt å vise at det ikke bare er underfortellingene i evangeliene som berører spørsmål knyttet til funksjonshemming, men at også andre tekster er relevante, for eksempel referansene til Jesu oppstandelseskropp og Paulus sine tanker om verdien av den svake kroppen. I det mangfoldet 
av tekster som finnes i Bibelen, kan vi høre forskjellige stemmer som gir ulike innspill til en funksjonshemmingsteologi. En betegnelse jeg har brukt på dette mangfoldet, er polyfoni - flerstemthet (Solevåg, 2018, s. 153-154). Med det mener jeg at tekstene til sammen løfter fram ulike perspektiver og aspekter, som alle er viktige. Og kanskje er det nettopp i dette mangfoldet verdien ligger, fordi det speiler mangfoldige livserfaringer og mangfoldige kropper.

\section{Referanser}

Anderson, P. N. (2011). The riddles of the Fourth Gospel. An introduction to John. Minneapolis, MN: Fortress Press.

Avalos, H. (2007). Redemptionism, rejectionism, and historicism as emerging approaches in disability studies. Perspectives in Religious Studies, 34, 91-100.

Avalos, H., Melcher, S. J. \& Schipper, J. (2007). This abled body. Rethinking disabilities in biblical studies. Atlanta, GA: SBL Press.

Betcher, S. V. (2013). Disability and the terror of the miracle tradition. I S. Alkier \& A. Weissenrieder (Red.), Miracles revisited. New Testament miracle stories and their concepts of reality (s. 161-182). Berlin: De Gruyter.

Bibelen. (2011). Oslo: Det norske bibelselskap.

Carter, W. (2011). 'The blind, lame and paralyzed' (John 5:3): John's gospel, disability studies and postcolonial perspectives. I C. R. Moss \& J. Schipper (Red.), Disability studies and biblical literature (s. 129-150). New York: Palgrave MacMillan.

de los Reyes, P. \& Mulinari, D. (2005). Intersektionalitet: Kritiska reflektioner över (o)jämlikhetens landskap. Stockholm: Liber.

Eiesland, N. L. (1994). The disabled God. Toward a liberatory theology of disability. Nashville, TN: Abingdon Press.

Garland-Thomson, R. (1997). Extraordinary bodies. Figuring physical disability in American culture and literature. New York: Columbia University Press.

Gosbell, L. (2018). The poor, the crippled, the blind and the lame. Physical and sensory disability in the Gospels of the New Testament. Tübingen: Mohr Siebeck.

Graumann, L. A. (2013). Monstrous births and retrospective diagnosis. I C. Laes, C. F. Goodey \& M. Lynn Rose (Red.), Disabilities in Roman antiquity. Disparate bodies. A capite ad calcem (s. 181-210). Leiden: Brill.

Hull, J. M. (2001). In the beginning there was darkness. A blind person's conversation with the Bible. London, England: SCM Press.

Kartzow, M. B. (2012). Destabilizing the margins: An intersectional approach to early Christian memory. Eugene, OR: Pickwick. 
Koosed, J. L. (2017). Psalms, Lamentations, and Song of songs. I S. Melcher, M. Parsons \& A. Yong (Red.), The Bible and disability (s. 189-214). Waco, TX: Baylor University Press.

Lawrence, L. J. (2013). Sense and stigma in the Gospels. Depictions of snsory-disabled characters. Oxford, England: Oxford University Press.

Lawrence, L. J. (2018). Bible and Bedlam. Madness, sanism and New Testament interpretation. London, England: Bloomsbury T\&T Clark.

Marx-Wolf, H. \& Upson-Saia, K. (2015). The state of the question: Religion, medicine, disability and health in late antiquity. Journal of Late Antiquity, 8 (2), 257-272.

Melcher, S. J., Parsons, M. C. \& Yong, A. (Red.) (2017). The Bible and disability. A commentary. Waco, TX: Baylor University Press.

Metzger, J. (2010). Disability and the marginalisation of God in the parable of the snubbed host (Luke 14.15-24). The Bible and Critical Theory, 6(2), 23.21-23.15.

Mitchell, D. T. \& Snyder, S. L. (2001). Narrative prosthesis. Disability and the dependencies of discourse. Ann Arbor, MI: University of Michigan Press.

Moss, C. R. (2011). Heavenly healing: Eschatological cleansing and the resurrection of the dead in the early Church. JAAR, 79(4), 991-1017.

Moss, C. R. (2017). Mark and Matthew. I S. J. Melcher, M. C. Parsons \& A. Yong (Red.), The Bible and disability. A commentary (s. 275-302). Waco, TX: Baylor University Press.

Moss, C. R. \& Schipper, J. (2011). Disability studies and biblical literature. Basingstoke, England: Palgrave Macmillan.

Nutton, V. (2004). Ancient medicine. London, England: Routledge.

Olyan, S. M. (2008). Disability in the Hebrew Bible. Interpreting mental and physical differences. New York: Cambridge University Press.

Parsons, M. C. (2006). Body and character in Luke and Acts. The subversion of physiognomy in early Christianity. Grand Rapids, MI: Baker Academic.

Raphael, R. (2009). Biblical corpora: Representations of disability in Hebrew biblical literature. London, England: Continuum.

Schipper, J. (2006). Disability studies and the Hebrew Bible. Figuring Mephibosheth in the David story. New York: T\&T Clark.

Schipper, J. (2011). Disability and Isaiah's suffering servant. Oxford, England: Oxford University Press.

Schipper, J. (2017). Joshua-Second Kings. I S. Melcher, M. Parsons \& A. Yong (Red.), The Bible and disability: A commentary (s. 93-120). Waco, TX: Baylor University Press.

Solevåg, A. R. (2013). Et skeivt blikk på den merkede kroppen: Perspektiver fra funksjonshemmingsstudier og skeiv teori. I G. Buch-Hansen, M. Bjelland Kartzow \& A. R. Solevåg (Red.), Metodemangfold og Det nye testamentet: 
I fotsporene til den etiopiske evnukken (s. 125-143). Oslo: Cappelen Damm Akademisk.

Solevåg, A. R. (2018). Negotiating the disabled body. Representations of disability in early Christian literature. Atlanta, GA: SBL Press.

Solevåg, A. R. (2020). Zacchaeus in the Gospel of Luke: Comic figure, sinner and included 'other'. Journal of Literary and Cultural Disability Studies, 14(3), 225-240.

Turner, D. M. (2012). Disability in eighteenth-century England. Imagining physical impairment. Hoboken, NJ: Taylor and Francis.

Yong, A. (2011). The Bible, disability, and the Church: A new vision of the people of God. Grand Rapids, MI: Wm. B. Eerdmans Publishing. 


\title{
Helbredelsesforkynnelse og kristen tro
}

\author{
Knut Alfsvåg
}

VID vitenskapelige høgskole

\begin{abstract}
From the second half of the $19^{\text {th }}$ century, some Christians have maintained that by adeptly manipulating the relevant spiritual laws, one may liberate oneself entirely from physical illness. This article is an investigation of the doctrinal context and anthropological implications of this way of understanding the Christian message. The method of the investigation is textual analyses of the writings of some of the main representatives of this movement, like Essek Kenyon and Kenneth Hagin. The context is found to be an anti-elitist kind of modernity interpreted by means of the Wesleyan understanding of Christian perfection, and the implication is a kind of ableism with a one-sided emphasis on the well-being of the strong and physically healthy. The worldview is a type of mind-matter duality, where liberation from the limits of materiality is an important goal. One rejects the idea of the spiritual value of trials and tribulations and does not seem to have a message of hope for those who struggle with chronic illness.
\end{abstract}

Keywords: healing prophets, faith movement, ableism, Essek W. Kenyon, Fred Bosworth, William Branham, Kenneth Hagin

\section{Innledning}

I dette kapitlet skal jeg drøfte menneskesyn og virkelighetsforståelse i kristen helbredelsesforkynnelse. Fra og med andre halvdel av 180o-tallet opptrer en rekke helbredelsespredikanter som legger stor vekt på underfulle helbredelser som middel til å løse menneskers helseproblemer. Det innebærer at man forstår den perfekte kroppen som norm, og alle avvik 
fra denne normen ses på som et problem som trenger en løsning. Hvordan skal vi forstå tilblivelsen av en slik forkynnelsestradisjon, og hvordan skal den vurderes i lys av aktuell funksjonshemmingsteologi? Det er disse spørsmålene jeg vil prøve å svare på.

\section{Helbredelsesforkynnelse som teologisk problem}

Innenfor den kristne kirke har man alltid ment at det er en sammenheng mellom tro og helse (Porterfield, 2005). Både Jesus og apostlene drev en til dels oppsiktsvekkende helbredelsespraksis, og omsorg for syke ble helt fra starten av oppfattet som en viktig del av det diakonale oppdraget. Likevel har frigjøring fra somatisk sykdom ikke vært oppfattet som kjernen i det budskapet Jesus har gitt sin kirke. Det handler om seier over døden, ikke utsettelse av den. De oppdragsformuleringene alle evangeliene avsluttes med, retter derfor søkelyset mot dåp, opplæring og frelse fra synd, og tanken om kroppslig helbredelse spiller en forholdsvis perifer rolle i den utfoldelsen av Jesus-historiens betydning som gis i brevlitteraturen i Det nye testamente (NT). Nådegaver til å helbrede omtales i 1 Kor 12, men det refereres ellers ikke til noen slik tjeneste i menighetene. Jesus avviser eksplisitt at det skulle være noen entydig sammenheng mellom synd og sykdom. Det er heller slik at lidelsen gis en positiv funksjon som ramme rundt åpenbaring av Guds frelsende makt (Joh 9, 3). I NT har altså både lidelse og helbredelse en positiv funksjon. Det har derfor vært en konstant utfordring å skulle balansere disse elementene på en god måte, slik at man ivaretar den nytestamentlige forståelsen av sentrum og periferi i det kristne budskap.

Reformasjonen er et eksempel på hvordan man forsøkte å ivareta denne balansen. Da reagerte man med skepsis på den plass troen på underfulle helbredelser hadde fått i folkefromheten, hvor den var knyttet til både helgendyrkelsen og en tro på nattverdelementenes undergjørende effekt. Mest avvisende var Calvin, som mente at underfulle helbredelser var noe som bare forekom hos Jesus og apostlene. Dette kalles gjerne for «cessationism» («cessation» betyr «opphør») (Porterfield, 2005, s. 95); se også Mayhue (2003) og Grudem (1996). Luther var ikke så dogmatisk på dette punktet. Hos ham hadde forbønn for syke og en tro på (underfulle?) 
helbredelser fremdeles sin plass (Collver III, 2012). Begge ønsket imidlertid å befri de troende fra jakten på helbredelser som en form for gjerningsrettferdighet, og å flytte oppmerksomheten tilbake på det de oppfattet som kjernen i det nytestamentlige evangelium, nemlig budskapet om Guds ubetingede benådning uavhengig av sosial status, helsetilstand og sosial og moralsk yteevne. Betydningen av kirkens diakonale tjeneste ønsket de imidlertid å fastholde (Oftestad, 2011, s. 61-162).

Denne skepsisen til tanken om underfulle helbredelser blir imidlertid kraftig utfordret i løpet av det nittende århundre. Da får vi i flere miljøer en tro på at mennesker, enten ved såkalt positiv tenkning eller ved Guds underfulle inngrep, kan befris fra sykdommer som både gryende medisinsk ekspertise og tradisjonell folkelig visdom står hjelpeløse overfor. New Thought, Christian Science og romersk-katolsk valfart til Lourdes og andre helligsteder er eksempler på dette. Både Baer (2001, s. 737) og Porterfield (2005, s. 174-184) peker på dette som et allment trekk i denne perioden. Også teologer som oppfattet seg selv som relativt liberale, kunne viseinteresse for underfulle helbredelser (Mullin, 1989). I enkelte kristne vekkelsesmiljøer utfoldes dette som et budskap om at full legemlig helbredelse fra sykdom er en rettighet som står til de troendes disposisjon. Sykdom blir da en konsekvens av manglende tro. Slik helbredelsesforkynnelse finnes i både USA og Europa forut for og uavhengig av pinsevekkelsen, samtidig som den har en sterk og tydelig påvirkning på den. (En god oversikt på norsk foreligger i Lie, 2011b; opprinnelig publisert i Refleks, 2002). Den grundigste dokumentasjon av helbredelsesbevegelsens historie fram til 1930 har vi i trebindsverket av Robinson (2011-2014). I tiden etter andre verdenskrig har troshelbredelsesforkynnelsen igjen fått økt betydning (Harrell Jr., 1975; McConnell, 1988), og den er i dag et markant trekk i den pinsekarismatiske bevegelse i mange deler av verden (Porterfield, 2005, s. 172-174). En nyere bevegelse med likhetstrekk med det som her skildres, er New Apostolic Reformation (Snow, 2016). Ifølge Holmås (2018) har denne bevegelsen nå betydelig innflytelse i norske karismatiske miljer. Dette er også sentralt trekk ved trosforståelsen i karismatiske miljøer i Norge (Lie, 2011c). Troen på underfulle helbredelser har på denne måten blitt en viktig del av både norske trospraksiser og den globale kirkes trosuttrykk på en måte vi tidligere ikke har sett. 
Dette reiser flere viktige og interessante spørsmål. Når kristne gjennom historien har vært tilbakeholdne med konkrete løfter om helbredelse, henger det sammen med et bestemt syn på forholdet mellom Gud og menneske. Det er et troens privilegium å kunne legge fritt fram for Gud det som ligger en på hjertet. Det er ikke nødvendigvis en del av det samme privilegiet å holde seg med svært bestemte oppfatninger av hvordan Gud skal svare. Å knytte helbredelsen til menneskets evne til å innkassere det Gud alt har gjort ferdig, stiller også svært store krav til menneskets trosevne. Er dette en form for gjerningsrettferdighet? Hva med dem som ikke makter å prestere en slik tro, og som til og med får sin manglende trosevne demonstrert ved at de må kjempe med kroniske lidelser? Forutsetter helbredelsesforkynnelsen det som i dag gjerne omtales som ableisme, altså en forståelse av det funksjonsfriske mennesket som en antropologisk og sosial norm? Campbell definerer ableisme slik: «[A] belief that impairment or disability ... is inherently negative and should the opportunity present itself, be ameliorated, cured or indeed eliminated.... Disability then is cast as a diminished state of being human» (2009, s. 5). Er det et slikt menneskesyn helbredelsesforkynnelsen formidler? Og hva med det problemet at døden så langt har nådd alle, inkludert troshelbredelsesbevegelsens fremste forkjempere? Har det problemet en troverdig løsning på troshelbredelsens premisser? Lavik (2015) gir en interessant drøfting av et konkret eksempel på å leve med utfordringen fra helbredelsesforkynnelsen i møte med alvorlig sykdom.

For å komme nærmere et svar på disse spørsmålene skal jeg på de følgende sidene utfolde troshelbredelsesforkynnelsens læremessige innhold, forutsetninger og implikasjoner noe mer i detalj. Jeg holder meg da først og fremst til dem som normalt regnes som denne retningens viktigste ideologer, nemlig Essek W. Kenyon (1867-1948) (Lie, 2003), Fred Bosworth (1877-1958) (som i motsetning til Kenyon var virksom innen pinsebevegelsen), William Branham (1909-1965) (Weaver, 1987) og Kenneth Hagin (1917-2003) (Sannes, 2005; Hejzlar, 2010). Dette er autoriteter som vises til også i norske sammenhenger. Ifølge Lie (2011a, s. 485) ble en artikkel av Hagin første gang trykt i en norsk sammenheng i Aril Edvardsens blad Troens bevis i 1963. Kenyon er særlig viktig, ettersom 
han er bevegelsens grunnleggende ideolog som alle senere refererer til. Aril Edvardsen introduserte også Kenyon i Norge, blant annet etter en personlig helbredelsesopplevelse tidlig på 1960-tallet (Lie, 2011a, s. 487). Aril Edvardsen og arbeidet i Sarons dal var svært sentralt når det gjaldt å formidle den karismatiske fornyelsesbevegelsen til Norge (Lie, 2011a, s. 490-492). Fra 1980 ble det etablert selvstendige karismatiske menigheter i Norge(Lie, 2011a, s. 501). På 1980-tallet ble Åge Åleskjær viktig for formidlingen av Hagins tanker (Lie,2011a, s. 511-513). Ifølge McConnell (1988) siterer Hagin lange avsnitt fra Kenyons bøker uten kildeangivelse. Branham har en gruppe norske tilhengere med en egen webside, www. vekkelsen.no. Jeg legger mer vekt på å få fram det som er felles for disse og andre ledende representanter for bevegelsen, enn å analysere eventuelle forskjeller mellom dem.

\section{Helbredelsens tilgjengelighet}

Ifølge helbredelsesbevegelsens ideologer har troende krav på å bli befridd fra sykdom og fattigdom. Sykdom er derfor et tegn på ulydighet som det er mulig å unngå, sier Bosworth (1924, s. 57-58). Med henvisning til Salme 103, 3 sier Hagin at Gud har lovet å helbrede alle våre sykdommer, ikke bare noen av dem (Hagin, 1979, s. 19). Det avvises at sykdom og lidelse kan ha en positiv funksjon. Bosworth kaller en slik tanke for absurd. Hvis man virkelig mente det, burde man jo avvikle alle sykehus, mener han (Bosworth, 1924, s. 54-57). Dette er ikke ment som et angrep på helsevesenet, for både Bosworth og Hagin er takknemlige for det som skjer der, men de mener at det er en sekundærløsning for dem som ikke har nok tro (Sannes, 2005, s. 42-43). For troende er derfor sykehus egentlig unødvendig.

Dette er forankret i en bestemt oppfatning av Gud, Satan og mennesket og forholdet dem imellom. Skapelsen av mennesket framstilles hos Kenyon som en konsekvens av Guds lengsel etter noen han kunne ha fellesskap med - han ønsket sønner og døtre (Kenyon, 1964a, s. 23, opprinnelig publisert i 1916). Gudsbildet har altså svært menneskelige trekk. Den nære gudsrelasjonen ga Adam en innsikt som gjorde at han - i motsetning til Eva - forsto syndefallets konsekvenser. Han prioriterte bevisst 
sin kone framfor Gud, noe som i Guds øyne framtrer som et forræderi (s. 36). Han mistet derfor sin delaktighet i Gud og fikk djevelen som sin åndelige far (s. 38-41). Dermed ble hans kropp underlagt sykdom og død, og dette ble arvet av hans etterkommere (s. 42). Samtidig gikk det herredømmet over verden som Adam utøvde på Guds vegne, over til hans nye mester. Satan er dermed «denne verdens gud» (jf. 2 Kor 4, 4). Bundet av sin rettferdighet må Gud etter Kenyons oppfatning vedstå seg den kontrakten han inngikk med Adam, om å la ham herske over verden også når Adam gir denne retten videre til sin nye herre. Gud kan derfor ikke bruke sin allmakt til å bekjempe Satan direkte (Kenyon, 1964a, s. 38; se også Lie, 2003, s. 40). Dette er også et svært sentralt poeng hos Hagin (Sannes, 2005, s. 66-68).

Inkarnasjonen oppfatter Kenyon som forutsetningen for den indirekte løsningen som Gud da måtte velge. Fordi Kristus er både Gud og et menneske som er unnfanget uten manns medvirkning, unngår han å bli et menneske som tjener Satan, slik Adams etterkommere gjør. Han kunne derfor leve et liv etter Guds vilje (Lie, 2003, s. 42). Det viktigste han gjorde, var imidlertid å ta på seg straffen for Adams synd ved selv å dø åndelig og overta den falne menneskenatur under Satans herredømme (s. 43). Dette er den såkalte JDS-læren, eller «Jesus died spiritually», som har vært gjenstand for mye diskusjon. Hagin følger Kenyon også her; se Hejzlar (2010, s. 75-77) og Atkinson (2007). Da Satan tok Kristus med seg til helvete, maktet imidlertid Kristus å beseire ham, og Kristus tok dermed tilbake den retten til å herske over verden som Adam hadde før syndefallet. Jesus er derfor den første som er gjenfødt (Hagin, 1983, s. 30). På denne måten blir Kristi seier over Satan forbilledlig for den seieren enhver troende skal vinne. Gud aksepterte dessuten Kristi død som et offer for menneskenes synder (Sannes, 2005, s. 95-96). Forsoningen er dermed fullbrakt, og forutsetningen er til stede for at alle mennesker skal få oppleve det gudsfellesskapet Adam hadde før syndefallet, noe som etter Kenyons oppfatning innebærer frelse fra både synd og sykdom (Lie, 2003, s. 44).

Dette foreligger imidlertid bare som en rettighet. Det gjenstår at rettighetshaverne gjør krav på sin rett. Å tilegne seg frelsens mulighet er altså til sjuende og sist menneskets eget ansvar. I kraft av forsoningen 
er menneskets natur fornyet, slik at mennesket igjen er delaktig i Guds åndelighet. Hagin kan omtale dette som en parallell til inkarnasjonen i Kristus (Sannes, 2005, s. 89-90). Den verdenen vi lever i, er imidlertid fremdeles underlagt Satans herredømme, og fordi menneskenes sinn gjennom deres fysiske sanser og det de oppfatter, fremdeles er sterkt preget av verden, gjenstår det en kamp for at menneskets guddommelige natur skal gjennomtrenge dets sinn. Dette kaller Kenyon helliggjørelse (Lie, 2003, s. 45). Mennesket seirer i denne kampen ved at det aktivt tar i bruk den retten til frihet fra synd og sykdom som foreligger, i og med Kristi seier over Satan. Med bønn i Jesu navn kan man binde Satan og hans tjenere slik Jesus gjorde, og dermed frigjøres fra deres makt. Retten til å bruke Jesu navn oppfattes som en fullmakt med omfattende rettigheter. Dette er et hovedpoeng i Hagin (1983; se også Sannes, 2005, s. 77-79). Ifølge Branham betyr dette at også dåp skal forrettes i Jesu navn, ikke i den treenige Guds navn (Branham, u.å.b). Angende Branhams forhold til den skalte Oneness Pentecostalism, se Alfsvåg, 2014, s. 41-42. Retten ble første gang tatt i bruk pinsedag, selv om det er Kenyons oppfatning at det var Paulus som først forsto fullt ut hva dette innebar. Dette er et hovedpoeng i Kenyon (1964b; opprinnelig utgitt i 1945). Denne preferansen for Paulus innebærer at evangeliene, inkludert Fadervår og Bergprekenen, gjelder troende under den gamle pakten, og at de ikke uten videre kan anvendes av kristne. Da Åge Åleskjær gjorde slike tanker gjeldende i sin bok Fullstendig frihet (Åleskjær, 2004), ble han kritisert for ikke å ta lovens krav på alvor, og det ble atskillig strid om dette innenfor den norske trosbevegelsen (Lie, 2011a, s. 517-518). For Hagin innebærer de troendes fullmakt også makt over døden, i den forstand at de troende selv kan bestemme sin livslengde (Sannes, 2005, s. 121).

Gjennomgående oppfattes dette slik at man må tro på den åndelige naturs seier til tross for sansenes vitnesbyrd om sykdom og Satans makt. Bosworth setter dette på spissen og hevder at Gud har gjort vår tro til en betingelse for å oppfylle sine løfter (Hejzlar, 2010, s. 98). Hagin understreker det samme og hevder at vi her må ha Gud som forbilde (Sannes, 2005, s. 103-105). Hagin bygger dette blant annet på sin fortolkning av Mark 11, 22, som han ikke forstår som en oppfordring til å tro på Gud, men til å ha samme tro som Gud. Da han skapte verden, trodde Gud at det han 
sa, ville skje, og slik gikk det. På samme måte må troende i dag tro at de maktordene de uttaler i Jesu navn, bringer den virkeligheten de utsier. Det innebærer at man må overse de symptomene på sykdom som sansene vitner om, og handle som om de ikke er der (Hejzlar, 2010, s. 99-100; Sannes, 2005, s. 106-107). De som ikke makter dette, er under Satans herredømme, og det er ingen annen hjelp å gi dem enn å bringe dem budskapet om Kristi fullstendige og forbilledlige seier over synd og sykdom.

\section{Helbredelsesforkynnelsens teologiske og ideologiske forutsetninger}

Helbredelsesforkynnelsen hos Kenyon og hans etterfølgere bygger altså på en tydelig dualistisk virkelighetsforståelse. Den fysiske verdenen vi nå lever i, er av det onde - den er underlagt Satans herredømme. Fornyelsens mulighet er imidlertid gitt i og med Jesu seier over synd og sykdom. Realiseringen av denne seieren består da i en kamp for å la de åndelige realiteter, altså makten i Jesu navn som i prinsippet er gitt alle troende, beseire den verdenen som er fanget av synd og sykdom som sansene tar inn. Antropologien blir da tredelt; den i prinsippet frigjorte natur, kroppen merket av synd og sykdom samt menneskets sinn eller ånd, hvor kampen mellom de to står.

Det er lett å se parallellene til bevegelser som Christian Science og New Thought, som legger stor vekt på tenkningens betydning for menneskets helse. McConnell fremhever denne tilknytningen som en nøkkel til å forklare Kenyons tenkning (McConnell, 1988). Lie er skeptisk til McConnells analyse, og mener at han legger for lite vekt på Kenyons kritikk av New Thought (Lie, 2003, s. 64-66). Det både McConnell og Lie etter min oppfatning legger for lite vekt på, er parallellen mellom helbredelsesforkynnelsen og den allment utbredte virkelighetsforståelsen i moderniteten. Dette er generelt en tid som er sterkt preget av troen på menneskeåndens evne til å underlegge seg naturen og gjøre seg nytte av den. Ny teknologi ble tatt i bruk og åpnet muligheter ingen tidligere hadde tenkt på. Det sterke og friske mennesket blir norm og ideal, jf. Newell (2010, s. 173). Parallelt med dette får vi den spede begynnelsen av moderne, vitenskapsbasert medisin. Enn så lenge var det imidlertid en 
tilnærming som gjorde at man kunne ane muligheter den enda var langt unna å realisere. Troen på at det fantes andre livslover som lot seg utnytte via en annen metode enn den som ble utforsket i laboratoriene, var da lett å gripe til. Baer (2001, s. 760-762) legger stor vekt på helbredelsesforkynnelsen som alternativ virkelighetsforståelse. Helbredelsesforkynnelsens ledere var alle overbevist om de underfulle helbredelsenes realitet, og om den akademiske vitenskapen ikke kunne forklare dem, var det nærliggende å lete etter andre modeller. Kravet om erfarbar entydighet består imidlertid som et tydelig fellestrekk mellom helbredelsesforkynnelsen og moderniteten og lar helbredelsesforkynnelsen, til tross for dens preg av antielitisme, fremstå som en tydelig moderne bevegelse som gjør det sterke menneskets uhemmede utfoldelse til norm, og som tror at dette er noe som lar seg realisere. Det antielitistiske er enda tydeligere i New Apostolic Reformation, som tolker kampen for det åndelige herredømmet i politiske kategorier i mye større grad enn helbredelsesbevegelsen (se Snow, 2016).

Helbredelsesbevegelsen trengte altså en teologisk modell som på en adekvat måte kunne fortolke det man oppfattet som Åndens entydige manifestasjoner i form av underfulle helbredelser. Denne modellen fant helbredelsespredikantene i tradisjonen etter John Wesley (1703-1791), opphavsmann til den metodistiske vekkelsesbevegelsen. Dette er en sammenheng som vektlegges av flere, blant andre Baer (2001, s. 735-736) og Robinson (2011, kap. 3 og 4). Ifølge Wesley kan kristne gjennom sin kamp for helliggjørelse bekjempe synden, og ved Åndens ledelse kan de nå fram til fullkommenhet («perfection»), noe som ble en viktig del av det teologiske grunnlaget for pinsebevegelsens åndsdåpsteologi (Maddox, 1999). Wesley selv later ikke til å ha vært spesielt opptatt av helbredelse, selv om han nok så det som en mulighet (Porterfield, 2005, s. 167). Han er imidlertid sterk tilhenger av å fremstille Åndens nærvær i den troendes liv som en erfarbar realitet. Selv om han primært oppfattet dette i moralske kategorier som seier over synd, var det en nærliggende modell å gripe til når man sto overfor utfordringen med å skulle gi en teologisk fortolkning av de underfulle helbredelser man opplevde. Wesleys helliggjørelsesteologi ble da omtolket til en lære om Åndens seier, ikke bare over synden, men også over ondskapens manifestasjon i form av legemlig sykdom. 
Helbredelsesforkynnelsen fremmer altså en dualisme som fortolker helbredelser som uttrykk for Åndens entydig erfarbare nærvær. Bevegelsen fremstår som moderne, både ved at den vektlegger en erfarbar entydighet som lar seg forstå og bearbeide av dem som kjenner livslovene, og ved at den forstår det funksjonsfriske mennesket som antropologisk norm. Samtidig er den alternativ og vitenskapskritisk ved å fremheve bønn i Jesu navn som den sakssvarende metoden for å oppnå de positive effektene den er ute etter å fremme.

\section{Helbredelsesforkynnelsens bibelforståelse og gudsbilde}

Helbredelsesforkynnerne ønsker å ta de bibelske løftene om bønn på alvor. «Be, så skal dere få» er en viktig bibeltekst (Matt 7, 7), og helbredelsesforkynnerne ønsker å ta Jesus på ordet. Denne viljen til konkret og bokstavelig bibeltolkning fastholdes uten innskrenkning i møte med de bibelske løftene om frelse fra både sykdom og synd. Både Salme 103,3 («han leger alle dine sykdommer») og Jes 53, 4 («våre sykdommer tok han») forstås da som utsagn om frelse fra somatisk sykdom, selv om Det nye testamente forstår disse tekstene annerledes (Kartveit, 2000).

Hvordan skal vi forstå referansen for de bibelske metaforene for guddommelige inngrep til frelse? I den oldkirkelige læren om theosis var det viktig å fastholde tanken om Guds reelle, frelsende nærvær uten å hevde at det på en enkel og entydig måte kunne knyttes til bestemte fenomener eller opplevelser (Wittung \& Christensen, 2007). Det er moderniteten, altså den allment utbredte virkelighetsforståelsen fra og med opplysningstiden, som stiller det kravet at Guds nærvær må være konkret og entydig for å være reelt. Kristen teologi stilles da overfor dilemmaet med at den må velge mellom å identifisere Gud med konkrete erfaringer, eller å benekte at Gud på modernitetens premisser i det hele tatt kan være nærværende. Nyere protestantisk teologi har strevd mye med dette problemet (Alfsvåg, 2016b, s. 206-207).

1700-tallets vekkelsesbevegelser - pietisme og metodisme - svarer på utfordringen ved å knytte gudsnærværet til entydige erfaringer av helliggjørelse. Dette kan kombineres med en forståelse av den tradisjonelle 
teologiens tilbakeholdenhet overfor det konkret verifiserbare som en tilbaketogsstrategi. Når tradisjonell teologi avviser å identifisere Gud med verifiserbare observasjoner av det skapte, er det fordi man ikke tør ta de bibelske formuleringene på alvor. Helbredelsesbevegelsen tar dette et viktig skritt videre ved å fortolke erfaringer av helbredelser som konkrete eksempler på guddommelig nærvær, og dermed som en bokstavelig oppfyllelse av de bibelske løftene om frelse fra sykdom. Dette er en radikalisering av den wesleyanske helliggjørelseslæren, hvor anvendelsen er medisinsk, ikke moralsk.

Når man slik insisterer på at referansene for de bibelske beskrivelsene av Guds nærvær og Guds gjerninger skal forstås så konkret som mulig, blir resultatet et gudsbilde med tydelig antropomorfe (menneskelignende) trekk. Riktignok kan Gud til en viss grad tenkes som allmektig (Sannes, 2005, s. 71), men han er ikke allestedsnærværende (s. 125). Han skaper mennesket som en konsekvens av sin lengsel etter fellesskap, og han inngår kontrakter og er bundet av avtaler og de generelle livslovene i den åndelige verden.

Her skiller helbredelsesforkynnelsen seg markant fra førmoderne teologi, som legger til grunn at det prinsipielle skillet mellom Gud og den skapte verdenen som er Bibelens grunnleggende utgangspunkt (jf. 1 Mos 1, 1), innebærer at gudspredikater hentet fra menneskers erfaring (og av gode grunner er det ikke noe annet sted å hente dem fra), aldri kan anvendes direkte på Gud. Utsagn med Gud som referanse er derfor alltid i en viss forstand billedtale. Det bibelske forbudet mot å gjøre seg noe bilde av Gud (2 Mos 20, 4) oppfattes på disse premissene også som et forbud mot å oppfatte språklige gudsbildene som noe annet og noe mer enn antydninger som ikke må forveksles med den realiteten de prøver å peke mot.

For eksempel vil bibelske utsagn om «Guds trone» normalt bli oppfattet som uttrykk uten konkret referanse, fordi Guds trone er overalt hvor han gjør sin makt gjeldende, det vil si i hele skaperverket. Hagins hermeneutiske og virkelighetsteoretiske forutsetninger gjør at han må forstå «Guds trone» som et lokaliserbart sted (Hagin, 1983, s. 37). Dette minner om Calvins kristologi, som benekter Jesu allestedsnærvær etter hans menneskelige natur (Hägglund, 1975, s. 242), men Hagin går lenger enn 
dette. Når gudsutsagn får en konkret referanse, blir Gud altså et vesen som er lokaliserbart og underlagt de lover som gjelder for all virkelighet. Riktignok tenkes han å ha en slags åndelig eksistens, men han er like fullt en del av den virkeligheten som omfatter alt som fins. Dette kan formuleres som en generell påstand: Når man insisterer på de bibelske metaforenes konkrete, erfarbare betydning, blir resultatet antropomorfisme i gudsforståelsen og dualisme i virkelighetsforståelsen, mens førmoderne teologi, som forstår Gud som forskjellig fra, men dermed også som nærværende i, all virkelighet, verken er dualistisk, antropomorf eller entydig. For eksempel er en typisk førmoderne teolog som Marti Luther ambivalent overfor den naturlige gudserkjennelse (Alfsvåg, 2016a). Det vil alltid hefte en ambivalens ved forståelsen av den evige som nærværende i tid og rom, og av Gud som Herre over en verden rammet av syndens konsekvenser. Dette er et vesentlig poeng i Bibelens klagesalmer. Til gjengjeld har man da muligheten for å forstå Gud som nærværende i alt som skjer, også når det onde ikke oppleves som overvunnet og beseiret.

Betydningen av det som her er anført, ligger blant annet i at det styrer forståelsen av hva det er som skjer når vi ber. Etter helbredelsesforkynnelsens oppfatning består bønn i å manipulere allmenngyldige livslover som også Gud er underlagt, i den hensikt å bekjempe det gode og fremme det onde. Gud blir da en tjener for det mennesket som har så god innsikt i de åndelige lover at vedkommende makter å gjøre seg nytte av dem. Her er det relevant å peke på Hagins utsagn om å få Gud til å arbeide for seg (Sannes, 2005, s. 125). Også Kartveit (2000, s. 257-258) påpeker hvordan Hagins forståelse av bønn avviker fra den nytestamentlige. Men om referansen for ordet «Gud» - i samsvar med førmoderne teologi - oppfattes som noe som står utenfor verden og ikke er underlagt tidens og rommets begrensninger, endres bønn fra å være et middel til manipulering til å bli et middel for å innrette seg selv etter de rammer Gud har satt for livet og virkeligheten. Bønn opphever da ikke verdens ambivalens, men lærer en å leve med den. Det utelukker ikke muligheten for å legge fram for Gud de problemer en selv og andre strever med, inkludert somatisk og psykisk sykdom, og det utelukker heller ikke muligheten for at man kan forvente at problemene kan ha en løsning. Men det utelukker muligheten for å foreskrive for Gud hva han kan og bør gjøre for å realisere idealet 
om det funksjonsfriske, problemfrie mennesket. Jesu bønn i Getsemane, «ikke som jeg vil, men som du vil» (Matt 26, 39), blir da det definerende kjennetegnet på rett kristen bønn, og bønnen blir et middel til alltid å oppfatte det man opplever som et uttrykk for Guds gode vilje, ikke som et middel til å manipulere de åndelige lover slik at de gir de resultatene man synes man har krav på. Når det gjelder Hagins forståelse av Matt 26,39, se Sannes (2005, s. 109).

Helbredelsesforkynnelsen er opptatt av det kompetente, sterke og friske mennesket. Målet er å ha en slik innsikt i - og en slik evne til å manipulere - de åndelige livslovene at man kan heve seg over fysiske begrensninger knyttet til sykdom og helse, og realisere det frie liv ubundet av slike hindringer. Dette svarer godt til den definisjon av ableisme som jeg allerede har gitt med referanse til Campbell (2009). Flere har pekt på at dette er et menneskesyn som avviker sterkt fra det vi finner i Det nye testamente, hvor vekten legges på å skape et fellesskap som inkluderer alle, på tross av både åndelige og fysiske mangler (Eiesland, 1994; Yong, 2015; Gaventa, 2018). Overfor dette idealet kommer helbredelsesforkynnelsen helt klart til kort.

Noen vil overfor en slik kritisk konklusjon innvende at helbredelsesforkynnelsen har gitt håp, oppreisning og legemlig sunnhet til mennesker som ellers måtte ha klart seg uten. Det er to ting å si til et slikt argument. For det første er det motsatte utvilsomt også riktig. Helbredelsesforkynnelsens fokus på menneskets ansvar for sin egen helbredelse har helt klart medført store belastninger for mennesker som strever med kronisk sykdom. Det har blant annet vært en del oppmerksomhet rundt barn som dør av medisinske tilstander som kan behandles, fordi foreldrene insisterer på troshelbredelse (Guzder, 2009). Helbredelsespredikantenes budskap er derfor ikke bare teologisk, men også moralsk uholdbart. For det andre er det slik at om det skulle skimtes et element av genuin bibelsk håpsforkynnelse også gjennom helbredelsespredikantenes virksomhet, så skyldes det at de også formidler deler av et bibelsk evangelium de ellers ikke har forstått eller tilegnet seg. Budskapet om den tomme grav innebærer ifølge Det nye testamente et håp om utfrielse fra både synd, sykdom og død. Å formidle dette på en måte som gir et helende livsperspektiv for mennesker som strever, er utvilsomt en av den kristne kirkens viktigste oppgaver, 
og det er heller ingen tvil om at dette har positiv betydning for mange. Dette er et vesentlig poeng i Poerterfield (2005). Men det innebærer ingen fullmakt til å sette Gud i arbeid på premisser mennesker har avdekket, og det innebærer heller ingen rett til å problematisere at vi ikke fullt ut får oppleve evangeliets helende potensiale på denne siden av døden.

\section{Konklusjon}

Helbredelsesforkynnelsen fremstår altså som en bevegelse med nær tilknytning til modernitetens preferanse for det konkrete og det erfarbare, men med en alternativ forståelse av de lovene som virkeligheten på disse premisser tenkes å være underlagt. Det alternative kan settes i søkelyset i så stor grad at de naturlovene vitenskapelig forskning avdekker, kan oppfattes som uttrykk for Satans verdensherredømme, og derfor ikke som en del av Guds opprinnelige skaperverk (Sannes, 2005, s. 69). Den norske helbredelsespredikanten Svein-Magne Pedersen demoniserer ikke vitenskapelig medisin, men er tydelig på forståelsen av «de åndelige lovene» som et parallelt alternativ (Pedersen, u.å.).

Helbredelsesforkynnelsen er likevel en moderne bevegelse i den forstand at den legger stor vekt på å kunne manipulere virkeligheten ved å formulere entydige utsagn om hvordan den henger sammen. Ut fra den vekten som en slik virkelighetsforståelse generelt har i vår tid, er det nærliggende å se på helbredelsesforkynnelsen som en form for kontekstualisering. Det blir imidlertid en kontekstualisering hvor konteksten dominerer i den grad at budskapet blir borte. Den bibelske tilliten til Guds inkluderende kjærlighet som frelsesgrunn og livsideal erstattes av et krav om at vår tids troende må kunne manipulere de åndelige livslover til sin egen fordel.

Helbredelsesforkynnelsen har imidlertid ikke dekning for påstanden om at konsekvensen av Jesu død og oppstandelse er at alle troende kan innkassere oppstandelsens frukter i form av et liv fritt for somatisk sykdom. Verken apostlene eller kirkens klassiske tenkere forstår det slik. Helbredelsesforkynnelsens forståelse forutsetter derfor en systematisk omtolkning av alle bærende elementer i den virkelighetsforstålsen som i NT og tradisjonell kristendom er ramme for fortolkning av Jesu liv, død 
og oppstandelse. Konsekvensen er en ekstrem arminianisme (viljefrihetslære), hvor hele vekten ligger på menneskets evne til å skaffe seg innsikt i de livslovene som ligger til grunn for den bibelske fortelling, og hvor Jesu evne til å gjøre seg nytte av disse livslovene til eget og andres beste oppfattes som forbilledlig. At prøvelser etter NTs oppfatning kan formidle både tålmodighet og håp (Rom 5,3-4), er et perspektiv som faller helt utenfor. I stedet formidles det et budskap om de krav og forventninger mennesker må tilfredsstille for å kunne leve et liv som fullt ut utnytter de overleverte muligheter for innsikt i og manipulasjon av de åndelige livslover. Dette er imidlertid ikke å kontekstualisere det kristne evangelium - det er å erstatte det med et annet budskap.

\section{Referanser}

Alfsvåg, K. (2014). Hva vi er, har Gud vært, og hva Gud er, skal vi bli. Kritikk av treenighetslæren i mormonismen, Oneness Pentecostalism og trosbevegelsen. Theofilos, 6(2014), 38-47.

Alfsvåg, K. (2016a). Natural theology and natural law in Martin Luther. I D. Nelson \& P. Hinlicky (Red.), The Oxford research encyclopedia of Martin Luther. Oxford, NY: Oxford University Press.

Alfsvåg, K. (2016b). 'These things took place as examples for us': On the theological and ecumenical significance of the Lutheran Sola Scriptura. Dialog, 55, 202-209. https://doi.org/10.1111/dial.12256

Atkinson, W. (2007). The nature of the crucified Christ in word-faith teaching. Evangelical Review of Theology, 31(2), 169-184.

Baer, J. R. (2001). Redeemed bodies:The functions of divine healing in incipient Pentecostalism. Church History, 7o(4), 735-771.

Bosworth, F. F. (1924). Christ the healer: Sermons on divine healing. Chicago.

Branham, W. (u.å.a). Den første synd. Hentet fra http://themessage.com/no/ originalsin

Branham, W. (u.å.b). I navnet. Hentet fra http://themessage.com/no/ inthename? $\mathrm{mid}=28718$

Campbell, F. A. K. (2009). Contours of ableism: The production of disability and abledness. New York: Palgrave Macmillan.

Collver III, A. B. (2012). Fides heroica? Luther's prayer for Melanchthon's recovery from illness in 1540. Concordia Theologica Quarterly, 76, 117-127.

Eiesland, N. L. (1994). The disabled God: Toward a liberatory theology of disability. Nashville, TN: Abingdon Press. 
Gaventa, W. C. (2018). Disability and spirituality: Recovering wholeness. Waco, TX: Baylor University Press.

Grudem, W. A. (Red.) (1996). Are miraculous gifts for today: Four views. Grand Rapids, MI: InterVarsity Press.

Guzder, D. (2009). When parents call God instead of the doctor. Hentet fra http:// content.time.com/time/nation/article/o,8599,1877352,0o.html

Hagin, K. E. (1979). Seven things you should know about divine healing. Tulsa, OK: Faith Library.

Hagin, K. E. (1983). The name of Jesus. Tulsa, OK: Rhema Bible Church.

Harrell Jr., D. E. (1975). All things are possible: The healing and charismatic revivals in modern America. Bloomington, IN: Indiana University Press.

Hejzlar, P. (2010). Two paradigms for divine healing: Fred F. Bosworth, Kenneth E. Hagin, Agnes Sanford, and Francis MacNutt in dialogue. Leiden: Brill NV.

Holmås, G. O. (2018). Ved en korsvei: Åpent brev til mine karismatiske venner. Oslo: Luther.

Hägglund, B. (1975). Teologins historia: En dogmhistorisk översikt. Lund: Liber Läromedel.

Kartveit, M. (200o). Bruken av Bibelen i trusrørsla. Tidsskrift for teologi og kirke, 251-264.

Kenyon, E. W. (1964a). The father and his family: A restatement of the plan of redemption (17. utg.). Lynnwood: Kenyon's Gospel Publishing Society.

Kenyon, E. W. (1964b). New creation realities: A revelation of redemption. Lynnwood, WA: Kenyon's Gospel Publishing Society.

Lavik, M. H. (2015). «Forsvinn i Jesu namn!» - sjukdom, bibelbruk og impulsar frå global trusteologi. I A. Kalvig \& A. R. Solevåg (Red.), Levende religion: Globalt perspektiv - lokal praksis (s. 192-210). Stavanger: Hertervig Akademisk.

Lie, G. (2003). E. W. Kenyon - cult founder or evangelical minister? An historical analysis of Kenyon's theology with particular emphasis on roots and influences. Oslo: Refleks Publishing.

Lie, G. (2011a). Fra amerikansk hellighetsbevegelse til moderne norsk karismatikk: Et historisk overblikk. Oslo: Akademia forlag.

Lie, G. (2011b). Helbredelse ved tro: Fra Möttlingen til Tulsa. I G. Lie (red.), Fra amerikanske hellighetsbevegelse til moderne norsk karismatikk: Et historisk overblikk (s. 461-478). Oslo: Akademia forlag.

Lie, G. (2011c). Trosbevegelsen i Norge. I Geir Lie (Red.), Fra amerikansk hellighetsbevegelse til moderne norsk karismatikk: Et historisk overblikk (s. 479519). Oslo: Akademia forlag.

Maddox, R. L. (1999). Wesley's understanding of Christian perfection: In what sense Pentecostal? Wesleyan Theological Journal, 34(2), 78-110. 
Mayhue, R. L. (2003). Cessationism, 'the gifts of healings', and divine healing. The Master's Seminary Journal, 14(2), 263-286.

McConnell, D. R. (1988). A different gospel: A historical and biblical analysis of the modern faith movement. Peabody, MA: Hendrickson.

Mullin, R. B. (1989). Horace Bushnell and the question of miracles. Church History, $58(4), 460-473$.

Newell, C. (2010). On the importance of suffering: The paradoxes of disability. I H. S. Reinders (Red.), The paradox of disability: Responses to Jean Vanier and L'Arche communities from theology and the sciences (s. 169-179). Grand Rapids, MI: William B. Eerdmans Publishing.

Oftestad, A. B. (2011). Kirke - fellesskap - omsorg: Diakoniens historie del 2 og 3: Reformasjonstiden, ortodoksiens tid, pietismen, opplysningstiden. Oslo: Luther.

Pedersen, S.-M. (u.å.) Forbønn. Hentet 3.12.2019 fra http://www.mjl.no/?page_id=1204

Porterfield, A. (2005). Healing in the history of Christianity. Oxford, NY: Oxford University Press.

Robinson, J. (2011). Divine healing, the formative years, 1830-1890: Theological roots in the transatlantic world. Eugene, OR: Wipf and Stock Publishers.

Robinson, J. (2013). Divine healing: The holiness-Pentecostal transition years, 18901906: Theological transposition in the transatlantic world. Eugene, OR: Pickwick Publications.

Robinson, J. (2014). Divine healing: The years of expansion, 1906-1930: Theological variation in the transatlantic world. Eugene, OR: Wipf and Stock Publishers.

Sannes, K. O. (2005). Det guddommeliggjorte menneske og den menneskeliggjorte Gud: En analyse av Kenneth E. Hagins loere. Oslo: Refleks-publishing.

Snow, S. (2016). Prophets, demons, and witch hunts: American spiritual warfare as scapegoat ideology. Journal of Religion \& Society, 18, 1-23.

Weaver, C. D. (1987). The healer-prophet, William Marion Branham: A study of the prophetic in American Pentecostalism. Macon, GA: Mercer University Press.

Wittung, J. A. \& Christensen, M. J. (2007). Partakers of the divine nature: The history and development of deification in the Christian traditions. Madison, NJ: Fairleigh Dickinson University Press.

Yong, A. (2015). Disabilty, the human condition, and the spirit of the eschatological long run: Toward a pneumatological theology of disability. St Mark's Review, 232, $1-22$.

Åleskjær, Åge. (2004). Fullstendig frihet. Logos Forlag. 



\title{
Den desentrerte kirke: Et bidrag til disability-ekklesiologien
}

\section{Gyrid Gunnes}

VID vitenskapelige høgskole

\begin{abstract}
The chapter addresses the relationship between church/ecclesial practices and disability. Traditionally, disability ecclesiology focuses on how and in what way ecclesial practices contribute to the exclusion or inclusion of people living with various kinds of disability. The chapter takes as its starting point new trends in ecclesiological research by asking in what way non-ecclesial practice can be understood to be of relevance to ecclesiology. The example is Marte Wexelsen Goksøyr's performance of the poem "Voggesang for ein bytting" at the National Theatre in Oslo. This performance can be understood as the embodiment of a physical altar piece depicting Mary and Jesus with Down syndrome. I argue that this expression can be understood as a disability-sensitive decentred church.
\end{abstract}

Keywords: empirical ecclesiology, Marte Wexelsen Goksøyr, decentered church, disability, ecclesiology, inclusion

\section{Innledning}

Det finnes rikholdig teologisk refleksjon rundt kirken og dens praksiser ekklesiologi - og funksjonsnedsettelser (Eisland, 1994; Lid, 2016; Reynolds, 2008; Edøy, 2000; Njå, 2017). Sentrale spørsmål i disability-ekklesiologien er hvordan kirkelige praksiser har bidratt til diskriminering og utestenging av mennesker med nedsatt funksjonsevne, og hvordan dette kan endres. Hvilke bibelske metaforer bygger forestillinger om kirken på (eksempelvis kirken som «kropp»)? Hvordan forholder slike metaforer seg til det menneskelige mangfoldet som finnes blant levende kropper?

Sitering av denne artikkelen: Gunnes, G. (2020). Den desentrerte kirke: Et bidrag til disability-ekklesiologien. I I. M. Lid \& A. R. Solevåg (Red.), Religiøst medborgerskap: Funksjonshemming, likeverd og menneskesyn (Kap. 12, s. 249-267). Oslo: Cappelen Damm Akademisk. https://doi.org/10.23865/noasp.10o.ch12

Lisens: CC BY-NC-ND 4.0. 
Er kirkelige autoritetsposisjoner, eksempelvis presteembetet, tilgjengelig for mennesker med funksjonsnedsettelser?

Dette kapitlet er et bidrag til disability-ekklesiologien. Men det begynner ikke i disability-ekklesiologiens tradisjonelle spørsmål, slik de er skissert i avsnittet ovenfor. I stedet vil jeg begynne med spørsmålet: Er det gitt at disability-ekklesiologiens objekt er møtet mellom mennesker med funksjonsnedsettelser og de empiriske fenomenene som kalles «kirkelige», som kirkelige handlinger, bibelske metaforer og teologisk refleksjon? Kan man tenke på mennesker med funksjonsnedsettelsers handlinger i ikke-religiøse, sekulære rom - eksempelvis en teaterscene - som selvstendige bidrag til disability-ekklesiologien? Kapitlet vil derfor ta utgangspunkt i Trygve Wyllers utvikling av ideen om «den desentrerte kirke» (2017; Wyller \& Heimbrock 2019). Den desentrerte kirke er ifølge Wyller ikke den synlige kirken (det vil si den man gjennom samfunnsvitenskapelige metoder kaller «kirken»), men den usynlige kirkens empiriske manifestasjoner i verden. Dette perspektivet gjør ikke-kirkelige praksiser relevante for ekklesiologien. Å legge teorien om den desentrerte kirke til grunn for en disabiliy-ekklesiologisk utforsking åpner for en funksjonshemmingssensitiv desentrert kirke. En slik refleksjon synliggjør andre empiriske fenomener som relevante, enn dem som disability-ekklesiologien tradisjonelt har engasjert seg i. En disabilitysensitiv desentrert ekklesiologisk refleksjon gjør at handlingene til mennesker med funksjonsnedsettelser utenfor kirkerommet utfordrer disability-ekklesiologien og tilfører den et større tilfang av erfaringer. Jeg spør om Marte Wexelsen Goksøyrs fremføring av «Voggesang for ein bytting» på Nationaltheatret kan leses som et eksempel på en disability-sensitiv desentrert kirke. En slik tolkning leser Goksøyr som en iscenesettelse av Maria og Jesusbarnet hvor Maria er en kvinne med Downs syndrom. Fremføringen kan da leses som et stykke kontekstuell funksjonshemmingsteologi, hvor ulike aspekter ved spørsmålet om forholdet mellom funksjonsnivå og menneskeverd vises frem gjennom performativ handling.

I andre del av kapitlet drøfter jeg en disability-sensitiv desentrert kirke i lys av to aspekter ved tradisjonell disability-ekklesiologi, nemlig synet på inkludering og synet på autonomi i liturgi hos mennesker med kognitive funksjonsnedsettelser, særlig slik dette kommer til uttrykk i en artikkel av teologen Ådne Njå (2017). 


\section{Kirken som desentrert}

Innenfor ekklesiologien - læren om kirken - har det de siste to tiårene foregått en metodologisk vending mot å studere kirken som empirisk observerbare konkrete praksiser (Ward, 2012; Scharen, 2011; Ideström, 2015). En av dem som har problematisert den empiriske ekklesiologien, er Trygve Wyller (2017, 2019). Wyller hevder at den empiriske ekklesiologien blir så opptatt av spørsmål om metode at den - paradoksalt nok - glemmer ekklesiologien (Wyller \& Heimbrock, 2019). Men kan man samfunnvitenskapelig sett peke på den empiriske kirken og si «der er kirken»? Samfunnvitenskapelig kan man si at man må studere disse menneskene og disse stedene for å vite hva kirken og troende bedriver og mener. Men denne avgrensningen holder ikke i luthersk teologi. Ifølge CA VII ${ }^{1}$ er kirken der hvor det skjer en praksis, nemlig at evangeliet blir forkynt og sakramentene blir delt. Denne praksisen er aldri identisk med institusjonen, og den innebærer at kirkens medlemmer aldri er begrenset til de kontekstene som tradisjonelt identifiseres som «kirkelige». I empirisk ekklesiologi er derfor spørsmålet om epistemologi vel så viktig som spørsmålet om metode. Spørsmålet om hva som gjør et utsnitt av verden som relevant for empirisk feltstudier av den empirisk orienterte ekklesiologi-forskeren, er på ingen måte gitt. Konstruksjonen av et empirisk felt som relevant for empirisk ekklesiologi må i aller høyeste grad underlegges en ekklesiologisk refleksjon. En slik refleksjon vil hindre at empirisk ekklesiologi blir en blir vulgærekkesiologi hvor samfunnsvitenskapens forståelse av hva som er kirke og hvor den kan finnes empirisk, fortrenger teologiens nyansering av hva som regnes som kirke (eksempelvis fokus på praksis kontra institusjon i CA VII). Den usynlige kirken er en like virkelig og sann kirke selv om den ikke kan telles, måles eller beskrives gjennom et rent samfunnsvitenskapelig begrepsapparat. Den samfunnsvitenskapelige forståelsen av hva som er relevante data for å si noe om kirken, er ikke nødvendigvis overlappende med hva som er teologisk relevant. Metodespørsmål er med andre ord underordnet spørsmålet om epistemologi.

1 Se Den augsburgske bekjennelse (Confessio Augustana, CA), artikkel 7. 
Wyller tar skrittet fra vitenskapsteoretisk kritikk til konstruktive forslag for å forsøke å artikulere den usynlige kirkens manifestasjon i verden. Dette skjer gjennom en "re-ekklesiolofisering» av den empiriske ekklesiologien (Wyller, 2019). Dette forslaget kan kalles en «empirisk ekklesiologisk ekklesiologi» fordi den - etter Wyllers oppfatning - legger til grunn en teologisk forståelse av hvilke data som er relevante for å vite hva og hvor kirken rent empirisk sett er. Så hvor kan man finne den usynlige kirken som empirisk væren i verden? Ifølge Confessio Augustana er ikke kirken et spørsmål om medlemmenes beskaffenhet (enten de er «synlige» eller «usynlige» i menigheten eller i medlemsregisteret) men en performativ handling; kirken er der hvor evangeliets frigjøring og transformasjon forkynnes og sakramentene deles. En vektlegging av kirken som hendelse åpner for å anlegge et ekklesiologisk perspektiv på - potensielt - enhver mulig menneskelig praksis hvor evangeliets transformasjon og frigjøring skjer, uavhengig av om denne praksisen identifiseres av deltakerne selv eller av omverdenen som «kristen» eller «kirkelig». Wyller kaller en slik ekklesiologisk lesning av verden for «den desentrerte kirke». Den desenterte kirke er en empirisk synlig kirke, men denne synligheten blir bare synlig dersom forskeren legger til grunn en ekklesiologisk forståelse av hva som regnes som et relevant utsnitt av verden. Som tidligere beskrevet er ekklesiologisk synlighet for Wyller ikke primært et metodologisk spørsmål, men et spørsmål om hvilket hermeneutisk perspektiv forskeren anlegger. Forholdet mellom den empiriske kirkens synlighet som empirisk virkelighet og den usynlige kirkens empiriske manifestasjoner er heller ikke nødvendigvis konsentrisk eller overlappende. Med andre ord er ikke den usynlige empiriske kirke nødvendigvis en del av den synlige kirkens empiriske manifestasjon. Den kan like gjerne finnes helt andre steder og gjerne i direkte motsetning til kirken som organisasjon og institusjon.

\section{Eksempel på en disability-sensitiv desentrert kirke}

Hvis man anlegger et disabiliy-perspektiv på den empiriske ekklesiologien slik den fremtrer i tradisjonell empirisk ekklesiologi, finnes to typer 
feltarbeid som lett vil fremstå som selvfølgelige og forståelige for den kvalitativt orienterte ekklesiologisk forskeren. Den ene typen feltarbeid vil være knyttet til hvordan kirkelige praksiser som menigheter og kristne organisasjoner inkluderer eller ikke inkluderer mennesker med funksjonsnedsettelser i sine praksiser. Et eksempel på en slik studie er Mary McClintock Fulkersons studie (2007) av den amerikanske metodistmenigheten Good Samaritan. Et annet eksempel er Ådne Njås teologiske lesning av deltakelsen til mennesker med kognitive funksjonsnedsettelser i gudstjenester (Njå, 2017). En annet type feltarbeid kan være kirkelige praksiser som er bygd opp rundt ønsket om å fremme inkludering av mennesker med kognitive funksjonsnedsettelser. Eksempler på slike arenaer for empirisk feltarbeid kunne være Mariahuset i Oslo eller L'Arche i Frankrike. Inger Marie Lid og Leonora Onarheim Bergsjøs studie av Tomaskirken hos stiftelsen Signo (tidligere Hjemmet for døve) er et eksempel på en slik studie (Lid \& Bergsjø, 2017).

Slike studier er viktige for den akademiske refleksjonen rundt funksjonsnedsettelse som kontekst for ekklesiologisk refleksjon. Wyllers kritikk av empirisk ekklesiologi er ikke en kritikk av praksiser som Mariahuset, L'Arche eller Good Samaritan. Kritikken beveger seg på et erkjennelsesteoretisk nivå: det den kritiserer er faren i empirisk orienterte ekklesiologien for å kollapse det empiriske og det teologiske nivået med hverandre. Kritikken er derfor rettet mot den empiriske ekklesiologiske forskningen, inkludert disability-ekklesiologiske studier. Når den ekklesiologiske forskeren overtar allmennhetens forstillinger om hvilke steder som umiddelbart forstås som kirkelige, overses og undergraves det kreative potensialet ved teologien. For kanskje oppstår kirken, teologisk sett, helt andre steder enn der man allment kaller den for «kirke», også i disabilty-ekklesiologien?

Hvis man anlegger et disabiliy-perspektiv på Wyllers kritikk av tradisjonell empirisk ekklesiologi, innebærer dette at en empirisk tilnærming til ekklesiologisk refleksjon ikke bare vil orienteres mot menigheter og steder som Mariahuset og L'Arche. Det å lete etter den desenterte kirken i et disability-perspektiv vil innebære å vende forskerblikket mot alle steder i samfunnet hvor livskrefter og aktørskap fremmes. Disabilityekklesiologiens usynlige kirke - en disability-sensitiv desentrert 
kirke - er derfor, rent empirisk, alle steder hvor mennesker som lever med funksjonsnedsettelser, fremstår som subjekter med egne stemmer og kropper. Et forslag til en identifikasjon av Wyllers desentrerte kirke i et disability-perspektiv kan være Marte Wexelsen Goksøyrs opptreden på Nationaltheatret, der Goksøyr med et barn i armene fremfører diktet «Voggesang for ein bytting» av Halldis Moren Vesaas.

Bysse bysse stort stygt barn.

Troll blir du kalla med rette.

Digraste gryta må hengast i jarn

om du skal få din mette.

Vogge du ligg i er snart for trang,

du kavar og skrik og vil op i mit fang.

Tung er du, tung - og natta er lang

for den som må bysse ein bytting.

Du er ikkje barnet mit,

men eitt som er på meg tvinga.

Mit barn var lite og vent og blidt

og vermde så mjukt mot bringa.

Alla som ser deg, gir meg det råd

at eg burde plaga deg, lugge og slå,

så vart du vel henta, så kunne eg få

tilbake det barnet eg miste.

Bysse bytting stor og stygg

- sjå ikkje såleis på meg.

Eg skal ikkje slå deg, ver du trygg,

og ingen ska ta deg frå meg.

Den andre er kvarmanns gull der han er,

men $d u$, du er hata av alle her,

så trengst det da vist at eg har deg kjoer.

- No trur eg du endeleg sovnar.

Gjennom å lese diktet med et barn i armene gestalter skuespilleren et av kristendommens mest kjente visuelle og fromhetsmessige motiver, nemlig Maria med barnet. Maria med barnet inngår tradisjonelt $\mathrm{i}$ 
en inkarnasjonsteologisk fortelling hvor Jesusbarnet og Maria danner en kroppslig og relasjonell ramme rundt den kristne gudens menneskekropp. Altertavler, statuer og malerier av Maria med barnet snakker ikke bare verbalt om Guds menneskebliven, men gjør performativt Guds menneskebliven i en form som er direkte overførbar til allmenne menneskelige erfaringer: Slik alle mennesker blir født av en kvinne, ble Gud født av en kvinne. Slik alle mennesker har en mor, hadde Gud en mor. Slik alle mennesker en gang har vært barn, var Gud et barn.

Når Goksøyr leser diktet på Nationaltheatrets scene, sammenstilles to elementer:

1) Diktet, skrevet i første person entall, fremføres av et menneske som lever med Downs syndrom. Det skjer slik en performativ sammenstilling mellom personen i diktet og personen som fremstiller diktet.

2) Denne performative kroppen spiller en morskropp ved at Goksøyr bærer en dukke i favnen. Fremføringen kan leses som en gestaltning i kropp og ord av en «Jomfru Maria med Downs syndrom» som bærer «Jesusbarnet med Downs syndrom» i armene sine.

Men Goksøyr («Maria») synger ingen lovsang hvor Gud takkes, slik vi finner hos Lukas (Luk 1, 47-55), men en alternativ og menneskelig voggesang - diktet «Voggesang for ein bytting».

Goksøyrs fremstilling destabiliserer den inkarnasjonsteologiske og folkelige fromhetsmessige narrative og visuelle koblingen mellom generelle menneskelige mødre og Gudsmoderen, menneskelige barn og Jesusbarnet. For det barnet som trer frem i gestaltningen, er ikke et universelt barn eller et barn som formidler en presumptiv universell glede over moderskapet. Diktet «Voggesang for ein bytting» er en vond tekst. Barnet som beskrives i diktet, bryter med forståelsen av hvordan et barn skal være og oppføre seg. Prisen som betales for bruddet med normaliteten, er at barnet av omgivelsene (og av moren selv) omtales som «stygt», «troll», «du kavar og skrik». Ja, bruddet er så radikalt at selve relasjonen står på spill, ettersom det eksisterende barnet ifølge diktet ikke er morens sanne barn, men «eitt som er på meg tvinga». Forestillingen om 
det «sanne» barnet er hos diktets jeg-person konstituert av alt det som det eksisterende barnet ikke er, nemlig «lite og vent og blidt». Ifølge morens stemme i diktet er summen av disse karakteristikkene at barnet ikke er menneskelig, men «en bytting», det vil si at det tilhører de underjordiske. Umenneskeliggjøringen av barnet legitimerer omgivelsenes fysiske vold mot det annerledes barnet: «Alla som ser deg, gir meg det råd at eg burde plaga deg, lugge og slå». Jeg-personen i diktet går så langt som å omtale barnet som bryter med normaliteten, som «hata av alle her», og i siste vers gjentar hun trusselen om fysisk vold, selv om den ledsages av en forsikring fra moren («ver du trygg») om at den ikke (i hvert fall i kveld) skal bli til virkelighet.

I Goksøyrs fremføring blir barnets uforståelighet som «vanlig» barn performativt forvandlet fra å handle om generell nattevåk og kolikk til å handle om fortidens og samtidens diskriminering og avhumanisering av mennesker som lever med Downs syndrom. Bruddet med forventningen om normalitet er derfor ikke knyttet til moderskapets allmenne slit. Noen mennesker - både fødte og ufødte - rammes særlig og på en spesifikk måte av at de bryter med samfunnets forestillinger om normalitet. Det å kalle noen et «barn» tilsier ikke at vedkommende hører inn under en naturgitt, universell kategori, men er et resultat av en diskursiv forhandling om hva som skal kunne kalles et barn. Diktet er et in medias res innblikk i forhandlingene om barnets menneskestatus, sett gjennom diktets ulike stemmer (morens og morens gjengivelse av omgivelsene). Slik viser diktet at det barnet som er annerledes - eksempelvis ved å ha Downs syndrom - i vår kultur står fare i for å bli umenneskliggjort og bli et legitimt objekt for vold. «Skuespiller», «alle», «moderen» eller «barnet» er diskursive kategorier, ikke statiske. Bak og i forkant av disse tilsynelatende nøytrale begrepene finnes det seleksjonsmekanismer som allerede har avgjort hvem som passer inn i kategoriene «skuespiller» og «barnet». Et avgjørende forhold for disse seleksjonskriteriene er i hvilken grad de ulike karakterene makter å innordne seg i en forestilling om normalitet, eksempelvis kognitivt funksjonsnivå. Goksøyr - forstått som en altertavle som viser Maria med Jesusbarnet - kan leses som en avsløring av «moderskapet» og «barnet» som begreper som på ingen måte kan sies å utgjøre nøytrale, naturlige eller universelle kategorier. 
Goksøyr sin fremføring er i seg selv et sterkt uttrykk for hvordan mennesker som lever med Downs syndrom, kan være kunstnere. Uttrykket trenger selvsagt ingen ekklesiologisk tolkning - det hviler på sin egen kunstneriske integritet. Men som ethvert annet menneskelig uttrykk er det dypest sett hermeneutisk åpent og derfor tilgjengelig for tolkninger som går på utsiden av og overskrider avsenderens opprinnelige intensjon, kontekst og horisont. En ekklesiologisk tolkning av Goksøyrs uttrykk altså som en iscenesettelse av Maria med Jesusbarnet - tilfører uttrykket en idéhistorisk dimensjon der den vestlige kulturens kanskje mest kjente uttrykk for mor-barn-kjærligheten (Maria og Jesusbarnet) forskyves fra å være en representasjon av generelle menneskelige erfaringer til å bli en avsløring av at det «allmenne» og barnet som noe «naturlig» ikke er nettopp det. En ikke-diskursiv forståelse av «barn» og det «allmenne» er uttrykk for en privilegert posisjon hvor menneskelig mangfold er begrenset til ikke å inkludere erfaringen av potensiell umenneskeliggjøring, det vil si det å ende opp i kategorien «bytting». I stedet for å godta en slik avgrensning av hva menneskelig mangfold kan romme, insisterer uttrykket på at hvis Maria skal representere det allmennmenneskelige, så må denne forståelsen også romme dem hvis menneskelighet blir trukket i tvil av omgivelsene. Goksøyr gestaltet som Maria kan leses som en forhandling av hvem som kan tilhøre kategorien «menneske». Denne forhandlingen skjer gjennom bruken av et av den empiriske kirkens mest kjente motiver for religiøs (visuell og narrativ) representasjonen av moderskap, å være barn og menneskelighet (Maria med barnet). Bruddet med denne representasjonen skjer ved at morens kjærlighet til barnet er vaklende, og barnets status som «barn» er utvetydig. Slik skjer det et brudd med den tradisjonelle Maria-skikkelsen (som en udelt kjærlig mor) og Jesus (som utvetydig identifieres som «menneskebarnet»). Bruddet synliggjør at bak eller i forkant av - etableringen av «alle», «barn», «moren» og «Messias» som nøytrale og naturlige kategorier, foregår det en seleksjon av hvem som kan tilhøre disse kategoriene, og hvem som er «bytting» eller «barn».

Dette bruddet inviterer til videre hermeneutisk refleksjon som fortsetter inn i de bibelske tekstene, som en disability-kritisk hermeneutikk: Hvis Goksøyr er moder Maria, hvilken sønn (Sønn) trer da frem i lesningen av tekstene om Jesus? Jesu Messias-identitet er da ikke kun gjenstand 
for en forhandling mellom hans tilhengere (i evangeliene kalt «disiplene») og motstandere («fariseere») og alle midt imellom («folkemengden»). Forhandlingen om hvilken sønn (Sønn) Jesus er, er diskursivt formet av allerede fastlagte kulturelle kategorier. Hvis Guds menneskeliggjøring gjennom inkarnasjonen virkelig skal speile menneskelig mangfold, må Jesusbarnet dele kår som har blitt mennesker med kognitive funksjonsnedsettelser til del, nemlig en risiko for å ikke å bli gjenkjent som det de har potensiale for. Hvis et disability-kritisk perspektiv brukes for å spørre hva som står på spill i spørsmålet om Jesus blir gjenkjent som «Gud sønn» eller en «omreisende predikant som hevder å være Guds sønn», åpnes det opp et større og mer risikabelt landskap enn det som vanlige skisseres i kristologien. Det som står på spill, er ikke valget mellom å bli gjenkjent som «Guds sønn» eller «omreisende predikant som hevder å være Guds sønn», men mellom å være menneske eller ikke-menneske, det vil si en «bytting». Hvis påstanden i Nikenum om at Jesus er fullt menneske og Gud på samme tid, er sann, må Jesu menneskelighet også romme muligheten for å bli - lik barnet $\mathrm{i}$ «Voggesang for en bytting» - utpekt som ikke-menneske. Skal kristologiens forståelse av menneskelighet romme menneskelig mangfold, handler det som står på spill i spørsmålet om Jesu to naturer, ikke bare om frykten for at Jesu menneskelighet skal bli «sugd» opp i hans guddommelighet, slik kirker med en monofysittisk kristologi lærer. ${ }^{2}$ Det som står på spill i tonaturlæren, er like mye at Jesu menneskelighet også innebærer en sårbarhet for at denne menneskeligheten diskursivt blir konvertert til umenneskelighet, fordi hans måte å være menneske på ikke samsvarer med den personen som trer frem som et forståelig menneske. Forhandlingen i bibeltekstene (og videre kristologiske diskusjoner) er derfor ikke bare om Jesu guddommelighet kontra hans menneskelighet, men om hans menneskelighet kontra umenneskelighet. Lest med Goksøyr («Maria») som hermeneutisk linse kan Jesu offentlige virke, slik evangeliene beskriver det, forstås som en forhandling mellom det å være forstått som en Guds sønn eller som en bytting, det vil si en 
som settes utenfor menneskefellesskapet. Korsfestelsesscenen er i dette perspektivet en utløsning av den volden som inntreffer når grensen for hva normaliteten kan romme, krysses. Jesus går i løpet av sitt tre år lange offentlige virke fra å være «barn» til å bli «bytting». Han er sønnen (til Maria) som hevder å være Sønnen (til Gud), som ender opp som ikkesønn («Korfest ham! Korsfest ham!»). Men i motsetning til i diktet av Moren Vesaas skjer det i påskens fortelling ingen tilbakeholdelse av trusselen om volden som denne endringen av sosial kategori legitimerer. På Golgata fullbyrder Jesu omgivelser (fariseerne og de skriftlærde) rådene de ifølge kulturen er blitt gitt om hvordan byttinger skal behandles: «eg burde plaga deg, lugge og slå».

\section{Disability-ekklesiologien og den desentrerte kirke}

Som nevnt innledningsvis er en disability-teologi rik på ekklesiologiske refleksjoner. Utviklingen av en disability-sensitiv desentrert kirke skjer ikke i et ekklesiologisk vakuum. Jeg skal i det følgende velge ut to aspekter ved disability-ekklesiologien og drøfte lesningen av Goksøyr som et eksempel på desentrert disability-ekklesiologi opp mot disse. Disse to aspektene er for det første integrering som mål for disability-ekklesiologien og for det andre syn på liturgisk autonomi hos mennesker med funksjonsnedsettelser. Hensikten med lesningen er å vise hvordan en utvidelse av forståelsen av hva som anses som egnede empiriske felt for disability-ekklesiologien, kan bidra til teoretisk nyskapning. En destabilisering av vante forestillinger om hvordan man innenfor empirisk orienterte disability-ekklesiologier leter når man ser etter steder som egner seg for feltstudier for empirisk ekklesiologi, kan bidra til å utvide hvilke menneskelige erfaringer som legges til grunn i disability-ekklesiologien.

\section{Inkludering}

Sentralt i ulike disability-ekklesiologier står tanken om den menneskerettslige og teologiske nødvendigheten av integrering av mennesker med ulike former for kognitiv funksjonsnedsettelse i menigheten. Ulike 
teologer legger vekten ulike steder. Hos Inger Marie Lid (Lid, 2017, 2016) er integrering skrevet frem først og fremst som et menneskerettslig perspektiv. Ved å plassere mennesker med funksjonsnedsettelse på fysiske steder utenfor storsamfunnets arenaer blir tilrettelegging av rom uttrykk for i hvilken grad medborgerskap skal være knyttet til et spesifikt funksjonsnivå. Som Lid skriver: «For 40 år siden var det sjelden å se en rampe og et toalett for rullestolbrukere, i dag er disse konkrete uttrykkene for tilgjengelighet en del av fellesrommene og signaliserer inkludering og likeverd» (Lid, 2017, s. 52). Hvis kirken vil være en folkekirke, så må kirkens folk også inkludere mennesker med funksjonsnedsettelser (Lid, 2016). Kirkerommet blir i dette perspektivet et eksempel på slike fellesrom som må være reelt tilgjengelige for hele folket. En empirisk analyse av hva som må til for at inkludering skal kunne skje, er beskrevet i Torill Edøys En kirke for alle - Funksjonshemmede i kirken (2000), basert på Edøys intervjuer med mennesker som både har et aktivt forhold til kirken og kristne organisasjoner, og som lever med ulike former for funksjonsnedsettelser.

I Thomas Reynolds' (2008) og Nancy Eieslands (1994) ekklesiologiske refleksjoner står også integrering og inkludering i sentrum, sett fra bibelfaglige perspektiver. Reynolds argumenterer bibelteologisk for hvorfor kirkelige praksiser må tilrettelegges for alle funksjonsnivåer. Hvis kirken (ifølge Paulus) er en kropp (1. Kor 12) som trenger alle sine deler for å fungere, så betyr dette at «excluding one member of the body of Christ mars its image» (Reynolds, 2018s, s. 237). Den enheten som inkludering av mennesker med ulike funksjonsnivåer i kirkelige praksiser uttrykker, gjenfinnes i kroppen som bibelsk kjernemetafor for hva kirken er. Hos Eiesland finnes liknende begrunnelser, også med henvisning til 1. Kor 12. Hun betoner sterkere enn Reynolds den kontinuerlige omvendelsen til å tro på Gud som en funksjonshemmet Gud. Dette er ikke kun en oppgave for mennesker som selv lever med funkjonsnedsettelse for å skape en

3 Inger Marie Lids ulike arbeider har ulike fokus. Det er derfor ikke rettferdig mot mangfoldet i hennes arbeid å plassere henne utelukkende innenfor et menneskerettighetsperspektiv på inkludering. I doktorgradsarbeidet fra 2012 arbeider hun også med en systematisk-teologisk drøfting av funksjonsnedsettelse (se særlig Lid, 2012, s. 172-156). Dette er utdypet i Lid (2017) «Livets mangfold som gave og oppgave» (i Holte, Jensen \& Mjaaland (Red.) (2017), Skapelsesnåde festskrift til Svein Aage Christoffersen. Oslo: Novus forlag). 
symbolsk kontekstuell representasjon, men en kollektiv oppgave for alle kirkens medlemmer.

Integrering i storsamfunnets rom, symboler og praksiser som en strategi for å skape rettferdighet for mennesker som lever funksjonsnedsettelser, er uten tvil en svært effektiv og viktig metode for å skape endring. Dette er også en strategi man kan gjenkjenne fra mange andre grupper som har erfart ekskludering, som skeive eller kvinnelige teologers kamp for ordinasjon. Lids, Reynolds' og Eieslands ekklesiologiske arbeider er derfor metoder for å skape rettferdighet i praksis. I lys av dette kapitlets forsøk på å skrive frem en desentert disability-ekklesiologi blir det derfor et spørsmål hva forholdet er mellom et disability-perspektiv på den desentrerte kirken og integrering som tema i disability-ekklesiologien.

En forskjell er at det skjer en destabilisering av hvilke menneskelige erfaringer som gjøres relevante for ekklesiologisk forskning. Mens tradisjonell disability-ekkesiologi tar utgangspunkt i kirken som empirisk størrelse, og vurderer i hvilken grad slike steder er åsteder for inkludering eller ekskludering av mennesker med funksjonsnedsettelser, gjør en disability-sensitiv desentrert ekklesiologi prinsipielt hele verden relevant for ekklesiologisk forskning. Denne utvidelsen av det epistemologiske grunnlaget for disability-ekklesiologien har både styrker og svakheter som er tett sammenknyttet. Utvidelsen av hvilke livserfaringer og praksiser som er relevante for disability-ekklesiologi, avstår fra å forstå spørsmålet om rettferdighet bare som et spørsmål om å oppnå deltakelse i de kirkelige praksisens som rent empirisk finnes En desentert disability-ekklesiologi tolker spørsmålet om integrering i et utopisk perspektiv; forskeren kan aldri vite hvor kirken er. Kirken blir til - også rent empirisk - gjennom en tolkning av det allmenne i et ekklesiologisk perspektiv. En desentert ekklesiologisk tenkning tilfører derfor tradisjonell disability-ekklesiologi et kirkekritisk perspektiv og åpner for en ekklesiologisk refleksjon, også i møte med de menneskene og de praksisene som ikke rommes av det som empirisk sett kalles kirke. Denne kirkekritikken handler ikke bare om kritikk av manglende rullestolramper eller ableistiske metaforer, men også om hvilke livserfaringer og praksiser som regnes som relevante for det «kirkelige». Integrering handler i den desentrerte disability-ekklesiologien om å integrere andre livserfaringer i ekklesiologien, ikke bare om 
å integrere mennesker med nedsatte funksjonsevner i den synlige empiriske kirken. Teologisk innebærer utvidelsen av ekklesiologiens epistemologiske grunnlag et krav om å gjøre første trosartikkel - Gud har skapt verden - til ekklesiologiens utgangspunkt. Verden er ekklesiologiens subjekt. Disability-ekklesiologiens engasjement for rettferdighet tar derfor utgangspunkt $\mathrm{i}$ alle måter mennesker med nedsatte funksjonsevne finnes i verden på, ikke kun de måtene som sammenfaller med eksisterende kirkelige uttrykk.

En svakhet ved utvidelsen av disability-ekklesiologien ligger tett opptil dens styrker. Det er grunn til å spørre om en teologisk tolkning av fenomener som anses seg som rent sekulære, kan føre til at denne tolkningen oppleves som kolonialistisk. Det er en hårfin balanse mellom hermeneutisk appropriasjon og inkludering, fordi en intensjon og måten den lander hos mottaker på, aldri er overlappende. Det å forsvare en desentert ekklesiologisk tenkning innebærer å være forankret i en forståelse av at teologisk arbeid er et spørsmål om hermeneutikk, ikke ontologi (Tanner, 1997). Man må fastholde: Goksøyr har stått på Nationaltheatrets scene og fremført et dikt. Tolkningen av hendelsen som en ekklesiologisk hendelse, er forskerens, ikke hennes. Denne tolkningen endrer ikke det rent sekulære særpreget ved hendelsen; den er ikke ekklesiologisk interessant fordi den nesten er en kirke. En fremføring på Nasjonalteateret er ikke kirke. Det ikke-kirkelige og sekulære særpreget ved hendelsen må fastholdes: Uten dette vil verdens integritet krenkes ved at den kristeliggjøres. Når dette skjer, gis den andre trosartikkelen (Om Jesus Kristus) en epistemologisk forrang foran de to andre trosartiklene. Det er nettopp fordi hendelsen ikke er en del av den synlige empirisk kirken at hendelsen er ekklesiologisk interessant. Det å tolke noe som ekklesiologisk er ikke det samme som å si at hendelsen «egentlig» er en kirke, men at dette er en av de potensielt uendelige måtene å tolke den gudsskapte verdenen på.

\section{Syn på autonomi hos mennesker med kognitiv funksjonsnedsettelse}

Det er imidlertid et punkt hvor en disability-sensitiv desentert kirke og en disability-tenkning om kirkelige praksiser utfordrer hverandre på mer 
direkte vis. Dette handler om synet på autonomi, særlig når det er koblet til deltakelse i kirkelige praksiser. Teologen og presten Ådne Njå har gjennom flere år feiret gudstjeneste sammen med en speidergruppe bestående av voksne med kognitiv funksjonsnedsettelse, hvor speiderne har fungert som ministranter (Njå, 2017).

Til grunn for Njås fortolkning av speidernes rolle ligger en vilje til å skape en teologi som også kan romme mennesker med radikale kognitive funksjonsnedsettelser. En slik teologi kan ikke forutsette eller praktisere et syn på menneskene som handlende og vurderende, men må fastholde mennesket som mottakende. En måte å praktisere dette menneskesynet på i liturgien er å nedtone betydningen av enkeltpersonen (ministrant, prest) som selvstendig aktør; det å være menneske er å være mottaker av Guds nåde, verd, ord og gester formidlet gjennom en tradisjon.

Det er all grunn til å være enig med Njå i at vestlig filosofisk tenkning har gjort det autonome subjektet til et udiskutabelt sentrum. Han har uten tvil rett $\mathrm{i}$ at dette menneskesynet er problematisk for mennesker med både uten, med eller med radikalt nedsatt funksjonsnedsettelse. Sårbarhet - i alle former - er en allmenn erfaring. Likevel er det problematisk når de praktiske konsekvensene av en teologi som vil inkludere mennesker med funksjonsnedsettelse, paradoksalt nok blir en måte å minimere det kreative og selvstendige bidraget til mennesker med kognitive funksjonsnedsettelser på. For Njå er det viktig at speidergruppens liturgiske deltakelse på ingen måte skal være «presterende og selvutfoldende» (s. 15). Det er svært viktig at speiderne har de samme oppgavene hver gang, slik at «ingenting fremsto som prestasjoner», og at man «nedtoner det personlige, selvvalgte og kreative» (s. 15). Njå observerer at speiderne selv er opptatt av egen fremtreden i liturgien, noe som kommer til syne i form av spørsmålene «Var det bra? Var jeg bra?» (s. 8). Njå tolker slike spørsmål som behov for «selvbekreftelse, som de fleste i vår humanistiske kultur er dominert av» (s. 8). Selv om Njå anerkjenner at slike behov for tilbakemelding egentlig er uttrykk for «behovet for aksept og kjærlighet (s. 8)», så er det viktig for ham å veilede dem til en forståelse av at deltakelse handler om en «mer dyptgripende personbekreftelse» (s. 8) som «betyr å miste seg selv inn i aksepterende og nådefulle relasjoner» (s. 8). 
I møte med de praktisk-liturgiske konsekvensene av Njås teologi er det grunn til å spørre hvorfor oppgjøret med en problematisk arv skal plasseres hos dem som er blitt rammet av den. For dem som på grunn av kjønn eller klassetilhørighet historisk sett aldri har hatt muligheten til å stå frem i verden som handlende subjekter, er en forståelse av mennesket som primært mottakere - enten av Guds nåde eller av samfunnets diskurser - ikke nødvendigvis frigjørende (Benhabib, 1992, s. 214). Innenfor feministteologien formulerer Valerie Saiving presist hvordan menneskets samfunnsmessige vilkår i verden og teologiens syn på mennesket må ses i sammenheng. Saiving viser i den klassiske feministteologiske artikkelen «The human situation: a feminine view» (1960) at diskusjonen om hvilken posisjon mennesket gis i gudstjenesten, ikke kan ses uavhengig av hvilken posisjon disse menneskene har i samfunnet for øvrig. Saivings perspektiv er feministteologisk. Hun viser at synd som aktiv handling betyr ulike ting fordi kvinner og menn historisk sett har blitt tillagt ulike muligheter for handling i verdenen utenfor liturgien. Så lenge kvinner ikke primært blir oppfordret til å være handlende subjekter, kan kvinners synd ikke primært forstås som handling, men heller som unnlatelse av handling.

En applikasjon av dette perspektivet på Njå tvinger frem et spørsmål om hvem som har tilgang til å handle kreativt, selvvalgt og individuelt både $i$ og utenfor liturgien. Når tilgangen på synlighet og subjekt-status utenfor liturgien er så ulik for presten og mennesker med nedsatt kognitivt funksjonsnivå, kan man da stille det samme kravet til at liturgisk deltakelse skal være «ikke-presterende», «ikke-kreativ», «ikke-selvvalgt»? Njås liturgiske disability-praksis står i fare for å gjøre funksjonshemmedes deltakelse i kirkelige praksiser til «edle syndebukker» som gjennom ikke-prestasjonsorientert og «forsvinnende» nærvær skal gjøre opp for hundre år med vestlig autonomisentrert filosofi. I denne tenkningen tar den ikke-funksjonshemmede presten på seg byrden av å være gudstjenestens leder, som $i$ praksis er synlig, individuell og representativ i kraft av å være prest og predikant. Innenfor en liturgisk tenkning rundt deltakelsen til mennesker med kognitiv funksjonsnedsettelse må man ta inn over seg at liturgi aldri feires i et maktmessig, synlighetsmessig eller representativt vakuum, men er et sted der makt utfordres eller fastholdes. Uten denne innsikten kan en slik liturgisk tenkning stå i fare for i 
praksis å befeste og videreføre den asymmetrien mellom mennesker med og uten kognitiv funksjonsnedsettelse som Njå gjennom sin liturgiske praksis ønsker å øve motstand mot. Er den kirkelig ansatte uten funksjonsnedsettelse sin tiltro til egen udiskutable rett til å avfeie personer med funksjonsnedsettelse sine behov for tilbakemelding som et utslag for «selvbekreftelse» et uttrykk for at noen mennesker anses som «B-mennesker», som trenger tolkning av sitt eget nærvær og deltakelse for å delta i gudstjenesten på «rett måte»?

Det er derfor en direkte motsetning mellom Njås perspektiv og den ekklesiologiske lesningen jeg har gjort av Goksøyr. Goksøyr deltar i kraft av å være profesjonelt utdannet skuespiller. Hun «forsvinner» ikke, men fremstår heller som et kreativt individ som kommer med et unikt bidrag som ikke kan reduseres til noe hun har blitt fortalt at hun skal gjøre, enten av en liturgisk tradisjon, en prest eller noen andre. Å stå på Nationaltheatrets scene er i aller høyeste grad en prestasjon. Svært mange mennesker som lever uten kognitiv funksjonsnedsettelse ville ikke ha de profesjonelle eller eksistensielle forutsetningene for å gjennomføre en slik kunstnerisk prestasjon. Hvorfor skal ikke en ekklesiologisk tenkning om funksjonsnedsettelse også kunne romme denne type aktørskap og oppvisning av autonomi? Hvorfor skal søkningen etter aktørskap være et mindre filosofisk (og etisk) legitimt prosjekt for mennesker som lever med kognitiv funksjonsnedsettelse, all den tid mennesker med ikkekognitive funksjonsnedsettelser har tilgang til svært mange statsinitierte plattformer (utdanning) eller sivilsamfunnsmessige plattformer (litteratur, kunst, aktivisme, sosiale medier) for å skape og fremme menneskers autonomi og kreativitet? Å forstå vektlegging av behovet for aktørskap og autonomi som kun en videreføring en filosofisk arv som i for stor grad vektlegger subjektivitet, overser de sosiale og politiske maktmessige kontekstene som kirkelige praksiser skjer i. I stedet kan man snu på forholdet mellom arv og funksjonsnivå, og hevde at en disability-sensitiv lesning av kirkelige praksiser må ha et særlig blikk for - og legge til rette for - det kreative, selvstendige bidraget til mennesker med kognitive funksjonsnedsettelser. En måte å gjøre dette på er å lage slike muligheter i liturgien. En annen måte er å utvikle teologiske perspektiver - eksempelvis ideen om kirken som desentrert - som gjør de kreative uttrykkene til mennesker 
med kognitive funksjonsnedsettelser (som Goksøyr på Nathonaltheatret) relevante for ekklesiologien som helhet.

\section{Oppsummering}

Dette kapitlet er et bidrag til disability-ekklesiologien. Bidragets hensikt er ikke å beskrive hvordan arenaer som menigheter eller øvrige kirkelige praksiser inkluderer eller ekskluderer mennesker med funksjonsnedsettelser. Slike studier er i seg selv verdifulle og fører uten tvil til økt bevissthet og endring, slik at kirkelige praksiser kan bli arenaer for reell inkludering av mennesker som lever med ulike former for funksjonsnedsettelse.

Dette kapitlets hensikt har vært å vise at disability-ekklesiologien er i samsvar med teoretisk og metodisk ekklesiologisk nyskapende arbeid, Trygve Wyllers desentrerte kirke. Dette grepet åpner opp for å tolke sekulære praksiser - som en teaterforestilling - som relevante for ekklesiologisk teoridannelse. Jeg har løftet frem et eksempel på en slik hendelse som kan forstås som en desentrert kirke, nemlig Marte Wexelsens Goksøyrs fremføring av «Voggesang for ein bytting» på Nationaltheatrets scene. En tolkning av Goksøyr som Maria med Jesusbarnet kan berike disability-ekklesiologien gjennom både å bekrefte og utvide mer tradisjonelle bidrag.

\section{Referanser}

Edøy, T. (2000). En kirke for alle - funksjonshemmede i kirken. Oslo: Verbum.

Eiesland, N. (1994). The disabled God: Toward a liberatory theology of disability. Nashville, TN: Abington Press.

Benhabib, S. (1992). Situating the self. Gender, community and postmodernism in contemporary ethics. New York: Routledge.

Fulkerson, M. M. (2007). Places of redemption. Theology for a wordly church. Oxford, England: Oxford University Press.

Healy, N. M. (2000). Church, world, and the Christian life: Practical-prophetic ecclesiology. Cambridge, England: Cambridge University Press.

Ideström, J. (2015). Ecclesiology in the trenches: Theory and method under construction. Church of Sweden Research series, nr. 10. Eugene, OR: Pickwick Publications. 
Lid, I. M. (2012). Likeverdig tilgjengelighet? En drøfting av menneskesyn og funksjonshemning med vekt på etiske problemstillinger knyttet til universell utforming, mangfold og deltagelse. (Doktoravhandling). Oslo: Universitet i Oslo.

Lid, I. M. (2016). Hva må kirken vite om funksjonshemning? Nytt norsk kirkeblad, 5, 7-15.

Lid, I. M. (2017a). Medborgerskap i spennet mellom ekskludering og inkludering. I I. M. Lid og T. Wyller (Red.), Rom og etikk. Fortellinger om ambivalens. Oslo: Cappelen Damm Akademisk.

Lid, I. M. (2017b). Livets mangfold som gave og oppgave. I Holte, Jensen \& Mjaaland (Red.), Skapelsesnåde - festskrift til Svein Aage Christoffersen. Oslo: Novus forlag.

Lid, I. M. \& Bergsjø, L. O. (2017). Kontekstuell teologi. I I. M. Lid (Red.), Diakoni og velferdsstat - utvikling av en diakonal praksis i samspill med myndigheter, sivilsamfunn og borgere. Oslo: Gyldendal.

Njå, Å. (2017). De makalause og en makeløs Gud. Norsk teologisk tidsskrift, 6(3). https://doi.org/10.18261/issn.1893-0271-2017-03-05

Reynolds, T. (2008). Vulnerable communion. A theology of disability of hospitality. Grand Rapids, MI: Brazos Press.

Scharen, C. (2011). Explorations in ethnography and ecclesiology. Cambridge, England: William B. Eerdmans Publishing Company.

Ward, P. (2012). Perspectives on ethnography and ecclesiology. Cambridge, England: William B. Eerdmans Publishing Company.

Wyller, T. \& Heimbrock, H.-G. (2019). Challenging ecclesiological tradition. International Academy for Practical Theology Conference Series, 1(1), 129-137.

Wyller, T. (2017). Mellom Lampedusa og Luther. I S. Holte, R. Jensen \& M. T. Mjaaland (Red.), Skapelsesnåde - festskrift til Svein Aage Christoffersen (s. 407423). Oslo: Novus forlag.

Tanner, K. (1997): Theories of culture. A new agenda for theology. Minneapolis, MN: Fortress Press.

Saiving, V. G. (1960). The human situation: A feminine view. The Journal of Religion, 4o(2), 100-112. https://doi.org/10.1086/485231 



\title{
Imago Dei og kroppsliggjort væren: En funksjonshemmingsteologi i lys av Thomas Aquinas
}

\section{Therese Marie Ignacio Bjørnaas \\ Dronning Mauds Minne Høgskole}

\begin{abstract}
Theologians and philosophers have historically privileged the faculty of rationality in their exegesis of what it means to be created in the image of God. They have argued that we were made in God's image when we were endowed with a rational soul. This argument is contested by contemporary disability theologians. They argue that by equating the imago Dei with the faculty of rationality Christian theology effectively strips people with cognitive disabilities of their human rights. It justifies elevating the cognitively able over the cognitively disabled in the same way that it justifies elevating the human species over other species. In this article, I will first show that the contemporary Western conviction that ability and independence are normal while disability and dependence are deviant owes much to definitions of the human first proposed by Augustine of Hippo, Thomas Aquinas, and Immanuel Kant. I will then propose that Aquinas himself offers us a way out of these destructive binarisms. He defines the imago Dei as an embodied soul, an imperfectly intelligent substance that can fulfill its destiny only if it receives the support of society and the intervention of God's grace. Aquinas's theology of embodiment does not merely expose false assumptions about ability and disability; it compels us to appreciate the radical dependency and vulnerability of human nature.
\end{abstract}

Keywords: theological anthropology, Thomas Aquinas, disability theology, intellectual disability, rationality, imago Dei, embodiment

Sitering av denne artikkelen: Bjørnaas, T. M. I. (2020). Imago Dei og kroppsliggjort væren: En funksjonshemmingsteologi i lys av Thomas Aquinas. I I. M. Lid \& A. R. Solevåg (Red.), Religiøst medborgerskap: Funksjonshemming, likeverd og menneskesyn (Kap. 13, s. 269-286). Oslo: Cappelen Damm Akademisk. https://doi.org/10.23865/noasp.10o.ch13

Lisens: CC BY-NC-ND 4.0. 


\section{Innledning}

Eugenikken - eller rasehygienen - altså studiet av hvordan mennesket kan forbedres gjennom seleksjon, oppsto på slutten av 180o-tallet, men de moralske spørsmålene som den reiser, er fortsatt relevante. Forestillingen om at visse menneskelige trekk eller egenskaper gjør individer mindre verdt, er aktuelle blant flere forskere i dag. Etikeren Peter Singer hevder for eksempel at mennesker som mangler evnen til selvbevissthet og selvkontroll, ikke er fullverdige mennesker (Singer, 1995, s. 20-22). Den medisinske etikeren John Harris hevder at siden det er i samfunnets interesse å opprettholde en produktiv arbeidsstyrke, vil det være galt å sette barn med funksjonsnedsettelse til verden (Harris, 1992). James Watson, medoppdager av DNA-molekylet, har uttalt at «[v]i aksepterer at folk flest ikke ønsker et barn med Downs syndrom. Du må nesten være gal for å si at du ønsker et slikt barn, siden et slikt barn ikke har noen fremtid» (sitert i Kafer, 2013, s. 3). ${ }^{1}$

Spørsmålet om genetisk informasjon er høyst aktuelt i en tid der prenatal testing kan påvise så å si enhver funksjonsnedsettelse eller sykdom, slik at et økende antall mennesker må forholde seg til det etiske dilemmaet som følger med abort. John Swinton påpeker at mens vestlige samfunn har vist økende bekymring for mangelen på sosial rettferdighet som tilbys mennesker med funksjonsnedsettelse, så er det fortsatt «en underlig taushet omkring implikasjonene som vitenskap og forskning om genetikk kan ha for mennesker med funksjonshemming» (Swinton, 2007, s. 1-2). Mange mennesker med funksjonsnedsettelse er dypt bekymret med tanke på $ø$ kende genetisk testing. Slik testing, skriver Linda Ward, «sender sterke signaler om mennesker med funksjonsnedsettelse sin grunnleggende rett til liv» (Ward, 2002, s. 187-200). Tobin Siebers hevder at dagens samfunn ser på mennesker med funksjonsnedsettelse som mindre verdt enn andre. Han påpeker at «verdien av et menneskeliv først blir et tema når et menneske har en funksjonshemming», og han konkluderer med at funksjonsevne eller prestasjonsevne som ideologi kan få oss til å tenke at «det er bedre å være død enn funksjonshemmet» (Siebers, 2010, s. 274). 
Det overordnede spørsmålet synes å være følgende: Omfatter retten til liv ethvert menneske, eller reduseres denne retten proporsjonalt med at evnene våre minker? I vestlig filosofi er det lang tradisjon for å knytte det egentlige menneskelige til rasjonalitet. Vestlige samfunn synes å verdsette egenskaper vi kan assosiere med rasjonalitet, slik som autonomi og selvstendighet. I vårt vestlige tankesett er det å være menneske ofte definert av det som Giorgio Agamben (2013) kaller en "operativ ontologi», altså at menneskets væren og eksistens er fullstendig slått sammen med aktivitet. Den moderne forestillingen om eksistens dikterer at fullverdige mennesker er «operative» og «effektive» nok til å forholde seg til den moderne verdenens direktiver. Denne oppfatningen av «det normale mennesket» som et rasjonelt, uavhengig og selvtilstrekkelig vesen som kan bidra til samfunnet, er bakgrunnen for det ubehaget funksjonsnedsettelse - og da særlig kognitiv funksjonsnedsettelse - er forbundet med i vestlige samfunn.

I denne artikkelen drøfter jeg hvorvidt definisjonen av et normalt menneske som et rasjonelt menneske er påvirket og formet av den teologiske doktrinen om mennesket skapt i Guds bilde, den såkalte imago Dei-doktrinen. I den første delen oppsummerer jeg tolkninger av denne doktrinen. Her vil jeg presentere menneskesynet til Augustin av Hippo, Thomas Aquinas og Immanuel Kant for å vise hvordan disse tre filosofene har bidratt til den moderne forståelsen av mennesket. I den andre delen anvender jeg middelalderteologen Thomas Aquinas sin kroppsliggjorte teologi for å bryte med forestillingen om normalitet som noe rasjonelt. Ved hjelp av Aquinas' teologi vil jeg argumentere for et syn der mennesket blir forstått som relasjonelt og avhengig - og derfor har et grunnleggende behov for Guds nåde.

\section{Del 1: Det rasjonelle gudsbildet}

Tradisjonelt trekker kristen teologi følgende sentrale konklusjoner om imago Dei:

1) Siden mennesket er den eneste arten som ble skapt i Guds bilde, så er vi den eneste arten med egenskaper som representerer dette bildet. 
2) I vestlig kristen teologi har tendensen vært å tolke våre rasjonelle og kognitive evner som gudbilledlighetens viktigste markør.

3) Rasjonalitet er knyttet utelukkende til tanken/sinnet, og dermed oppfattes den som noe immaterielt - den ikke-kroppslige sjelen.

4) Sjelen vår er imago Dei og forholder seg til Gud som en rent åndelig substans.

Det menneskelige ligger i den rasjonelle sjelen - en sjel som er eller burde være frikoplet fra kroppslige følelser og ha evnen til å se objektivt på den eksterne verdenen gjennom universelle egenskaper som er gudgitte for alle mennesker. Målet med en slik forståelse er å etablere et egalitært samfunn gjennom rasjonell visshet. Vår rasjonelle evne, som alle har til felles, leder oss frem til et korpus av objektiv, feilfri kunnskap og dermed til den ultimate sannheten, som er sannheten om Gud. Dette er saligheten og derfor målet med livet. For å se nærmere på denne forståelsen vil jeg gjøre rede for hvordan Augustin, Aquinas og Kant vurderer det menneskelige.

\section{Augustin av Hippo}

Kirkelæreren Augustin (d. 430) betrakter menneskelig liv i form av kropp og sjel, men ser kroppen som en lavere og mindreverdig enhet. I hans verk De libero arbitrio, der han drøfter menneskets frie vilje, ser vi at han er tydelig påvirket av Platon. Platon hevdet at siden den fysiske verdenen er i konstant endring, kan det ikke finnes noen eviggyldig kunnskap om den. Den eneste eviggyldige kunnskapen kommer fra den uforanderlige verdenen av ideer. Augustin forestiller seg en kontrast mellom den tenkende sjelen og den sansende kroppen. Den materielle verdenen vi sanser, består av flyktige og foranderlige sannheter, mens den immaterielle verdenen, som er fornuftbasert, er permanent og inneholder evige realiteter (Augustin, 1993, bd. II, s. 6-7).

Når han anvender dette på den menneskelige natur, hevder Augustin at mennesker hører til mellom den immaterielle og den materielle verdenen. Vi har en rasjonell sjel som er en immateriell, udødelig og fullkommen enhet, og som har tilhold i en materiell, dødelig og ufullkommen 
kropp. Sjelens fremste evne - intellektet - kan fundere over den evige sannhet, og derfor er det kun den rasjonelle sjelen som kan kvalifisere som imago Dei: «Mennesket ble skapt i bildet av Ham som skapte ham, ikke gjennom legemet, men gjennom den rasjonelle sjelen, der sannheten om Gud eksisterer» (Augustin, 2002, 12.7.12). Her ser vi Platons innflytelse på Augustin. Platon mente at fordi vi har materielle kropper, er vi delvis dyr, og fordi vi har en immateriell sjel, er vi delvis guddommelige. Målet er å bli kvitt vår kroppslige natur, for da blir vi som Gud, vårt ultimate mål (Platon, 1970, s. 189-190). Augustin anvender Platons teori og ser på mennesket som sammensatt av en fullkommen rasjonell sjel hvor evig sannhet finnes, og med en ufullkommen følelsesmessige kropp som hindrer mennesket å finne denne sannheten. Målet for mennesket er derfor å avsverge det kroppslige.

I De Trinitate, der han skriver om Gud som treenig, utvikler Augustin sin forståelse av imago Dei. Han skiller mellom kroppen, som er «det ytre mennesket», og sjelen, som er «det indre mennesket». Det indre mennesket kjennetegnes som rasjonelt og intellektuelt. Intellektet kjenner universelle ideer, men er ikke i stand til å favne dem fordi kroppen forvrenger dem. Augustin hevder at det er vår plikt som mennesker å omfavne et intellektuelt liv (Augustin, 1993, bd. II, s. 8-9). For ham ligger vårt forhold til Gud fremfor alt i den rasjonelle sjelen eller vårt intellekt, og derfor sies det at vi kun er i gudsbildet når vi erkjenner Gud (Augustin, 2002, 12.3.3). I Augustins teori må mennesket, for å erkjenne, gå fra det ytre til det indre, fra et lavere nivå til et høyere, hvor kroppen gir et lavere nivå av kunnskap og sjelen gi et høyere nivå. Først når vi kommer til sjelens «indre menneske», møter vi gudsbildet, ifølge hans teologi. Dette tilsier at den viktigste veien til Gud er i oss selv. Ifølge Augustin oppdager vi Gud ved hjelp av en «innoverreise».

Augustins forståelse av imago Dei som det ulegemliggjorte intellektet finner vi igjen i ideologien om moderne individualisme. Feministteologen Catherine LaCugna har påpekt denne sammenhengen. Hun mener at ideen om at veien til Gud ligger i det innovervendte selvet, har styrket den moderne individualismen på bekostning av sosial samvittighet. Siden vestlig tradisjon har vektlagt introspeksjon og refleksjon om selvet, er det vanskelig for oss å se det i menneskets vesen som er sosialt, felles og 
«vendt mot hverandre» (LaCugna, 1991, s. 274). Ved å hevde at egen eksistens er den første sannheten et menneske kjenner, etablerer Augustin førstepersonssynspunktet som grunnlaget for søken etter sannhet. Det innovervendte i selvbevisstheten som Augustin identifiserer som imago Dei, står i kontrast til den verdens utovervendthet som denne selvbevisstheten er avhengig av for sin eksistens.

For Augustin er målet vårt som imago Dei å bruke våre universelle evner til å være autonome og uavhengige aktører i den sosiale ordenen. Dette involverer å skille seg fra det kroppslige, fordi målet er å få vår immaterielle enhet - vårt imago Dei - til å skinne klart. Med andre ord, mens vi i nåtid er en enhet av kropp og sjel, er vårt imago Dei en ulegemliggjort sjel som vi bør strebe mot. På grunn av denne innovervendte veien mot Gud og sannhet hevder teologen Colin E. Gunton at Augustins identifisering av imago Dei står «i kjernen av de problemer» som er typiske for moderne individualisme (Gunton, 1997, s. 92).

\section{Thomas Aquinas}

I middelalderen overtok Thomas Aquinas (1225-1274) Augustins definisjon av imago Dei som grunnleggende. Aquinas var teolog og filosof innenfor dominikanerordenen. I sitt hovedverk Summa Theologiae (1265-1274) hevder Aquinas at mens alle skapninger bærer «en slags likhet med Gud», er det «bare mennesker som rasjonelle skapninger som likner Gud i sin natur» (1946, bd. I, Spørsmål (Q) 93, Artikkel (a) 6). Et sentralt element i skolastisk antropologi er en definisjon av sjelen som setter den instrumentelle fornuftsevnen over alt annet. Aquinas er slik sett elev av Aristoteles heller enn av Platon. Han hevder ikke, slik Augustin gjør, at man kan få kunnskap gjennom introspeksjon. Aquinas mener at man tilegner seg kunnskap, inkludert kunnskap om Gud, først og fremst fra sanseinntrykk. Likevel definerer Aquinas gudsbildet, altså sjelen, som «en individuell substans med intellektuell natur» (Aquinas, 1946, III.Q.16, a.12). Han oppfatter imago Dei som sjelens høyeste evne, den immaterielle substansen som mennesket erkjenner gjennom: «Det er nødvendig å si at det som all intellektuell virksomhet springer ut av, det vi kaller menneskets sjel, både er immaterielt og består i seg selv» (Aquinas, 1951, 
Artikkel (a) 9, Argument (a) 19). Siden intellektet er en substans som består i seg selv, er menneskets erkjennende intellekt uforgjengelig.

Det er sjelen som vinner kunnskap om Gud og leder til Gud, skriver Aquinas: «Sjelen er selv et bilde av Gud og leder direkte til ham» (Aquinas, bd. I, Distinksjon (d) 3, Spørsmål (Q) 4, Artikkel (a) 4, sitert i Merriell, 1990). Siden det å være i gudsbildet er «selve sjelens natur, som er felles for alle mennesker», er de som bærer gudsbildet, intellektuelle vesener som aktivt forstår og elsker Gud, for ved å gjøre dette etterlikner de Gud i Guds egen evne til å forstå seg selv (Aquinas, 1946, I.Q.93, a.4). Aquinas hevder uttrykkelig at det er gjennom gudsbildet i oss vi har et helt spesielt forhold til Gud, som er vårt endelige mål. Den rasjonelle sjel er skapt i Guds bilde på den måten at den kan anvende fornuft for å forstå Gud som sitt formål (1946, I.Q.93, a.7). Han forklarer: «Gudsbildet finnes i sjelen når sjelen vender seg mot Gud, eller har en natur som tillater sjelen å vende seg mot Gud» (1946, I.Q.93, a.8).

Likeens hevder Aquinas i De Veritate at når et menneske erkjenner Gud, blir hun mer lik Gud: «Når tanken erkjenner Gud, blir den formet av Gud, slik enhver som erkjenner, tar del i det som blir erkjent» (Aquinas, 1953, Spørsmål (Q) 10, Artikkel (a) 7). Vi er i Guds bilde når vi aktivt tar del i Guds bilde, og denne delaktigheten finner sted når mennesket erkjenner. For Aquinas har derfor mennesket en naturlig evne til å håndtere alt det rasjonelle, og denne medfødte evnen gjør oss til intelligente vesener med en uendelig kunnskapstørst. Vår naturlige drift mot kunnskap faller ikke til ro før vi har erkjent den ytterste sannhet, som er Gud. Derfor er en intelligent skapnings endelige mål å skue Guds vesen, kjent som saligheten.

Aquinas sin teologi er blitt møtt med sterke motforestillinger innenfor fagfeltet «tverrfaglig funksjonshemmingsforskning» nettopp for sin orientering mot menneskene som intelligente vesener. For eksempel hevder filosofen Peter Byrne at Aquinas sin fremstilling av menneskets mål som så sterkt knyttet til en rasjonell erkjennelse av Gud, underforstått leder til en forståelse av at mennesker som har manglende intellekt, er ute av stand til å nå frelse. Byrne konkluderer med at Aquinas’ teologi dermed er «skrevet som om det ikke finnes mennesker med kognitiv funksjonsnedsettelse, eller som om de ikke er fullverdige mennesker» (Byrne, 200o, s. 147). 
Andre funksjonshemmingsteologer har påpekt noe av det samme. Hans S. Reinders er skarp i sin kritikk: «Han [Aquinas] spør om gudsbildet bare finnes i intellektet, eller om det er andre egenskaper eller kvaliteter der gudsbildet kunne ha tilhold. Men han besvarer dette spørsmålet negativt; vesener uten rasjonell evne kan ikke reflektere dette bildet» (Reinders, 1999, s. 228-9). Molly Haslam fastslår at det ifølge Aquinas er kun intellektuelle skapninger som besitter gudsbildet på en korrekt eller fullstendig måte (Haslam, 2012, s. 97). Både Byrne, Reinders og Haslam hevder at i Aquinas' teologi må mennesker med kognitiv funksjonsnedsettelse mangle eller delvis mangle imago Dei, siden rasjonelle evner er gudsbildets essensielle markør. Dette tilsier at Aquinas er en utfordrende tenker å bruke når man vil argumentere for at mennesker med kognitiv funksjonsnedsettelse er fullverdige mennesker. I andre del av kapitlet vil jeg likevel våge å tolke noen av hans teologiske teser om den kroppsliggjorte sjelen, og foreslå en annen lesning enn Byrne, Reinders og Haslam gjør.

\section{Immanuel Kant}

I opplysningstiden fant ideen om «menneskelig verdighet basert på fornuftsevne» sin fullstendige form. Immanuel Kant (1724-1804) hevder at vår fornuftsevne gir oss en enestående status i kosmos. Som Augustin definerer han kroppen som en upålitelig kilde til ren forstandsmessig kunnskap. For ham er det vårt intellekt, og da spesielt vår fornuftsevne, som definerer oss som mennesker, fordi fornuften er grunnlaget for den objektive moralloven. Denne moralloven bestemmes uavhengig av materielle forhold, og ikke minst er den uavhengig av menneskers identitet som empiriske subjekt. Kant anser fornuftsevnen som grunnlaget for hva det betyr å være menneske (Kant, 1964, s. 98-99).

Kant konstruerer sin antropologi på grunnlag av menneskets objektive rasjonelle evner. Det er a priori et system i vår tenkning som leder oss mot en universell og objektiv sannhet, der mennesket, i kraft av å være et fornuftsvesen, besitter evnen til å handle i samsvar med den universelle loven. Det er det fornuftige mennesket som er grunnlaget for tanken om det kategoriske imperativet (prinsippet for moralsk handling), det vil si at mennesket er både skapere og tilhengere av den universelle moralloven. 
Vi handler etter lover som vi har pålagt oss selv, noe som gjør oss til autonome vesener. Derfor er det å være autonom utelukkende knyttet til det å være et fornuftsvesen. Som «selvlovgivere» skiller vi oss fra dyrene, som ikke stiller spørsmål ved sine handlinger. Evnen til autonomi er derfor grunnlaget for menneskelig verdighet. Det er denne evnen som løfter oss over alle andre skapninger. Kant sier at «[m]enneskets verdighet består nettopp i evnen til å lage universelle lover, selv om dette bare er på betingelse av at mennesket også er underlagt de lovene det lager» (Kant, 1964, s. 107).

For Kant blir mennesket kilden til sannhet: «En annen kan ikke tilføre visshet til et menneske, det kommer av mennesket selv» (Kant, 1978, s. 95). Hans filosofi fremholder individualisme som kjernen i hva det betyr å være menneske. Moralske lover er selvpålagt og beskytter individuell autonomi. Når vi søker sannhet, er vi kun avhengig av vår egen fornuft. Minimumskravet for en handling er at handlingen er i samsvar med vår egen fornuft og dermed er moralloven noe som skal kunne universaliseres, det vil si være lik for alle mennesker. Derfor står det individuelle subjektet alltid i sentrum. Kant oppsummerer det skarpt:

Opplysning er når mennesket kommer ut av sin selvpålagte umodenhet. Umodenhet er mangel på evne til å bruke egen forstålse uten å bli ledet av andre. Denne umodenheten er selvpålagt dersom årsaken ikke er mangel på forståelse, men mangel på beslutningskraft og mot til å bruke den uten veiledning av en annen. (Kant, 2009, s. 1)

Rasjonell tenkning har sin plass i individuell bevissthet. Derfor er sannhet, den universelle moralloven, grunngitt i den absolutte verdien til alle mennesker som intelligente vesener. For Kant er vi derfor likeverdige mennesker kun i kraft av å være fornuftsvesener.

\section{Oppsummering: konstruksjonen av det normale mennesket}

Forståelsen av mennesket som et rasjonelt vesen går altså tilbake til Platon og Aristoteles, via senantikken og middelalderen til opplysningstidens individualisme og videre til modernismen. Forskere innenfor tverrfaglig 
funksjonshemingsforskning poengterer at funksjonshemming er konstruert som en unormal tilstand fordi godene som det moderne liberale samfunn verdsetter, er goder som mennesker med funksjonsnedsettelse ser ut til å mangle. Rosemarie Garland-Thomson definerer funksjonshemming som «ethvert avvik fra en ubestemt fysisk og funksjonell norm» hvor «normen blir nøytral i samfunn som er opprettet for å imøtekomme den» (Garland-Thomson, 1997, s. 24). Ifølge henne konstrueres funksjonsnedsettelse som en avvikende tilstand fordi det påstås at den hemmer de egenskapene som vestlige samfunn setter høyest, det vil si selvmestring og autonom handling. Hun mener at mennesker med funksjonsnedsettelse oppfattes som mindreverdige og unormale nettopp fordi de ikke når opp til «forestillingen som mennesker i et liberalt samfunn forstår og organiserer sine identiteter rundt» (s. 47). For henne er ikke funksjonshemming en tilstand i seg selv, men en fordom som kommer fra det å «sammenlikne individuelle kropper med usagte, men avgjørende normer» (s. 7). Konstruksjonen av funksjonshemming som en tilstand av avhengighet og uselvstendighet korresponderer med en tilsvarende konstruksjon av det å være funksjonsfrisk som en tilstand av uavhengighet og selvkontroll. I dette paradigmet tildeler man full moralsk status til mennesker kun dersom de besitter slike evner, og man blir forledet til å se på mennesker som mangler (eller tilsynelatende mangler) disse evnene, som mindreverdige.

I Vesten i dag er mennesket ofte definert ut fra kognitive egenskaper. Dette reduserer verdien av og verdigheten til en person med kognitiv funksjonshemming (Yong, 2007, s. 173). Slike personer er ifølge Thomas E. Reynolds eksempler på mennesker «som reduserer rasjonell objektivitet» (Reynolds, 2008, s. 85). Når vi definerer normalitet med begrepene autonomi og selvkontroll, står vi i fare for å definere mennesker med kognitiv funksjonsnedsettelse som unormale. For å håndtere sine liv trenger mennesker med kognitiv funksjonsnedsettelse i større grad assistanse fra et støttende nettverk av familie, venner og profesjonelle omsorgspersoner. Noen mennesker med kognitiv funksjonsnedsettelse trenger hjelp til å kle på seg, spise, vaske seg eller gå på toalettet. Dermed kan disse menneskenes virkelighet være fullstendig i strid med idealet om det moderne selvstyrte selvet. Av den grunn, hevder Nancy Eiesland, blir mennesker 
med funksjonsnedsettelse ofte i sin alminnelighet oppfattet som «mindre intelligente, mindre i stand til å ta de 'rette' avgjørelsene, mindre 'realistiske', mindre logiske og mindre egenstyrte enn de som ikke er funksjonshemmet» (Eiesland, 1994, s. 25).

For å utvikle en teologisk antropologi som også anser mennesker med kognitiv funksjonshemming som fullverdige uttrykk for Guds bilde, må vi bryte med definisjonen av normalitet i form av egenskaper som rasjonalitet, uavhengighet og selvstendighet.

\section{Del 2: Aquinas' kroppsliggjorte teologi}

Som vi har sett, avviser ikke Aquinas sin teologi rasjonelle egenskaper som et avgjørende særtrekk ved menneskenaturen. Tvert imot kjennetegnes mennesket som art nettopp av intellektet. I likhet med Aristoteles mener Aquinas at det som utgjør menneskers særegne natur, er tenkeevnen, den funksjonen eller evnen som utgjør det man kaller menneskets rasjonelle sjel. Denne forståelsen av mennesket kan antyde at besittelsen av intellektuelle evner er det som definerer mennesket. Jeg hevder likevel at Aquinas ikke går så langt. Han avviker fra denne forestillingen fordi hans erkjennelsesteoretiske grunnsyn er at ingenting finnes i intellektet som ikke først var i sansene. Aquinas bryter med det dualistiske grunnsynet til Platon og erklærer menneskene som «fornuftige dyr». Følgelig inkorporerer Aquinas' teologi noe som vestlige subjektivitetsteorier (for eksempel Kant sin) stort sett ignorerer, nemlig den materielle kroppen.

Aquinas forklarer skapelsens grunnleggende gudsavhengighet ved hjelp av den neoplatonske ideen exitus-reditus, altså at alt kommer fra Gud når det blir født, og returnerer til Gud når det dør. Intet i universet eksisterer selvstendig; alt eksisterer ved å ta del $i$ Guds væren. Aquinas hevder at mennesker tar del i både en guddommelig og en animalsk eksistens (Aquinas, 2001, Leksjon (L) 2, Nummer (N) 70). Gud er den første beveger og årsak til alt som eksisterer, og derfor «har alt som eksisterer, med unntak av Gud, ikke egen væren, men finner sin væren gjennom deltakelse i Gud»(Aquinas, 1946, I.Q.44, a.1). Det å ta del i Guds natur er ikke å være identisk med Gud, men å delta i Gud på en ufullstendig måte. Således mener Aquinas at mennesket har potensial til å bli forent med 
Gud - å bli ett med Gud. Dette potensialet, som er iboende i alle mennesker, er vårt mål (telos) som bærere av imago Dei.

Aquinas henter en metode fra den protovitenskapelige metodologien hos Aristoteles, som er mer orientert mot det empiriske - det som kan oppfattes med sansene. Dette søkelyset på det sansbare lar ham betrakte menneskets kroppslige natur med større nysgjerrighet og alvor. Mens Aristoteles postulerer at objektet for vår erfaring er en sammensetning av stoff og form, anser Aquinas form som årsaken til stoff. Anvendt på menneskets væren er den substansielle formen den rasjonelle sjel. Ikke desto mindre må en form ha stoff for å eksistere. I menneskets tilfelle er stoffet kroppen (Aquinas, 1951, a.1.a.18). Aquinas konkluderer derfor med at sjelen er kroppens form, og at sjelen dermed realiserer seg gjennom den kroppen den gir form til (1946, I.Q.75, a.1). Således ser Aquinas mennesket som en sammensatt enhet av eksisterende immaterielle og forgjengelige materielle egenskaper - en åndelig eller spirituell sjel og et animalsk eller dyrisk legeme. Slik Aquinas-forskeren Eleonore Stump forklarer det, ser han sjelen som en «konfigurert konfigurator». Den er konfigurert på grunn av sin eksisterende form og sine immaterielle egenskaper, som intellekt og vilje, og den er konfigurator fordi den konfigurerer stoff, altså nettopp det som utgjør det hele mennesket (Stump, 2003, s. 201-2). Aquinas hevder at den rasjonale sjelen alltid er forent med kroppen, av samme årsak som at form alltid er forent med materie. Den rasjonale sjelen både mottar og produserer kunnskap sammen med kroppen.

Ifølge Gloria Schaab «forsøker Aquinas å løse kropp-sjel-dualismen ved å foreslå at sjelen er formen og substansen til kroppen og løfter kroppen til en spirituell væren» (Schaab, 2012, s. 40). For å være nøyaktig bekrefter Aquinas at imago Dei er den rasjonale sjel, men at den menneskelige væren ikke ligger utelukkende i sjelen, fordi menneskelig væren er en forent enhet av kropp og sjel. I denne tankegangen unngår Aquinas å stille intellektet opp mot sansene i en kappestrid om menneskelig kunnskap og forståelse. «Intellektets virkemåte», bemerker han fyndig, «har sin opprinnelse i de kroppslige sansene» (Aquinas, 1946, I.Q.78, a.4). Ved syndefallet ble vårt rene intellekt omformet til det som Aquinas kaller et «simpelt intellekt», og med det mener han at intellektet trenger kroppen for i det hele tatt å fungere slik et intellekt skal. 
Aquinas legger vekt på at kroppslige følelser og sanser setter i gang vår tenkning om og forståelse av sannhet. Sansekunnskap fungerer som materie, som intellektet former til intellektuell kunnskap. For Aquinas er det derfor slik at vi ikke trenger å bryte med vår animalske tilstand for å nå vårt menneskelige telos, vårt mål. Vi er tvert imot avhengige av den. Rasjonell aktivitet er dermed en kroppsliggjort aktivitet, og derfor kan vi konkludere med at vårt imago Dei ikke tilbakelegger veien til kunnskap i retning av Gud utelukkende langs en innadvendt og intellektuell vei; rasjonelle evner konstitueres av og foregår i de fysiske kroppene og i konkrete sosiale forhold. Den sannheten vi er ment å skulle oppdage, gjelder verdenen rundt oss så vel som verdenen inne i oss. Vårt indre gudsbilde er derfor skapt og formet av vårt samfunn. Rasjonalitet er en relasjonell egenskap; på egen hånd kan vi verken oppdage den guddommelige sannheten eller bildet av Gud i oss med tilstrekkelig ærbødighet. Enhver handling sjelen instruerer kroppen om å gjøre, er samhandling med våre omgivelser og potensielt med andre mennesker. Dermed er vi rasjonelle bare ved hjelp av kroppen vår og andre kropper. Mark D. Jordan sier at det for Aquinas er slik at «kroppsliggjorte sjeler lærer gjennom kropper og av andre kropper» (Jordan, 2017, s. 15).

\section{Aquinas og det rasjonelle}

Som vi har sett, finner vestlige intellektuelle som Watson, Singer og Rachels at mennesker med kognitive funksjonsnedsettelse mangler muligheten til å leve et «normalt liv», hvilket vil si et liv med autonomi og selvmestring. Vestlig ideologi betrakter ofte mennesker med kognitive funksjonsnedsettelse som avvikende, i den grad de kan være ute av stand til - eller oppfattes som ute av stand til - å tilfredsstille minimumsstandarden til en slik kompetanse. Men disse tenkerne overser at rasjonell tanke aldri er uavhengig av relasjoner og kropp. Som psykologen Kenneth J. Gergen presiserer:

Rasjonell tanke, intensjoner, erfaring, hukommelse og kreativitet kommer ikke før relasjonelt liv, men skapes i forhold med andre. De er ikke i sinnet - atskilt fra verden og fra menneskelige forhold - men kroppsliggjorte handlinger som er formet og vedvares innenfor disse relasjonene. (2009, s. 95) 
Marianne Hedlund peker på noe av det samme når hun sier at vi må forstå rasjonell tenkning som en i hovedsak relasjonell aktivitet. Da må vi forstå at en funksjonshemmet persons evne til rasjonell tenkning «[...] kan kreve andre premisser enn dem som ligger i nåværende sosiale forventninger og de aktuelle dominerende sosiale normer» (Hedlund, 2009, s. 12). Å være avhengig av noe eller noen vil for øvrig kun øke vår bevissthet om vår virkelige menneskelige natur som bærere av Guds bilde, og om hvor sammenknyttet alt liv er. Som Aquinas anfører: «Det hører til sjelens essens å være knyttet til en kropp» (Aquinas, 1946, I.Q.76, a.1). Det faktum at vi er kroppsliggjorte vesener, gjør at enhver menneskelig handling alltid er en samhandling, ikke en isolert handling. For Aquinas synes vår menneskelige essens å være relasjonell og avhengig.

Aquinas' antropologi avslører derfor at rasjonalitet og autonomi kun er illusjoner. Intet menneskelig vesen når opp til standarden som settes til det ideelle rasjonelle selvet. Som kroppsliggjort kan intet menneske tilfredsstille noe enhetlig ideal for menneskelig intelligens. Teologen Mary J. Iozzio fastslår at «intet menneske har oppnådd det som synes å være, og som vanligvis kalles uavhengighet, uten først å ha vært avhengig av andre» (Iozzio, 2005, s. 58). Vi blir jo alle født som hjelpeløse spedbarn. Relasjoner er grunnleggende viktige for prosessen som alle, uansett tilstand, avhenger av for å bli hele mennesker. Iozzio konkluderer med at «[g]jensidig avhengighet og forhold til andre er nødvendig for menneskelig blomstring, og for å ta vare på de grunnleggende fysiske, intellektuelle, emosjonelle, sosiale og åndelige behovene for vekst og utvikling som absolutt alle mennesker har» (s. 58). Reynolds formulerer det enkelt: «Jeg er fordi vi er» (Reynolds, 2008, s. 14).

Siden Aquinas betrakter rasjonalitet som en evne som stammer fra sansene, og som kun fungerer innen en kroppslig og interaktiv sosial kontekst, kan vi hevde i tråd med hans tenkning at mennesker med kognitive funksjonshemminger ikke er anormale, ettersom intet individ er fullstendig rasjonelt i og av seg selv. Aquinas påpeker at vi bærer gudsbildet i ufullkommenhet: «Dersom det eksisterte et perfekt bilde av Gud i våre sjeler, slik bildet av Sønnen er et perfekt bilde av Faderen, så ville vårt sinn straks kjenne Gud. Men bildet i vårt sinn er ufullkomment» (Aquinas, 1946, I.Q.88, a.3). 


\section{Imago Dei og Guds nåde}

Aquinas argumenterer for at mennesket er fullstendig avhengig av Gud og verden rundt seg for å realisere imago Dei. Dette bringer oss til et avgjørende aspekt av Aquinas' teologi; hans dialektiske tilnærming til kroppen. Mens vår rasjonelle sjel er forent med kroppen og dessuten totalt avhengig av den, så fungerer kroppen som et hinder på veien mot vårt endelige mål. Så lenge sjelen har bolig i en kropp, vil mennesket aldri kunne kjenne Gud slik Gud er, fordi Gud og endelig sannhet er noe rent spirituelt. Det vil si at vi aldri vil kjenne oss ordentlig hjemme før vi, som Gud og englene, kan erkjenne tingenes immaterielle essens. Sjelen bærer potensialet for å erkjenne sannheten, men fordi sjelen er en kroppsliggjort sjel, er vi totalt avhengige av Guds nåde for å realisere vårt iboende potensial. Aquinas sier videre at «[p]å grunn av det faktum at den [sjelen] er skapt i Guds bilde, er den mottakelig for nåde» (Aquinas, 1946, I-II.Q.113, a.10).

For Aquinas er Guds nåde villet og nødvendig for å føre mennesket til den oversanselige ordenen det ble skapt for. Gud rettferdiggjør oss og frelser oss fra synd ved å fylle oss med Guds helliggjørende ånd direkte i våre sjeler, gjennom Jesus Kristus. For Aquinas er nåde noe som kommer utenfra, og som når den først er blitt fylt i vår sjel av Gud, vil føre oss til vårt oversanselige mål. Fordi vår natur ble brakt i uorden av syndefallet, kan vi ikke realisere vår iboende godhet ved hjelp av våre iboende rasjonelle evner. Uten Guds nåde er vårt naturlige ønske om og evne til å kjenne Gud utilstrekkelig. Vi er fullstendig avhengig av Gud for å fullføre intensjonen i vår rasjonelle sjel.

Det er også en indre forbindelse mellom vårt naturlige gudsbilde og vårt nådegjorte eller fullkomne gudsbilde, ettersom nåde for Aquinas «bygger videre på naturen» (Schaab, 2012, s. 269). Michael Lapierre beskriver det siste som «et overordnet prinsipp som ligger inne i oss, og som løfter oss slik at vi kan utføre de gjerninger og handlinger som leder oss til vårt endelige mål, visjonen av Gud» (sitert i Schaab, 2012, s. 269). Enkelte teologer, spesielt John E. Sullivan og Karl Rahner, har hevdet at for Aquinas er vår naturlige tilstand allerede i nåden. Rahner fremholder at for Aquinas er alt det skapte allerede og alltid i nåde og forløst av Gud (Rahner, 1961). Dette minner meg om det paradoksale 
utsagnet fra Aquinas: «Nåde gjør naturen perfekt; den ødelegger den ikke» (Aquinas, 1946, bd. I.Q.1, a.9). Alt dette har betydning for et nytt perspektiv på menneskelig verdighet og den funksjonshemmede kroppen. Fra begynnelsen av «adopterte» Gud oss som sine barn, slik at Gud kunne gi oss evig liv (Aquinas, 1990, III.d.10.Q.2, a.1). Dermed synes det for Aquinas å være slik at det eneste nødvendige kravet til menneskelig realisering er å forbli i Guds nåde.

For Aquinas «er det Gud, ikke vår egen fortjeneste som frelser oss, og Guds godhet, ikke vår egen, som leger og helbreder», forklarer Paul Wadell (1992, s. 136). Vi er alle imago Dei, nettopp på grunn av vår evne til å nå vårt mål i Gud, gjennom nåden. Ifølge Aquinas kan ikke mennesket «oppnå det gode som er naturlig for [det]» (Aquinas, 1946, II.II.Q.109, a.2), selv om mennesket som imago Dei har en naturgitt evne til å kjenne Gud. Wadell tar tak i paradokset når han sier at for Aquinas «er nettopp det som er mest nødvendig for oss, også helt umulig for oss å oppnå» (Wadell, 2010, s. 435). Derfor kan ingen være mindre i Guds bilde eller mindre menneske på grunn av mangel på evner eller egenskaper. Trass i synspunktene fra Reinders, Byrne og Haslam vil jeg hevde at Aquinas ikke baserer sin forståelse av imago Dei utelukkende på rasjonell tenkning, men på vår relasjonelle kroppslighet og iboende mottakelighet for Guds nåde. Det er bare via Guds nåde at vår menneskelige natur kan bli fullkommen.

\section{Konklusjon}

For Aquinas er vi er alle ufullkomne mennesker som er fullstendig avhengige av Gud og andre rundt oss. Det er kun gjennom nåden at vi er imago $D e i$, og det er kun gjennom nåden at vi kan nå vårt menneskelige mål - å bli forent med Gud. Aquinas sin kroppsliggjorte teologi viser at mennesker er relasjonelle, sårbare og avhengige skapninger, noe som avslører at det moderne menneskesynet kun er en illusjon. Intet menneskelig vesen når opp til standarden som settes til det ideelle rasjonelle selv. Derfor kan ingen være mindre i Guds bilde eller mindre menneske på grunn av mangel på evner eller egenskaper. Aquinas utfordrer dermed den binære motsetningen som samfunnet konstruerer mellom funksjonshemmet og 
ikke-funksjonshemmet, og hans teologi kan imøtegå den modernistiske oppfatningen av menneskene som autonome og selvstyrte agenter med evne og forpliktelse til å handle ut fra en slik standard.

\section{Referanser}

Giorgio, A. (2013). Opus Dei: An archeology of duty (A. Kotsko, overs.). Stanford, CA: Stanford University Press.

Aquinas, T. (1946). Summa theologiae (Fathers of the English Dominican Province, overs.). London, England: Burns and Oates.

Aquinas, T. (1951). De anima (J. P. Rowan, overs.). Eugene, OR: Wipf \& Stock.

Aquinas, T. (1953). De veritate (J. V. McGlynn, overs.). Chicago, IL: Henry Regnery Company.

Aquinas, T. (2001). An exposition of the "On the Hebdomads" of Boethius. (Janice L. Schultz og Edward A. Synan, overs.) Washington, DC: The Catholic University of American Press.

Augustine. (1993). De libero arbitrio (T. Williams, overs.). Indianapolis, IN: Hackett Publishing Company.

Augustine. (2002). De trinitate (S. McKenna, overs.). Cambridge: Cambridge University Press.

Byrne, P. (2000). Philosophical and ethical problems in mental handicap. New York: Palgrave.

Eiesland, N. L. (1994). The disabled God: Toward a liberatory theology of disability. Nashville, TN: Abingdon Press.

Garland-Thomson, R. (1997). Extraordinary bodies: Figuring physical disability in American culture and literature. New York: Columbia University Press.

Gergen, K. J. (2009). Relational being: Beyond self and community. Oxford, England: Oxford University Press.

Gunton, C. E. (1997). The promise of trinitarian theology. London, England: T\&T Clark. Harris, J. (1992). Wonderwoman and Superman: The ethics of human biotechnology. Oxford, England: Oxford University Press.

Haslam, M. C. (2012). A constructive theology of intellectual disability: Human being as mutuality and response. New York: Fordham University Press.

Hedlund, M. (2009). Understandings of the disability concept: A complex and diverse concept. I C. A. Marshall, E. Kendall \& R. M. S. Grover (Red.), Disabilities: Insights from across fields and around the world. London, England: Praeger.

Iozzio, M. J. (2005). The writing on the wall ... Alzheimer's disease: A daughter's look at mom's faithful care of dad. Journal of Religion, Disability and Health, 8(2), 49-74. 
Jordan, M. D. (2017). Teaching bodies: A study of moral formation in the Summa of Thomas Aquinas. New York: Fordham University Press.

Kafer, A. (2013). Feminist, queer, crip. Bloomington, IN: Indiana University Press.

Kant, I. (1946). Groundwork of the metaphysics of morals (H. J. Paton, overs.). New York: Harper Torchbooks.

Kant, I. (1978). Anthropology from a pragmatic point of view (V. L. Dowdell, overs.). Carbondale, IL: Southern Illinois University Press.

Kant, I. (2009). An answer to the question: 'What is enlightenment?' (H. B. Nisbet, overs.). London, England: Penguin Books.

LaCugna, C. (1991). God for us: The Trinity and Christian life. New York: HarperCollins.

Merriell, J. (1990). To the image of the Trinity: A study of the development of Aquinas's teaching. Belgia: Pontifical Institute of Medieval Studies.

Platon. (1970). The law (T. J. Saunders, overs.). Middlesex, England: Penguin Books.

Rahner, K. (1961). Theological investigations. Baltimore, MD: Helicon Press.

Reinders, H. S. (1999). Receiving the gift of friendship: Profound disability, theological anthropology, and ethics. Chicago, IL: Carus Publishing Company.

Reynolds, T. E. (2008). Vulnerable communion: A theology of disability and hospitality. Grand Rapids, MI: Brazos Press.

Schaab, G. (2012). Trinity in relations: Creation, incarnation, and grace in an evolving cosmos. Winona, MN: Anselm Academic.

Siebers, T. (2010). Disability and the theory of complex embodiment: For identity politics in a new register. I L. J. Davis (Red.), Disability studies reader. London: Routledge.

Singer, P. (1995). Killing babies isn't always wrong. The Spectator, (16), 20-22.

Stanley, G. J. (2001). The matrix of Christian theology: The social god and the relational self: A trinitarian theology of the imago Dei. Louisville, KY: Westminster John Knox Press.

Stump, E. (2003). Aquinas. London, England: Routledge.

Swinton, J. (2007). Introduction. I J. Swinton \& B. Brock (Red.), Theology, disability and the new genetics: Why science needs the Church. London, England: T\&T Clark.

Wadell, P. (1992). Primacy of love: An introduction to the ethics of Thomas Aquinas. New York: Paulist Press.

Wadell, P. (2010). An itinerary to glory: How grace is embodied in the communion of charity. Studies in Christian Ethics, 23(4), 431-448.

Ward, L. (2002). Whose right to choose? The 'new' genetics, prenatal testing and people with learning disabilities. Critical Public Health, 12(2), 187-200.

Yong, A. (2007). Theology and Down syndrome: Reimagining disability in late modernity. Waco, TX: Baylor University Press. 


\section{Om forfatterne}

Knut Alfsvåg er professor i systematisk teologi ved Fakultet for teologi, diakoni og ledelsesfag ved VID vitenskapelige høgskole. Han var misjonsprest (NMS) i Japan 1986-1999, lærer i kirkehistorie ved Kobe Lutheran Theological Seminary fra 1989, og har vært tilknyttet MHS/ VID siden 1999. Han har blant annet arbeidet med gudsforståelse og modernitetskritikk.

Leonora Onarheim Bergsjø, $\mathrm{PhD}$, er forsker ved Det teologiske fakultet, Universitetet i Oslo. Hun er opptatt av hvordan vi bruker ulike medier til å forstå våre liv. I doktorgraden gjennomførte hun en teologiske-estetisk studie av eksistensielle og religiøse aspekter ved kunst, siden har hun jobbet med kirkerom og digitale medier.

Therese M. I. Bjørnaas er førsteamanuensis ved Seksjon for religion, livssyn og etikk ved Dronning Mauds Minne Høgskole. Hun har en PhD i systematisk teologi og filosofi fra Graduate Theological Union/University of California, Berkeley.

Anita Gjermestad er professor ved Fakultet for helsefag ved VID vitenskapelige høyskole, Sandnes. Gjermestad er utdannet vernepleier med $\mathrm{PhD}$ i spesialpedagogikk. Hun arbeider inne feltene funksjonshemmingsforskning og medborgerskap med vekt på utviklingshemming.

Gyrid Gunnes er utdannet religionsviter og teolog, og er ordinert prest i Den norske kirke. Hun arbeider med en doktoravhandling i diakoni om Kirkens Bymisjon ved VID vitenskapelige høgskole. Hennes forskningsinteresser er teologi og marginalitet, ekklesiologi, kjønn og performativitet.

Hans Morten Haugen er professor i internasjonal diakoni ved VID vitenskapelige høgskole. Han er statsviter og har doktorgrad i juss, begge 
fra Universitetet i Oslo. Forskningsinteresser er rettigheter, rettferdighet og inkluderende utvikling, noen ganger med empiri hentet fra kirkelige aktørers arbeid.

Gunnar Heiene var professor i etikk ved MF vitenskapelig høgskole fram til 1. juli 2020. Han har vært konsulent for internasjonale spørsmål i Mellomkirkelig Råd og medlem av Bioteknologirådet 2014-19. Han har særlig arbeidet med funksjonshemming og teologi, bioteknologi, internasjonal rettferdighet og globalisering.

Kari Jordheim er studieleder og førstelektor på diakoniprogrammet ved VID vitenskapelige høgskole. Hun har tidligere arbeidet som folkehøgskolelærer i Valdres, og som diakon i en menighet i Oslo sentrum. Jordheim har nå arbeidet med utvikling og gjennomføring av diakoniutdanningen gjennom mange år, og har i forskning og utviklingsarbeid særlig hatt fokus på hvordan diakoniens rolle er utformet og praktiseres innenfor kirken.

Inger Marie Lid er professor tilknyttet masterutdanning i Medborgerskap og samhandling ved VID vitenskapelige høyskole. Hun har doktorgrad i samtidsteologi og fra Universitetet i Oslo. Lids forskningsinteresser er tverrfaglig funksjonshemmingsforskning, etikk, medborgerskap og universell utforming.

Dmitry Lukash er høgskolelektor ved Fakultet for helsefag ved VID vitenskapelige høgskole. Han har master i religion og samfunn fra Universitetet i Oslo og arbeider med en doktoravhandling om norske omsorgstjenesteyteres oppfatninger av religiøsitet og religionspraksis til mennesker med utviklingshemming. Hans sentrale vitenskapelige interesser er religion, funksjonshemmingsforskning og menneskerettigheter.

Terese Bue Kessel er førsteamanuensis i praktisk teologi ved VID vitenskapelige høgskole. Hun har en doktorgrad i teologi. Hennes forskning er primært innenfor fagfeltet praktisk teologi med fokus på diakoni og sjelesorg i internasjonal kontekst, samt tema knyttet til Den norske 
kirkes trosopplæring. I doktoravhandlingen analyserer hun kvinners erfaring med kirken fra et kjønns- og diakonalt empowerment perspektiv.

Nora Simonhjell er PhD og arbeider som førsteamanuensis ved Institutt for nordisk og mediefag, Universitetet i Agder. Ho arbeider særleg med spørsmål om korleis skjønnlitteraturen tar opp tema som funksjonshemmingar og sjukdom.

Anna Rebecca Solevåg er professor i Det nye testamentet ved VID vitenskapelige høgskole og leder for Senter for misjon og globale studier. Hennes forskningsinteresser er ulike former for marginalisering og marginaliserte skikkelser i Bibelen og tidligkristen litteratur. Hun har blant annet forsket på kjønn, seksualitet, funksjonshemming og klasse i Det nye testamentet og i tidligkristne apokryfer og martyrfortellinger. 
